GILAT EZRA PITKOVSKY

\title{
PATENT AS A GENERATOR RATHER THAN INHIBITOR OF DRUG ACCESSIBILITY IN DEVELOPING COUNTRIES:
}

\section{A CRITICAL EXAMINATION OF INDIA'S PATENT MODEL}

\author{
LLM RESEARCH PAPER
}

LAWS 591

LAW FACULTY

VICTORIA UNIVERSITY OF WELLINGTON 
I would like to dedicate this work to the memory of my parents, Lihi and Meir Ezra 


\section{TABLE OF CONTENTS}

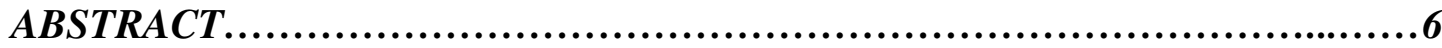

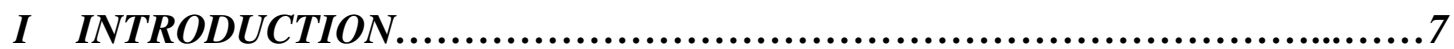

II PATENTING PHARMACEUTICALS - FURTHER OBSERVATIONS.........15

A. Does Patenting Pharmaceuticals Enable or Deter Drug Accessibility in Developing Countries..................................................15

1. Characteristics of the developing world.......................................15

2. North to south outlook.....................................................18

B. The Private - Public, Property- Health paradox in Patenting

Pharmaceuticals........................................................21

C. Patent as a Mediation Force ...........................................27

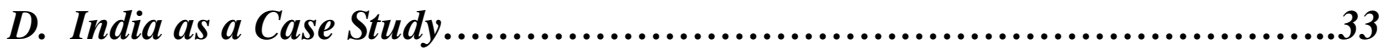

1. The socio-economic outlook ...............................................33

2. The Indian pharmaceutical industry..................................35

III PATENT AS A PRIME MOTIVATOR OF PHARMCEUTICAL INNOVATION...........................................................41

A. New Chemical Entities..............................................44

B. Incremental Pharmaceutical Innovation...................................51

IV GROWING INTO THE TRIPS - FROM GENERICS TO INNOVATION IN DEVELOPING COUNTRIES ...........................................58

A. The Great Rise of Generics..........................................58

B. Generics Fall and Innovation Rise ..................................68

V PATENT AS DRUGS COMMODITISING STARTEGY IN DEVELOPING

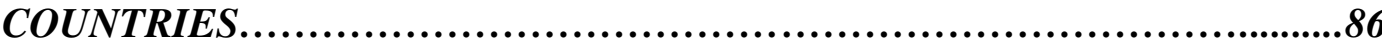

A. Commoditisation of Drugs Through International Technology Transfer: Application to Foreign Direct Investment.

1. The Indian pharmaceutical industry need of investment further observations. 
2. Foreign direct investment potential to intensify local production towards low cost patented drug marketplace.

3. The West propensity to the Indian pharmaceutical industry.

4. India as a host country of foreign direct investment.

B. Patent as a Leading Motivator of Foreign Direct Investment. 108

C. The Competition for Foreign Direct Investment:

India and China rivalry.

VI PATENTING INCREMENTAL PHARMACEUTICAL INNOVATION AS THE

FINAL STEP.

A. Patenting Pharmaceutical Incremental Innovation - a Prospect of a Better Healthcare 120

1. Price reducing competition 120

2. Tropical diseases research. 123

B. The paralysed Indian pharmaceutical patent mechanism 127

1. The paralysing fear of evergreening.

2. The un-patentable incremental pharmaceutical innovation.

(a) The legislative framework.

(b) The judicial commentary

(i) Novartis AG v Union of India.

(ii) Roche v Cipla Ltd.

3. Implications on the international spectrum: the compatibility with the TRIPS Agreement.

C. Forming a Balance: Endorsing Wider Compulsory Licensing Utilisation in India. 153

VII IT IS NOT ONLY LOCAL OBLIGATION: MAKING DRUGS ACCESSIBLE IN DEVELOPING COUNTRIES - A GLOBAL RESPONSIBILITY..........164

VIII CONCLUSION.

IX BIBLIOGRAPHY 


\section{ABSTRACT}

Patent's reputation as a constructive mechanism in the developing world was not a common notion. The prospect of utilising pharmaceutical patents to generate drug accessibility in developing countries did not seem possible. However, little credit was given to patents. Through motivating innovation, foreign investment, trade relations and industrialisation, patents can form a prowess pharmaceutical industry in the developing world. This thesis explores the possibility to increasing the availability of low cost drugs in emerging economies through patent enforcement. The analysis focuses on India as a case study. India has long been at the forefront of the developing world fight for low cost drugs markets. This stand once meant the exclusion of patent protection of pharmaceutical innovation and the formation of low cost copied generic drugs industry. However given developing countries' recent submissions to the international pressure to enforce patent protection on pharmaceutical innovations, it is time to re-examine the role patents play in developing countries, this time in the avenue of reducing drugs' pricing. India's current economy and the evolution of its pharmaceutical industry evolvement, make it as an exemplary case study to utilise patent to fulfil this end. Accordingly, the issue of widening the scope of patent protection in India to include pharmaceutical incremental innovation is examined. Notwithstanding the responsibility of India to endorse wider patent scope, legally and practically, the thesis does not ignore the moral obligation the developed world has towards India's poorer population to offer low cost drugs during the stages of its pharmaceutical industry emergence. The preliminary justification to conduct this observation is to show that patent is not only to answer the healthcare needs of the developed world population, but also the developing world. As such the thesis argues that India ought to stand at the forefront again, this time, demonstrating the potential within patent to establish low cost patented pharmaceuticals marketplace in developing countries.

\section{Statement on word length}

The paper has approximately 49,300 words excluding cover page, table of contents, footnotes and bibliography. 


\section{INTRODUCTION}

The Trade Related Intellectual Property Rights Agreement (TRIPS Agreement), obliges member countries of the World Trade Organisation: ${ }^{2}$ economically developed, developing and least developed countries, to offer patent protection for any technological innovation. ${ }^{3}$ This provision was expected to include protection of pharmaceutical innovations. By granting the patentee with market exclusivity over the invention for 20 years, ${ }^{4}$ patent avoids the risk of other firms in the protecting market, to copy the patented drug and compete with $i t^{5}$ as the generic industry exercised within developing countries prior to signing the TRIPS Agreement. ${ }^{6}$ From 2005 developing countries should have enforced patent protection for pharmaceutical inventions ${ }^{7}$ and once an interested party wishes to use the patented drug, a proper remuneration, as set by the patentee, needs to be paid.

Given that the cost of putting a drug on the market shelf can reach US $\$ 1$ Billion, ${ }^{8}$ the patented drug's cost is respectively rated highly to enable the pharmaceutical firm innovator to recoup its investment in the process of research and development. This prospect deepens the reliance of the pharmaceutical industry on patent enforcement because it promises market exclusivity and hinders the risk of generics price reducing competition. ${ }^{9}$ However, as much as the patent mechanism is needed to motivate the pharmaceutical industry to innovate, it is not preferred by

\footnotetext{
${ }^{1}$ Trade-Related Intellectual Property Rights Agreement (15 April 1994) 1869 UNTS 299 (1994) 33 ILM 81 [TRIPS Agreement].

${ }^{2}$ See "What is the WTO"? www.wto.org (accessed 17 October 2009).

${ }^{3}$ See TRIPS Agreement, above n 1, art 27(1). The Article specifically determines that all fields of technology are patentable and restrict any discriminative action towards one field of technology or the other.

${ }^{4}$ See TRIPS Agreement, above n 1, art 33.

${ }^{5}$ See TRIPS Agreement, above n 1, art 28.

${ }^{6}$ See Part IV A The Great Rise of Generics. For a definition of generic drugs see part III Patents as a Prime Motivator of Pharmaceutical Innovation.

${ }^{7}$ See TRIPS Agreement, above n 1, art 65. Generally according to Article 65(1), all member countries to the World Trade Organisation [WTO] had to enforce the TRIPS Agreement within a year, that is, until 1996. However, as ordered by Article 65(2), developing countries enjoyed an additional four years until 2000. Nevertheless, according to Article 65(4), if a developing country did not offer patent protection in the pharmaceutical technology field specifically in 1995, it had the opportunity to apply for patent enforcememnt in the marketplace no later than the year 2005.

${ }^{8}$ See Joseph A DiMasi, Henry G Grabowsky "The Cost of Biopharmaceutical R\&D: Is Biotech Different?" (2007) 28(4-5) Managerial and Decision Economics 469, 475.

${ }^{9}$ See James Bessen, Michael J Meurer Patent Failure: How Judges, Bureaucrats, and Lawyers Put Innovators at Risk (Princeton University Press, Princeton, 2008) 88-89.
} 
developing countries, for it maintains the status quo of the high prices of drugs, often resulting in sickness and deaths from treatable disease. ${ }^{10}$

Understandably, the propensity in the developing world for patent enforcement for pharmaceuticals is weak. However, the immense fear of high cost drugs has blinded the developing world from seeing the contribution of patent in boosting innovation and developments, which would eventually be able to offer an alternative to low cost drugs, other than generics. The thesis is concerned with this subject. Although generic production enables the poorer population of the world to enjoy low cost drugs, a contribution which is highly respected in the thesis, it does not answer the wider spectrum of healthcare in the developing world, a status which can be remedied through a wider enforcement of patent protection for pharmaceuticals. In other words, presenting the various layers of merits patent possesses, the thesis shows that although patent has a direct affect on the increase of the cost of drugs, it can encourage better healthcare in low cost drugs as well.

Needless to say healthcare is a major part of the vicious cycle of poverty, for lacking health means lacking proper education, social infrastructure and solid industrialisation which can lead directly again to poverty. Patent has attracted vast criticism as the wrong mechanism to be implemented in the developing world's pharmaceutical markets. Although this criticism is somewhat legitimate, it contains only one aspect of patent enforcement and dismisses the various elements that exist in its mechanism, which can improve the easy provision of drugs in the developing world, by strengthening the local innovative pharmaceutical industry.

The developing world has agreed to enforce patent protection on pharmaceutical innovations. Hence, finding a solution for the developing world's difficulty in accessing drugs ought to be located from within patent and not externally. As a property rights protector, patent is a great force of growth. Patent, as any other intellectual property rights, plays an important role in encouraging innovation,

\footnotetext{
${ }^{10}$ See generally Kalpana Chaturvedi, Joanna Chataway and David Wield "Policy, Markets and Knowledge: Strategic Synergies in Indian Pharmaceutical Firms"(2007) 19(5) Technology Analysis \& Strategic Management 565,565.
} 
industrial progress and technological growth. ${ }^{11}$ It also motivates investment, improves the quality of products, creates demand for a more skilled workforce, enables education opportunities and promotes economic growth. ${ }^{12}$ Therefore, if these elements are to be implemented in poorer yet relatively richer and advanced pharmaceutical industries such as in developing countries, the local innovation would advance and grow to offer extensive competition levels to ultimately reduce consumer prices. $^{13}$

In this respect it is important to mention that this thesis concerns the possibilities promised to the developing world, in comparison to the least developed world. The least developed world suffers from much lower socio - economic infrastructure stability compared to the developing world, and thus is not ready to absorb patent and benefit from its various merits. With weak functioning of legal institutions, non validation of property rights, ${ }^{14}$ unstable national currency, low communicative routes, unstable banking and insurance, low economic profitability, low quality products and weak resources to facilitate successful business relationships, ${ }^{15}$ least developed countries do not have the capacity to absorb patent protection and benefit from the introduction of new technologies to their marketplace. This conclusion is particularly true concerning the complex and costly pharmaceutical industry. For these reasons, least developed countries set a precondition to their joining the World Trade Organisation: that their enforcement of patent for pharmaceutical innovation would not start before the year $2016 .^{16}$

India, however, which is characterised as a developing country with low-middle income and which still suffers from high poverty rates, was not chosen randomly. The prime reason is the fact that India contains a high percentage of the world's poor population, which mostly relies on local products, and so there is a need to find a

\footnotetext{
${ }^{11}$ See Michael P Todaro, Stephen C Smith Economic Development (10ed, Pearson Education Limited, London, 2009) 2, 7.

${ }^{12}$ Ibid.

${ }^{13}$ See Margaret K Kyle, Anita M McGahan "Investments in Pharmaceuticals Before and After TRIPS" (Entrepreneurship and Innovation - Organizations, Institutions and Regions, Copenhagen, 2008) 1, 15, $17-18$.

${ }^{14}$ Todaro, Smith, above n 11, 67.

${ }^{15}$ Ibid.

${ }^{16}$ Declaration on the TRIPS Agreement and Public Health (14 November 2001) 755 WT/MIN (01)/DEC/W/2,41 I/L/M (2002) [Doha Declaration], art 7.
} 
home-based solution for drug accessibility. ${ }^{17}$ The other reasons rely on India's capacity to offer a solution for a low cost drug market within the framework of patent enforcement. India's exceptionally large consumer market size, ${ }^{18}$ its emergingindustrialised status, its domestic firms becoming multinationals, its growing scientific skills, its exposure to global markets and a relatively stable democracy ${ }^{19}$ make it as an ideal platform to examine the power within patent to reduce drug pricing through higher rates of investment and innovation.

The second reason for choosing India as a case study is the lacuna in its patent protection scope. Although India has constituted patent enforcement in every technological field since 2005, it is the only member country in the World Trade Organisation which excludes incremental innovation from patent protection scope by rigid restrictions on incremental innovation eligibility for protection. This reality not only attracts criticism for India's Patent Act compatibility to the TRIPS Agreement, ${ }^{20}$ but also from the pharmaceutical industry, which sees incremental innovation as its core level of innovation. $^{21}$

India's Government, therefore, made a choice not to utilise patent mechanism to advance its pharmaceutical industry and its economy, but to secure the low prices of drugs through the enlargement of the generic drugs pool. As long as incremental modified drugs innovation would be off patent protection, they would be legitimate for generic copying. Hence, instead of choosing to progress its limited innovative skills and try to find a solution from within its progress, India chose regression. It chose market failure and free riding, mistakenly configuring the latter as the only option to offer affordable drugs in the marketplace. Although having the needed social-economic features to encourage investment into its marketplace and despite having the needed skills to engage somewhat in pharmaceutical innovation, India will

\footnotetext{
${ }^{17}$ See generally Cheri Grace The Effect of Changing Intellectual Property on Pharmaceutical Industry Prospects in India and China: Considerations for Access to Medicines (prepared for the British Government's Department for International Development, 2004).

${ }^{18}$ Todaro, Smith, above n 11,15 .

${ }^{19}$ Ibid. See also Capgemini "Report Finds the Growth of New Multinationals from Emerging Markets Challenges Traditional Western Business Model" (20 June 2008) Press Release.

${ }^{20}$ See Part VI B 3 Implications on the international spectrum: the compatibility with the TRIPS Agreement.

${ }^{21}$ Ibid.
} 
not benefit from high rates of innovation ${ }^{22}$ or progression to the international pharmaceutical arena with all of its economic benefits.

One question needs to be asked - are generics preferable? Are they enough? The vast economic returns India has enjoyed from generic production can, on the one hand, answer its economic needs and, at the same time, offer lower priced drugs to the local population. Moreover, as long as the generic production is being practiced at the end of the patent term protection, it does not hurt the pharmaceutical industry market's exclusivity rights or the chances to recoup the costly invention. The answer however, despite the generic production benefits, is probably no for it does not answer wider healthcare needs as higher quality drugs as mentioned earlier.

But generics by themselves are not preferable over innovation. It can be a strong market force to reduce drug pricing; however it will not offer the ultimate solution for low cost drugs in India, as recently published by All-India Drug Action Network, a campaign group for Rational Drug Therapy and Policy. ${ }^{23}$ Moreover, it seems economically unreasonable that in a world which is dominated by intellectual property rights enforcement, the generic industry will be lucrative enough for the Indian pharmaceutical industry. Hence, as an alternative or even as an addition to generics' production, patent's encouragement of higher levels of local innovation can answer these aforementioned goals through the advancement of the local pharmaceutical productivity.

A larger scope of patent protection can make the difference for the Indian population as it will encourage high inflows of foreign direct investment to strengthen and advance the Indian limited innovative pharmaceutical industry skills. However, without a harmonised protection of intellectual property rights, this notion will wane. ${ }^{24}$ Without promising pharmaceutical multinationals low generic exposure, firms will not invest in the Indian pharmaceutical industry. ${ }^{25}$ Without proper market

\footnotetext{
${ }^{22}$ See generally Todaro, Smith, above n 11, 10.

${ }^{23}$ Drug Prices and Affordability www.ideas.repec.org (accessed 1 August 2009). All India Drug Action Network is a network of non governmental organisations aspired to increase accessesibility to essential drugs.

${ }^{24}$ See Todaro, Smith, above n 11, 6 .

${ }^{25}$ See Part V B Patent as a Leading Motivator of Foreign Direct Investment.
} 
exclusivity, pharmaceutical multinationals will not transfer their sophisticated technologies and open research facilities in India. ${ }^{26}$

In this respect, without educational programmes, research, industrialisation development and a broader innovation system, the local industry will not be able to develop and take advantage of the exceptionally large sized Indian pharmaceutical market to reduce drug pricing through high innovation quantities. ${ }^{27}$ Under this reality, not only will the Indian population be denied low cost patented drugs but the other poor populations of the world, which rely on India's drug production, will be excluded from low cost patented drugs as well. ${ }^{28}$

However, it is important to emphasise that the thesis does not aim to offer an overnight solution to the high cost patented drug market, or to exempt the Indian Government from establishing stronger healthcare infrastructure and drug price control orders as part of creating an affordable drug marketplace. Until the utilisation of the patent mechanism to the fullest as suggested, the Indian pharmaceutical industry is mostly recommended to use the different flexibilities to the exclusive patentee rights in the marketplace as offered in the TRIPS Agreement as compulsory licensing. ${ }^{29}$ Notwithstanding, this recommendation is not to be used as a bargaining tool to overpower the patentee's rights, but to use in true times of need to maintain a healthy and productive society during the awakening of a stronger Indian innovative pharmaceutical industry .

On the other side still lies the responsibility of the Western advanced pharmaceutical industry to the developing world's population, not only through foreign direct investment and technology transfer, but in delivering drugs at lower prices in their benefit-cost frame. As long as India offers vast protection of patent, and promises that generics will not threaten the prospect of the industry to recoup its investment, the Western richer industry, as a beneficial party from the Indian industry

\footnotetext{
${ }^{26}$ Ibid.

${ }^{27}$ See Todaro, Smith, above n 11, 15.

${ }^{28}$ See Grace, above n 17, 13.

${ }^{29}$ See TRIPS Agreement, above n 1, art 31. According to the TRIPS Agreement member countries were allowed to implement in their legislation the mechanism of compulsory licensing as brought by Article 31 of the Agreement. According to the Article, generic firms can, under certain terms, to copy a patented drug regardless to the patentee's approval.
} 
ought to ensure that the human right for good health will not be forced aside by the human right of property. Only a quid pro quo relationship will elevate patent as drug accessibility enabler.

In other words, examining the enforcement of larger patent protection enforcement in the Indian pharmaceutical industry will not only show how patent has the power to advance and strengthen a pharmaceutical industry in a developing country, it will also break the myth behind patent as a right whose enforcement is suitable only in rich countries, one which, if enforced by developing countries, would only increase the barriers to drug accessibility. The following chapters of the thesis sketch patent protection as a concrete and realistic plan to add to the wide range generic drug pool in India by introducing protection of pharmaceutical incremental innovation, as a positive prospect to reduce prices of patented drugs. Between India's special economic progression, its large market size and existing pharmaceutical innovative skills, the growing purchasing power, enforcing a wider scope of patent protection within the pharmaceutical industry may be a frightening decision at first; however it will be proven otherwise.

The thesis is divided into eight chapters. Following the introduction chapter the second chapter presents the parties impacted by the prospect of pharmaceutical patenting, as well as the rights impacted by it, such as the right of property and health. Although the resulted increase in drug pricing due to patent enforcement, the chapter suggests that patenting pharmaceuticals in developing countries can offer low cost route to drug use, more than developing countries are willing to admit. This presumption is shown by reviewing patent's encouragement of innovation and investment, relying on India's emerging economy and innovative pharmaceutical industry. The third chapter reviews the pharmaceutical industry on its two main levels of innovation, with special emphasis on incremental innovations. The formation of India's generic pharmaceutical industry, its colossal importance to the poorer population healthcare and the parallel introduction of patent protection by India's signing the TRIPS Agreement, is reviewed in the forth chapter. After signing the TRIPS Agreement, the fifth chapter shows the vast investment patent has invited to the Indian pharmaceutical industry from Western industries, which establishes the 
connection of patent to form a forte independent innovative pharmaceutical industry and generate a direct impact on the reduction of drug pricing.

As a complementary analysis, the sixth chapter notes of the importance of patenting incremental pharmaceutical innovation in India. This suggested step is the final step needed to enlarge the local industry to form an enlarged patented drug market competition and reduce drug pricing. In this respect the chapter concludes the necessity to amend the Indian Patents Act to introduce the patenting of pharmaceutical incremental innovation. Although under the TRIPS Agreement the primary obligation is to enforce patent protection on pharmaceuticals, the pharmaceutical industry in the developed world is primarily morally obligated to offer a low cost drug supply to the poorer population in developing countries while the latter try to form a large scaled pharmaceutical marketplace as advocated in the seventh chapter. The eighth chapter concludes of the influential role patent has to form an accessible route to drugs in developing countries and break the myth behind patent as a barrier to low cost drugs. 


\section{PATENTING PHARMACEUTICALS - FURTHER OBSERVATIONS}

\section{A. Does Patenting Pharmaceuticals Enable or Deter Drug Accessibility in}

\section{Developing Countries}

\section{Characteristics of the developing world}

In the tenth edition of Todaro and Smith's research "Economic Development", one of the preliminary observations was the extreme contrast exists in the global economy of today. ${ }^{30}$ They mainly referred to the differences that exist between the developed and the developing world. ${ }^{31}$ The research covered the scholars' references to different dimensions such as market productivity, human capital supply, poverty rates, population growth, areas of living (rural/urban), levels of industrialisation and more. ${ }^{32}$ For the basic comparison, the authors found that India's output per worker is 10 times lower than the one in the United States. ${ }^{33}$ If the annual income per capita in the United States is US\$41,950, the average income in India is US\$3460 and US\$720 in the Democratic Republic of Congo. ${ }^{34}$

The average life expectancy is 74 in the United States, 64 in India and only 44 in the Democratic Republic of Congo. ${ }^{35}$ The authors also compared the literacy rates between developed and developing countries and found that in comparison to the United States where all women are literate, in India only 48 per cent of the women are literate and 54 per cent in Democratic Republic of Congo. ${ }^{36}$ Needless to say, factors such as education and literacy heavily impact on the quality of the available human capital in the marketplace and the direction it would lead a country's economy and health.

Usually, a country's development level is based on its per capita income. ${ }^{37}$ The International Bank for Reconstruction and Development (known as the World Bank) ${ }^{38}$

\footnotetext{
${ }^{30}$ Todaro, Smith, above n 11,41-42.

${ }^{31}$ Ibid, 39.

32 Ibid, 40 .

${ }^{33}$ Ibid.

34 Ibid.

${ }^{35}$ Ibid.

${ }^{36}$ Ibid.

${ }^{37}$ Ibid, 41

${ }^{38}$ The World Bank www.worldbank.org (accessed 1 September 2009).
} 
classifies development as follows: ${ }^{39}$ low-income countries characterised with up to US\$875 per capita gross national income, lower-middle income countries characterised with US\$876 - US\$3465 income, upper-middle income countries characterised with US\$3466 - US\$10,725 income and high-income countries characterised with no less than US\$10,726 income rates. Developing countries are characterised as low to upper -middle income countries. ${ }^{40}$ India, for example, located in the South-Asia region is classified as a low-middle income country. ${ }^{41}$

As can be expected, low income levels lead to poor education, poor health conditions and weak infrastructure, which lead to low productivity rates, economic instability, poverty and again to low income levels. ${ }^{42}$ This vicious cycle is difficult to escape from. Developing countries on the lower scale, where India is located, are also commonly characterised with low levels of human capital which can be expected to be imperative to a country's economic growth. ${ }^{43}$ With respect to the developed world, developing countries lag behind in health, education, nutrition and suffer from 15 times higher death rates. ${ }^{44}$ Although the scholars acknowledged the progress that was achieved in countries in South-Asia such as India, ${ }^{45}$ they still stressed the high rates of illiteracy, poor schooling attainment and nourishment, ${ }^{46}$ which are vital parameters to becoming a part of the new modern international economy and being able to be active in an expensive and complex industry like the pharmaceutical industry.

High poverty rates are another parameter which distinguishes the developing world from the developed, ${ }^{47}$ which needless to say hinder the engagement of the local industry with high quantity of pharmaceutical innovation, the same as high population growth $^{48}$ and high death rates. ${ }^{49} \mathrm{~A}$ high percentage of people living in rural areas, who mostly practice agriculture, is another economic parameter in developing countries

\footnotetext{
${ }^{39}$ Country Classification http://go.worldbank.org/K2CKM78CC0 (accessed 1 September 2009). See also Todaro, Smith, above n 11, 41.

${ }^{40}$ See Todaro, Smith, above n 11, 41.

${ }^{41}$ Ibid, 42. See also Country Classification, above n 39.

${ }^{42}$ See generally Todaro, Smith, above n 11, 56.

43 Ibid, 58.

${ }^{44}$ Ibid, 59.

${ }^{45}$ Ibid. See also Part II D 1 The socio-economic outlook.

${ }^{46}$ Todaro, Smith, above n 11, 59.

${ }^{47}$ Ibid, 59, 208.

${ }^{48}$ Ibid, 61-62.

${ }^{49}$ Ibid, 63.
} 
leading to the neglecting of manufacturing or services routes, ${ }^{50}$ which are highly lucrative avenues in a country's economy. ${ }^{51}$ Nevertheless, achieving the goal of industrialisation cannot be fulfilled in an unhealthy society with sick human capital and when referring to developing countries, one cannot dismiss the burden these countries carry with so many diseases in comparison to economically developed countries. $^{52}$

With poverty leading as a prime disease, ${ }^{53}$ tuberculosis claims two million lives every year in the developing world, ${ }^{54}$ hepatitis B claims one million lives each year, ${ }^{55}$ as well as cholera, leprosy, lymphatic filariasis, ${ }^{56}$ which constantly increase the number of deaths. Science is not the problem, for science can lead to a cure of these diseases. However, the low available capital of the developing world Governments is. ${ }^{57}$ Without the possibility of a financial return in its investment from the developing world markets, the pharmaceutical industry in Western countries will not engage in research and development of drugs to treat tropical diseases, fearing it will have to push the prices of the invented drugs down. ${ }^{58}$ For this reason, tropical diseases are often referred to as neglected diseases or "orphan" diseases, for the minor research they attract. ${ }^{59}$

Even countries such as India, Brazil, South Africa, with a sizeable middle class like in industrialised developing countries, ${ }^{60}$ and ones which the thesis addresses its recommendation to, suffer from the above characteristics and struggle with high rates of poverty, lack of proper education, lack of basic infrastructure stability and the above diseases at epidemic rates. ${ }^{61}$ Thus, their preference for the production of

\footnotetext{
${ }^{50}$ Ibid, 64.

51 Ibid.

${ }^{52}$ Ibid, 400. See also WHO Report 2007 Global Tuberculosis Control: Surveillance, Planning,

Financing (WHO, Geneva, 2008).See also WHO World Malaria Report 2008 (WHO, Geneva, 2008).

${ }^{53}$ Todaro, Smith, above n $11,400$.

${ }^{54}$ Ibid.

${ }^{55}$ Ibid, 401.

56 Ibid.

${ }^{57}$ Ibid, 407.

${ }^{58}$ Ibid, 408.

${ }^{59}$ Patrice Trouiller and others "Drug Development for Neglected Diseases: A Deficient Market and a Public-Health Policy Failure" (2002) 359 (9324) The Lancet 2188, 2188.

${ }^{60}$ Bebe Loff, Mark Heywood "Patents on Drugs: Manufacturing Scarcity of Advancing Health?" (2002) 30 Journal of Law, Medicine \& Ethics 621, 624-625.

${ }^{61}$ Ibid .
} 
generic drugs is no different than low-income developed countries like Afghanistan or the Yemen. ${ }^{62}$

The constant tension between the developed countries, known as the "North", and the developing countries, known as the "South" concerning patent enforcement of pharmaceuticals is not solely involved with the right of each one to healthcare. The right of the pharmaceutical firm to enjoy a proper return for its investment and prevent the generic copying of the costly invention is an equally important factor which should not be overlooked. In order to fully understand whether patent enforcement of pharmaceuticals can be used as an alternative route to achieve low cost drugs market further analysis of the two parties, the developing and the developed worlds' concerns, risks and needs, is essential. In this respect and after reviewing the landscape of the developing world, the next section investigates the true meaning of patenting pharmaceuticals.

\section{North to south outlook}

Reviewing the developing world outline of diseases and high death rates, it can be declared that the pharmaceutical research and development activity is not complete. The prospect of the evolvement of new diseases and the need to develop cures for major existing ones like cancer, AIDS, other infectious diseases and heart diseases, strengthens the importance of continuing research activity by the pharmaceutical industry. It is also obvious that diseases have no borders and the recent case of swine flu highly exemplifies this assessment. The latter statement is to say that the need for continuous research activity of the pharmaceutical industry is a mutual need of both the developed as well as the developing countries.

Regardless of the mutual need for drugs, only the developed world is capable of advanced pharmaceutical research and development to find cures for the aforementioned diseases, for only the developed world has the required education, skills and the capital to invest in the costly process of pharmaceutical innovation. In addition to the cost, the length and the complexity of the process and the extensive competition within the industry also offer further justifications for patent protection

\footnotetext{
${ }^{62}$ Country Classification, above n 39.
} 
enforcement in the international marketplace with no exceptions, as a way to reduce the industry's risk of not being able to recoup the costly investment. Nevertheless, one can ask what the benefits of introducing a new drug to the market are without the capacity to sell it or use it.

Although the developing world has agreed to be a part of an international intellectual property rights regime, the cost-benefits of the drug innovation conundrum is not solved. On the one hand, suffering from economic instability and lacking sufficient technologies and innovative "knowhow" skills in the pharmaceutical industry, developing countries are pushed to rely on the technologically advanced and economically robust counterparts in the West to develop new drugs. On the other hand, offering property protection on invented drugs through patent, which denies the immediate generic copying of a drug, can result in a life of sickness in developing countries, a sickness which could be cured only if the drugs were affordable. ${ }^{63}$

Opponents of international intellectual property protection enforcement have often argued for a differential setting of intellectual property rights regime in developing countries to maximise accessibility to Western technologies. ${ }^{64}$ Lacking an adequate purchasing power equivalent to the developed world population, patent enforcement was not to promise accessibility to Western pharmaceutical skills and technologies, or a chance to facilitate and advance the local existing pharmaceutical industries innovative capacity. ${ }^{65}$ Without the needed purchasing power, intellectual property rights were not to foster technology transfer. Generics copying rights however, were. Blinded by the fear of high priced drugs, India, the country which has better chances to benefit from vast enforcement of intellectual property compared to other smaller developing industrialised countries, was the leading opponent to signing the TRIPS Agreement. $^{66}$

\footnotetext{
${ }^{63}$ See Tina S Bhatt "Amending TRIPS: A New Hope for Increased Access to Essential Medicines" (2007-2008) 33 Brook J Int'l L 597, 599, 602-603.

${ }^{64}$ See generally Danielle L Tully "Prospects for Progress: The TRIPS Agreement and Developing Countries after the Doha Declaration" (2003) 26(1) BC Int'l \& Comp L Rev 129, 136 - 137.

${ }^{65} \mathrm{Ibid}$.

${ }^{66}$ Jean M Dettmann "GATT: An Opportunity for an Intellectual Property Rights Solution" (1991) 4 The Transnat'l Law 347, 370.
} 
The recent study conducted by All-India Drug Action Network, a Campaign Group for Rational Drug Therapy and Policy published in December 2008, revealed the reality of drug pricing in India. ${ }^{67}$ When a daily average salary in the labour field in India is 60 Rs which equals US\$1.29, ${ }^{68}$ how can one recover from tuberculosis, eat, drink and enjoy proper housing, if the drug is equivalent to 737 days of workdays. Another example is a drug which treats coronary heart disease whose price is equal to 209 days of labour work in India. ${ }^{69}$ There are many more examples published in the report which together with the poor healthcare infrastructure in India can demonstrate the difficulty in offering patent protection of pharmaceuticals to the immediate accessibility to drugs. ${ }^{70}$

In retrospect, a fair question would be how one chooses one result over the other. How one chooses to omit patent protection enforcement in order to access drugs, when the same step can hinder the drug's innovation. According to Indira Gandhi, there it is not a matter of choice. Gandhi's view as stated in the World Health Assembly in 1982 pointed to one result only, one which would end with full access to drugs by anyone in need of them and as stated:"the idea of a better -ordered world is one which medical discoveries will be free of patents and there will be no profiteering from life and death". ${ }^{71}$ However, Gandhi did not give any weight to the fact that without patent protection, the pharmaceutical industry will not engage in further drug discoveries.

Therefore, a proper balance does not seem to be one which omits patent protection enforcement from the pharmaceutical technology field, rather one which is sourced within the patent mechanism. Although this presumption is not common, it can be implied in developing countries. Notwithstanding the importance of accessing drugs by all human beings, rich or poor, and the difficulties patent can put in the direct way to achieve this goal, a deeper observation of the tension existing between the developed and the developing countries' interests reveals additional layers. The avenue of the pharmaceutical firm's right to enjoy a proper return for its investment

\footnotetext{
${ }^{67}$ Drug Prices and Affordability, above n 23.

${ }^{68}$ Ibid. See also www.x-rates.com (accessed 18 October 2009).

${ }^{69}$ Drug Prices and Affordability, above n 23.

${ }^{70}$ Ibid.

${ }^{71}$ See Michael R Gadbaw, Timothy J Richards (eds) Intellectual Property Rights: Global Concerns, Global Conflicts? (Westview Press, United States of America, 1988) 186.
} 
obliges an analysis of patent as a defender of the private individual human right of property, or if you will, the pharmaceutical firm right to enjoy exclusivity over its invention.

The next section of the chapter which opens with the philosophical justification of patent protection, further lays the importance of the two human rights of property and health and, as they represent the right of the private and the right of the public respectively, a warning of market failure is given if one right is enforced without the other. In other words, the next part of the chapter draws additional avenues which exist within patent alone, as well as facing the right for health and interestingly shows how one is fulfilled by the other; how patent enforcement of pharmaceutical innovation enables a better utilisation of the right of health through drug innovation.

\section{B. The Private - Public, Property- Health paradox in Patenting Pharmaceuticals}

The protection patent offered to the pharmaceutical innovator shows the power patent has in protecting private rights and at the same time public rights by offering needed new products to the marketplace. However, as much as the aspect of patent privatisation compliments the needs of the public, if applied in developing countries markets, patent can discriminate the rights of the public. Notwithstanding the aforementioned risk, it is essential to emphasise that the right of the public could never be utilised without the right of the private for there could not have been any new product to enjoy. In other words without a patent protection for pharmaceutical innovation, there would not be any drugs to treat any disease. Would that be a better result for the world's poor and sick? It seems that the answer to this question is no.

The philosophy behind patent protection is the one behind property protection and can be based on both philosophies constructed by two of the leading scholars in the field of liberalism and the relationship between the state and the individual, John Locke and Georg Hegel. John Locke, the father of liberalism and modern democracy, had an immense affect on the establishment of the conception of private property. Locke defined property as a result of labour. ${ }^{72}$ According to Locke, when God gave the world to the common, he commanded mankind to subdue the earth for one's

\footnotetext{
${ }^{72}$ See John Locke Two Treaties of Government (vol V, London, 1823) 118.
} 
benefits. $^{73}$ Thus, to acquire property rights to something (which is not owned by others) one has to invest labour in it. ${ }^{74}$

The correlation to intellectual property rights, inclusive patent protection, is explicit; people are entitled to their mental "work" and their creations. ${ }^{75}$ Although the philosopher Hegel adopted a conservative approach to liberalism, he still respected the creator's autonomy and stated that the creator should have a control over the creation once showing close association to it. ${ }^{76}$ So a pharmaceutical firm, on the basis of these two philosophical approaches, which has invested capital and work in drugs innovation, ought to enjoy its creation as its owner.

In trying to analyse the conflict that exists between public goods and intellectual property rights which primarily protect the right of the private, Drexel's recent study sketched patent as a vehicle to transform products from the use of the common to a closed club goods. ${ }^{77}$ By club goods Drexel meant that patented drugs consumption is possible only following the remuneration of the patentee. ${ }^{78}$ Hence, people who are unwilling or unable to compensate the rights' holder will be excluded from enjoying the product. ${ }^{79}$ In other words, under the patent mechanism, drugs are transformed to club goods and thus are not available to people living in developing countries for they are not capable of purchasing them.

In the same avenue to prioritise the importance of the rights of the private to encourage technological advancement in the market, Hardin, the originator of the 'tragedy of the commons theory, defended the importance of property protection while criticising wide non compensating common use of private resources. ${ }^{80}$ According to Hardin's theory, without privatisation of goods, the market will suffer from

\footnotetext{
${ }^{73}$ Ibid.

${ }^{74}$ Ibid, 116. See also Michael Spence Intellectual Property (Oxfor Universtiy Press, New York, 2007) 52.

${ }^{75}$ See Justin Hughes "The Philosophy of Intellectual Property” (1988) 77 Geo LR 287, 301.

${ }^{76}$ See GWF Hegel Outline of the Philosophy of Right (Oxford University Press, New York, 2008) 235.

${ }^{77}$ See Josef Drexel "The Critical Role of Competition Law in Preserving Public Goods in Conflict With Intellectual Property Rights" in Keith E Maskus, Jerome H Reichman (eds) International Public Goods and Transfer of Technology Under Globalized Intellectual Property Regime (Cambridge University Press, New York, 2005) 711, 712.

${ }^{78}$ Ibid.

79 Ibid.

${ }^{80}$ See Garrett Hardin "The Tragedy of the Commons" (1968) Science 162 (3859)1243.
} 
exhaustion through over-exploitation of resources and their value will be reduced to zero. $^{81}$

As often claimed by the pharmaceutical industry, without protecting drug innovation through patent, without being able to enjoy market exclusivity to hinder generic competition, there will be no motivation for the industry to activate in drugs development and, as a result, the world's ordinary people will be primarily affected by higher deaths and sickness rates. The immense impact of generics on the pharmaceutical industry productivity should not be dismissed or treated as a minor factor. Statistics show that a patented original drug can be generically produced in 10 versions, ${ }^{82}$ priced at no more than 10 per cent of its original cost. ${ }^{83}$ Needless to say, the low price of generics has a substantial power to reduce the patented drugs' pricing and affect the pharmaceutical industry's ability to recoup its investment.

In this respect the necessary conclusion would be that without the privatisation of the pharmaceutical industry's products, the generic competition will exhaust and diminish any incentive the pharmaceutical industry has to engage in the sacred work of drugs' innovation to better humanity health care. This result, under today's continued diseases, plagues and new disease formation can be devastating for the entire sick population from the developed as well as from the developing world. So that without respecting the right of the private, the public would not benefit from the introduction of new drugs into the marketplace and as claimed before, this result is far from offering the optimal solution for the world.

However, and in respect to the importance of the private right to enjoy private control over the invention, a fair question would concerns the benefits the private party would gain in a non-consuming market. Despite the importance of properties drugs' innovation through patent as a motivator of innovation, it can also cause an opposite result of the 'tragedy of the anti-commons' as Heller deterred. ${ }^{84}$ Heller and

\footnotetext{
${ }^{81}$ Ibid.

${ }^{82}$ See Sierra Dean "India's Controversial New Patent Regime: The End of Affordable Generics?" (2006) 40 Int'l Law 725, 726. 
Eisenberg have also designated the result of the tragedy of the anti-commons in respect to the pharmaceutical industry, and argued that in the biomedical research field patent can foil affordable products in the marketplace. ${ }^{85}$ The authors respectively criticised Hardin's view that did not take under consideration that privatisation can cause underused market's resources, ${ }^{86}$ which would not benefit the market's economy as well.

Drexel's view can complete this aspect of the tension that exists between the right of the private opposed to the right of the public. He justified privatisation by property rights as long as the benefits they hold outweigh the costs of excluding a wide ranged common use of the patented product. ${ }^{87}$ Patent protection by its nature does not answer this outcome in the extensive poor populated developing world markets where in regards to pharmaceuticals, the majority population cannot afford the patented drugs. Unable to afford drugs, the poorer population of the world is doomed to suffer and die from treatable diseases. Obviously under this interpretation, the death of so many people outweighs the cost the private pharmaceutical industry may have to bear by offering low cost drugs or free from cost drugs to the developing world population.

The value of presenting the two aspects that exist in patent enforcement is of immense importance to the discussion of patenting pharmaceuticals. As the private force encourages the introduction of new advanced needed drugs to the marketplace and the public demands the utilisation of the private pharmaceutical innovative activity, omitting one is not possible for these two parties rely on each other. This is to say that determining which one ought to be prioritised, the right of the private or the right of the public is not the right task. Rather, finding the right balance to this delicate conflict is. Although privatisation can solve one tragedy, it can cause another. ${ }^{88}$ Thus as much as it is a contradictory relationship, the private-public pair has a supplementary relationship, one which ought to be enforced as soon as possible in the notion of patenting pharmaceuticals in the developing world.

\footnotetext{
${ }^{85}$ See Michael M Heller, Rebecca Eisenberg "Can Patents Deter Innovation? The Anticommons in Biomedical Research" (1998) 280 Science 698, 698.

${ }^{86}$ Ibid.

${ }^{87}$ See Drexel, above n 77, 713.

${ }^{88}$ See generally Heller, Eisenberg, above n 85 .
} 
As a supplementary discussion to the tension existing between the right of private and the right of the public in the area of patenting pharmaceuticals, the human right of property stand in comparison to the human right of health analysis is in order. ${ }^{89}$ However, just as the right of the private and the public ought to be accepted as complementary rights, so ought the rights of property and health. Given that these two rights were put on the same platform of importance as human rights in the Universal Declaration of Human Rights, ${ }^{90}$ emphasises the fact that they should not compete with each other but complement each other. This premise is of special importance concerning the patenting of pharmaceuticals, for patent protection can encourage innovation of drugs, which are of benefit to humanity's right for health.

The international community acknowledges the two rights of property and health. As the Universal Declaration of Human Rights, the United Nations International Covenant on Economic, Social and Cultural Rights Covenant 1966, ${ }^{11}$ acknowledges the two human rights of property and health and tries to balance them. ${ }^{92}$ Nevertheless, in General Comment 14, it was declared that the right for health is a superior right. ${ }^{93}$ In practice, the Covenant's provisions state that parties ought to recognise: "the right of everyone to the enjoyment of the highest attainable standard of physical and mental health". ${ }^{94}$ In the European practice, the Charter of Fundamental Rights of the European Union, ${ }^{95}$ acknowledges the private-public rights tension, with special emphasise to protect intellectual property rights. ${ }^{96}$

\footnotetext{
${ }^{89}$ See The Universal Declaration of Human Rights UNGA Resolution 217(III) (10 December 1948), art $17,25$.

${ }^{90}$ Ibid.

${ }^{91}$ UNHCHR Resolotion 2200A (XXI) (16 December 1966), art 15(1).

${ }^{92} \mathrm{See}$ generally Duncan Matthews "Intellectual Property Rights, Human Rights and the Right to Health"(Legal Studies Research Paper No 24/2009, Queen Mary University of London, 2009) 1, 45. ${ }^{93}$ UN Economic and Social Committee General "The Right to the Highest Attainable Standard of Health (Article 12 of the International Covenant on Economic, Social and Cultural Rights)" (11 August 2000) E/C.12/2000/4, para 1.

${ }^{94}$ Ibid, para 12 .

${ }^{95}$ Council Commission 2007/C Charter of Fundamental Rights of the European Union [2007] OJ En Ed 303/1.

${ }^{96}$ Ibid, art 17:

1. "Everyone has the right to own, use, dispose of and bequeath his or her lawfully acquired possessions. No one may be deprived of his or her possessions, except in the public interest and in the cases and under the conditions provided for by law, subject to fair compensation being paid in good time for their loss. The use of property may be regulated by law in so far as is necessary for the general interest.

2. Intellectual property shall be protected"
} 
Although it may appear that there is tension between property and health in the spectrum of patent enforcement and the need to access drugs, according to Dreyfuss, there should not be one. Dreyfuss does not see intellectual property rights as equally leveled with the human right of property. Hence Dreyfuss did not see patent as a threat to the superior human right of health. ${ }^{97}$

Dreyfuss supported her conclusion on several levels. She viewed patent as a right which lies on utilitarian justification ${ }^{98}$ in comparison to the perception that patent is firstly a right which grants an exclusive market control to the patentee. Hence, there should not be a matter of tension between the right of the public and the right of the patentee, not on the spectrum of human rights. ${ }^{99}$ From a utilitarian perspective, patent's promotion of scientific developments belongs to the public. At the end of 20 years term, the patentee loses the exclusive control over the product to the public ${ }^{100}$ and the generic firm is allowed to copy the drug without any legal restrictions. This is to say that according to Dreyfuss patent is a right for the public more than it is a right for the preivste.

Another aspect Dreyfuss referred to was the temporary and unstable aspect of patent exclusive right. ${ }^{101}$ The option to enforce the patentee compulsory licensing, ${ }^{102}$ the external limitations on patent as in cases of antitrust scrutiny ${ }^{103}$ might be taken as meaning that the patent right does not fall in the scope of property right as the Declaration of Human Rights intended. Thus, one can conclude that the superiority of the right of health is a prior consideration. ${ }^{104}$

Nevertheless, although Dreyfuss raises a legitimate aspect of patent nature, her analysis did not relate to a repetitive motive in the institute of patenting pharmaceuticals and that is the pharmaceutical industry's reliance on patent's

\footnotetext{
${ }^{97}$ See Rochelle C Dreyfuss "Patents and Human Rights: Where is the Paradox?" (Law and Economics Research Paper, New York University School of Law, 2007).

${ }^{98}$ Ibid.

${ }^{99}$ Ibid.

${ }^{100}$ Ibid.

${ }^{101}$ Ibid

${ }^{102}$ Ibid

${ }^{103}$ Ibid.

${ }^{104}$ See generally eBay, Inc v MercExchange (2006) 126 S Ct 1837, 1840 - 1841. See also the precedent case Roche Products, Inc v Bolar Pharmaceutical Co (1984) 733 F 2d 858 (Fed Cir).
} 
exclusivity nature as a motivator to innovate. ${ }^{105}$ Discussing the private-public, property-health tension exists within patenting pharmaceuticals, does not seem to be relevant for there should not be a resolution of which right is superior to the other.

There should be a balance between the two prime considerations of property and health. This balance can be formed through the strengthening of the developing world's pharmaceutical industry. A stronger and advanced pharmaceutical industry would promise local innovation, participation in the global arena and the needed competition to influence the consumer market prices. Although patent enforcement can prioritise the rights of the patentee in the marketplace, it has further avenues, some of which would promise to build a stronger and larger pharmaceutical industry in the developing world, which is of prime importance in enabling easier accessibility to patented drugs.

The next section presents two practical elements within patent enforcement which ought to benefit the developing world's accessibility to patented drugs by establishing an advanced innovative pharmaceutical industry. The following and the final part of the chapter designated to India as it was chosen as a case study, emphasises its socio economic features followed by its relatively advanced pharmaceutical industry compared to other developing countries. As advocated earlier, these given characteristics make India potentially one of the most able countries to fulfil the advocated recommendation.

\section{Patent as a Mediation Force}

The question whether patenting pharmaceuticals enables or deters drug accessibility is not a simple question, especially asked in the background of the developing countries which start from less fortunate economic platforms. However, at the same time, it seems that the tendency is to support patent as a drug accessibility enabler. The prime ground which justifies this tendency is the simple fact that patent encourages innovation and investment by foreign multinationals, two vital factors which can advance a developing country's pharmaceutical industry to a competitive

\footnotetext{
${ }^{105}$ See Todaro, Smith, above n 11, 89.
} 
level. In respect to the large size of the developing world market, the reality of extensive competition and reduction of drug pricing is founded.

Despite the challenges of globalisation, the pharmaceutical industry has grown to be one of the internationalising sectors in the world. The opportunity this technology promises to the economy of a country through open markets, has invited developing countries to become a part of this change. However, without intellectual property protection, developing countries could not have completed the transformation to become a part of this change. ${ }^{106}$

A key factor in developing countries gaining drug accessibility is their reliance on the developed world's innovation. Although the industrialised developing countries have achieved various innovative skills, they are still lagging behind the Western technological capacity and are not yet capable of engaging in the complexity the pharmaceutical research can often demand. The pharmaceutical industry in India has achieved substantial progress and even adapted innovative skills to some extent, however, not to the extent it can conduct large and independent pharmaceutical research and development. ${ }^{107}$ With the needed innovative skills, India would be able to improve its chances of better health care through low cost drugs supply.

A large market size is potentially one which is able to offer lower consumer costs, for it would invite larger amount of drugs and raise the numbers of pharmaceutical competitors. One example of a country with large market size is China, with 1.3 billion people. ${ }^{108}$ India with close to 1.2 billion $^{109}$ and Brazil nearing one billion ${ }^{110}$ are examples of developing countries which would be able to enjoy from extensive price reducing competition in the pharmaceuticals marketplace, as long as their pharmaceutical industries are capable of large - scaled innovation practice. In comparison, there are just above 300 million people in the United States ${ }^{111}$ and 70

\footnotetext{
${ }^{106}$ See Douglas Lippoldt “Intellectual Property Rights, Pharmaceuticals and Foreign Direct Investment" (2006) 2, 3 www.gem.sciences (accessed 11 November 2008).

${ }^{107}$ See generally Joanna Chataway, Joyce Tait and David Wield "Frameworks for Pharmaceutical Innovation in Developing Countries - The Case of Indian Pharma" (2007) 19(5) Technology Analysis \& Strategic Management 697, 702. See also Part II D 2 The Indian pharmaceutical Industry.

${ }^{108}$ See Country Data: China provinces http://global-dem.com (accessed 19 October 2009).

${ }^{109}$ See Country Data: India states http://global-dem.com (accessed 19 October 2009).

${ }_{110}$ See Country Data: Central and South America http://global-dem.com (accessed 19 October 2009).

${ }^{111}$ See Country Data: North America http://global-dem.com (accessed 19 October 2009).
} 
million in the United Kingdom, ${ }^{112}$ which would not be able to enjoy from similar influential price reducing market forces through competition. Nevertheless, and as stated earlier, the only parameter which delays the developing world from establishing large pharmaceutical industries, is the technological skill of innovation.

Lacking proper innovative skills is especially worrying in the developing world due to the specific need for drugs to treat tropical diseases such as malaria, tuberculosis and leprosy. The designation of research on tropical diseases by the Western pharmaceutical industry is considerably small for the small potential return the industry can obtain from selling the drugs in the developing world markets. ${ }^{113}$ Needless to say that without proper innovative skills and the continued reliance on Western firms, the developing world cure from these treatable diseases is not to be obtained. Kyle and McGahan noted that even following the introduction of an international intellectual property right regime, the developed world's pharmaceutical industry did not engage in more research and development activity in pharmaceutical for tropical diseases as much as on global diseases as cancer or heart diseases. ${ }^{114}$ This is to say that the responsibility to allocate enough tools, technological and managerial skills, lies on the shoulders of the developing world's pharmaceutical industry. This responsibility can be answered with patent as a contractor of research and development skills.

Many studies have examined and proven the strong connection between wide patent protection enforcement to local innovative activity and the push of technology transfer into the developing world, ${ }^{115}$ especially in the high-tech industry as the pharmaceuticals. ${ }^{116}$ As shown earlier, patent has not been perceived as stimulating innovation in the enforcing market not only due to the opportunity it gives for the patentee of higher prices levels, but for its assurance that any third party would not be able to copy the product and compete with it. ${ }^{117}$ Hence, as long as the local innovation

\footnotetext{
${ }^{112}$ See Country Data: Western Europe http://global-dem.com (accessed 19 October 2009).

${ }^{113}$ See generally Trouiller and others, above n 59, 2188. See also Grace, above n 17, 39. See also

Bernard Pe`coul "Access to Essential Drugs in Poor Countries: a Lost Battle? (1999) 281(4) Jama 361.

${ }^{114}$ See Kyle, Mcgahan, above n 13, 18.

115 See Part V B Patent as a Leading Motivator of Foreign Direct Invesmtnet.

${ }^{116}$ See Assad Omer "Access to Medicines: Transfer of Technology and Capacity Building (2001-2002)

20 Wis Int'1 LJ 551, 555.

117 See Robert M Sherwood "The TRIPS Agreement: Implications for Developing Countries" (19961997) 37 Idea 491,500.
} 
is protected through patent, the local industry would not fear from introducing its costly inventions to the local market and it will be further encouraged to conduct research for local needs and not only for the lucrative Western markets.

As part of examining how the stronger patent enforcement impact on the local industry's level of innovation in a developing country, it is noteworthy to review the potential power patent has in introducing to the industry the much needed technical tools of innovation it lacks. One prime avenue to achieve this end lies in international technology transfer. ${ }^{118}$ Through technology transfer, the recipient country can enjoy better public health through improved public availability of new technologies, utilising intellectual property rights, attracting new research, increasing public investment returns, and motivating economic and technological development. ${ }^{119}$

Foreign direct investment is one of the routes of technology transfer. ${ }^{120}$ The format of foreign direct investment can be divided into several levels of local foreign collaboration from establishing new branches or subsidiaries, to acquiring controlling shares in existing firms in the host country or participating in joint ventures. ${ }^{121}$ Through this process, pharmaceutical multinationals not only can direct their investment in finance, but transfer technology, business expertise and assist the hosting industry to access the global market. ${ }^{122}$ Investing firms can also transfer management skills, technological skills, training programs, contact with overseas banks and locating sources of supply to assist the local industry to become a better practitioner in international marketing practices. ${ }^{123}$ The wider result will be the reform

\footnotetext{
${ }^{118}$ See Cheri Grace Leveraging the Private Sector for Public Health Objectives: A Briefing Paper for DFID on Technology Transfer in the Pharmaceuticals Sector (prepared for the British Government's Department for International Development, 2004).

${ }_{119}$ Ibid.

${ }^{120}$ Keith E Maskus, Jerome H Reichman "The Globalization of Private Knowledge Goods and the Privatization of Global Public Goods" in Keith E Maskus, Jerome H Reichman (eds) International Public Goods and Transfer of Technology Under Globalized Intellectual Property Regime (Cambridge University Press, New York, 2005), 11. See also Sherwood, above n 117,503-504.

${ }^{121}$ Mark B Baker "Awakening the Sleeping Giant: India and Foreign Direct Investment in the $21^{\text {st }}$ Century" (2005) 15 Ind Int'l \& Comp L Rev 389,405. See also Jean O Lanjouw "The Introduction of Pharmaceutical Product Patents in India: Heartless Exploition of the Poor and Suffering?" (Center Discussion Paper, Yale University Connecticut, 1997) 1, 29.

${ }^{122}$ See generally Baker, above n 121, 405 - 407.

${ }^{123}$ Todaro, Smith, above n 11, 720.
} 
of the developing country's market failure and becoming a part of the global modernised economy. ${ }^{124}$

Striving for growth, the developing world needs to be part of the changing technology, its progress and advancement. It is essential to complete the transformation of the existing economy to a more advanced one. Respectively, improved technology practiced in the marketplace, high domestic productivity and innovation inflows will be introduced to contribute to the economic outline of a country. ${ }^{125}$

The ability to practice the transferred technologies is of a prior importance for the development of the invested industry, which can explain why least developed countries are not able to benefit from patent, at least not in the stage they are today. ${ }^{126}$ Economies with limited technological capacity are also not attractive markets for investment, for they would not answer the expectations of multinationals for low priced and quality services. ${ }^{127}$ Moreover, recipient host countries of foreign investment are more likely to economically benefit from the transferred technologies if they hold a competitiveness platform, large market and industries which in developing countries are of immense importance to mend their market failure. ${ }^{128}$

Benefits from patent enforcement will not appear overnight. One may hold that generics are still a better solution for the developing world conundrum of drugs accessibility. Furthermore, with the vast success of the Indian generic industry in Western countries, it is beneficial for the Indian pharmaceutical industry to continue and practice in generics production. It was recently estimated that the generic

\footnotetext{
${ }^{124}$ See generally Samuel Kortum "Comment II: TRIPS and Technology Transfer - Evodemce from Patent Data" in Keith E Maskus, Jerome H Reichman (eds) International Public Goods and Transfer of Technology Under Globalized Intellectual Property Regime (Cambridge University Press, New York, 2005), 283. See also Arti K Rai "Proprietary Rights and Collective Action: The Case of Biotechnology Research with Low Commercial Value" in Keith E Maskus, Jerome H Reichman (eds) International Public Goods and Transfer of Technology Under Globalized Intellectual Property Regime (Cambridge University Press, New York, 2005),289.

${ }^{125}$ Ibid, 288. See also Keith E Maskus, Kamal Saggi and Thitima Puttitanun "Patent Rights and Intenrational Technology Transfer Through Direct Investment and Licensing" in Keith E Maskus, Jerome H Reichman (eds) International Public Goods and Transfer of Technology Under Globalized Intellectual Property Regime (Cambridge University Press, New York, 2005) 273.

126 See generally Rai, above n 124, 290.

127 Ibid, 291.

${ }^{128}$ Ibid, 289, 291.
} 
pharmaceuticals represents 67.3 per cent of the industry products. ${ }^{129}$ Moreover, most of the largest pharmaceutical firms in India are already collaborating with Western generic firms. $^{130}$

One possible comment to this claim lies in the fact that generics are not necessarily to present low priced drugs as needed, ${ }^{131}$ and furthermore an intense generic activity in the pharmaceutical industry can isolate India from the international innovative pharmaceutical arena. ${ }^{132}$ As Lanjouw stated, it is not the remuneration Indian firms would receive from Western markets for their innovation but it is the fact that soon imitation will not be as lucrative and force a fuller enforcement of patent protection. ${ }^{133}$ In order to keep the profitability in step with international profitability, there is a need to become a part of the international industry and offer protection for pharmaceutical products as it does. ${ }^{134}$

In any case, the economic benefits promised to the Indian treasury from generics will not be jeopardised by wider enforcement of patent protection. ${ }^{135}$ Pharmaceutical multinationals have placed many subsidiaries in India for generic manufacturing and there is not a risk that a wider patent enforcement over pharmaceuticals will deter that opportunity for India. ${ }^{136}$ It would only mean that the fruits of the collaboration would be picked at the end of the patent protection term. ${ }^{137}$ The generic industry in India takes too large a position and importance for it to be hindered completely. ${ }^{138}$ However, a narrow patent scope can deter the growth and the advancement of the Indian pharmaceutical industry, which can risk the promised benefits for the pharmaceutical industry from wider enforcement of patent protection.

\footnotetext{
${ }^{129}$ Tanuja V Garde "India's Intellectual Property Regime: A Counterbalance to Market Liberalization?" (Working paper, Stanford University, 2009) 1, 20.

${ }^{130}$ See Lanjouw, above n 121, 17.

${ }^{131}$ See Maskus, Saggi, Puttitanun, above n 125, 268.

${ }^{132}$ See Rochelle C Dreyfuss"The Role of India, China, Brazil and Other Emerging Economies in Establishing Access Norms for Intellectual Property and Intellectual Property lawmaking" (Institute for International Law and Justice, Working Papers, New York University School of Law, 2009)1,22.

133 See Lanjouw, above n 121, 4, 29.

${ }^{134}$ See Garde, above n 129, 22.

135 See Lanjouw, above n 121, 17-18.

136 Ibid.

${ }^{137}$ Ibid.

138 Ibid.
} 
Following 25 years of generics production, the Indian pharmaceutical industry has accumulated enough resources and skills to engage in some level of innovation. If added to India's market size, its potential growth and advancing economic-social infrastructure and the human capital it has, this low-middle income country can prove patent as a drug accessibility enabler through higher investment inflows and intense innovation and finally break the myth of patent as a drug accessibility barrier in developing countries.

\section{India as a Case Study}

\section{The socio-economic outlook}

According to Beinhocker and Zainulbhai, in 20 years time India's potential economic growth will elevate it above poverty towards becoming the world's fifth largest consumer economy. ${ }^{139}$ Bernstein particularly noted India and China, which are soon to leave developed countries such as United States, Europe and Japan, behind. ${ }^{140}$ As of today, India is considered the fourth largest economy of the world by purchasing power parity, and still lagging behind its potential. ${ }^{141}$ It is placed in the leading second place of gross domestic product among developing nations, based on its growing market and purchasing power. ${ }^{142}$ Additionally, India of today is the second most populous country in the world after China, ${ }^{143}$ which as mentioned, indicates its potential to establish a large competitive pharmaceutical industry. ${ }^{144}$ Clearly these economic elements can explain the attraction of the West to India's markets.

India also enjoys a large educated workforce offered at low cost, particularly in the fields of engineering and science, ${ }^{145}$ which is one of the preliminary factors to attracting foreign direct investment. ${ }^{146}$ Even when compared to China, India's

\footnotetext{
${ }^{139}$ See Eric D Beinhocker, Adil S Zainulbhai “Tracking the Growth of India's Middle Class" (August 2007) The Mckinsey Quarterly 51.

${ }^{140}$ See William J Bernstein "Fast Economies, Elusive Returns" (August 2009) Money 58. See also Joseph Luna "A matter of Time: India's Emerging Economic Prowess" (2006) 27 (4) Harv Int'l Rev 36,36.

${ }^{141}$ See Baker, above n 121, 391.

${ }^{142}$ Ibid.

${ }^{143}$ Ibid.

${ }^{144}$ Ibid.

145 Ibid, 395.

${ }^{146}$ Ibid, 397,398. Baker did forsee that the cost of the Indian services will increase in time, however due to the trend of outsourcing to India and the relatively higher cost for services in developed
} 
prospect of growing workforce, investment and savings is higher. ${ }^{147}$ Statistics show an annual introduction of 200,000 new engineers into India's markets, ${ }^{148}$ who are articulate English speakers which is another aspect of India's better position to attract more foreign direct investment. ${ }^{149}$ Needless to say India's substantially more stable political platform compared to other developing countries sketches India as a good investee, ${ }^{150}$ as Luna especially stressed in his note. ${ }^{151}$ These factors represent some of the main considerations for foreign direct investment.

The aforementioned economic characteristics can also teach of the potential the Indian population to afford patented drug in the future. ${ }^{152}$ As Beinhocker and Zainulbhai project, by the year 2025, private spending in India will increase to 62 per cent. ${ }^{153}$ Reviewing India's past progression, since 1991, when the Indian economy reform was forced to attract more foreign direct investment to the local markets, there were 431 million people saved from poverty and entered the middle economic class, with substantial higher purchasing power. ${ }^{154}$ In two decades time, Beinhocker and Zainulbhai foresee increase in private consumption from 7 per cent to 20 per cent, ${ }^{155}$ mostly in health and education ${ }^{156}$ and with an annual domestic product growth of 7.3 per cent, the authors also project another 465 million people existing in poverty, ${ }^{157}$ which would represent a 26 per cent decrease of rural poverty. ${ }^{158}$ Hence, it can be assumed that the future unrecognisable Indian middle class ${ }^{159}$ would be capable of drug purchasing in time of need, especially with the suggested wide ranged competitive Indian pharmaceutical marketplace.

\footnotetext{
countries, pharmaceutical multinationals would continue to invest and collaborate with the Indian pharmaceutical industry. See also Lanjouw, above n 121, 27.

${ }_{147}$ See generally Luna, above n 140, 38.

${ }^{148}$ Baker, above n 121, 395.

${ }^{149}$ See Luna above, n 140, 36. Compare Baker, above n 121, 397.

${ }^{150}$ See generally Luna, above n 140, 39.

151 Ibid, 39.

${ }^{152}$ See Beinhocker, Zainulbhai, above n 139, 51.

153 Ibid, 56.

${ }^{154}$ Ibid, 54.

${ }^{155}$ Ibid, 57.

156 Ibid, $58-59$.

${ }^{157}$ Inid, 54.

${ }^{158}$ Ibid, 54 - 55. The authors did not dismiss the remaining challenges which still can hinder the economic growth in India as the slow urbanised growth in compare to other Asian economies as China. However they still emphasised that exiting from poverty is a reality in India.

${ }^{159}$ Ibid, 56.
} 
In addition to the economic platform, another attractive characteristic of high foreign direct investment inflows is India's evolving pharmaceutical industry. Luna emphasised the Indian pharmaceutical industry, stressing its comparative advantage in basic organic chemicals and information technology. ${ }^{160}$ The unique features of the Indian current pharmaceutical industry is next reviewed to complete its suitability to enjoy high rates of foreign investment.

\section{The Indian pharmaceutical industry}

One can find a wide consensus regarding the rapid progress the Indian pharmaceutical industry has made in the past four decades, since it omitted patent protection from pharmaceutical products and encouraged larger generic production. ${ }^{161}$ India has build up considerable sophisticated imitative capabilities through generic practicing ${ }^{162}$ and as of today, India is rated fourth in sales and volume of pharmaceuticals and 13 in terms of value. ${ }^{163}$ The rapid growth of capabilities, both in technical and business skills to adapt to the United States and European markets was also stressed by Bower and Sulej, to show appreciation for the Indian pharmaceutical industry progression. ${ }^{164}$

Chataway emphasised the advancement of the Indian pharmaceutical research and development skills, ${ }^{165}$ stating that by the end of the 1990s leading Indian pharmaceutical firms had established innovative capabilities and exporting competitiveness. ${ }^{166}$ According to the authors, India's transformation from generics commodity to establishing research and development based multinational was a precedent of all times. ${ }^{167}$ There was not any evidence of similar progression, not even

\footnotetext{
${ }^{160}$ See Luna, above n 140, 39.

${ }^{161}$ See generally Sajeev Chandran, Roy Archana and Lokesh Jain "Implication of New Patent Regime on Indian Pharmaceutical Industry: Challenge and Oppertunities" (2005) 10 Journal of Intellectual Property Rights 269, 270.

${ }^{162}$ See Chataway, Tait and Wield, above n 107, 697, 705.

${ }^{163}$ See Chandran, Archana and Jain, above n 161, 269.

${ }^{164}$ See Jane D Bower, Julian C Sulej "The Indian Challenge: The Evolution of a Succesful New Global Strategy in the Pharmaceuticlka Industry" (2007) 19(5) Technology Analysis \& Strategic Management $611,611$.

${ }^{165}$ See Chataway, Tait and Wield, above n 107, 698.

${ }^{166}$ Ibid. See also Joanna Chataway, Dinar Kale and David Wield (editorial) "The Indian Pharmaceutical Industry Before and After TRIPS" (2007)19(5) Technology Analysis \& Strategic Management 559, 559.

${ }^{167}$ See Chataway, Tait and Wield, above n 107, 698 - 699. See also Chaturvedi, Chataway and Wield, above n $10,565,565$.
} 
in several industrialising developing countries as China, Cuba, Brazil, South Korea, and South Africa which also succeeded in building vast skills in chemical and biological research and development. ${ }^{168}$

Nevertheless, despite its progression, there is still much more "catching up" to do with the Western innovative pharmaceutical technologies. ${ }^{169}$ Although there are Indian firms which are incorporated with innovation, their number is still small and cannot establish a large pharmaceutical industry. There is a need to allocate small firms for innovative activity as well. ${ }^{170}$ The imperfect Indian innovative pharmaceutical industry is also exemplified by the poor investment it attracts, both by the private and the public sector. ${ }^{171}$ As of today, for every 1,000,000 people in India, there are only 156 available researchers ${ }^{172}$ and in comparison to China with 1.23 per cent investments of its gross domestic products in the pharmaceutical industry, the Indian Government invests only 0.8 per cent. ${ }^{173}$ The limited and skewed markets in India and the absence of stronger health infrastructure also contribute to the slothful research and development progression of the local pharmaceutical industry. ${ }^{174}$ Respectively under these elements and the weak private - public investment in research and development, as much as the Indian industry aspired to increase its innovative capacity, it did not as much as it could have. ${ }^{175}$ This is to be remedied by patent enforcement as suggested.

As Chaudhuri found in his research on the Indian innovative research and development trends, the Indian pharmaceutical industry traditionally does not spend considerable expenditure on research and development. ${ }^{176}$ Nevertheless, he did find growing trends in investment since the early years of 2000 s, especially by 28 major research and development firms. ${ }^{177}$ From 1.78 per cent in 1992-93, their investment

\footnotetext{
168 Ibid.

${ }^{169}$ See Chataway, Tait and Wield, above n 107, 702.

${ }^{170}$ See Lanjouw, above n 121, 28.

${ }^{171}$ See generally Chataway, Tait and Wield, above n 107, 702.

${ }^{172}$ Garde, above n 129, 21.

173 Ibid.

${ }^{174}$ See Chataway, Tait and Wield, above n 107, 698.

175 Ibid, 702.

${ }^{176}$ Supid Chaudhuri "Is Product Patent Protection Necessary in Developing Countries for Innovation? R\&D by Indian Pharmaceutical Companies after TRIPS" (Working paper, Indian Institute of Management Calcutta, 2007) 1,6-9.

${ }^{177}$ Ibid.
} 
increased to 3.86 per cent in 2001-02, sharply increased to 7.83 per cent in 2004-05 and further to 8.79 per cent in 2005-06. ${ }^{178}$ According to Chaudhuri, there are only nine firms whose investment in research and development increased over 10 per cent of their sales. ${ }^{179}$ The main aspects of the Indian firms' incompetence to invest in research and development has to do with lack of capital and lack of knowledge, two prime elements which can be answered by Western firms' support and collaboration. $^{180}$

Western pharmaceutical firms are desperately seeking for someone to share the risks entwined with pharmaceutical research and development. The research and development process can be exhausting and mostly expensive for the pharmaceutical industry. ${ }^{181}$ One way to reduce the cost of innovation is therefore through collaborating with Indian pharmaceutical firms which can offer low cost services of clinical trials the Western firms. ${ }^{182}$

Nevertheless, pharmaceutical multinationals still find India a difficult location for investment due to local complicated regulations and logistics. ${ }^{183}$ One of the challenges is the lack of wider patent protection enforcement and breached data protection. In a study of the World Bank on India's journey towards an effective patent system, it was concluded that with a broader patent protection enforcement, India will be able to receive more investment from pharmaceutical multinationals, benefit from new research and development facilities and from education, training and innovation spillovers. ${ }^{184}$ India just needs to expand its patent protection scope; it needs to enforce patent protection of the core level of innovation in the pharmaceutical technology field; ${ }^{185}$ otherwise it will soon suffer from a plateau of low innovative levels. ${ }^{186}$

\footnotetext{
${ }^{178}$ Ibid. See also Bower, Sulej, above n 164, 614-617.

${ }^{179}$ Chaudhuri, above n 176, 4. See also Biswajit Dhar, K M Gopakumar "Post-2005 TRIPS Scenario in Patent Protection in the Pharmaceutical Sector: The Case of the Generic Pharmaceutical Industry in India" (2006) 2,50 www.measwatch.org (13 Spetember, 2009).

${ }^{180}$ See generally Chataway, Tait and Wield, above n 107, 706.

${ }^{181}$ Ibid 700 - 701. See also part III A New Chemical Entities

182 See generally Chataway, Tait and Wield, above n 107, 700.

${ }^{183}$ Ibid 702.

${ }^{184}$ See generally Todaro, Smith, above n 11, 41.

${ }^{185}$ See Part VI A Patenting Pharmaceutical Incremental Innovation - a Prospect of a Better Healthcare.

${ }^{186}$ See generally Todaro, Smith, above n 11, 42.
} 
In this respect it is important to mention that the sensitive link between intellectual property and technology transfer is a stable connection which will not soon be broken. This reality emphasises the importance of the Indian Government's reassessment of its patent mechanism to include patenting of pharmaceutical incremental innovation. ${ }^{187}$ Should other factors which exceed foreign direct investment as tax incentives, workforce cost or Government stability, diminish, India would still be able to rely on a wide patent protection enforcement ${ }^{188}$ to motivate pharmaceutical multinationals investment. ${ }^{189}$

As of today, the innovation drive Indian pharmaceutical firms find, does not result from the national Government. Most vastly activated pharmaceutical firms in India, which can be counted to 10 , engage with innovation, only due to the collaboration that they find with Western firms. This option is not available to smaller sized Indian pharmaceutical firms which are lacking both the capital and the technological resources larger firms have which enable them to collaborate with the West. Hence, without regulation/government/market and health systems support, India will still suffer from weak competitive nature both in the local and the international market, ${ }^{190}$ which will push it to find a solution of low cost drugs only through generics.

As much as patent protection can be blamed for high drugs pricing, it should not be blamed alone. India's Government's decreasing control over drugs pricing regulations and orders is another influential factor on the high price of drugs in India. Unfortunately although there is no limitation on price control orders in the TRIPS Agreement, not all drugs in the Indian market are regularised. ${ }^{191}$ Moreover most of the essential drugs under the World Health Organisation essential drug list are not protected under the drug price control in India. ${ }^{192}$ Medicine for HIV, cancer, coronary artery disease, vaccines for rabies, anaemia and more, are not protected by price control orders. ${ }^{193}$ In a country whose population is not protected by universal health

\footnotetext{
${ }^{187}$ See Garde, above n 129, 23.

${ }^{188}$ See generally Baker, above n 121, 400.

${ }^{189}$ Ibid. See also Garde, above n 129, 23.

${ }^{190}$ See generally Chataway, Tait and Wield, above n 107, 706-707.

${ }^{191}$ See Drug Prices and Affordability, above n 23. See also Prantik Garai "Patent Amendment Act 2005: Its Effect on Indian Pharmaceutical Company" (Working paper, West Bengal National University of Juridical Sciences, 2009).

${ }^{192}$ Ibid.

${ }^{193}$ Ibid.
} 
insurances, this status can be fatal. ${ }^{194}$ Under this reality how would the average labour worker in India, which makes only 60 Rs per day, purchase one course of Letrozole, a drug which treats cancer in the sum of 181.50 Rs? ${ }^{195}$

Nevertheless the high priced patented drugs, the All-India Drug Action Network, a Campaign Group for Rational Drug Therapy and Policy did not support the exclusion of patent enforcement on pharmaceutical innovation and ended its 2008 report by saying that "all these are not against TRIPS in anyway". ${ }^{196}$ Instead, acknowledging the drug prices distortion results in the Indian pharmaceutical industry, the group calls for a pro-active approach by the Indian Government to enforce various programmes price regularity of medicines as it did with cell phones, insurances premium and more. ${ }^{197}$ In other words the group reached the conclusion that a needed balance between patent enforcement and the Indian Government drug price regulations is needed to offer affordable drugs to the local population, and in any case not by narrowing the patent protection scope.

The potential of patent as a drug accessibility enabler can be supported if implemented in the Indian pharmaceutical industry on a wide scope platform. Reviewing India's economic features, its current status in the world's economic outline, its unique skilled scientific workforce, all show that India can bear the cost of introducing patent protection of pharmaceuticals and benefit from patent's encouragement of more extensive innovative activity. However, the Government involvement is still much needed to offer the proper balance between patent enforcement and the high prices of drugs, one which will not deter the pharmaceutical industry from innovating and at the same time be realistic to the purchasing power of the average Indian. This mission would not be as difficult as one may perceive, especially facing the new economic dawn of the Indian market.

Although the chronological process of utilising patent enforcement to enable better drugs routes in developing countries as presented, lays down the needed course of action, there is a need for a deeper observation of the different steps this course

\footnotetext{
${ }^{194}$ See generally Drug Prices and Affordability, above n 23.

${ }^{195}$ Ibid.

${ }^{196}$ Ibid emphasis added.

${ }^{197}$ Ibid.
} 
includes. The preliminary avenue needed is the one which asks what the pharmaceutical industry is, what levels of innovation it includes and whether there is another way to promise drug innovation besides patent enforcement. Only after answering these questions in a comprehensive manner, further rationales are given to support patent enforcement in developing countries as an opportunity of low cost drug market in contrast to the common perception. 


\section{PATENT AS A PRIME MOTIVATOR OF PHARMCEUTICAL INNOVATION}

In the fight against cancer, new medicines are responsible for the increase in longevity by $50-60$ per cent. ${ }^{198}$ Statistics show that by the year 2000 the world wide survival rate from cancer rose to 68 per cent. ${ }^{199}$ In 200812 significant treatment advances were discovered to treat the disease, including of nine new medicines. ${ }^{200}$ This group of 12 treatments included discoveries such as incremental innovated drugs, new use of an existing medicine or new benefits of a medicine or new approved medicines. $^{201}$

Since the discovery of the HIV/AIDS in 1988, 30 drugs have been approved for treatment by the Food and Drug Administration in the United States. ${ }^{202}$ Different periodicals publish discoveries of new drugs which have shown signs for optimism. In 2007, 92 drugs were tested to prevent HIV/AIDS and other related conditions ${ }^{203}$ and by the late 2008, two new pioneer drugs were approved. ${ }^{204}$ However the amount of the drugs still needed and the statistics of the immense death rates, testify how far we are from finding a cure for this fatal disease. In 2007, there were 33 million people living with HIV virus, inclusive of 2.7 million newly infected. ${ }^{205}$ In that year, AIDS caused the death of 2 million people. ${ }^{206}$ With new diseases emerging and the constant death from existing diseases, clearly pharmaceutical research and development is far from being completed.

In this respect and in a try to encourage further innovation, patent market exclusivity mechanism hinders many risks the pharmaceutical industry is facing during the drug development process, risks which can paralyse the innovative activity of the industry and, as a result, burden us all with potentially curable diseases.

\footnotetext{
${ }^{198}$ See Frank R Lichtenberg "The Expanding Pharmaceutical Arsenal in the War on Cancer" (2004) 2, 2 www.nber.org (accessed 18 November 2008).

199 Ibid, 21.

${ }^{200}$ See Clinical Cancer Advances 2008: Major Research Advances in Cancer Treatment, Prevention and Screening (2008) 3, 4 www.cancer.net (accessed 17 March 2009).

201 Ibid.

${ }^{202}$ See HIV/AIDS - 20 Years of Progress www.innovation.org (accessed 18 November 2008).

${ }^{203}$ Ibid.

204 Ibid.

${ }^{205}$ See UNAIDS/WHO 2008 Report On The Global AIDS Epidemic (WHO, Geneva, 2008) 30, 32.

${ }^{206}$ Ibid, 30.
} 
Following a review of the spectrum of pharmaceutical innovation, this chapter reviews the different factors that threaten it, starting from the cost of the research and development process to the intense competition which exists in the industry even before drugs are exposed to generic production. In other words this chapter lays the justifications of patent as an existential force to the pharmaceutical industry ${ }^{207}$ and explains why pharmaceutical firms refuse to develop new drugs without patent's comprehensive protection. $^{208}$

Based on early research in the 1980 s conducted by Mansfield, ${ }^{209}$ patent can be declared as a prime element in the pharmaceutical and chemical industries' innovative activity. ${ }^{210}$ Based on surveys and analysis of 100 United States manufacturing large firms, Mansfield concluded that in comparison to many other industries as metals, electrical, motor vehicles, rubber, and more, patent increases innovation more in the pharmaceutical and the chemical industries. ${ }^{211}$ To clarify the importance of patent as an innovative motivator, Mansfield found that even in the aforementioned industries which have very limited reliance on patent, the bulk patentable products were under patent protection. ${ }^{212}$ Examining the result in the motor vehicles industry, where patent is not as needed to motivate innovation as in the pharmaceutical industry, 60 per cent of the patentable inventions were patented. ${ }^{213}$ Hence, even in industries which do not need to rely on patent as a motivator, its protection is preferred and that can teach of its importance to encourage innovation all the more in the pharmaceutical technology field.

Considering the complexity of drug research and development process, one cannot claim against the legitimacy of a pharmaceutical firm's inclination towards patent protection given its prevention of free -riding. Although the industry is involved with life saving products, it counts as any other industry on an economical quid pro quo

\footnotetext{
${ }^{207}$ See generally Peter Barton Hutt "The Importance of Patent Term Restoration to Pharmaceutical Innovation" (1982)1(2) Health Affair 6, 12-13. See also Bessen, Meurer, above n 9. See also Rebecca S Eisenberg "The Problem of New Uses" (2005) 2 Yale J Health Pol'y L \& Ethics 717, 720-721.

${ }^{208}$ See generally Bessen, Michael, above n 9, 88-89.

${ }^{209}$ Edwin Mansfield "Patents and Innovation: An Empirical Study" (1986) 32(2) Management Science 173.

${ }^{210}$ Ibid, 174-175, 180.

${ }^{211}$ Ibid.

${ }^{212}$ Ibid, 180.

${ }^{213}$ Ibid.
} 
mechanism to create an incentive for its activity. The changing environment of the pharmaceutical industry, the competition risk, the long and costly research and development process, all emphasises the importance of the market exclusivity patent offers to the pharmaceutical innovator and the role it plays as a catalyst to the drug discovery process.

The pharmaceutical platform, chemical or biological, can be divided into two levels of innovation. One level can be based on an entirely new chemical or molecular entity. The Food and Drug Administration in the United States defines new molecular entity drug as a drug which contains an active substance which has never been approved in the market of the United States before. ${ }^{214}$ A new chemical entity is therefore a drug which is based on new chemical compound or structure. Of course the end of the pharmaceutical industry is to research for new chemical or molecular entities given that these forms hold more superior therapeutic response and thus potentially higher economic returns. The secondary level is incremental, which is based on an already existing drug and can offer better therapeutic references than the original. The incremental innovation, although involved with a lower bar of development, is the core level of the pharmaceutical technology innovation platform. ${ }^{215}$ Either level of innovation, pioneer or incremental, the pharmaceutical industry relies on patent as a prime tool to deter the copying risk involved with their innovation process.

A new patented drug with marketing approval by the Food and Drug Administration introduced to the marketplace is commonly referred to as a brand name drug. ${ }^{216} \mathrm{~A}$ breakthrough drug is the first brand name drug to use a particular therapeutic mechanism of treatment of a given diseases. ${ }^{217}$ In comparison, a generic drug is a copy of the brand name drug which contains the same active ingredients, in

\footnotetext{
${ }^{214}$ See The Food and Drug Administration [FDA] www.fda.gov/cder/dsn/factsheet (accessed 8 October 2008).

${ }^{215}$ See Parama S Palit, Bhaskar Bhattacharya "Does Intellectual Property Laws in Indian and China Encourage Innovation?” (2008) 4(3) 日本知財学会誌 [Journal of Intellectual Property Law of Japan] $82,83$.

${ }^{216}$ The Congress of the United States How Increased Competition from Generic Drugs Has Affected Prices and Returns in the Pharmaceutical Industry (Washington DC, 1998).

${ }^{217}$ Ibid.
} 
terms of strength, quality and therapeutic effectiveness. ${ }^{218}$ It can be concluded that there are two competitors who compete between themselves and against each other in the pharmaceutical industry: the brand name pharmaceutical innovators and the generic producers. ${ }^{219}$

\section{A. New Chemical Entities}

Synthesising a new chemical entity substance of an approved drug takes about 12.8 years on average. ${ }^{220}$ After understanding the disease and finding the biological target, the drug's molecule and testing it on animals (pre-clinical trials stage), ${ }^{221}$ the pharmaceutical firm conducts a three phase clinical trial on thousands of participants. $^{222}$ Nevertheless, finding a successful drug is not enough. The next step to putting a drug on the market shelf is the application for the drug's approval by the different regulators such as the Food and Drug Administration in the United States, which approves the drug's marketing and distributing. ${ }^{223}$

Studies show that the average length of processing a new drug application in the Food and Drug Administration is up to 10 years. ${ }^{224}$ Applying to the Food and Drug Administration does not mean an automatic approval of the new drug application. ${ }^{225}$ Often the regulator over marketing drugs may need of more research and further testing before granting the innovator pharmaceutical firm with marketing approval. ${ }^{226}$ There are even times when the regulator denies the application without giving the applicant any chance of alteration. ${ }^{227}$

\footnotetext{
${ }^{218}$ Ibid. See also Facts and Myths about Generic Drugs www.fda.gov (accessed 8 October 2008).

${ }^{219}$ See generally Michael Dickson, Jean Paul Gagnon "The Cost of New Drug Discovery and Development" (2004) 4(22) Discovery Medicine 172, 174-175. See also Tomas J Philipson, Carolanne Dai "Between - vs. Within -Patent Competition" (2003) Regulation 42, 43. See also Competition in the Pharmaceutical Marketplace (2002) 2, 7 www.ftc.gov (accessed 11 November 2008).

${ }^{220}$ See Generally Dickson, Gagnon, above n 219, 172-173.

${ }^{221}$ See generally Profile 2008 Pharmaceutical Industry (2008) IV, 4 www.amsa.org/business/2008Profile_(accessed 11 November 2008). It is important to note that according to the pharmaceutical industry statistics, pre-clinical trials tests cost is constantly increases. ${ }^{222}$ Ibid, 5 .

${ }^{223}$ Ibid.

${ }^{224}$ See generally Dickson, Gagnon, above n 219, 172-173.

${ }^{225}$ See generally Profile 2008 Pharmaceutical Industry, above n 221, 5.

${ }^{226}$ Ibid.

${ }^{227}$ Ibid.
} 
Notwithstanding the approval of the Food and Drug Administration, the pharmaceutical firm is still obliged to conduct testing of the patented drug and continue to report to the regulator on the drug's therapeutic efficacy and its adverse effects on consumers. ${ }^{228}$ This obligation is perceived as the fourth stage the pharmaceutical firms have to go through before freely passing the innovated drug to the marketplace. ${ }^{229}$ The indefinite approval from the Food and Drug Administration can be much more threatening for the pharmaceutical industry. Non-approved new drug application by the Food and Drug Administration means the loss of millions of dollars the pharmaceutical firm could use for different drug research, some which might have resulted in the next breakthrough treatment.

This reality is substantial. According to statistics taken from the pharmaceutical industry database in the United States, for every 5000 to 10,000 chemical compounds tested, only five make it to the clinical trials stage and only one drug will be approved by the Food and Drug Administration. ${ }^{230}$ This outcome testifies of the grave losses the pharmaceutical industry faces daily, losses which could have been attributed to different and maybe more successful research.

The long time it takes to introduce a drug to the marketplace leading to the first risk patent can deter through market exclusivity. With so many innovative pharmaceutical firms in the global industry, ${ }^{231}$ the possibility that two or more brand name researchers firms would apply to the Food and Drug Administration in the United States, to approve the same chemical compound, is high. ${ }^{232}$ Even if not the same, firms can still develop a different chemical compound which treats the same health condition, ${ }^{233}$ or uses a different process ${ }^{234}$ or even changes the compound

\footnotetext{
${ }^{228}$ Ibid.

${ }^{229}$ Ibid.

${ }^{230}$ See generally Profile 2008 Pharmaceutical Industry, above n 221, 6.

${ }^{231}$ See generally Lindsay Bruce (Guest Editorial) "Defending Value and Maximising Profitability of Innovative Pharmaceuticals over Their Entire Life Cycles" (2003) 3(3) International Journal of Medical Marketing 195,195-196.

${ }^{232}$ See generally Dickson, Gagnon abovd n 219, 174-176. See also Philipson, Dai, above n 219, 42. See also Henrey G Grabowski, John Vernon "The Distribution of Sales Revenues from Pharmceuticals Innovation" (2000) 18(1) Pharmacoeconomics 21, 24. The authors stressed the grave risks ahead the pharmaceutical industry as extensive competition, in addition to other factors as unforeseen clinical trials result and regulatory barriers, as prime considerations which affect the economic prospect of a drug during its development.

${ }^{233}$ Ibid. See also Competition in the Pharmaceutical Marketplace, above n 219.

${ }^{234}$ See generally The Congress of the United States, above n 216.
} 
enough to make it appear to be a new form of the drug (a key level of innovation in the pharmaceutical industry through incremental innovation). ${ }^{235}$

This competitive phenomenon is called between - patent competition. ${ }^{236}$ Tomas and Dai stressed the gravity of between-patent competition to the innovative returns expected by the pharmaceutical industry for the superior products which enter the marketplace. ${ }^{237}$ The authors found that throughout the first 16 years of patent protection term, between-patent competition can lead to a substantial reduction in the returns expected from selling the patented drug in the marketplace, even more than the effect of within-patent competition which represents the competition between the pharmaceutical innovators and the generic producers which takes place at the end of patent term protection. ${ }^{238}$

In any case the competition and the threat on a firm's market superiority are substantial. Without exclusive control over the chemical compound at its early stage of development, the "first to innovate" firm's investment would be wasted. Under the patent market exclusivity mechanism, once a pharmaceutical firm invents a new compound with novelty elements and usefulness application, it can ask for patent protection and enjoy an early market exclusivity position to deter competitors from using or copying its costly invention. ${ }^{239}$ For this reason it is common in the pharmaceutical industry for a firm to apply for patent protection before the clinical trial stage begins ${ }^{240}$ to enjoy "safe ground" to examine and develop the chemical compound without stressful competition.

The risk of losing US\$1 billion investment due to the fact that another secondary firm invented a competitive chemical compound seems to be an extremely frightening image for the original pharmaceutical firm innovator. ${ }^{241}$ Yes, the research and development process within the pharmaceutical industry can cost billions of dollars.

\footnotetext{
235 Ibid.

${ }^{236}$ See generally Philipson, Dai, above n 219, 43.

${ }^{237}$ Ibid, 42, 45-46.

${ }^{238}$ Ibid.

${ }^{239}$ See TRIPS Agreement, above n 1, art 27(1).

${ }^{240}$ See generally Frederic M Scherer "The Pharmaceutical Industry - Prices and Progress" (2004) 351(9) The New England Journal of Medicine 927, 927. See also David Henry, Joel Lexchin "The Pharmaceutical Industry as a Medicine Provider" (2002) 360 The Lancet 1590, 1593.

${ }^{241}$ See DiMasi, Grabowski, above n 8, 475.
} 
DiMasi and colleagues found that the pre-tax cost of research and development of a new chemical entity drug in dollars value in 2000 can reach to US\$802 million. ${ }^{242}$ Into this figure, DiMasi and colleagues included the success and the failure rates in getting the Food and Drug Administration's approval. ${ }^{243}$ However, it does not include the cost of marketing, distribution, sales taxes which also represent a great part of a drug's cost. ${ }^{244}$ Once the marketing expenditures are added, DiMasi and colleagues found that the cost of research and development of a drug can reach US\$900 million. ${ }^{245}$ In a different study DiMasi found that the process of research and development in the biopharmaceutical technology field, which is based on biological substances, ${ }^{246}$ can reach to over a US\$1 billion. ${ }^{247}$

Apparently these numbers represent only the beginning. Aiming to test the drug on a wide range of people, the expectation to demonstrate therapeutic effectiveness ${ }^{248}$ and the advancements in basic science often demand a longer and more expensive process of research and development. ${ }^{249}$ Another factor is the fact that many viruses build some sort of resistance to drugs and transform to chronic diseases. Given that chronic diseases demand a longer term of drug use, researching the drug and applying it to the use of human beings will naturally require longer research process and thus more expenditure investment. ${ }^{250}$

These economic figures only stress that without marketing exclusivity and with an extensive competition in the pharmaceutical industry, firms would not be able to

\footnotetext{
${ }^{242}$ See Joseph A DiMasi, Ronald W Hansen and Henry G Grabowski "The Price of Innovation: New Estimates of Drug Development Costs" (2003) 22 Journal of Health Economics 151,153.

${ }^{243}$ Ibid, 156. See also Christopher P Adams, Van V Brantner "Estimating the Cost of New Drug Development: Is it really \$802 Millions?" (2006) Health Affairs 25(2) 420, 424-427. But see Scherer, above $n$ 240, 928.

${ }^{244}$ See generally DiMasi, Hansen and Grabowski, above n 242, 180.

${ }^{245}$ Ibid. See also Scherer, above n 240, 928. Scherer also noted the high expenditure needed in the process of marketing. But see Henry, Lexchin, above n 240, 1591. Nevertheless it is important to mention that marketing is part of the cycle. Without investing in marketing, the pharmaceutical industry may not attract as many consumers as needed to return its investment and that will prevent it from allocating the needed capital to invest in future research and development and drug discovery.

${ }^{246}$ See generally Gary Walsh Biopharmaceuticals Biochemistry and Biotechnology (2ed, John Wiley \& Sons Ltd, Chichester, 2003) $1-2$.

${ }^{247}$ See DiMasi, Grabowski, above n 8, 475. See also Dean, above n 82, 726.

${ }^{248}$ See generally Kenneth I Kaitin, Joseph A DiMasi "Measuring the Pace of New Drug Development in the User Fee Era" (2000) 34 Drug Information Journal 673,673.

${ }^{249}$ Ibid. See also The Congress of the United States, Research and Development in the Pharmaceutical Industry (Washington DC, 2006). See also DiMasi, Hansen, Grabowski, above n 242, 181-182.

${ }^{250}$ See generally Kaitin, DiMasi, above n 248, 674.
} 
recoup their investment of the costly research and development process. In this regard it is worthwhile to emphasise that the process of discovering new drugs, research and develop them, is mostly financed by the private sector. ${ }^{251}$ Therefore, with the public's expectation from the pharmaceutical industry to fund the research and development process, it needs to allow the industry a way to recoup its investment to continue and conduct further research and answer its demands. ${ }^{252}$

The pharmaceutical innovative industry is also competing with the generic industry. In the pre-TRIPS Agreement era, hence, prior to the year 1995, developing countries such as India copied patented drugs and sold them cheaply. These countries did not offer patent protection on pharmaceutical products and once a new drug was introduced to the market, the generic industry could copy the drug and sell it in low cost. Although under the Indian legislative frame this enactment was legitimate, it was not in cooperation with the developed world practices offering patent protection for 20 years. Needless to say the competition the generic industry has imposed on the brand -name drug markets was a growing burden on pharmaceutical firms' ability to recoup their costly investment in the process of research and development. ${ }^{253}$ However, as of today, under the TRIPS Agreement, generic firms' practices are delayed to the end of 20 years protection term. Nevertheless, to be mentioned is the fact that the competition the generic industry raises has still an immense impact on the pharmaceutical industry ability to recoup its investment in drug innovation given its low cost rates.

One prime example of the grave impact generic production has on brand name drug costs is the case of the antiretroviral drugs combination to treat HIV/AIDS in Australia. According to Henry, the generic production of the drug required the brandname drug owner to reduce the price of the drug by 97 per cent. ${ }^{254}$ Undoubtedly, reduction of prices, even at the end of the patent term, due to generic competition can prevent the pharmaceutical firm from recouping its investment. The generic industry

\footnotetext{
${ }^{251}$ See generally Dickson, Gagnon, above n 219, 178.

252 Ibid.

${ }^{253}$ See generally Dinar Kale, Steve Little "From Imitation to Innovation: The Evolution of R\&D Capabilities and Learning Processes in the Indian Pharmaceutical Industry" (2007) 19(5) Technology Analysis \& Strategic Management 589, 599 - 600. See also Part IV B Generics Fall and Innovation Rise.

${ }^{254}$ See Henry, Lexchin, above, n 240, 1592.
} 
has the ability to cause pharmaceutical firms to lose their market exclusivity substantially and affect the potential return of their investment. ${ }^{255}$ Often firms do not succeed in recouping their expenditures in the process of research and development during the patent protection term, ${ }^{256}$ a problem which is deepened by a generic industry activity.

If the impact so substantial at the end of the patent term, it is all the more substantial during the term of a patent protection. Hence, patent's promise of market exclusivity for the term of 20 years can at least give a suitable term for the pharmaceutical firm innovator to try and return its expenditures invested in the research and development process and answer the need of the public to continue and research in the future for better and more suitable therapeutic drug solutions to deadly diseases.

In other words, the long and costly research and development process, the chance of denial by the Food and Drug Administration or other regulator of the new drug application and the daily competition risks imposed on brand name drugs innovators can justify the pharmaceutical industry reliance on patent protection. These risks can show that relying on patent which offers marketing exclusivity is not a capricious requirement of the pharmaceutical industry, but the one promise the industry needs, to be able to develop life saving products and introduce them to the marketplace. Humanitarianism, unfortunately, is not economically sufficient to conduct research and development of drugs. As shown earlier, not even nations' government can, or wish to, vouch for pharmaceutical research capital resources and most of it is placed on the private sector. Research in the chemical and the pharmaceutical industry is costly and thus obliges the public to pay high prices for drugs. Nevertheless what good is there in cheap drugs if they are not effective or if they treat the wrong condition $?^{257}$ The pharmaceutical industry therefore needs the support and protection of market exclusivity, as it ultimately answers the need of the public for drugs.

\footnotetext{
${ }^{255}$ See generally Henry G Grabowski, Margaret Kyle "Generic Competition and Market Exclusivity Periods in Pharmaceuticals" (2007) 28 Managerial and Decision Economics 491, 496-498, 500-501. ${ }^{256}$ See generally Dickson, Gagnon, above n 219, 174.

${ }^{257}$ See generally Frederick M Abbott "Managing the Hydra: The Herculean Task of Ensuring Access to Essential Medicines" in Keith E Maskus, Jerome H. Reichman (eds) International Public Goods and Transfer of Technology Under Globalized Intellectual Property Regime (Cambridge University Press, New York, 2005), 395.
} 
The pharmaceutical industry's need of market exclusivity as the only adequate innovative platform, raise some expressions of patent as an insufficient tool to supply the industry the exclusiveness it needs. ${ }^{258}$ Although patent offers 20 years of market exclusivity, it appears often not to be enough for pharmaceutical firms in their trials to recoup their expenditures. ${ }^{259}$ Although there are drugs which are sold for billions of dollars, there are drugs which return only US\$25 million a year which often is not equal to the investment put into their research and development process. ${ }^{260}$ As mentioned, in order to obstruct competition, it is common for a firm to apply for patent protection at the early stage of the pre-clinical trials. ${ }^{261}$ This means that after an average of 12.8 years of research and development process in addition to the time it gets for the drug to be approved for marketing by the Food and Drug Administration regulators, a pharmaceutical firm is left with no more than eight to nine years of marketing the drug in a try to return its investments.

With a shorter exclusivity time in the marketplace for marketing, the chances of the pharmaceutical firm to recoup its investment become leaner. Also a firm's product pipeline is not as full as it was in the past. ${ }^{262}$ There is a fear that new drugs' discovery will not be as fruitful as before. ${ }^{263}$ Not only does it become more difficult to discover new chemical entities, according to Bruce, but it is estimated that by the year 2015, the 'blockbuster' drugs will be off patent and thus free for copying and cheaper marketing by the generic industry. ${ }^{264}$ According to Dickson unless firms are constantly engaged with new chemical entity based drugs, which is known as extremely difficult, the funds to support future research will be insufficiently small ${ }^{265}$ and leave society with not assuring health care future. ${ }^{266}$ This scenario as Bruce analysed, brings pharmaceutical firms to rely more on their off-patented existing drug products in the sense that they will have to answer the need of a pharmaceutical firm

\footnotetext{
${ }^{258}$ See generally Dickson, Gagnon, above n 219, 174. See also Bruce, above n 231, 195.

259 Ibid.

${ }^{260}$ See generally The Congress of the United States, above n 216.

${ }^{261}$ See generally Scherer, above n 240, 927. See also Henry, Lexchin, above n 240, 1593.

262 See generally Bruce, above n 231, 195.

${ }^{263}$ See Lanjouw, above n 121, 14.

${ }^{264}$ See Alka Chadha "Destination India: The Right Choice for the Pharmaceutical Industry" (2006)

7(1) Delhi Business Review 1, 2.

${ }^{265}$ See Dickson, Gagnon, above n 219, 174.

${ }^{266}$ Ibid.
} 
to allocate enough capital for further research. ${ }^{267}$ However, it can be presumed that the generic competition does not enable the fulfilment of this end.

For these reasons not only did Bruce stressed the importance of patent protection, she also encouraged firms to make the most out of the patent term and allow themselves to regain their investment as much as possible. ${ }^{268}$ Bruce suggested an extension of patent protection by filing secondary patents on drugs. ${ }^{269}$ In other words, following some adjustment and improvement of off-patent drugs pharmaceutical firms should be able to apply for patent protection on the original drugs' new versions. ${ }^{270}$ In other words, Bruce highly supported the patenting of incremental innovation. ${ }^{271}$ Nevertheless, although incremental innovation of an original drug can answer a tactical need of the pharmaceutical industry to try and fully recoup capital for future research, it is mostly a scientific core level of innovation in the pharmaceutical technology field. ${ }^{272}$ The next part of this chapter analyses the platform of pharmaceutical incremental innovation, its therapeutic and economic importance and the industry equal reliance on patent to motivate pharmaceutical incremental innovation.

\section{B. Incremental Pharmaceutical Innovation}

"Nature does nothing in leaps" ${ }^{273}$ neither does the pharmaceutical industry. ${ }^{274}$ Although the wheel can be considered as a "breakthrough" invention in the transportation industry as Palit and Bhattacharya noted, they also viewed that the industry could not have been revolutionised without the small supplementary inventions in the field. ${ }^{275}$ Incremental innovation is perceived in the same manner in

\footnotetext{
${ }^{267}$ See Bruce, above n 231, 195. See also Henry, Lexchin, above n 240, 1590.

${ }^{268}$ See Bruce, above n 231, 195 - 196.

269 Ibid.

270 Ibid.

${ }^{271}$ Ibid.

${ }^{272}$ See Pharmacoevolution: The Advantages of Incremental Innovation www.who.int/intellectualproperty/submissions (accessed 2 February 2009).

${ }^{273}$ See Palit, Bhattacharya, above n 215, 83.

${ }^{274}$ See Albert Wertheimer, Richard Levy and Thomas W O`Connor "Too Many Drugs? The Clinical and Economic Value of Incremental Innovation" in Irina Farquhar, Kent Summers and Alan Sorkin (eds) Research in Human Capital and Developmemt Investing in Health: The Social and Economic Benefits of Health Care Innovation (vol 14, Elsevier Science, Oxford, 2001) 79.

${ }^{275}$ See Palit, Bhattacharya, above n 215, 83.
} 
the pharmaceutical industry. ${ }^{276}$ The pharmaceutical innovation process does not get any faster and every small step could lead to a giant therapeutic leap. As the incremental innovation level relies on the same elements of research and development as the new chemical entity drug, and suffer from the same risks (even higher risks for its simpler elements, which are easily innovated), the pharmaceutical industry sees great importance in patent protection of incremental innovation. ${ }^{277}$

Pharmacologically, incremental drugs are "new drugs in an already existing class which has a similar mechanism of action as the first-in-class, but differ in features such as, therapeutic profile, metabolism, adverse effects, dosing schedules, delivery systems... ${ }^{278}$ In other words, incremental development could be a drug which can offer better chances of tolerability and fewer side effects, features which are often vital in different treatments. ${ }^{279}$ In this respect incremental innovation can offer a substitutive therapeutic solution to drugs which are taken off the market shelf if found damaging or insufficient. ${ }^{280}$ Incremental development can offer different doses of drugs, enable longer use of drugs by a larger variety of consumers, ${ }^{281}$ and reduce the social cost of use of hospitals. ${ }^{282}$

With many drugs taken off the market shelves, or patients who find that they cannot consume the drugs due to poor bioavailability (the drug's absorption in the blood $)^{283}$ or severe side effects, incremental development offer new possibilities. ${ }^{284}$ Through different application to treat side effects and better and easier ways to use the drug, incremental drugs can be perceived as fitting the different consumer individuals. ${ }^{285}$ As noted by Wertheimer, Levy and O`Connor "the public benefits are

\footnotetext{
${ }^{276}$ Ibid. See also Wertheimer, Levy and O`Connor, above n 274, 78.

277 See Wertheimer, Levy and O Connor, above n 274, 110.

${ }^{278}$ Global Public Policy Issues, GlaxoSmithKline's Position "Incremental Innovation” www.gsk.com (accessed 2 February 2009).

${ }^{279}$ Ibid. See also Wertheimer, Levy and O`Connor, above n 274, 78.

${ }^{280}$ See Wertheimer, Levy and O`Connor, above n 274, 81.

${ }^{281}$ Ibid, 81, 83-86.

282 Ibid, 82, 100-107.

${ }^{283}$ Bioavailability is defined as: "[T] he proportion of a drug which reaches its site of Pharmacological activity when introduced into the body; more loosely, that proportion of any substance so introduced which enters the circulation" See Oxford English Dictionary Online, http://dictionary.oed.com (accessed 2 February 2009).

${ }^{284}$ See Pharmacoevolution: The Advantages of Incremental Innovation, above n 272.

${ }^{285}$ See Wertheimer, Levy and O`Connor, above n 274, 78, 86-98.
} 
striking because a broad class of drugs enables physicians to treat with precision the individual needs of diverse patients." 286

Effexor, an anti-depressive drug was incrementally developed by the American pharmaceutical firm Wyeth. ${ }^{287}$ Due to severe side effects detected in the drug soon after its marketing, Wyeth incrementally improved it and made it more tolerable for use. ${ }^{288}$ However, Effexor is only one example of many more drugs for which only their incremental evolvement enabled their marketing. Out of the essential drugs list of the World Health Organisation, half of the drugs are based on incremental improvement of their original compound form. ${ }^{289}$ These findings are critical to the understanding that the original breakthrough drugs do not remain the most effective forms and often their perfection is required through different classes.

Another example of the merits of pharmaceutical incremental innovation lies in the case of the antiretroviral drugs which treat infectious diseases, primarily HIV/AIDS. Due to many side effects of the antiretroviral drugs' combination and the intolerability consumers develop towards the drugs, pharmaceutical firms which are active in HIV/AIDS drug development have to constantly come up with new combinations to enable people to continue to fight the disease. ${ }^{290}$ In the fight of cancer, the situation is similar and drugs which treat cancer are constantly being incrementally developed. ${ }^{291}$

According to a survey conducted by the United States National Institute for Health Care Management, between the years 1989-2000, only 17 per cent of the pharmaceutical patents in the United States market were based on "drastic innovations" and 51 per cent designated to modifications of existing drugs. ${ }^{292}$ The pharmaceutical industry is dominated by incremental developments and naturally the

\footnotetext{
${ }^{286}$ Ibid, 80.

${ }^{287}$ Wyeth www.wyeth.com (accessed 2 February 2009).

${ }^{288}$ See The Importance of Incremental Innovation for Development (2005) 1, 10 www.iccwbo.org (accessed 2 February 2009).

${ }^{289}$ See Pharmacoevolution: The Advantages of Incremental Innovation, above n 272.

${ }^{290}$ See generally Wertheimer, Levy and O`Connor, above n 274, 81.

291 Ibid.

${ }^{292}$ Juan-Jose Ganuza, Gerard Llobet and Beatriz Dominguez "R\&D in the Pharmaceutical Industry: a World of Small Innovations" (2009) 55(4) Management Science 539, 539-540.
} 
propensity towards patent enforcement of this level of innovation is no different than the one it has in respect to new chemical entity based drugs.

Nevertheless, often the smaller level of innovation, in comparison to the new chemical entity drug development, raises some critiques to perceive incremental drugs only as "me too"drugs. ${ }^{293}$ In other words, these critiques see incremental innovation as drugs which are a repetitive form of its original version, ${ }^{294}$ which does not consist of enhanced therapeutic application and can cause unnecessary confusion for the medical community. ${ }^{295}$ Objecting to incremental pharmaceutical innovation on the grounds that it causes confusion indicates a simplistic perspective towards incremental innovation which does not fully consider the therapeutic merits of this level of innovation. ${ }^{296}$

As noted by Wertheimer, Levy and O`Connor "many pharmacological classes now contain numerous agents. Although these agents are molecularly similar, their therapeutic properties are often significantly different." ${ }^{297}$ Moreover, the greater the clinical choices are, the larger the group of patients receiving treatment is and the better is humanity health care. ${ }^{298}$ If the early version of a drug could not be marketed to the public due to severe side effects and its incremental form can, claims such as confusion seem to be misguided and if continued, can seriously hurt the chances of better health welfare future for the world's population. ${ }^{299}$

Although aspiring to develop the next "breakthrough" drug, for it has the largest prospectus of high sales rate, the majority of the pharmaceutical industry developments are still based on incremental improvements of existing drugs. ${ }^{300}$ In addition to the scientific justifications, the propensity of the pharmaceutical industry to incremental innovation lies in several economic avenues. With fewer breakthrough drugs introduced to the marketplace and the nearing end of patented drugs, the

\footnotetext{
${ }^{293}$ See generally Pharmacoevolution: The Advantages of Incremental Innovation, above n 272.

294 Ibid.

295 Ibid.

${ }^{296}$ See GlaxoSmithKline's Position “Incremental Innovation”, above n 278. See also Wertheimer, Levy and $\mathrm{O}^{`}$ Connor, above $\mathrm{n} 274,78$.

${ }^{297}$ See generally Wertheimer, Levy and O`Connor, above n 274, 80 .

298 Ibid.

299 Ibid, 78.

${ }^{300}$ Ibid, 109. See also See GlaxoSmithKline's Position "Incremental Innovation”, above n 278.
} 
pharmaceutical industry faces a deep capital predicament and a questionable innovative drud future. ${ }^{301}$ The industry is being pushed to expand its products' pipeline to include several innovative product groups such as generics, medical devices and of course modified drugs, in order to expand its economic platform. ${ }^{302}$

Needless to say, without a solid economic grounding, the industry would not be able to engage in further research and the global health care status would rapidly deteriorate. ${ }^{303}$ Patenting pharmaceutical incremental innovation can offer the industry a safe economic grounding as viewed by the International Chamber of Commerce. ${ }^{304}$ Incremental innovation research and development does not oblige the use of high expenditures as a new chemical entity drug does. ${ }^{305}$ It is less complex and thus has more chance to reach the marketplace. ${ }^{306}$ Incremental innovation is also involved with a shorter process of development and allows the industry to survive under the extensive competition in the marketplace. ${ }^{307}$ It can be thus concluded that the exclusion of pharmaceutical incremental innovation from the patent protection scope can deter the pharmaceutical industry from engaging in necessary innovation. ${ }^{308}$ The industry will not be able to engage in the costly drug discovery process without stable economic platform. ${ }^{309}$

In addition to the merits patenting incremental innovation offers to the pharmaceutical industry, it also offers the possibility of low cost patented drug in the marketplace. Encouraging incremental innovation in the pharmaceutical technology field can establish an extensive price reducing competition ${ }^{310}$ and if patented, a market of low cost patented drugs available to the poorer population of the world in developing countries. However, before analysing this option and examining the

\footnotetext{
${ }^{301}$ See generally Bruce, above n 231, 195.

${ }^{302}$ Ibid. See also Henry, Lexchin, above n 240, 1590.

${ }^{303}$ See generally Bruce, above n 231, 195.

${ }^{304}$ See The Importance of Incremental Innovation for Development, above $\mathrm{n} 288,1$.

305 See The Congress of the United States, above n 249. See also Henry, Lexchin, above n 240, 1592. See also Wertheimer, Levy and O`Connor, above n 274, 108109110.

${ }^{306}$ See Wertheimer, Levy and O`Connor, above n 274, 110.

${ }^{307}$ Ibid. See also Robert Weissman, "A Long Strange TRIPS: The Pharmaceutical Industry Drive to Harmonize Global Intellectual Property Rules, and the Remaining WTO Legal Alternatives Available to Third World Countries" (1996) 17 U Pa J Int'l Econ L 1069, 1075-1085.

${ }^{308}$ See generally Wertheimer, Levy and O`Connor, above n 274, 109 - 110.

${ }^{309}$ Ibid.

${ }^{310}$ See generally Joseph A DiMasi "A Price Trends for Prescription Pharmaceuticals: 1995-1999" (A Background Report Prepared for the Department of Health and Human Services Conference on Pharmaceutical Pricing Practices, Utilization and Costs, Washington DC, 8-9 August 2000).
} 
possibility of reducing drug prices through wide patent scope enforcement, it is of first importance to stress that this possibility was not always the case when India lacked pharmaceutical innovative skills.

Not so long ago, the Indian pharmaceutical industry was lacking sufficient innovative pharmaceutical skills. ${ }^{311}$ Not so long ago, the Indian pharmaceutical industry's drugs products were the most expensive in the international marketplace for it was fully controlled by foreign control patented drugs. ${ }^{312}$ Not so long ago, the Indian Government had to omit patent protection from pharmaceutical products in order to invite more generic production as the only way to access drugs. However time has changed. As time passed, not only has the Indian population benefited from lower cost drugs, but the Indian pharmaceutical industry has also benefited, for the process of reverse engineering equipped it with innovative research and development skills.

Although India's generic activity prior to signing the TRIPS Agreement tagged India as a pirate country, it did advance its pharmaceutical industry innovative skills. This is not to say that the thesis supports counterfeiting as a legitimate way to benefit a developing country's pharmaceutical industry innovative skills, rather to present the chronological background of the Indian pharmaceutical industry evolvement. Nevertheless, it should be noted that without any innovative skills, even minor, the prospect of establishing low cost patented drugs market, is small.

With respect to this, before examining how the new India of today can benefit from patent to create an affordable pharmaceutical marketplace, the next chapter shows the process India went through omitting patent protection from pharmaceuticals which advanced its generic industry and built innovative capabilities in the local industry. Only an innovative based pharmaceutical industry will find benefits from patent protection, for patents protect inventions. The next chapter therefore appreciates the growth of patent in India. Why did India fear patent? Were the benefits from generics in comparison to patent substantial? What ultimately led

\footnotetext{
${ }^{311}$ See Janice M Mueller “The Tiger Awakens: The Tumultuous Transformation of India's Patent System and the Rise of India Pharmaceutical Innovation” (2007) 68 U Pitt L Rev 491, 509.

${ }^{312}$ Ibid, 509-510.
} 
India to enforce the TRIPS Agreement and adopt patent protection for pharmaceuticals? Did the TRIPS oblige protection without any leniency towards developing countries' need to access drugs? Trying to answer these questions is of great importance and reviewing India's growth into patent, the next chapter analyses the preparation India has made towards embracing full patent protection for pharmaceutical products in the year 2005. 
IV GROWING INTO THE TRIPS - FROM GENERICS TO INNOVATION IN DEVELOPING COUNTRIES

\section{A. The Great Rise of Generics}

Under the colonial regime, the Indian pharmaceutical industry in the country was without any innovative skills. ${ }^{313}$ The wide patent policy dictated by Great Britain in India made the population rely mostly on imported products. ${ }^{314}$ That situation made India the most expensive market for pharmaceuticals in the world. ${ }^{315}$ Without any innovative capacity, ${ }^{316}$ the Indian population was left with no other choice but to rely on drugs offered in its marketplace. However, at that time India was one of the poorest countries in the world, ${ }^{317}$ and there was no use for these drugs as the local population simply could not afford them. ${ }^{318}$ This fact increased the death and sickness rates in the country. ${ }^{319}$ When India declared its independence in 1947 and freed itself from the control of the foreign regime of Britain, not much changed regarding its pharmaceutical innovative capabilities. ${ }^{320}$

It did not have the capital, the technologies or the knowledge to begin pharmaceutical innovation ${ }^{321}$ and in the meanwhile, the growing demand for low cost drugs increased rapidly. ${ }^{322}$ It is worth noting that India's poor economy caused the Government to resolve other human rights issues such as the right for housing, water and education as well. Of prime importance was the need for the Indian Government to cope with the growing rate of sickness and deaths in the country from treatable diseases.

Under the 1911 Indian Patents and Designs Act, both pharmaceutical processes and products inventions were eligible for patent protection for 16 years with an option

\footnotetext{
${ }^{313}$ See Martin J Adelman, Sonia Baldia "Prospects and Limits of the Patent Provision in the TRIPS Agreement: The Case of India” (1996) 29 Vand J Transnat'l L 507, 526.

314 Ibid.

315 See Mueller, above n 311, 509-510.

316 See Srividhya Ragavan "Of the Inequals of the Uruguay Round" (2006) 10 Marquette Intell Prop L Rev 273, 301.

317 See Mueller above, n 311, 509-510.

318 See Adelman, Baldia, above n 313, 526.

319 See John A Harrelson "TRIPS, Pharmaceutical Patents, and the HIV/AIDS Crisis: Finding the Proper Balance between Intellectual Property Rights and Compassion (2001) 7 Widener L Symp J 175, 176.

${ }^{320}$ See Mueller, above n 311, 509.

321 Ibid.

322 Ibid.
} 
to extend that term for an additional seven years. ${ }^{323}$ In comparison to pharmaceutical products which represent the final product of the drug, the pharmaceutical process was the drug's chemical course of development. ${ }^{324}$ As one would expect with a high percentage of poverty and minimal innovative skills, the scope of protection mainly serviced foreign applicants. India's local pharmaceutical industry did not have much need of patent protection. Patent encouragement of innovation cannot motivate an industry which lacks innovative orientation. On the contrary, India abolished patent for it hindered access to supremacy Western innovation like drugs. ${ }^{325}$

It took a while before the Indian pharmaceutical industry evolved. From 1947, from India's independence, until 1972 when the new Patents Act was introduced, there were very few Indian patents in the local market ${ }^{326}$ and pharmaceutical multinationals still held 90 per cent of the Indian marketplace. ${ }^{327}$ Given the poor and limited Indian purchasing power, 90 per cent of these patents were not even sold in India. ${ }^{328}$ The Indian population could not afford the patented products and thus the foreign rights' holders did not benefit from any Indian - sourced remuneration from sales.

Studies show that in 1974, 84 per cent of the issued patents in developing countries were under the hold of developed countries such as the United States, the United Kingdom and France. ${ }^{329}$ Only 1 per cent of patents were held by national patentees. ${ }^{330}$ This data indicates the little innovative capacity existed in developing countries inclusive of India in the years prior to the TRIPS Agreement. This inability can justify to some extent the irrelevancy of patent in such countries. Patent has the power to build an industry, but not an industry without any innovative capabilities. Limiting this statement is important for the fact that after India had gained progressive

\footnotetext{
${ }^{323}$ Ibid, 508.

${ }^{324}$ See The Congress of the United States, above n 216.

${ }^{325}$ See Mueller, above n 311, 491, 511 - 512. See also David Hindman "The Effect of Intellectual Property Regimes on Foreign Investment in Developing Countries” (2006) 23 Ariz J Int'l \& Comp L 467,489 .

${ }^{326}$ Garde, above n 129,8 .

${ }^{327}$ Ibid.

${ }^{328}$ Ibid.

${ }^{329}$ United Nations Department of Economics and Social Affairs The Role of the Patent System in the Transfer of Technology to Developing Countries (United Nations, New York, 1974).

${ }^{330}$ Ibid.
} 
innovative skills, the use of patent to encourage local innovation and empower the local industry is irreplaceable.

However, before analysing the new changed Indian pharmaceutical industry's capacity to contain patent, there is a need to understand why there was a necessity to omit patent protection from pharmaceutical products. Apparently, excluding patent enforcement from pharmaceutical products not only answered the need of the poor for affordable drugs, but introduced the Indian pharmaceutical industry to Western technologies, ones which prepared India to benefit from patent's mechanism in the following years.

Trying to answer its population growing need for affordable drugs and applying a reformed domestic production capacity, the Indian Government appointed two committees to review the local patent policy and adjust it to answer local needs and economy. ${ }^{331}$ The first report submitted to the Government was the report headed by the Justice Bakshi Tek Chand (Chand Report). ${ }^{332}$ The Chand Report did not recommend abolishing patent at whole, but to extend the use of compulsory licensing of the patented products. ${ }^{333}$ Compulsory licensing was one of the mechanisms which were inserted to the TRIPS Agreement in a try to answer the need of the poorer population of the world of patented drugs. ${ }^{334}$ Under the compulsory licensing mechanism India could generically produce patented drugs without remunerating the patentee as originally set. ${ }^{335}$

Although the Chand report brought some amendments to the 1911 Indian Patents and Designs Act, the extensive opposition to the use of compulsory license process by foreign rights' holders, diminished the use of this mechanism as a preliminary answer to the public needs. ${ }^{336}$ There was a need to find a solution from a different angle. The second report tried to offer that change. Headed by the Shri Justice N Rajagopala Ayyangar (Ayyangar Report), ${ }^{337}$ the Report offered much deeper reform. ${ }^{338}$ Firstly, it

\footnotetext{
${ }^{331}$ See generally Mueller, above n 311, 511.

332 Ibid.

${ }^{333}$ Ibid.

${ }^{334}$ See TRIPS Agreement, above n 1, art 31.

${ }^{335}$ See Part VI C Forming a Balance: Endorsing Wider Compulsory licensing utilisation in India.

${ }^{336}$ See Mueller, above n 311,511.

${ }^{337}$ Ibid.
} 
was concluded that one homogenous intellectual property mechanism was not an option and every country should create a mechanism to be fitted to its economic conditions. ${ }^{339}$ Following the vast condemnation of the local patent system and its irrelevancy to local innovative advancement, ${ }^{340}$ Ayyangar's Report secondly recommended narrowing patent protection from pharmaceuticals, chemicals and the food technology fields. ${ }^{341}$ The 16,000 licenses the local industry used in 1993, were a clear indication that patent had to be omitted to answer the consumers' needs for low cost products. $^{342}$

Excluding patent protection from pharmaceutical products as recommended in the Ayyangar Report was soon perceived as the leading step to making drugs affordable to the poor. Under the 1970 Indian Patents Act, the patentee was only allowed to enjoy protection of the innovated drug's process. ${ }^{343}$ This enabled the local generic industry to copy the patented drug through different processes. Using a different process to produce the innovated drug was therefore legitimate and enabled the industry to mass produce the patented drugs and sell them to the public at a low cost.

Given that the reverse engineering was considerably less costly than producing a new drug, both the private sector as well as the public laboratories focused on imitative research and development. ${ }^{344}$ Furthermore, with only seven years protection of the invented process by patent, ${ }^{345}$ the idea of patent was not as threatening as it was under the colonial regime. ${ }^{346}$ In reality, there was never a need to wait the entire seven years of the patent protection term to generically produce the drug. ${ }^{347}$ Finding an alternative process was rather a simple task. ${ }^{348}$

India was highly determined to promise better answers to the mass demand of drugs, and thus it did not even join the Paris Convention for the Protection of

\footnotetext{
${ }^{338}$ Ibid.

${ }^{339}$ Ibid.

${ }^{340}$ Ibid, $511-512$.

${ }^{341}$ Ibid, $512-513$

${ }^{342}$ See Garde, above n $129,9$.

${ }^{343}$ See The Patents Act 1970 (India), s 5.

${ }^{344}$ See Chaturvedi, Chataway and Weild, above n 10, 572.

${ }^{345}$ See The Patents Act 1970 (India), s 53.

${ }^{346}$ See Mueller, above n 311, 514.

${ }^{347}$ Ibid.

${ }^{348}$ Ibid.
} 
Industrial Property (Paris Convention) ${ }^{349}$ which enforced a much flexible intellectual property rights regime than the TRIPS Agreement does. ${ }^{350}$ Constituted as an early response to an internationally growing demand to enforce technology transfer and increase trade flows, the Paris Convention set the basis of industrialised property laws through minimum protection standards. ${ }^{351}$ According to the Paris Convention, signatory countries were free to pass any intellectual property laws they wished, as long as they did not discriminate the terms of protection against foreign inventors. ${ }^{352}$ Foreign applicants as nationals were to be treated the same. ${ }^{353}$ Under this obligation, signatory country to the Paris Convention which offered local inventors the opportunity to enjoy patent protection for a pharmaceuticals, product, process or both, had to offer the same protection to foreign pharmaceutical inventors.

In time when the demand for cheap drugs was substantially higher than today's, acknowledging foreign rights in the local market would not have answered that demand. It would have placed the Indian population under the same reality at the time of the colonial regime.

Therefore, many countries chose not to include patent protection over pharmaceutical products and some even excluded protection of pharmaceutical processes as well. ${ }^{354}$ Wishing to build solid industrialised markets, economy and consumption capacity, India did not want to be chained to foreign control over its market through strict intellectual property rights and chose not to become a signatory member to the Paris Convention. ${ }^{355}$

\footnotetext{
${ }^{349}$ Paris Convention for the Protection of Industrial Property revised at Stockholm, July 14, 1967, 24 UST 2140, TIAS No 7727,828 UNTS 305 [Paris Convention].

${ }^{350}$ See generally Susan K. Sell "Intellectual Property as a Trade Issue: From the Paris Convention to GATT” (1989) 13 Legal Stud F 407, 408.

${ }^{351}$ Ibid.

${ }^{352}$ See Paris Convention, above n 349, art 2. See also Frank Emmert "Intellectual Property in the Uruguay Round - Negotiating Strategies of the Western Industrialised Countries" (1989-1990) 11 Mich J Int'l L 1317, 1319 -1322.

${ }^{353}$ See Paris Convention, above n 349, art 4A. See also Sell, above n 350, 408.

${ }^{354}$ See generally Gerald J Mossinghoff "Research-Based Pharmceutical Companies: the Need for Improved Patent Protection Worldwide “(1987) 2 JL \& Tech 307.

${ }^{355}$ See Mueller, above n 311, 511-512. See also Adelman, Baldia, above n 313, 523.
} 
In addition to forming several research institutes and public pharmaceutical firms to produce generic drugs, ${ }^{356}$ India implemented different policies to reduce drugs' pricing in the market. This included the drug price control order. ${ }^{357}$ The control over prices of drugs was imposed through the restriction of prices, to cover only the cost of materials, formulation and distribution together with a limited level of profit. ${ }^{358}$ Nevertheless, despite the contribution of regularising drug pricing, the main cause to the cost reduction was the Patents Act 1970 and its abolishment of patent protection of pharmaceutical and chemical products. ${ }^{359}$ This abolishment enabled a wide ranged generic production activity which played a major role in reducing prices of drugs. A prime example of the generics efficacy is the effect it had on the cost of the antiretroviral drugs for HIV/AIDS.

Although an example from a later time, in 2001, the initial cost of the brand name triple therapy drug for HIV/AIDS was US $\$ 931 .{ }^{360}$ At the same time, when Cipla, one of India's prominent pharmaceutical companies ${ }^{361}$ declared it would offer the drug's generic version for US\$350 to Non-Governmental Organisations per year, the brandname drug's cost was reduced to US $\$ 727 .^{362}$ Following Cipla's declaration, Hetero, ${ }^{363}$ another Indian pharmaceutical firm, declared it would sell the drug for US $\$ 347^{364}$ and following Hetero's declaration, Randbaxy Laboratories, the largest pharmaceutical firm in India, declared it would sell the drug for US $\$ 295 .^{365}$ In 2005 , Hetero offered the drug's generic version in US\$152 against the US\$562 of the brand name drug. ${ }^{366}$ In total from 2001 to 2005 , the brand-name triple therapy drug's cost was reduced by 83 per cent due to generic competition. ${ }^{367}$ Not only patented drugs were offered in low cost in their generic versions, as many generic pharmaceutical firms competed

\footnotetext{
${ }^{356}$ See Kale, Little, above n 253, 595.

${ }^{357}$ See Chaturvedi, Chataway and Weild above n 10, 569. See also Kale, Little above n 253, 595.

${ }^{358}$ See Dhar, Gopakumar, above n 179, 50.

${ }^{359}$ See Mueller, above n 311, 513.

${ }^{360}$ Julien L Chaisse, Samira Guennif "Patent Political Economy - Indian Lessons on Pharmaceutical Patent" (2006) 1902 Bepress Legal Series 3, 8.

${ }^{361}$ See Cipla www.cipla.com/home (accessed 16 August 2009).

${ }^{362}$ Chaisse, Guennif, above n 360, 8-9.

${ }^{363}$ See Hetero Drugs Ltd www.heterodrugs.com (accessed 16 August 2009).

${ }^{364}$ Chaisse, Guennif above n 360, 9.

365 Ibid.

366 Ibid.

367 Ibid.
} 
with each other, the cost of the brand name drug was impacted and constantly reduced. $^{368}$

Needless to say this is only a fraction of the many examples of the influence of generics production on drugs' pricing reduction. As the Indian generic industry grew in quality and quantity, its impact was not designated only to local markets but also to foreign markets. ${ }^{369}$ Excluding protection of pharmaceutical products from the Indian Patents Act intensified the growth of the generic Indian pharmaceutical industry and elevated it to become one of the leading generics producer and exporter around the world. $^{370}$

People from other developing countries and even from developed countries have enjoyed low cost quality drugs. ${ }^{371}$ India has become a key exporter of drugs and earned substantial reputation in the international market as a strong drugs' manufacturer and exporter. ${ }^{372}$ The contribution patent's abolishment from pharmaceutical products in the Indian Act was not concluded by the reduction of drugs' pricing. The second most important result was the opportunity generic production gave for the local industry to advance its innovative capacity. ${ }^{373}$ Although the numbers were small at the beginning, by the end of 1980s, Indian firms were capable of producing new chemical compound based drugs ${ }^{374}$ and by the end of the 1990s, several firms achieved innovative capacity. ${ }^{375}$ Through the process of learning from published data, ${ }^{376}$ trials and errors, experiments and self teaching, ${ }^{377}$ Indian scientists advanced their skills which resulted in more quality products in the market and not only quantity. ${ }^{378}$

\footnotetext{
${ }^{368}$ Ibid.

${ }^{369}$ See generally Chaturvedi, Chataway and Weild, above n 10, 572.

${ }^{370}$ See generally Garai, above n 191. See also Chataway, Tait and Wield, above n 107, 698.

${ }^{371}$ See David K Tomar "A Look into the WTO Pharmaceutical Patent Dispute Between the United States and India” (1999) 17 Wis Int'l LJ 579,592. See also Mueller, above n 311, 515.

${ }^{372}$ See generally Tomar, above n 371, 592. See also Mueller, above n 311, 515.

${ }^{373}$ See generally Kale, Little, above n 253, 599.

${ }^{374}$ Ibid, 598. See also Chaturvedi, Chataway and Wield, above n 10, 572.

${ }^{375}$ See generally Chataway, Kale and Weild, above n 166, 559- 560. See also Kale, Little, above n 253, 589. See also Adelman, Baldia, above n 313, 525.

${ }^{376}$ See Clark A D Wilson "The TRIPS Agreement: Is It Beneficial to the Developing World, or Simply a Tool Used to Protect Pharmaceutical Profits for Developed World Manufactures" (2005) 10 J Tech L \& Pol'y 243, 255.

${ }^{377}$ See Kale, Little, above n 253, 596 - 597.

${ }^{378}$ Ibid, 597.
} 
However, the progress achieved in the innovative level of the industry was not enough. The innovative activity was considerably small and as India changed, the world has changed as well and the new dawn of intentional intellectual property regime was about to start. India needed to be a part of the international pharmaceutical industry arena, this time, not only through generics. India was facing the necessity of altering its non patent protection on pharmaceutical products in order to access the Western advanced technologies, in order to continue to advance its skills and innovative capacity. This was a leading way for India's pharmaceutical industry to be synchronised with the world.

Additionally, although generics production has changed the local feasibility to access drugs, it did not change the landscape of the local healthcare status as needed. ${ }^{379}$ Still the majority firms in the pharmaceutical industry practiced generics production, neglecting the production of new chemical entity drugs. ${ }^{380}$ Consequently, Indian scientists started either to leave the country or stayed outside of India after completing their foreign training. ${ }^{381}$ There was just no reason for them to stay in India for it did not offer them a protection of their potential inventions. ${ }^{382}$

It is needless to mention that with the changing international intellectual property protection, and the Western extreme reluctance of the growing Indian generic activity, generic production was not to assist in establishing a stronger innovative industry or to improve India's economic prospects for the chance it would be excluded from the international community quid pro quo relationship. As much as the Indian generic industry relied on Western innovation, the West was not about to continue and lose out from the price reducing generic competition. Threatened by generics, pharmaceutical firms were constantly losing their investment in the costly research and development. ${ }^{383}$

Something had to change. Wishing to be a part of the international economic outline, India had to become an equal party to the international market with equal

\footnotetext{
${ }^{379}$ See Palit, Bhattacharya, above n 215, 84.

${ }^{380}$ See Mueller, above n 313, 515.

${ }^{381}$ Ibid.

${ }^{382}$ Ibid. See also PhRMA "PhRMA Welcomes Passage of Patent Bill in India" (23 March 2005) Press Release.

${ }^{383}$ See generally Gadbaw, Richards above n 71, 13 .
} 
standards of intellectual property rights frame. ${ }^{384}$ As stated earlier, legitimising generic production of pharmaceutical product in India put pharmaceutical multinationals in an economic swamp. The fact that generic drugs were offered at a lower cost and created an extensive competition with the brand name drug, the inventor had to reduce the drug's price for it to be still an active player in the marketplace. ${ }^{385}$ Not only could these firms not compete with the local generic cheaper versions of drugs, ${ }^{386}$ they also suffered from an extensive generic grasp in their home markets which did offer patent protection for their innovations. ${ }^{387}$ It was clear that the breached intellectual property right regime ought to be whole again.

Furthermore with the price control mechanism reducing the cost of drugs in the Indian marketplace, Western firms were pushed to reduce their drugs prices which only made it more difficult for them to get returns for their costly investment. ${ }^{388}$ Consequently, foreign pharmaceutical firms which invested in the Indian markets and introduced new drugs to the marketplace had to withdraw for their presence diminished their chance to recoup their costly investment. ${ }^{389}$

Although the local industry was finally free from foreign powerful control over the local markets, it was left with its own limited technological and scientific knowledge. The advanced multinational pharmaceutical firms were not sharing knowledge with the local industry anymore, or introducing new research and development advanced technologies to be copied. ${ }^{390}$ It was soon clear that continuing with only generic production, was not in the best interest of India to access foreign

\footnotetext{
${ }^{384}$ See Chaturvedi, Chataway and Wield, above n 10, 572.

${ }^{385}$ See The Congress of the United States, above n 216.

${ }^{386}$ See Gadbaw, Richards above n 71, 90. See also Friedrich - Karl Beier, Gerhard Schricker (eds) GATT or WIPO? New Ways in the International Protection of Intellectual Property (v 11, Vch Pub, Germany, 1989) 357, 361363.

${ }^{387}$ See Duncan Matthews Globalising Intellectual Property Rights The TRIPS Agreement (Rouledge, London, 2002)12.

${ }^{388}$ See generally Adelman, Baldia, above n 313, 527.

${ }^{389}$ See generally Gadbaw, above n 71, 132-133.

${ }^{390}$ Shanker A Singham "Competition Policy and the Stimulation of Innovation: TRIPS and the Interface between Competition and Patent Protection in the Pharmaceutical Industry" (2000) 26 Brook J Int'l L 363, 374.
} 
advance technologies. Becoming an equal enforcer of intellectual property rights was. $^{391}$

India understood the importance of technology transfer in its economic rise as in 1991 it fully opened its market to foreign direct investment. ${ }^{392}$ Due to the new policy, foreign firms interests were treated the same as local's and as a result, India has experienced increasing income and improved quality of life through Western new technologies. ${ }^{393}$ This new step the Indian Government took was considered the changing point of India's economic growth, poverty decline and the strengthening of its standee on the international platform. ${ }^{394}$ The new liberalisation of the early 1990s gave the local industry the opportunity to engage with Western technological advances. ${ }^{395}$ The chance to become a part of the international economy was a chance India was not about to dismiss. Opened up to foreign firms and with it the demand for improved manufacturing, the local pharmaceutical industry started to engage with innovative development. ${ }^{396}$ It could than enjoy from Western support and collaboration.

Given the reform the Indian innovative capacity was going through by embracing innovative skills, the next natural step which was about to deepen this opportunity was of course joining the World Trade Organisation and signing the TRIPS Agreement. India started to feel the need to move towards an international practice of intellectual property rights. ${ }^{397}$ This understanding was taking place even in least developed countries. ${ }^{398}$ After the failed trials to adjust the Paris Convention to fit the interests of both the developed and the developing world interests, ${ }^{399}$ the constant cry

\footnotetext{
${ }^{391}$ See Rajnish Kumar Rai "Effect of the TRIPS-Mandated Intellectual Property Rights on Foreign Direct Investment in Developing Countries: A Case Study of the Indian Pharmaceutical Industry" (2009) 11(5) Journal of World Intellectual Property 404, 406.

${ }^{392}$ See Baker, above n 121, 393. See also Chaturvedi, Chataway and Wield, above n 10, 572.

393 See Baker, above n 121, 395.

${ }^{394}$ Ibid.

${ }^{395}$ See generally Chaturvedi, Chataway and Weild, above n 10, 572.

${ }^{396}$ Ibid.

${ }^{397}$ See generally Sell, above n 350, 410. Hans Peter Kunz-Hallstein "The United States Proposal for a GATT Agreement on Intellectual Property and the Paris Convention for the Protection of Industrial Property (1989) 22 Vand J Transnat'l L 265, 277. See also Dettmann, above n 66, 355. ${ }^{398}$ Ibid.

${ }^{399}$ See generally Kunz-Hallstein, above n 397, 266. According to the author it was apparent that the key obstacle to the negotiation was the non-exclusive right the generic firm could have under the authoration of compulsory license which the developed world wished to alter to exclusive. See
} 
from pharmaceutical industries in the developed world pushed for an international honouring of patent protection and in a large scale. ${ }^{400}$

Prior to examining the new regime through analysing the TRIPS Agreement patent enforcement, it is worthwhile reviewing in more detail the damaging effects the non-patent regime in the developing world imposed on pharmaceutical multinationals, which ultimately forced the constitution of the TRIPS Agreement. This is the only way to demonstrate why the enforcement of patent in Western countries was not enough, although the prospect of benefiting from the developing world's markets was not high.

Following this review, the chapter next examines the TRIPS Agreement's different provisions, to present the new patent regime developing countries had to enforce. While analysing the provisions in the TRIPS Agreement, the next section does not dismiss the flexible measures the Agreement offered to weaker economies as in the developing and least developed countries in time of a need to access patented high cost drugs. This aspect is of great importance to show that the international intellectual property community did not dismiss the difficulty the developing world faced concerning accessing patented drugs and was far from ignoring the global healthcare high value. No, the TRIPS Agreement did not offer an optimal settlement for developing and least developed countries but it did offer some relief and most of all it offered India a chance to better its healthcare status through more efficient ways than generics.

\section{B. Generics Fall and Innovation Rise}

With the continuing increase in the costs of pharmaceutical innovation, the return of expenses was essential for the continuance of the innovative activity in the pharmaceutical industry. ${ }^{401}$ However, the prospect was not to be fulfilled because of the constant expanding generic competition directed by the developing world. ${ }^{402}$ Led

generally Monique L Cordray “GATT V WIPO“(1994) 76 Journal of Patent and Trademark Office Society $121,139$.

${ }^{400}$ See generally Weissman, above n 307, 1068, 1075-1080. See also Karl - Beier, Schricker, above n 386,361 .

401 See Dettmann, above n 66, 350.

${ }^{402}$ See generally Emmert, above n 352, 1337. See also The Congress of the United States, above n 216. 
by the goal to strengthen the domestic pharmaceutical markets through imitation, reduce the inflation existing in the pharmaceutical industry due to high costs of the patented drugs, as well as creating availability to life saving drugs, India, Mexico, Argentina and Singapore as well as other developing countries conducted high level of piracy generic sales, ${ }^{403}$ claiming intellectual property for a common heritage. ${ }^{404}$

For a country like the United States, this perspective was not encouraging. The chances to preserve dominancy in the international arena were only possible with national and international enforcement of patent protection. ${ }^{405}$ In other words, its market superiority was not saved with high generic activity directed from the developing world.

According to the Global Competition - The New Reality Report, the inadequate international patent enforcement prior to the TRIPS Agreement settlement, almost paralysed the innovative activity in the United States. ${ }^{406}$ This result could have been dangerous for it would have put a stop to drugs' innovation. According to the United States International Trade Commission, in 1986 the United States lost between US\$43 to US\$61 billion in the pharmaceutical industry alone. ${ }^{407}$ Although many countries signed the Paris Convention for the Protection of Industrial Property (Paris Convention), they kept breaching its provisions and due to an insufficient enforcement, the developed world cry to stop generics production during patent enforcement was not answered.

Argentina for example, an upper middle developing country today, and a signatory member to the Paris Convention since $1967,{ }^{408}$ denied patent protection for

\footnotetext{
${ }^{403}$ See Gadbaw, above n 71, 13.

${ }^{404}$ See Sell, above n 350, 410. Developing countries also claimed that the pharmaceutical industry would not propsepctively to loss from the generic firms' piracy for the major profit is within the Western richer markets. In this regards see Matthews, above n 387, 8.

${ }^{405}$ See President's Commission on Industrial Competitveneess Global competition: The New Reality: Preserving America's Industrial Competiveness A Special Report on The Protection of Intellectual Property Rights (v II, President's Commission on Industrial Competitiveness, Washington DC, 1985) 304-306.

${ }^{406}$ Ibid, 306-307.

${ }^{407}$ See Cordray above n 399, 139. See also United States Intenrational Trade Commission Foreign Protection of Intellectual Property Rights and the Effects on the US Industry and Trade (USITC, Wahington DC, 1988).

${ }^{408}$ See Paris Convention Contracting Parties www.wipo.int/treaties/en/ip/paris/ (accessed 10 December 2008).
} 
pharmaceutical products prior to its joining to the TRIPS Agreement. ${ }^{409}$ Although it offered protection for pharmaceutical processes for 15 years, the Government could easily provoke the patentee's exclusive rights over the invention if after two years, the patented drug was not been worked (sold for example) in the local marketplace. ${ }^{410}$ This enactment contradicted Argentina's obligation under the provisions of the Paris Convention which allowed breaching the patentee's rights only to prevent an abusive exploitation of the patented product by the patentee. ${ }^{411}$

Moreover, although the Paris Convention had tried to answer the need for intellectual property rights enforcement, considering both the upper economies and the lower, it was irrelevant. The lack of patentability criteria, the lack of setting a minimum term for patent protection, the lack of exclusivity rights for the patentee, the inevitable compulsory licence with no compensation, ${ }^{412}$ and the toothless dispute settlement the convention has offered, ${ }^{413}$ gave the developing countries the most efficient tool to create a loose patent regime, and conduct "legal pirating" of the developed world's expensive pharmaceutical patented products. As India's intense generic activity, also the loosened Argentine patent protection ${ }^{414}$ contributed to foreign pharmaceutical companies losses in approximately US\$250 million per year. ${ }^{415}$ It was clear that without a common international patent protection for pharmaceutical products' platform, substantial losses to the innovative pharmaceutical industries in the developed world were to increase rapidly.

As can be expected, facing growing losses in the developing world and due its generic copying practice, pharmaceutical firms started to leave the developing world's markets. ${ }^{416}$ In order to prevent the risk of using their products and technologies without any proper remuneration, foreign firms were left with no other choice. ${ }^{417}$ Note

\footnotetext{
${ }^{409}$ See Mossinghoff, above n 354, 314. See also Gadbaw, above n 71, 125-128.

${ }^{410}$ Ibid.

${ }^{411}$ See Paris Convention, above n 349, art 5A 1-4.

${ }^{412}$ See Sell, above n 350, 409-410.

${ }^{413}$ See Kunz-Hallstein, above n 397, 278, 281-282. For further discussion on the inadequate performance of the Paris Convention see Carlos Alberto Primo Braga "The Economics of Intellectual Property Rights and the GATT: A View from the South" (1989) 22 Vand J Transnat'1 L 243, 252. See also Cordray, above n 399, 132-133.

${ }^{414}$ See generally Gadbaw, above n 71, 113.

${ }^{415}$ Ibid, 125.

${ }^{416}$ Ibid, 132.

${ }^{417}$ Ibid, 132.
} 
that the risk was not directed only by India and Argentina but from other developing countries as Mexico, Brazil, and Africa which literally drove pharmaceutical multinationals away. ${ }^{418}$

Japan and Europe which were also the losing party to the generic vast activity ${ }^{419}$ joined the United States and rigorously fought for an international, one levelled intellectual property rights enforcement in any field of technology, especially in the pharmaceuticals. ${ }^{420}$ Although the developing world population could not be a good consumer for the patented drugs, the generic copying penetration to Western markets was too high and demanded a deep reform in developing countries patent enforcement regime. $^{421}$

At first there was constant pressure from the developed world to revise the Paris Convention. ${ }^{422}$ After these attempts failed, ${ }^{423}$ the United States endorsed strict bilateral sanctions on countries which did not comply with wide intellectual property rights enforcement. ${ }^{424}$ These countries were confiscated from any trade relationship, when at the same time it was one of the prime factors to the survival and growth of these countries' economies, as today. Trading with the advanced developed world, accessing new technologies was a key factor in the developing world's market growth. Consequently Taiwan, Korea and Singapore (developing countries at that time) were soon to alter their patent regime and offered a wide scope of protection in the pharmaceutical technology field. ${ }^{425}$

In addition to the pressure which was directed to the developing world, the United States was still aware of the importance of the generic industry apart from the pharmaceutical industry's innovative activity. Therefore, the United States Congress

\footnotetext{
${ }^{418}$ Ibid, 90. See also Beier, Schricker, above n 386, 357, 363.

${ }^{419}$ See generally Beier, Schricker, above n 386, 361. See also Sell, above n 350, 411,414. See also Dettmann, above n 66, 351. See also President's Commission on Industrial Competitveneess, above $\mathrm{n}$ 405, 304.

${ }^{420}$ See Matthews, above n 387, 12. See also Randy L Cambell "Global Patent Law Harmonization: Benefits and Implementation” (2003) 13 Ind Int'l \& Comp L Rev 605, 606. See also Kevin Cuenot "Perilous Potholes in the Path toward Patent Law Harmonization" (1997) 11 JL \& Pub Pol'y 101, 101.

${ }^{421}$ See Matthews, above n 387, 12.

${ }^{422}$ See generally Weissman, above n 307, 1068, 1075-1080.

${ }^{423}$ See Kunz-Hallstein, above n 397, 266. See also Cordray, above n 399, 139.

${ }^{424}$ See generally Sell, above n 350, 414, 417. See also Matthews, above n 387, 25-26.

${ }^{425}$ See generally Mossinghoff, above n 354, 316-318.
} 
passed the 1984 Drug Price Competition and Patent Term Restoration Act $^{426}$ to find a proper balance between the two ends. While simplifying the process of generic drugs application to the Food and Drug Administration in the United States, the Act introduced abbreviated approval processes for generics copies and their marketing in the country.

It also allowed generic manufacturers to test the original patented drug before the end of the patent term, all in an attempt to increase generic drugs availability in the market as soon as the patent protection term over the original drug was over. In parallel and in a try to continue to motivate the pharmaceutical industry research and development activity, the Act approved patent term extension. Given that the count of the patent protection term begins prior to clinical trials, until the food and drug administration approves the marketing of a drug, the pharmaceutical firm is not left with many years of market exclusivity to return its expenditures. Addressing the two aspects, the United States Congress tried to assure better marketing platform for generics as well as assuring a safe platform for innovation, free from the threat of copying as long as the patent protection was in order. ${ }^{427}$ Nevertheless, the prospect to enter the Western markets only increased Indian generic exports to the United States $^{428}$ and the process of copying drugs and selling them elsewhere was still in process.

The developed world could not only relax the generic competition with local means. There was a need for international comprehensive reform. India was not easily persuaded. ${ }^{429}$ India still feared the impact patenting pharmaceutical products would have on drug affordability by its population. India did not want to risk the chance it had to offer low cost drugs to its population. Excluding patent protection was indeed the easiest and the cheapest way to access the advanced pharmaceutical technological process, offer low cost drugs and at the same time benefit from expanding the sales of generics to foreign richer countries. However it was not the ideal solution to all parties. As much as the Indian industry gained from high sales of generics in Western

\footnotetext{
${ }^{426}$ See Drug Price Competition and Patent Term Restoration Act of 1984 (United States) Pub L No 98417, 98 Stat 1585.

${ }^{427}$ See generally The Congress of the United States, above n 216.

${ }^{428}$ See generally Chataway, Tait and Wield, above n 107, 703-704.

429 John F Duffy "Harmony and Diversity in Global Patent Law" (2002) 17 BTLJ 685, 695.
} 
markets, the developed countries industries were losing, considerably. If India wanted to be a part of the international economic community, it had to synchronise with it completely.

Nevertheless there was still a need to find the proper balance, one which would protect the innovators interest of exclusivity and at the same time offer equal chances for all to access needed products as drugs. ${ }^{430}$ The TRIPS Agreement, concluded in 1994, tried to achieve that balance. ${ }^{431}$ Although both the developed and the developing world were involved in its drafting, one thing was not flexible and that was the full scope of patent protection for products and processes in every technology field. On the other hand, the agreement did include several exceptions to the exclusive right of the patentee in a try to answer poor economic countries population to access patented drugs with affordable prices. However the TRIPS Agreement did not oblige patent holders to assist or even use their sources to help poor economies to access drugs during the difficult timing of implementing new intellectual property rights regime. ${ }^{432}$ In this respect, one can say that the balance the TRIPS Agreement tried to achieve was still unequal. ${ }^{433}$

Although India prominently fought against an international enforcement of patent on pharmaceuticals, it finally understood that generics as much as their production contributed to the poor for it enabled low cost drugs in the marketplace, it did not better the country's health care or India's position in the eyes of the international community. Ultimately the reluctant India, alongside with other developing countries, joined the World Trade Organisation, signed the TRIPS Agreement ${ }^{434}$ and in 1998 India also joined to the Paris Convention as a signatory country ${ }^{435}$ and to the Patent Cooperation Treaty. ${ }^{436}$ The new era of developing countries enforcement of intellectual property rights was about to begin.

\footnotetext{
${ }^{430}$ Ibid.

${ }^{431}$ Ibid.

${ }^{432}$ See Brittany Whobrey "International Patent Law and Public Health: Analyzing TRIPS' Effect on Access to Pharmaceuticals in Developing Countries" (2006-2007) 45 Brandeis LJ 623, 638. ${ }^{433}$ Ibid.

${ }^{434}$ See Dettmann, above n 66, 389-370. See also Matthews, sbove n 387, 33.

${ }^{435}$ See Paris Notification No188 Paris Convention for the Protection of Industrial Property Accession by the Republic of India www.wipo.int/edocs/notdocs/paris/treaty_paris_188 (accessed 4 April 2009).

${ }^{436}$ See Patent Cooperation Treaty Notification No 129 Accession by the Republic of India www.wipo.int/treaties (accessed 4 April 2009).
} 
Meanwhile a vast debate began concerning the implications signing the TRIPS Agreement would have on the fast evolving Indian pharmaceutical industry. ${ }^{437}$ Many feared a direct increase of drugs' pricing. ${ }^{438}$ Reviewing the pharmaceutical industry of today stresses these concerns as ungrounded. As Bruce stated, in not so many years from today, a large volume of patented drugs would be off patent protection and the difficulty in allocating new chemical entity drugs, would keep high volume of generics production and offer low cost drugs to the local population.

The Uruguay round Multilateral Trade negotiation (1986-1994) opened with the failure to revise the Paris Convention resulting in the institution of the World Trade Organization which took the responsibility of dealing with trade issues and of course with the constitution of the TRIPS Agreement. ${ }^{439}$ The World Trade Organization declared its objectives to help trade flow "smoothly, freely fairly and predictably" and enforce the TRIPS Agreement. ${ }^{440}$ One of the important principles treated in the agreement is the contribution of intellectual property to technical innovation and the exchange of technology. ${ }^{441}$

According to the TRIPS Agreement "patents shall be available for any inventions whether products or processes in all fields of technology, provided that they are new, involve with an inventive step and are capable of industrial application". ${ }^{442}$ The patent term was also adjusted to 20 years ${ }^{443}$ which for some countries decreased the term of protection as the United States which enjoyed the extension under the 1984 Drug Price Competition and Patent Term Restoration Act. Developed countries were given one year to ensure that their laws conformed to the TRIPS Agreement. ${ }^{444}$ Given that the process participated to be more complex in developing countries which enforced weak or non intellectual property rights, these countries were given five years until

\footnotetext{
${ }^{437}$ Chaturvedi, Chataway and Wield, above n 10, 565.

${ }^{438}$ See generally Dean, above n 82, 732 .

${ }^{439}$ See The World Trade Organisation www.wto.org (accessed 20 November 2008).

${ }^{440}$ Ibid.

${ }^{441}$ Ibid.

${ }^{442}$ See TRIPS Agreement, above n 1, art 27(1). According to the Article "Subject to the provisions of paragraphs 2 and 3, patents shall be available for any inventions, whether products or processes, in all fields of technology, provided that they are new, involve an inventive step and are capable of industrial application...patents shall be available and patent rights enjoyable without discrimination as to the place of invention, the field of technology and whether products are imported or locally produced".

443 Ibid, art 33.

${ }^{444}$ Ibid, art 65(1).
} 
2000 to complete the implementation of the agreement's provisions. ${ }^{445}$ Developing countries as India which did not provide patent protection in the pharmaceutical technology field in 1995, were given an additional five years of preparation before fully enforcing patent protection of pharmaceutical process and products, until the year $2005 .^{446}$

During the years 1995-2005, India reformed its Patent Act 1970 and slowly adjusted its health policies to suit the new worldwide patent regime. During the transition period the Indian pharmaceutical industry was not about to reverse its progression. According to the TRIPS Agreement all drugs which were invented prior the year 1995, were eligible for generic copying. ${ }^{447}$ This was a term which was not negotiable. Respectively all inventions which were introduced during the transition period in the fields of pharmaceuticals, agricultural or chemical products were to put in what is called a mailbox. ${ }^{448}$ In 2005 the Indian Patent Controller was to open the application and review them. ${ }^{449}$ In order to protect these applications from generic copying, the applicants were given exclusive marketing rights for a period of five years or until the product was granted or denied patent protection, whichever was sooner. $^{450}$

The continuance of the generic industry during the transition period allowed the Indian industry to constantly grow. Local firms in India maintained more than 70 per cent share in the marketplace, while multinationals share decreased to less than 30 per cent by the year 2005. Even exporting was constantly increasing. If in 1996 exports were capitalised in US\$700 million, by the year 2006, figures increased to US\$3 billion. ${ }^{451}$ The research and development investment were also increasing given the new prospect of collaborating with the Western pharmaceutical industry from 2 per cent to $7-8$ per cent in $2004-2005 .^{452}$

\footnotetext{
${ }^{445}$ Ibid, art 65(2).

${ }^{446}$ Ibid, art 65(4).

${ }^{447}$ See Sherwood, above n 117, 498-499. See also Dean, above n 82, 730.

${ }^{448}$ See TRIPS Agreement, above n 1, art 70(8). During India's transition period 6,600 applications were submitted to the mailbox in the pharmaceutical technology field. See Mueller, above n 311, 523.

${ }^{449}$ See TRIPS Agreement, above n 1, art 70(8).

${ }^{450}$ Ibid, art 70(9).

${ }^{451}$ Chaturvedi, Chataway and Wield, above n 10, 575.

${ }^{452}$ Ibid.
} 
In practice, member countries were allowed to implement the different provisions in the agreement as they saw fit. ${ }^{453}$ The agreement did not specify the context of the terms ${ }^{454}$ and thus member countries were free to fill the gaps to their discretion, ${ }^{455}$ trying to answer their interests of health, nutrition and other socio-economic needs. ${ }^{456}$ The only restriction was that all were to fit their interpretation to the obligatory elements in the agreement. ${ }^{457}$ As India excluded incremental innovation from patent scope which is the main source of innovation in the pharmaceutical industry, some critic its conduct as breaching its obligation not to discriminate any field of technology from patent protection enforcement. ${ }^{458}$

As mentioned earlier, the TRIPS Agreement was constructed while considering the need of poorer countries to access patented drugs and maintain their public healthcare. According to the given flexibilities, countries could revoke the rights from the patentees when they were misusing the patent in a way which would hurt fluent international technology transfer. ${ }^{459}$ Countries were also allowed to exclude patent protection from inventions which were considered harmful to humans, plants, animals, life or to the environment. ${ }^{460}$ Surgical or therapeutic methods for humans or animals were eligible inventions for exclusion as well. ${ }^{461}$ If the patentee's exclusive rights were in conflict with the utilisation of the patented product and were used in an arbitrary way, a member country was also allowed to revoke the patent. ${ }^{462}$ There was even one option to revoke the exclusive rights of the patentee if one applied to use the patented product for experimental purposes. ${ }^{463}$ That would enable generic firms to

\footnotetext{
${ }^{453}$ See TRIPS Agreement, above n 1, art 1.

${ }^{454}$ See Chaisse, Guennif, above n 360, 8.

${ }^{455}$ Ibid. See also TRIPS Agreement, above n 1, art 7, 8.

${ }^{456}$ See TRIPS Agreement, above n 1, art 7, 8.

${ }^{457}$ Ibid, art 8.

${ }^{458}$ See Rajnish Kumar Rai "Patentable Subject Matter Requirements: An Evaluation of Proposed Exclusions to India's Patent Law in Light of India's Obligation under the TRIPS Agreement and Options for India" (2008) 8 Chi-Kent J Intell Prop 41, 77.

${ }^{459}$ See TRIPS Agreement, above n 1, art 8(2).

${ }^{460}$ Ibid, art 27(2).

${ }^{461}$ Ibid, art 27(3).

462 Ibid, art 30.

${ }^{463}$ Ibid. This exception is commonly known as the Bollar exception. It was named after the the case Roche Products Inc v Bolar Pharm Co Inc, above n 104. It was held that the United States laws did not allow 'experimental use'of patent and Bolar could not develop and submit a generic product for regulatory approval before the expiry of Roche's patent protection term. The Drug Price Competition and Patent Term Restoration Act of 1984, The Drug Price Competition and Patent Term Restoration Act of 1984 legislation introduced such an exemption favouring generic companies in response to the
} 
prepare the generic version of the patented drug to be marketed as soon as the patent protection term ends.

The TRIPS Agreement also enforced various measures to promise a platform of more affordable drugs. One was compulsory licensing. ${ }^{464}$ Under this mechanism the Indian Government, for example, can order to breach the patentee's rights on the invented drug, without having the patentee's approval, if cheaper distribution is needed in times of emergencies and in situations of anticompetitive practices. Often ordering compulsory lessening is accompanied by an economic value of the license remuneration. ${ }^{465}$

In times of emergencies as mentioned above, having the patentee's agreement is not necessary, however, generally, there is an obligation to set up the use of the patented drug with "reasonable terms and conditions". Most of the times, reaching a common ground is not practical. ${ }^{466}$ Moreover, the use of the drug is predominantly permitted to the domestic market. Nevertheless if there are countries without any manufacturing capacity, compulsory licensing can be authorised to a third country, to generically produce the drug and distribute it to the first countries. ${ }^{467}$ It seems that the purpose of setting the order of compulsory licensing can be concluded as a try to strike a balance between accessibility to drugs and at the same time still providing an incentive for continuing research and development in the pharmaceutical industry. ${ }^{468}$

Another class of flexibilities is formed through parallel importation. ${ }^{469}$ In this process for example, India and China patent the same drug owned by the pharmaceutical firm Pfizer, however, given that the drug is sold at a high price in India, the country imports the drug from China, and sells it at a lower cost. Thus, the

aforementioned ruling. See The Drug Price Competition and Patent Term Restoration Act of 1984, above $\mathrm{n} 426$.

${ }^{464}$ See TRIPS Agreement, above n 1, art 31.

${ }^{465}$ Ibid. See generally Sara M Ford "Compulsory Licensing Provisions under the TRIPS Agreement:

Balancing Pills and Patents" (2000) 15 Am U Int'l L Rev 941, 945.

${ }^{466}$ See Charlest T Collins-Chase "The Case Against TRIPS-Plus Protection in Developing Countries Facing AIDS Epidemics" (2007-2008) 29 U Pa J Int'l L 763, 773.

${ }^{467}$ See TRIPS Agreement, above n 1, art 31.

${ }^{468}$ See Chaisse, Guennif, above n 360, 13.

${ }^{469}$ See TRIPS Agreement, above n 1, art 6. 
cost of the same drug is being equalised among all countries ${ }^{470}$ and at the same time not hurting the patentee's right to compensation as fulfilled by the exporting country, in this example, China. ${ }^{471}$

Trusting patent to be the ultimate mechanism to induce innovation, reduce imitation, risky competition and serve its trading interest, the United States led developed countries to embrace stricter bilateral free trade agreements of intellectual property, which known as the TRIPS-Plus Agreements. ${ }^{472}$ Under this set of agreements patent protection term can be extended beyond the 20 years protection, some restrict the permissible terms of compulsory licensing and give the patentee with the right to stop parallel importation. ${ }^{473}$

Under the TRIPS-Plus frame, developed countries enforce 130 bilateral and regional free trade agreements. In recent years, the United States has formed TRIPSPlus Agreements with Jordan, Chile, Singapore, Australia, Morocco and Central America. ${ }^{474}$ The same takes place in Europe which recently completed more than 30 agreements in the Middle East and North Africa. ${ }^{475}$ Constructing the TRIPS - Plus Agreements was not to say that the TRIPS Agreement is too weak. On the contrary, many criticised the TRIPS Agreement as being too strong and a result of grave bilateral sanctions directed to the developing world to convince them to sign the agreement. ${ }^{476}$ Understandably, with the limited capital, technologies and innovative skills, the advice for the developing world is to exclude the TRIPS-Plus mechanism and stay determent to the TRIPS Agreement flexibilities. ${ }^{477}$

As Collins-Chase stated the benefits are too little in comparison to the cost, especially in the pharmaceutical technology field. The cost of the diseases is too much of a burden on a developing countries' economy. ${ }^{478}$ Respectively Collins-Chase supported Thailand moving away from bilateral free trade agreements as the TRIPS-

\footnotetext{
${ }^{470}$ See Collins-Chase, above $\mathrm{n} 466,773$.

${ }^{471}$ Ibid.

${ }^{472}$ See generally Harrelson, above n 319, 779.

${ }^{473}$ See generally Collins-Chase, above n 466, 780 .

${ }^{474}$ Ibid, 779.

${ }^{475}$ Ibid, 780 .

476 Ibid, 779.

${ }^{477}$ Ibid, 763 .

${ }^{478}$ Ibid, 801.
} 
Plus. ${ }^{479}$ In countries with high rates of HIV/AIDS patients, the option to access drugs has to be promised by using the flexibilities in the TRIPS Agreement. Until developing substantial research and development platform to truly benefit from higher standard of intellectual property rights enforcement, developing countries should stay loyal as much as possible to its population health care interests. ${ }^{480}$ Nevertheless, the author did not criticise developing countries' adoption of the TRIPS Agreement and encouraged a wider use of the different flexibilities as compulsory licensing to enable a wider access to drugs at low cost. ${ }^{481}$

To the pressure to enforce even stronger standard of patentability applied by the United States and European countries, the developing world responded with pressuring for forming better international healthcare elements. The resulted Declaration on the TRIPS Agreement and Public Health signed in Doha (Doha Declaration) ${ }^{482}$ tried to answer the latter request. As was declared the "TRIPS Agreement does not and should not prevent members from taking measures to protect public health". ${ }^{483}$ Although the concept was originally designated to cope with the AIDS epidemic and tropical diseases such as malaria, ${ }^{484}$ it promoted protection of public health in general and obliged reading the TRIPS Agreement in accordance to the needs of poorer economic countries to access needed patented drugs. ${ }^{485}$

Accordingly, the Doha Declaration supplied developing countries with an approval to reaffirm the TRIPS Agreement's flexibilities to the fullest. ${ }^{486}$ That included the right countries had to set the grounds which legitimise compulsory licensing by defining their own "national emergency" or "extreme urgency". ${ }^{487}$ India took this opportunity to the fullest and widened the various conditions of its local compulsory licensing policy to offer its population with affordable drugs at any time. $^{488}$

\footnotetext{
${ }^{479}$ Ibid, 801.

${ }^{480}$ Ibid, 802.

${ }^{481}$ Ibid, 802.

${ }^{482}$ See Doha Declaration, above n 16.

${ }^{483}$ Ibid, art 4 emphasis added.

${ }^{484}$ Ibid, art 1.

${ }^{485}$ Ibid, art 4, 5.

${ }^{486}$ Ibid, art 4

${ }^{487}$ Ibid, art 5(b).

${ }^{488}$ See The Patents (Amendment) Act 2002 (India), ss 82-94.
} 
In a later decision of the General Council of the World Trade Organisation, which has the power to vary the original TRIPS Agreement, ${ }^{489}$ the problem of drugs accessibility in countries with no manufacturing capabilities was answered as well. ${ }^{490}$ According to the aforementioned decision, countries which do have manufacturing capabilities can use the compulsory licensing route to enable them to produce a generic version of the patented drug in order to distribute it to a country which lacks manufacturing capabilities. ${ }^{491}$

With three different amendments, India implemented the provisions of the TRIPS Agreement to the fullest. It implemented the extension of the patent term and the implementation of the two leading international intellectual property treaties authorisation (the Paris Convention and the Patent Cooperation Treaty) to its Patent Act. ${ }^{492}$ It amended its definition of "invention" ${ }^{493}$ and "inventive step" ${ }^{494}$ to define a patentable subject matter in the TRIPS Agreement. ${ }^{495}$ India also revised its compulsory licensing framework ${ }^{496}$ and removed patent protection restrictions from pharmaceutical products. ${ }^{497}$

Moreover, India has used one more key to ease its public healthcare status through the pre - grant and post-grant opposition procedure. ${ }^{498}$ In practice, India is the only country among other patent granting countries which offers both pre and post grant opposition platform for patent authorisation. ${ }^{499}$ Under the pre-grant opposition any person has the right to oppose at any time the authorisation of patent protection of an

\footnotetext{
${ }^{489}$ See generally The WTO General Council www.wto.org (accessed 18 November 2009).

${ }^{490}$ See WTO General Council Implementation of Paragraph 6 of the Doha Declaration on the TRIPS Agreement and Public Health (WT/L/540 and Corr 1, Geneva, 2003).

${ }^{491}$ Ibid. Fearing from the developed countries reaction, developing countries were reluctant to use this marketing freedom. Some countries declared they will not use it. See Understanding the WTO: The Agreements: Intellectual Property: Protection and Enforcement www.wto.org (accessed 29 March 2009). Some declared that they will use the right only in emergencies. See WTO Fact Sheet: TRIPS and Pharmaceutical Patents: Obligation and Expectations www.wto.org (accessed 29 March 2009). This revision which compromised pharmaceutical innovators market superiority through generic production raised vast criticism from the pharmaceutical industry. See Ford, above n 465, 966.

${ }^{492}$ See The Patents (Amendment) Act 2002 (India), ss 3(b), 3(e), 3(k), 7. See also Patent Cooperation Treaty (19 June 1970) 1160 UNTS 231.

${ }^{493}$ See The Patents (Amendment) Act 2002 (India), s 2(g)(1).

${ }^{494}$ Ibid, s 2 (f)(ja).

${ }^{495}$ See TRIPS Agreement, above n 1, art 27.

${ }^{496}$ See The Patents (Amendment) Act 2002 (India), ss 82-94.

${ }^{497}$ See The Patents (Amendment) Act 2005 (India), s 5.

${ }^{498}$ Ibid, s 25.

${ }^{499}$ See Dhar, Gopakumar, above n 179.
} 
invention, which entitles that person with a hearing conducted by the Patent Controller. In the United States for example there is not a pre-grant opposition, especially not one which would allow "any person" to oppose to the authorisation of patent. ${ }^{500} \mathrm{By}$ allowing the participation of any person in the opposition process, India's Parliament has invited civil organisations to become a party to the Patent Controller decision in any case they would see fit, a prerogative which would make the process of reviewing the pharmaceutical applicant of patenting approval more complex. However this was a calculated step of the Indian Parliament to make sure that public health is the first priority of every decision of the Indian Patent Controller. However, on the other hand, it can be argued that the vast opportunity of opposing the grant of patent would increase the litigation in the Indian courts.

Another step was in the Indian non-enforcement of data exclusivity. Usually before a drug receives marketing approval from the regulatory authority, a sample of the drug has to be submitted for testing of quality, safety and effectiveness. ${ }^{501}$ Although the TRIPS Agreement demands of data exclusivity in the fields of pharmaceutical agriculture and chemical from unfair commercial marketing, ${ }^{502}$ it still allows the use of the submitted sample to assure protection of the public. ${ }^{503}$ Only recently, the Indian Government has acknowledged its obligation under the TRIPS Agreement to enforce data exclusivity (a step which can be presumed was taken due to the pressure from the United States). ${ }^{504}$ However the recommendation to enforce this mechanism was designated to only five years, which can still promise to some extent, an early entrance of generic competition to the marketplace. ${ }^{505}$ Nevertheless, it is to be noted that generic competition is still forbidden during the term of the 20 years patent protection which India has to ensure.

However, although the Indian Patent Act focuses on the right of the public for better health care through wider access to patented drugs, there were still growing

\footnotetext{
${ }^{500}$ See 35 USC s 311.

${ }^{501}$ See generally Conducting a Clinical Safety Review of a New Drug Product Application and Preparing a Report on the Review www.fda.gov (accessed 4 September 2009).

${ }^{502}$ See TRIPS Agreement, above n 1, art 39(3).

${ }^{503}$ Ibid.

${ }^{504}$ See Satwant Reddy, Gurdial Singh Sandhu Report on Steps to be taken by Government of India in the Context of Data Protection Provisions Of Article 39.3 of TRIPS Agreement (Prepared for the Government of India, 2007), para 7.4.3.

${ }^{505}$ Ibid.
} 
concerns by different civil organisations, fearing the rising prices of drugs due to patent enforcement. ${ }^{506}$ Dean referred in his note to Dr Hamied, the chairperson of the Indian pharmaceutical firm Cipla, expression towards patent as a tragic case for the Indian population's need to access patented drugs for HIV/AIDS. ${ }^{507}$ On the other hand, multinational entities argued that patent protection over pharmaceuticals will encourage innovation and invite new drugs into the markets in developing countries. ${ }^{508}$ Moreover these commentators argued that given the various flexibilities in the TRIPS Agreement countries should not fear accessing drugs in times of need. ${ }^{509}$

It is indisputable that wealthier countries had much more to gain from the TRIPS Agreement implementation than other countries, specifically developing and least developed countries. ${ }^{510}$ The former countries have the capital needed for high cost investment in the pharmaceutical industry, the scientific skills and now no one could risk their ownership on their invented products by copying them and set forward aggressive competition as generics. Nevertheless, since India's obligation to offer full patent protection in the pharmaceutical technology field, it experienced growing benefits of increased collaboration with foreign pharmaceutical firms in both generics and innovative framework. ${ }^{511}$ As other developing countries prior to signing the TRIPS Agreement, so did India decided that the benefits outweigh the costs and that international trade in addition to participating in the World Trade Organisation was a key of its economic growth. ${ }^{512}$

The growth of the industry since its 1970 Patents Act is indisputable. No one can deny that the new industry progressed considerably with a solid prospect of becoming a part of the innovative research and development international pharmaceutical

\footnotetext{
${ }^{506}$ See Mueller, above n 311, 529. See also The Impact of India's Amended Patents Act to Access to Affordable HIV Treatment www.healthgap.org (accessed 1 October 2009). See also Shubham Chaudhuri, Pinelopi Goldberg and Panle Jia "Estimating the Effects of Global Patent Proteciton in Pharmaceuticals: A Case Study of Quinolones in India" (2004)1, 43 www.nber.org (accessed 24 September 2009). See also Dean, above n 82, 732.

${ }^{507}$ See generally Dean, above n 82, 732 .

${ }^{508}$ Ibid, 734.

${ }^{509}$ Ibid.

${ }^{510}$ See Chaisse, Guennif, above n 360, 19.

${ }^{511}$ See generally Singham, above n 390, 375-378.

${ }^{512}$ See Harrelson, above n 319, 189.
} 
industry. ${ }^{513}$ Nevertheless, despite the growing innovative skills and investment in the process of research and development, Indian firms are still weak if compared to pharmaceutical multinationals which imposes serious challenges to the prospect of the local innovative industry evolvement and the opportunity to offer low cost patented drugs. ${ }^{514}$ However, with higher inflows of technology transfer into the Indian pharmaceutical industry, India may complete its transformation of becoming an innovative based pharmaceutical industry, grow and increase the local competition which, in turn, would lead to patented drug pricing reduction.

It is noteworthy that recommending wider enforcement of patent protection in the pharmaceutical technology field is not to support generics abolishment. The generic competition has a considerable and direct impact on reducing drugs pricing in the marketplace. However, in a try to build a more sophisticated pharmaceutical industry, using only generics is not the right choice, especially due to the effect it has on the Western world's willingness to keep India in the loop of the international trade. Undoubtedly, the Indian industry is ambivalent between the need to maintain constant access to drugs through high use of the TRIPS Agreement flexibilities and the wish to partner with pharmaceutical multinationals, which do not promote vast use of these flexibilities, and become a part of the international research - based pharmaceutical industry.

Although there seems to be a conflict, there is not. India has to strengthen its pharmaceutical industry and build a solid innovative capacity, aside from generics. India can see the benefits promised by a wider enforcement of intellectual property rights, especially in the pharmaceutical industry. Since signing the TRIPS Agreement, India has succeeded in attracting technology transfer inclusive of the pharmaceutical industry ${ }^{515}$ in a way which clearly indicates of the potential to empower the Indian "pharmahouse".

\footnotetext{
${ }^{513}$ See generally P M Rao "The Emergence of the Pharmaceutical Industry in the Developing World and its Implications for Multinational Enterpeise Strategies" (2008) 2 (2) International Journal of Pharmaceutical and Healthcare Marketing 103, 105 -107.

${ }^{514}$ Ibid.

${ }^{515}$ See generally Hindman, above n 325, 478.
} 
Pharmaceutical multinationals are not as fearful of the generic industry in India as prior to signing the TRIPS Agreement. They are not in fear for their costly technology and thus they are more willing to take advantage of the Indian quality and low cost services and in return, teach the local pharmaceutical industry their innovative skills. Ultimately, the new advanced technologies' penetration to the industry will be enforced by local firms. Trained scientists will wish to be a part of the growing industry; ${ }^{516}$ the local industry will grow, offer more drugs into the marketplace and naturally build such a competition that would assist to reduce the prices of drugs in the marketplace. ${ }^{517}$

The next chapter analyses this potential. It analyses the potential patent has in creating a platform of affordable drugs in India through the role it plays as an accelerator of international technology transfer. ${ }^{518}$ Although until the 1990s, India was not in a position to allow it to enjoy patent enforcement as a power to industrialise its pharmaceutical innovative capacity, for it did not have innovative skills at all, it cannot be said today. It is not that India does not see the potential of patent to build a larger and stronger innovative pharmaceutical industry as much as it does not see it as a tool to reduce the price of drugs. This can be learned from India's wish to narrow its enforcement and exclude pharmaceutical incremental innovation from the patent scope. This perception needs to be corrected.

First there is a need to strengthen the Indian pharmaceutical industry foundation. There is a need to enlarge it and invite more firms to activate in innovation. With patent as a motivator of technology transfer, collaboration with pharmaceutical multinationals, the opening of subsidiaries in India, outsourcing manufacturing to India, the local industry would enjoy growing knowledge and skills. Thus, with wider

\footnotetext{
${ }^{516}$ See Dean, above n 82, 734.

${ }^{517}$ See Douglas Lippoldt "Can Stronger Intellectual Property Rights Boost Trade, Foreign Direct Investment and Licensing in Developing Countries" in Meir Perez Pugatch (ed) The Intellectual Property Debate Perspectives from Law, Economics and Political Economy (Edward Elgar Publishing, Massachusetts, 2006) 44,48. See also Adamos Adamou, Subash Sasidharan "The Impact of R\&D and FDI on Firm Growth in Emerging - Developing Countries: Evidence from Indian Manufacturing Industries" (2007) 1,7 www.papers.ssrn.com (accessed 8 January 2009). See also Sourav Chatterjee and others "Intellectual Property Rights in Developing Nations"1,8 www.iipi.org (accessed 31 January 2009).

${ }^{518}$ See Maathai K Mathiyazhagan, Dukhabandhu Sahoo "Do Foreign Direct Investment Inflows Benefit the Major Sectors in India?" (2008) 38 Institute of South Asian Studies 9,13,18. www.isas.nus.edu.sg (accessed 13 April 2009).
} 
innovative skills, not only the 10 leading firms in the Indian pharmaceutical industry would practice in innovation but also the entire 10,000 firms, medium to small sized. ${ }^{519}$ Allocating the entire industry to practice in innovation, necessarily would increase competition, and offer lower cost patented drugs.

The following chapter sketches the process of technology transfer in the form of foreign direct investment, its potential to enlarge the Indian pharmaceutical industry and the role patent plays to promise this possibility. The chapter then concludes with the urgency for India to patent pharmaceutical incremental innovation in order to overcome the competition China imposes on its chances to attract foreign direct investment and delay the possibility to form extensive price reducing competition of patented drugs.

\footnotetext{
${ }^{519}$ See Padmashree Gehl Sampath "India's Pharmaceutical Sector in 2008, Emerging Strategies and Global and Local Implications for Access to Medicine" (2008) 1, 14, 24 www.dfid.gov.uk (20 September 2009).
} 


\section{PATENT AS DRUGS COMMODITISING STARTEGY IN DEVELOPING COUNTRIES}

Extensive innovative - based drugs competition in the marketplace cannot be created by 10 firms, 20 or even 100. India does not have to settle for these small numbers also. It has 10,000 pharmaceutical firms which, if encouraged to engage in innovation rather generics, there is a chance that the pharmaceutical competition in the Indian marketplace would grow to such an extent it would influence drug pricing. The only question is how? How can India fulfill its potential as a growing economic giant? How can the sophisticated Indian pharmaceutical industry increase its potential without the knowledge or the capital entailed with pharmaceutical research and development? How could a patented - based pharmaceutical competition be formed? A large part of the answer lies in the help pharmaceutical multinationals can offer to the Indian pharmaceutical industry, however not without patent enforcement in return.

The Indian pharmaceutical industry has much to gain from collaborating with Western firms. India's limited capital to invest in research and development can be assisted by Western technology and skills and in return offer quality low cost services of research and development and manufacturing. Furthermore, the same is relevant to India's attempt to expand its innovative technological capacity. ${ }^{520}$ In an attempt to benefit from India's low cost services, Western pharmaceutical firms open subsidiaries in India and research based facilities, hire Indian sophisticated low cost workforce and collaborate with Indian pharmaceutical firms. ${ }^{521}$ This way, pharmaceutical multinationals transfer the needed technologies to the Indian pharmaceutical industry. This "push and pull" mechanism practiced by the localforeign parties, ultimately can build a stronger and empowered Indian pharmaceutical industry. ${ }^{522}$ Not only will the new industry be able to conduct large scale research activity and enlarge the competition in the marketplace, it will have the necessary

\footnotetext{
${ }^{520}$ See Carlos M Correa "Can the TRIPS Agreement Foster Technology Transfer to Developing Countries?" in Keith E Maskus, Jerome H Reichman (eds) International Public Goods and Transfer of Technology Under Globalized Intellectual Property Regime (Cambridge University Press, New York, 2005), 229.

${ }^{521}$ See generally Todaro, Smith, above n 11, 720. See also Lanjouw, above n 121, 17.

${ }^{522}$ See Marcelo Jose Braga Nonnenberg, Mario Jorge Cardoso de Mendonca "The Determinants of Direct Foreign Investment in Developing Countries" (2004) 1, $11-12,15$ www.anpec.org.br/encontro2004/artigos/A04A061 (accessed 30 August 2009).
} 
innovative skills to research on tropical diseases and focus on a specific need for drugs in India.

Since India is obliged to offer patent protection for pharmaceutical products as well as processes, it is not advisable to base its production line only on generics' production. In order to be a part of the global flourishing pharmaceutical industry, India has to engage in innovation in addition to the imitation process of drugs. Moreover, it is important to emphasise that generics will neither assure better healthcare in India nor offer the progression the local industry needs to advance its innovative skills or establishing low cost patented drug market.

The economic turmoil the world has been through in the past two years has not passed the pharmaceutical industry. ${ }^{523}$ Together with the increasing regulatory demands by the Food and Drug Administration in the United States, ${ }^{524}$ the pharmaceutical industry suffered from a reduction of the capital available to invest in further complex research and development. ${ }^{525}$ Some firms even find themselves threatened to pursue the approval of their researched drugs. ${ }^{526}$ This reality can strengthen the propensity Western pharmaceutical firms may find in India's pharmaceutical industry, to reduce the costs involved in the process of research and development. ${ }^{527}$ In other words, Western pharmaceutical firms could find in India a low cost platform for both manufacturing and research activities. ${ }^{528}$

Commentators foresee that by the year 2010, the Indian pharmaceutical industry will be worth US\$9.48 billion. ${ }^{529}$ Moreover, given that the Indian industry is exceptionally large, has a skilled workforce and a low cost research and development production process, India can be a potential partner for the Western pharmaceutical industry. $^{530}$

\footnotetext{
${ }^{523}$ See Pharma Revenue Struggles as Patents Expire www.businessday.co.nz (accessed 18 November 2008).

524 Ibid.

525 Ibid.

526 Ibid.

${ }^{527}$ See generally Rao, above n 513, 107-110.

${ }^{528}$ See generally Asia Pacific to Replace United States and Europe as Pharmaceutical Industry

Powerhouse www.primenewswire/newsroom/news (accessed 3 September 2009).

${ }^{529}$ See Palit, Bhattacharya, above n 215, 85.

${ }^{530}$ See Chaturvedi, Chataway and Wield, above n 10, 572.
} 
In their research, Maskus and Reichman stressed the importance of trading ideas for developing countries to form stronger economies. ${ }^{531}$ Nevertheless, without patent protection, the notion of trading ideas will not take place, ${ }^{532}$ especially in the pharmaceutical industry which is exceptionally exposed to copying. As shown earlier, the lack of patent enforcement prior to the TRIPS Agreement pushed multinational pharmaceutical firms away from the infringing markets in developing countries. ${ }^{533}$ The fact that India could offer low cost services was not enough for Western firms in the past and it will not be enough in the future. India, as well as other developing countries, suffered from extensive trading sanctions which distanced it from obtaining "new ideas" for development. This is to teach of the strong connection patent enforcement has in regards to advancing developing countries through new technologies and the possibility to enlarge the local competition, one which naturally can influence drug pricing.

Since signing the TRIPS Agreement, the Indian pharmaceutical industry has enjoyed vast forms of collaboration with Western pharmaceutical firms. Firms opened different subsidiaries, hired local firms for manufacturing processes and open research and development facilities across the country. Needless to say that through a high volume of investment, higher education of pharmaceutical research and development is promised to the local industry as well as its expansion. If India did not have much to gain from collaborating with Western firms in the past, for it lacked even the minimal innovative skills, its capabilities in the innovative avenue today allow it to benefit from collaborating with Western firms and form a larger industry.

India was not chosen randomly as a case study. As much as for India's economy, politics and infrastructure characteristics together with its medium advanced pharmaceutical industry, India has been successful in attracting collaboration with foreign pharmaceutical firms. However none of these aforementioned merits could have been practical without finally introducing patent enforcement of pharmaceutical products. As Hindman stated in his note 80 per cent of chemical firms would not

\footnotetext{
${ }^{531}$ See Maskus, Reichman, above n 120, 11.

532 Ibid, $12,14$.

${ }^{533}$ See Part IV B Generics Fall and Innovation Rise.
} 
invest in India for the lack of insufficient intellectual property rights protection enforcement. $^{534}$

The first part of the chapter analyses the potential technology transfer has in enlarging the Indian pharmaceutical industry in the form of foreign direct investment. Finding that Western firms need partners to conduct research and development processes due to economic-regulations growing difficulties, foreign direct investment is found to be a constructive tool both to the Indian pharmaceutical industry interests as well as to the Western's. India's economic and technological characteristics offer the right platform for high inflows of foreign direct investment. However, as discussed in the second part of the chapter, attracting foreign direct investment requires patent enforcement, especially in the pharmaceutical industry. Lastly, as a complementary addition to the discussion of the importance of enforcing patent protection on pharmaceuticals in India, the third part of the chapter presents the growing competition India has with China for foreign investment, a risk India cannot afford if it wishes to find a solution to low cost drugs in the frame of patent.

\section{A. Commoditisation of Drugs Through International Technology Transfer:}

\section{Application to Foreign Direct Investment}

Currently, in India, there are only 11 firms which are engaged with new chemical entity drugs research and development, which can exemplify the lack of large scale innovative skills in the Indian pharmaceutical industry. ${ }^{535}$ The Indian pharmaceutical firm Cipla, which is the fourth largest spender on research and development in India, does not engage in new chemical entity drugs research and development. ${ }^{536}$ Most research and development expenditure in the pharmaceutical industry in India is designated to generics and incremental modified drugs, however, not to a great extent. $^{537}$

\footnotetext{
${ }^{534}$ See Hindman, above n 325, 474.

535 See generally Chaudhuri, above n 176, 4.

536 Ibid, 5.

537 Ibid.
} 
The trend of research and development of new chemical entity drugs started since India signed the TRIPS Agreement. ${ }^{538}$ Since the Indian pharmaceutical firm Dr Reddy initiated the research followed by Ranbaxy, nine other firms have joined the trend and today, these 11 firms represent the highest investors in the process of research and development of new chemical entity drugs. ${ }^{539}$ Although their investment increased in 2005-06 to US\$379 million together, ${ }^{540}$ this amount is hardly adequate for research and development in the pharmaceutical industry which often demands higher expenditures of US\$1 billion. ${ }^{541}$ The reason for the monumental gap between Western firms' investment and Indian firms lies in the lack of skills and funds available to the Indian pharmaceutical industry, ${ }^{542}$ which can be remedied through collaboration with Western pharmaceutical firms.

Although Chaudhuri acknowledged the small change in the innovative nature of the Indian pharmaceutical industry, he did appreciate the potential it has to grow. ${ }^{543}$ With the right partnering with more advanced pharmaceutical firms, to educate the Indian industry, the Indian population may see a time when the competition in the marketplace reduces drugs pricing.

\section{The Indian pharmaceutical industry need of investment-further observations}

Access to patented drugs through generics is not an option for the Indian generic pharmaceutical industry anymore or to any other member country of the World Trade Organisation. ${ }^{544}$ Under patent protection, all generics copying were delayed to the end of the 20 years protection term. In other words, the TRIPS Agreement forced developing countries such as India to adopt an innovative orientation to their pharmaceutical industry. ${ }^{545}$ Although many feared the potential increase of drug' pricing, the TRIPS Agreement as well as the Doha Declaration did not leave any developing member country of the World Trade Organisation without the possibility

\footnotetext{
${ }^{538}$ Ibid, 6.

${ }^{539}$ Ibid.

${ }^{540}$ Ibid.

${ }^{541}$ See Part III A New Chemical Entities.

${ }^{542}$ See generally Chaudhuri, above n 176, Ibid, 6-7.

${ }^{543}$ Ibid, 4,9 .

${ }^{544}$ Nevertheless, as the TRIPS Agreement offered, there are several exceptions to the patentee exclusive rights over the invention.

${ }^{545}$ See generally Chaturvedi, Chataway and Wield, above n 10, 573.
} 
to access drugs when needed and introduced several exceptions to the patentee's exclusivity rights in the marketplace like compulsory licensing. ${ }^{546}$

Although the productivity of the various flexibilities in the TRIPS Agreement is substantial in regards to making drugs affordable to the poor, often use of these flexibilities as a route to access drugs is not recommended. The extreme pressure forced on developing countries to adopt the TRIPS Agreement and patent pharmaceutical products by the West does encourage a wide use of the exceptions to patent market exclusivity nature. ${ }^{547}$ As initially stated, establishing wide-ranging pharmaceutical innovative industry is not an overnight process. Respectively, and until one is formed in India, it is advised to use compulsory licensing, for example, to answer a current need for drugs by the public, as an exceptional not as a normative rule.

Under an extensive use of "patent exceptions", the utilisation of patent cannot be fulfilled. If India finds itself using these flexibilities excessively, it would appear in the eyes of the West as an untrustworthy partner just as in the time prior to the TRIPS Agreement settlement. ${ }^{548}$ This would not enable the formation of a low cost patented drug market in India. India needs to build for itself a name as a proactive party to the world's pharmaceutical industry, attract more investment, offer new technologies and become a party to the international trading scheme, ${ }^{549}$ a scheme which can enhance the local industry's products outline.

Following to signing the TRIPS Agreement, India's Government understood it would not have only to reform its laws but the entire outline of its pharmaceutical industry. India understood it had to enforce an innovative industry, one which would be able to become one with the international innovative industry. India first tried to seek progress through a wider endorsement of private-public collaboration. ${ }^{550} \mathrm{Just}$ as

\footnotetext{
${ }^{546}$ See TRIPS Agreement, above n 1, art 31. See also the Doha Declaration, above n 16, art 5.

${ }^{547}$ As initially stated in the opening of the paper, establishing a wide-ranged pharmaceutical innovative industry is not an overnight process. Respectively, and until one is formed in India, it is advised to use compulsory licesing for example to answer a current need for drugs by the public, as an exceptional not as a normative rule.

${ }^{548}$ See Part IV B Generics Fall and Innovation Rise.

${ }^{549}$ See Kale, Little, above n 253, 599.

${ }^{550}$ See generally Dhar, Gopakumar, above n 179, 50 .
} 
Japan has successfully emerged its pharmaceutical industry through private-public collaboration, ${ }^{551}$ India's Government tried to encourage this level of collaboration through taxation exemptions as well as price control exemptions. ${ }^{552}$ One of the most important achievements of the Pharmaceutical Research and Development Council established in $1999^{553}$ was the setting up of the Drug Development Promotion Foundation. ${ }^{554}$ This foundation, managed by both the private sector and the Government, encouraged focus on enhancing basic research skills, new drugs delivery options and providing international co-operation. ${ }^{555}$

The results were quickly noticeable. More firms joined the academic sector research, more laboratories were established, universities and colleges, all to achieve the goal of larger Indian pharmaceutical innovative products, aside from generics. ${ }^{556}$ As of today, much emphasis is put on the private-public collaboration, especially concerned with the research on the neglected group of diseases such as tropical diseases. ${ }^{557}$ Two of the main success stories of these initiatives are demonstrated in the Medicines for Malaria Venture and the Global Alliance for Tuberculosis, both registered organisations by the private and the public pharmaceutical sectors. ${ }^{558}$ Nevertheless, these are only two researched diseases out of tens of neglected diseases which demand further research to improve developing countries healthcare. ${ }^{559}$

In time local firms have started to see their obligation to fulfil a competitive edge and have started upgrading their innovative research and development activity. ${ }^{560}$ However, they were not to fulfil this end only through local public-private collaboration. India's pharmaceutical industry does not have the innovative skills or the advanced technology needed in larger innovative activity. This reason has made India become more accepting of Western-Indian collaboration. Indian firms started to

\footnotetext{
${ }^{551}$ See generally Lee G Branstetter "Do Stronger Patents Induce More Local Innovation? in Keith E. Maskus, Jerome H. Reichman (eds) International Public Goods and Transfer of Technology Under Globalized Intellectual Property Regime (Cambridge University Press, New York, 2005), 316.

${ }^{552}$ See generally Dhar, Gopakumar, above n 179, 51.

${ }^{553}$ Ibid.

554 Ibid.

555 Ibid, 51-52.

${ }^{556}$ Ibid, 51.

${ }^{557}$ See generally Trouiller and others, above n 59, 2192.

558 Ibid.

559 Ibid.

${ }^{560}$ See generally Chaturvedi, Chataway and Wield, above n 10, 573.
} 
see the potential in acquiring Western firms with existing innovative products and research and development based facilities to learn and influence markets geographically and therapeutically. ${ }^{561}$

Research and development expenditures by Indian pharmaceutical firms grew from 2 per cent to about 7-8 per cent in recent years, ${ }^{562}$ from US\$51.7 million in 1995 to US\$339.7 million in $2004 .{ }^{563}$ Since the mid 1990s Indian pharmaceutical firms such as Dr Reddy's ${ }^{564}$ and Nicholas Piramal India Limited (NPIL) ${ }^{565}$ invested more in research and development and implemented new production methods like the novel drug delivery system which is based on incremental modified drug innovation. ${ }^{566}$ The Indian pharmaceutical firm Dr Reddy's, which started as a generic producer, ${ }^{567}$ regularly invested 12 per cent of its profits in research and development. ${ }^{568}$ Medium sized Indian pharmaceutical firms such as Glenmark pharmaceuticals Ltd $^{569}$ also invested increasingly in research and development. ${ }^{570}$ As of today, Glenmark is considered to be one of the highest investors in research and development in the Indian pharmaceutical industry. ${ }^{571}$ More and more firms followed these leading Indian pharmaceutical firms, engaging with foreign firms in manufacturing contracts. ${ }^{572}$ The Indian industry showed signs of becoming a part of the growing global innovative pharmaceutical industry. ${ }^{573}$

Leading pharmaceutical firms also saw the potential of expanding their benefits and their innovative capacity through acquiring foreign firms based in the developed world. Ranbaxy, for example, purchased Ohm Laboratories in the United States, ${ }^{574}$ giving it the opportunity to enjoy advanced sophisticated facilities and workforce. Obviously, the new welcoming of local-foreign pharmaceutical platform has

\footnotetext{
${ }^{561}$ Ibid, 575-576, 580.

562 Ibid, 575.

${ }^{563}$ Dhar, Gopakumar, above n 179, 34.

${ }^{564}$ Dr. Reddy's www.drreddys.com (accessed 29 August 09).

565 See Nicholas Piramal India Limited www.nicholaspiramal.com (accessed 29 August 2009).

${ }^{566}$ See generally Chaturvedi, Chataway and Weild, above n 10, 572.

${ }^{567}$ See Dr. Reddy's www.drreddys.com/aboutus/aboutus (accessed 29 August 2009).

${ }^{568}$ See Chaturvedi, Chataway and Wield, above n 10, 565.

${ }^{569}$ See Glenmark Pharmaceuticals Ltd www.glenmarkpharma.com/about/index (accessed 29 August 2009).

${ }^{570}$ See generally Dhar, Gopakumar, above n 179, 35.

${ }^{571}$ Ibid.

572 Ibid, 573.

573 Ibid.

574 Ibid.
} 
substantially improved the local firms with innovative skills. The possibility to compete with foreign firms only further pushed Indian firms to adopt innovative orientation more than imitative. ${ }^{575}$

This review implies that the importance of the research and development process to introduce more innovative based drugs to the marketplace has been assimilated throughout the entire spectrum of the industry, ${ }^{576}$ however, not as much as it first appears and not as much as needed to treat the Indian industry as prepared to offer low cost patented drug market through extensive competition.

The majority of Indian pharmaceutical firms still invest only 1.9 per cent in research and development, relative to 10.16 per cent investment in the West. ${ }^{577}$ The low expenditures naturally cannot offer a high volume of innovative based drugs in the marketplace. Statistics show that most of the Indian firms of today invest in generics production and not even in incremental innovation which is a prime level of innovation in the pharmaceutical technology field. ${ }^{578}$ The pure reason is that they cannot. They do not know how. They do not have available capital to invest further in the low cost generic process.

Clearly, the existing investment in research and development is insufficient to form large competition in the Indian marketplace. There is a clear need to encourage more investment to enlarge the number of firms which practice innovation to increase the quantity of local produced innovative drugs in the marketplace. As long as only the small number of 10 firms engage in innovative research and development as centrally analysed in Chaturvedi's research, ${ }^{579}$ it is not likely that the local population will enjoy high quantity Indian patented drugs. Without the expansion of the local industry, the local market will not be able to offer extensive price reducing competition. As time passes, there is a need to take more productive steps to enlarge the Indian pharmaceutical industry to achieve this end. One prime option is through

\footnotetext{
575 Ibid.

${ }^{576}$ Ibid, 35-36. See also Chaturvedi, Chataway, Weild, above n 10, 581-582.

577 See Rai, above n 391, 406.

${ }^{578}$ See Kale, Little, above n 253, 599. Carsten Fink "How Strong Patnet Protection in India Might Affect the Behaviour of Transnational Pharmceutical Indistries" (2000) 1, 9 www.papers.ssrn.com (accessed 18 November 2008). See also Chaudhuri, above n 176, page 5.

579 See Chaudhuri, above n 176, page 4.
} 
foreign direct investment which directly impacts on the technological capacity of the recipient industry and the prospect to enlarge the local marketplace.

\section{Foreign direct investment potential to intensify local production - towards low} cost patented drug marketplace

The previous section showed that the current structure of the Indian pharmaceutical industry to reduce patented drugs cost is not optimal. The local industry does not have the capital or the knowledge to offer such a reality. Hence, if altered, if introduced with the needed technologies and skills, the possibility of the Indian industrial growth is assured. Recipient industries of foreign investment not only appreciate the power of the new technology, but also the education and training as a part of their prospective growth. ${ }^{580}$ Often commentators on technological transfer impact on a country's technological growth glorify the importance of training much more than the simple transfer of goods. ${ }^{581}$

Foreign direct investment was and still is treated as a strong tool to elevate the host country's economy through the advancement of its technology capacity. ${ }^{582}$ Foreign direct investment has long been perceived as "the most important...channel through which advanced technology is transferred to developing countries". ${ }^{83}$ By purchasing assets, merging with local firms, forming joint ventures and investing in equipments, ${ }^{584}$ foreign direct investment exposes the local industry to what is called "productivity spillovers". ${ }^{55}$ This phrase refers to the different benefits which are promised to local industries through foreign investment, ${ }^{586}$ especially in newly industrialised countries, such as India. ${ }^{587}$

With exposure to newly advanced products and technology the Indian pharmaceutical industry will have a sophisticated technology to imitate and adopt for

\footnotetext{
${ }^{580}$ See generally Assad Omer, above n 116, 555.

${ }^{581}$ Ibid, 561.

582 See Hindman, above n 325, 468-470, 477.

${ }^{583}$ Trade and Foreign Direct Investment www.wto.org (accessed 8 January 2009).

${ }^{584}$ See Hindman, above n 325, 470.

${ }^{585}$ See generally Magnus Blomstrom, Ari Kokko and Mario Zejan Foreign Direct Investment: Firm and Host Country Strategies (Palgrave, New York, 2000) 101.

${ }^{586}$ See Adamou, Sasidharan, above n 517, 7. See also Hindman, above n 325, $470-471$.

${ }^{587}$ See Shireen AlAzzawi "Foreign Direct Investment and Knowledge Inflows: Evidence from Patent Citations" (University of California, Davis, 2004), para 6.
} 
its own independent research and development. ${ }^{588}$ The industry will also benefit from new sophisticated managerial skills ${ }^{589}$ and a direct impact on the labour turnover. ${ }^{590}$ The exposure to new technologies ${ }^{591}$ will drive many scientists to take the new technology and open their own enterprises to participate in the growing competition. ${ }^{592}$ This latter avenue clearly demonstrates the potential foreign direct investment has in expanding the Indian pharmaceutical industry through development and placing the competitive platform needed to allocate a low cost patented drug marketplace.

A sophisticated industry will also be driven to produce more quality products. ${ }^{593}$ As foreign firms introduce quality products and technologies to the local marketplace, the local Indian pharmaceutical industry will wish to compare its product line to the foreign and not lag behind it. Thus the Indian pharmaceutical industry will be more motivated to invest in research and offer better and more quality drugs products than the foreign. 594

Clearly collaborating with Western large and advanced pharmaceutical firms would elevate the Indian innovative pharmaceutical industry. This result is a key factor in offering a low cost patented drugs market. As long as the entire industry enjoys innovative skills it will be able, after absorbing enough technology, to introduce a high volume of innovative based drugs, incremental and pioneer. The current number of Indian firms engaging in innovation is insufficient to exercise a larger innovative pharmaceutical marketplace. However with further ventures with the West, the potential in fulfilling this end is apparent. Through larger innovative capacity, India will not have to wait for others to innovate before accessing a drug. India will not have to wait to the end of the patent protection term to access drugs.

\footnotetext{
${ }^{588}$ See Adamou, Sasidharan, above n 517, 7. See also Blomstrom, Kokko and Zejan, above n 585, 103. See also Chaturvedi, Chataway and Wield, above n 10, 583-584.

${ }^{589}$ See Blomstrom, Kokko and Zejan, above n 585, 101.

${ }^{590}$ See Adamou, Sasidharan, above n 517, 7.

${ }^{591}$ See generally Blomstrom, Kokko and Zejan, above n 585, 111, 120.

${ }^{592}$ See Adamou, Sasidharan, above n 517, 7. See also Blomstrom, Kokko and Zejan, above n 585, 111, 119.

${ }^{593}$ See Adamou, Sasidharan, above n 517, 8.

${ }^{594}$ See Adamou, Sasidharan, above n 517, 8. Needless to say that upgrading the local productivity quality and enjoying from the support of Western pharmaceutical multinationals would be economic wise for it would ease the Indian products marketing process in foreign markets. See in this regards Chaturvedi, Chataway and Wield, above n 10, 582.
} 
India will have the necessary skills to innovate itself and given its growing economy and consumer market in health, the possibility to form a competitive platform of pharmaceuticals and offer low cost patented drug can be a possibility

\section{The West propensity to the Indian pharmaceutical industry}

India is a good example of a host country for foreign direct investment, especially in the pharmaceutical industry. However, before answering that aspect, there is one factor which demands further consideration and that is the Western pharmaceutical industry tendency to invest in country such as India. Despite the growing research and development investment by pharmaceutical multinationals, the Food and Drug Administration approved the small number of only 17 new chemical entity based drugs in $2002 .^{595}$ This small amount can be partly due to economic difficulties the pharmaceutical industry is experiencing.

At the Israel Life Science Industry - Biological and Medical Conference and Exhibition 2009 (ILSI-BIOMED), ${ }^{596}$ various specialists have consensually agreed that these days, the Western pharmaceutical industry suffers from a substantial economic and scientific crisis. This economic reality can encourage the industry to find partners to share the costly investment in research and development in developing countries such as India. ${ }^{597}$ India as further observed in the next section and as comprehensively analysed earlier, ${ }^{598}$ can offer low cost research and development (40 per cent - 60 per cent lower than in Western countries), ${ }^{599}$ educated low workforce cost, ${ }^{600}$ vital elements to the Western economic struggling pharmaceutical industry.

Dr Lee Babiss, Head of Global Pharma Research F Hoffmann-La Roche Inc, home based in Switzerland, who during the ILSI-BIOMED conference gave a

\footnotetext{
${ }^{595}$ Chaturvedi, Chataway and Wield, above n 10, 582.

596 The Israel Life Science Industry - Biological and Medical Conference and Exhibition 2009 [ILSIBIOMED] is an annual international conference, mostly taking place in Israel. The conference covers the fast-growing field of innovation in the biomedical, health care and life sciences industries and involves with a large scale of experts, international CEOs, academics, scientist and researchers. ILSIBioMED www2.kenes.com/biomed/Pages/Home (accessed 26 Octoeber 2009).

${ }^{597}$ See Keith E Maskus "Intellectual Property Challenges for Developing Countries: An Economic Perspective (2001) U Ill L Rev 457, 459. See also Chaturvedi, Chataway and Wield, above n 10, 582.

${ }^{598}$ See Part V A 4 India as a host country of foreign direct investment.

${ }^{599}$ Muller, above n 311, 500. See also Chaturvedi, Chataway and Wield, above n 10, 582.

${ }^{600}$ Ibid.
} 
presentation on Roche's strategy for its pharmaceutical product pipeline, primarily stressed the importance of diversification innovation models around the world. ${ }^{601} \mathrm{Dr}$ Babiss mentioned that by the year 2008, Roche increased its external innovation collaboration both with China and India from 38 contracts in 2003 to 57 in $2008 .^{602}$ He called the Western industry not to be afraid of a change and encouraged smart alignments and external innovation. ${ }^{603}$ He eloquently ended his presentation when he said "different cultures bring different cultures to science". ${ }^{604}$

India can be that partner, not only for offering a high quality of scientific capacity, but also for offering it at such a low cost which can reduce the risks the Western industry faces in research and development. The change that the Indian innovative industry has gone through was apparent and presented a substantial motivator for pharmaceutical multinationals to see in India an innovative partner to reduce the cost of research and development.

Dr Hadar Ron from Israel Healthcare Ventures Ltd, who also participated in the conference, addressed another avenue which hardens the platform of research and development for the Western pharmaceutical industry. ${ }^{605}$ This avenue is the high safety level regulations recently introduced by the United States Food and Drug Administration. Dan Mendelson, the president and the founder of Avalere Health LLC, ${ }^{606}$ a firm in the United States which offers consultation services in health care and Government regulations, gave a presentation on the same issue, "The Face of Change: Regulation, Legislation and the US Markets". 607

Mendelson determined that the safety - benefits tension, or in other words the regulation-reimbursement tension has substantially increased in the last few years and is about to increase even more. One recent example for the changed atmosphere in the

\footnotetext{
${ }^{601}$ Dr. Lee Babiss, Head, Global Pharma Research F Hoffmann-La Roche Inc, "Roche Strategy for its Pharma Product Pipeline" (2009 ILSI-BIOMED, Israle, 16 June 2009).

${ }^{602}$ Ibid.

603 Ibid.

604 Ibid.

${ }^{605}$ Dr Hadar Ron, Managing Director, Israel Healthcare Ventures "Investment Strategy In Time of Crisis" (2009 ILSI-BIOMED, Israle, 15 June 2009).

${ }^{606}$ See Avalere Health LLC www.avalerehealth.net (23 October 2009).

${ }^{607}$ Dan Mendelson, President\& Founder, Avalere Health LLC "The Face of Change: Regulation, Legislation and the US Markets" (2009 ILSI-BIOMED, Israle, 16 June 2009).
} 
United States market is the United State Congress passing in 2007, the Food and Drug Administration Amendments Act of 2007 (FDAAA). ${ }^{608}$ Overlooking key pharmaceutical programs, such as the Prescription Drug User Fee Act, the Medical Device user Fee and the Modernisation Act, the FDAAA comprehensively changed the familiar set of regulations in the pharmaceutical technology field. ${ }^{609}$ The FDAAA also encourages private - public partnerships, enhances food and drug safety provisions and expands clinical trials database. ${ }^{610}$ FDAAA allows the Food and Drug Administration to require post approval clinical trials sample submissions to assess the safety of the marketed drug. ${ }^{611}$ FDAAA also enables the Food and Drug Administration to label changes to the marketed drug if it was found that new safety requirements are due to be introduced. ${ }^{612}$

The FDAAA obliges enlarged registry in the clinical trials databases for all clinical trials that are on going. ${ }^{613}$ The FDAAA demands that data such as demographics be submitted, as well as primary and secondary clinical trials results. If these requirements are not answered, monetary penalties will be forced on civil organisations. ${ }^{614}$ According to Messplay and Burrell, these aforementioned factors, which accompanied with additional factors such as paediatric research and enhanced drug user fees, can severely impact on the pharmaceutical industry willingness to engage with sophisticated pharmaceutical research and development. ${ }^{615}$

With a legal obligation to show therapeutic and economic efficacy as discussed, firms are going to have to use larger capital for the research and development process. Overall with not enough funding, high risks of failure, high competition, small reimbursement expectancy, small amount of drugs in the pipeline, growing demands for efficacy and safety, hardens the chances for pharmaceutical firms in the developed world to survive without sharing the research and development economic risks with

\footnotetext{
${ }^{608}$ See Food and Drug Administration Amendments Act of 2007 Pub L No 110-85, 110 Stat 823 (2007).

${ }^{609}$ See Gary C Messplay, Sarah E Burrell "Implications of FDAAA 2007 Changes are A foot Following the FDA's Reauthorization" www.fda.gov (accessed 20 September 2009).

${ }^{610}$ Ibid.

${ }^{611}$ Ibid.

612 Ibid.

613 Ibid.

${ }^{614}$ Ibid.

${ }^{615}$ Ibid.
} 
others. India seems to be a potential good partner. ${ }^{616}$ As firms would have to show efficacy using the lowest cost as possible, the tendency to make alliances with a capable industry such as India which offers research and manufacturing services at a low cost, is obvious and encouraged. Under these alliances as discussed earlier, the prospective benefits for the Indian pharmaceutical industry are immense.

Correa however, doubts the incentive Western firms have to transfer their advanced technologies even indirectly to developing countries. He based his doubts purely on the fact that with Western support and education programs, industries in developing countries would be strong competitors to Western. ${ }^{617}$ One reply to this concern is that although the competition platform would increase, Western pharmaceutical firms still need to find a way to reduce the expenditure in the pharmaceutical research and development. The difficulties in inventing a new chemical entity drug or new molecular entity drug which promise the highest returns, ${ }^{618}$ the narrower pipelines ${ }^{619}$ and the intensive safety regulations introduced by the Food and Drug Administration, all force the Western industry to share the "spotlight" with foreign pharmaceutical industries in the developing world and take the chance of establishing a new strong competitor in the global marketplace.

From India's perspective, the Indian Government understood the capacity of foreign direct investment and the positive impact it has on the growth of its pharmaceutical industry. ${ }^{620}$ This was an understanding that the Indian industry has implied by liberalising its policies in regards to foreign direct investment in the 1990s (just before signing the TRIPS Agreement). ${ }^{621}$ Without any restrictions on foreign direct investment in the pharmaceutical sector, ${ }^{622}$ India is to fulfil its true potential and enlarge its pharmaceutical industry activity. ${ }^{623}$ However, the exceptionally small number of Indian firms collaborating with Western firms today, India's

\footnotetext{
${ }^{616}$ These concerns were raised by Antonie Papiernik in the 2009 ILSI-BIOMED. Antonie Papiernik, Managing Partner Sofinnova Partners, France "Investment Strategy In Time of Crisis" (2009 ILSIBIOMED, Israle, 15 June 2009).

${ }^{617}$ See Correa, above n 520, 229. See also Carlos M Correa "Trends in Technology Transfer Implocations for Developing Countires (1994) 21 Science and Public Policy 369.

${ }^{618}$ See generally Bruce, above n 231, 195.

${ }^{619}$ Ibid.

${ }^{620}$ See generally Rai, above n 391, 406. See also Chaturvedi, Chataway and Wield, above n 10, 575.

${ }^{621}$ See generally Rai, above n 391, 406.

${ }^{622}$ Ibid.

${ }^{623}$ See Chaturvedi, Chataway and Wield, above n 10, 575.
} 
pharmaceutical industry has not yet to achieve its potential to build an enlarged Indian pharmaceutical marketplace. Through Western-Indian collaboration, the Indian pharmaceutical industry will be supplied with the needed research skills to grow as suggested before and build an influential competitive platform ${ }^{624}$ to answer the public need for a better health care through affordable patented drugs.

Technology transfer has always been perceived as a main source in developing countries' industrialisation and infrastructure growth. ${ }^{625}$ However, it is noteworthy to mention that not all developing countries can benefit from it, as pointed out by Arora. ${ }^{626}$ Transactions of technology in the pharmaceuticals technology field are common. ${ }^{627}$ However, without the proper abilities to absorb the learned technologies, Western firms will not wish to invest and the recipient industry will not be projected to benefit. ${ }^{628}$ Correa also supported this observation. ${ }^{629}$ A country which lacks the minimal technological capacity in the pharmaceutical industry will not be able to offer beneficial returns to foreign direct investors through low cost quality services. Examining this aspect indicates once more India's substantial platform both to benefit from foreign direct investment and be beneficial for investors.

India of today is a rising economic force. ${ }^{630}$ With more than one billion population, ${ }^{631}$ the growing gross domestic products value, ${ }^{632}$ its exceptionally large market size, its efficient infrastructure ${ }^{633}$ and the educated English-speakers workforce, ${ }^{634}$ all indicate of India's potential to attract foreign direct investment into its markets and enjoy a productive collaboration with the West to enlarge its

\footnotetext{
${ }^{624}$ See Sherwood, above n 117, 503. See also Chadha, above n 264, 1. See also Blomstrom, Kokko and Zejan, above n 585, 103.

${ }^{625}$ See generally Correa, above n 520, 229.

${ }^{626}$ See Ashish Arora, Andrea Fosfuri and Alfonso Gambardella "Markets for Technology, Intellectual Property Rights, and Development" in Keith E Maskus, Jerome H Reichman (eds) International Public Goods and Transfer of Technology Under Globalized Intellectual Property Regime (Cambridge University Press, New York, 2005), 325.

${ }^{627}$ Ibid.

${ }^{628}$ See Maskus, Reichman, above n 120, 12.

${ }^{629}$ See Correa, above n 520, 230.

${ }^{630}$ See Muller, above n 311, 499.

${ }^{631}$ Ibid.

${ }^{632}$ Ibid.

${ }^{633}$ See Maskus, Reichman, above n 120, 13.

${ }^{634}$ See Muller, above n 311, 500. Muller added that in practice, there are 40 per cent more Indian graduates in science and engineering than in the United States, which can exemplify the potential of the Indian pharmaceutical industry attractiveness for foreign direct investment.
} 
innovative pharmaceutical industry. This avenue is next observed with further theory elaboration and empirical support. Concluding the two it is shown that India's characteristics can encourage foreign direct investment in a productive manner to fulfil the advocated alternative of a low cost patented drug market through the creation of vast local competition.

\section{India as a host country of foreign direct investment}

In his study Kumar Rai referred to the Ownership-Location-Internalisation (OLI) theory as the basic justification of foreign direct investment. ${ }^{635}$ According to the OLI theory, there are several inseparable factors to patent practice in a host country to attract foreign direct investment into a country. Factors, such as the size of the market in the host country, the local industry's infrastructure and the stability of the economic environment are not less important than patent protection enforcement. ${ }^{636}$ These factors were also supported by Nonnenberg and de Mendonca specifically in regards to developing countries' ability to attract high inflows of foreign direct investment ${ }^{637}$ and in Hindman's note as well. ${ }^{638}$ Observing India's economic factors, its exceptionally large market size, its relatively capable pharmaceutical industry in comparison to other developing newly industrialised countries, place India as having the right platform to attract foreign direct investment according to the OLI theory.

Correa's supported the logic behind the OLI theory while stressing that foreign direct investment inflows extensively depend on skills availability, technology status, research and development capacity, enterprise-level competence and the ability to complement modern technologies and institutional and technological infrastructure in the host country. ${ }^{639}$ Telecommunication infrastructure as well as a country's financial services also has strong positive impact on high flows of foreign direct investment into a host country. ${ }^{640}$ Naturally, without the aforementioned aspects, without the

\footnotetext{
${ }^{635}$ See Rai, above n 391, 409.

636 Ibid.

${ }^{637}$ See Nonnenberg, Mendonca, above n 522

${ }^{638}$ See Hindman, above n 325, 476.

${ }^{639}$ See Carlos M Correa Intellectual Property Rights, the WTO, and Developing Countries: the TRIPS Agreement and Policy Options (Zed Books, London, 2000). See also Maskus, Saggi and Puttitanun, above n 125, 268 - 269. See also Omer, above n 116, 561.

${ }^{640}$ See Maskus, Saggi and Puttitanun, above n 125, 268 - 269.
} 
economic stability, technological capacity and communication, what will be the use of foreign investment to the host country?

As much as protection of the foreign technology against copiers is needed, without a constructive partner to absorb the transferred technologies, there will not be any benefit for either party: the investor, or the recipient. Without understanding the process of research and development, the process of acquiring and implementing foreign technologies, using the new technologies will cost more and may not be economically sufficient for the host country. Without the host country's abilities to absorb the transferred technology, the investing country will have to invest more capital to overcome the difficulties in the host country. Foreign direct investment is based on mutual agendas. As the agenda of the host country is to use the advanced technologies to advance its industries, the agenda of the investing country is that the host country will be able to manufacture the advanced products for example. Without the capacity to understand the technology, foreign firms will not benefit and the process of foreign direct investment will be irrelevant to both sides. ${ }^{641}$

Based on the justifications above, the Indian pharmaceutical industry seems to be able to fulfill the two interests, its own and the foreign. Based on India's economic growth, scientific skills and its well based telecommunication infrastructure, ${ }^{642}$ the Indian pharmaceutical industry seems to fit the model of the OLI theory alongside with Correa's standards of the optimal host country to benefit from foreign direct investment.

Also the Indian pharmaceutical industry innovative transformation elevates it as an optimal investee. ${ }^{643}$ India offers advanced manufacturing process, ${ }^{644}$ a large market size to absorb the products ${ }^{645}$ and a low cost innovative skilled workforce. ${ }^{646}$ India holds the largest number of the Food and Drug Administration of the United States'

\footnotetext{
${ }^{641}$ Ibid, 270.

${ }^{642}$ See Part II D India as a Cae Study.

${ }^{643}$ See Chataway, Tait and Wield, above n 107, 698 - 699. See also Chaturvedi, Chataway and Wield, above n 10, 565, 565 .

${ }^{644}$ See generally Rai, above n 391, 405.

${ }^{645}$ See generally Kamlesh Gakhar Foreign Direct Investment in India 1947 to 2007 Policies, Trends and Outlook (New Century Publications, New Delhi, 2006) 48

${ }^{646}$ Ibid, 16, 49. See also R\&D Spreads Out www.fdimagazine.com (accessed 23 January 2009).
} 
approved manufacturing facilities compared to any other developing country, ${ }^{647}$ a fact which, of course, encourages Western pharmaceutical and medical firms' willingness to invest in India and collaborate with the local industry. From every angle India has the right characteristics needed to attract foreign direct investment to its pharmaceutical industry, and benefit from the investment, to fulfil the end of an enlarged innovative pharmaceutical industry.

Another theory was also raised in Kumar Rai's note which deals with the linkage between foreign direct investment and a host country's "market imperfection". ${ }^{648}$ According to the "market imperfection" theory, strong intellectual property rights alone will not attract foreign direct investment to countries which have what is called "healthy industries". ${ }^{649}$ In other words, the chances that Western firms invest in an imperfect industries are more likely than that they will invest in stronger economically industries, healthy economically industries. Once implementing this theory on the pharmaceutical industry, the theory seems to be very logical. The weaker economic position the Western pharmaceutical industry is in today suggests that in order to survive and to reduce the capital invested in the research and development process, it needs to collaborate with industries which will not demand much compensation for various services. What place is better to reduce the research and manufacturing costs but in developing countries which are on their way to consolidation and which rely on Western investment?

Reviewing the latter theory, India seems to be the right target for foreign direct investment from this perspective as well. India is still a developing country which is on its way of emergence, regardless of its newly industrialisation nature. It does not have the most optimal economy and gross domestic products rates and it still needs Western investment in its markets.

Moreover, it is clear that despite the evolvement of India's pharmaceutical industry, it still lacks the advanced research and development skills to conduct pharmaceutical innovation on high quantities. If it had, it would not need to rely on

\footnotetext{
${ }^{647}$ See Rai, above n 391, 404, 406. See also Lanjouw, above n 121, 16.

${ }^{648}$ Rai, above n 391, 409.

${ }^{649}$ Ibid.
} 
pharmaceutical multinationals for its evolvement. For this fact, the lagging behind Indian pharmaceutical industry, cannot demand the same services rates as the developed world does. ${ }^{650}$ Hiring an Indian pharmaceutical firm to conduct research of a drug will cost substantially less than hiring a pharmaceutical firm in France for example. Hence, India's imperfect market and its unhealthy pharmaceutical industry answer the latter theory and strengthen the linkage between India and foreign direct investment as a mutual source of benefits.

The given examination can testify of the potential the Indian pharmaceutical industry has to benefit from foreign direct investment in the industry. India has become an attractive place for outsourcing given its quality discovery, research, manufacturing and marketing. ${ }^{651}$ First to be noted is Pfizer, ${ }^{652}$ a North American pharmaceutical firm investment in the Indian pharmaceutical industry. Pfizer chose to outsource the manufacturing process of its drugs volume to 20 different Indian firms. ${ }^{653} 20$ different Indian firms are now exposed to Pfizer's advanced technology and sophisticated innovative products. ${ }^{654}$ From these 20 firms can potentially come 20 different scientists who would wish to take a part in the new growing pharmaceutical industry in India, open their own firms and impact on the local market with larger competition. As Pfizer, Merck, ${ }^{655}$ another North American pharmaceutical firm, outsourced 35 per cent of its manufacturing work to the Indian industry ${ }^{656}$ and opened similar possibilities to the local Indian marketplace.

One of the leading pharmaceutical firms in the Indian industry, Ranbaxy, ${ }^{657}$ changed its policy in regard to licensing, acquisitions and partnerships with multinational entities to a more accommodating one. Ranbaxy which mostly produces generics (although it has made a substantial progress in incremental innovation) is aware of the importance of collaborating with multinational pharmaceutical firms to

\footnotetext{
${ }^{650}$ Ibid.

${ }^{651}$ See generally Rao, above n 513, 107.

${ }^{652}$ See Pfizer www.pfizer.com/home/ (accessed 31 January 2009).

${ }^{653}$ See generally Katherine C Linton, Nicholas Corrado "A "Calibrated Approach": Pharmaceutical FDI and Evolution of the Patent Law in India" (2007) 1, 12 www.papers.ssrn.com (accessed 31 January 2009).

${ }^{654}$ See Hindman, above n 325, 470.

${ }^{655}$ See Merck www.merck.com (accessed 31 January 2009).

${ }^{656}$ See Linton, Corrado, above n 653, 12.

${ }^{657}$ See Ranbaxy www.ranbaxy.com (accessed 31 January 2009).
} 
acquire a more sophisticated technology to expand its innovative net and enlarge its relatively small capital available for research and development. ${ }^{658}$ Ranbaxy is aware of its limitations and at the same time of the prospect of advancement by collaborating with foreign pharmaceutical firms from the developed world. As Ranbaxy, Sun pharmaceutical industries Ltd, ${ }^{659}$ Lupin Ltd $^{660}$ and Zyduscadila, ${ }^{661}$ also Indian pharmaceutical and health care firms, expanded their marketing through partnerships, joint ventures and alliances with pharmaceutical multinational entities, ${ }^{662}$ to fulfill research and development orientation by $2020 .{ }^{663}$

The collaboration between the Indian firm Tata Consultancy Services (TCS) and the United States firm Eli Lilly(Lilly) ${ }^{664}$ to recruit TCS to conduct "clinical trial data management, statistical analysis and medical writing" 665 is another example of how foreign-local collaboration can educate the local Indian pharmaceutical industry and drive it to engage more in pharmaceutical innovation and not only in generics. In a recent study, it was revealed that Lily has over 17 small to large clinical research projects Ii 40 different hospitals across India, as for GlaxoSmithKlin (GSK) ${ }^{666}$ has started seven clinical trials of vaccines and drugs in India. ${ }^{667}$ NPIL, another Indian pharmaceutical firm incorporated with Lilly to conduct Lilly's "clinical development program, including investigational drug applications and human clinical trials". ${ }^{668}$ As the previous example of TCS, NPIL has most likely benefited from the exposure to Lilly's advanced technologies and developments.

The Indian firm GVK Biosciences ${ }^{669}$ contracted with the American pharmaceutical firm Wyeth to set up a research and development centre in Hyderabad (India) and work on Wyeth's projects. This example shows how foreign investment in

\footnotetext{
${ }^{658}$ See generally Chaturvedi, Chataway and Wield, above n 10, 584.

${ }^{659}$ See Sun pharmaceutical Industries Ltd www.sunpharma.com (accessed 31 January 2009).

${ }^{660}$ See Lupin www.lupinworld.com (accessed 31 January 2009).

${ }^{661}$ See Zyduscadila www.zyduscadila.com (accessed 31 January 2009).

${ }^{662}$ See generally Chaturvedi, Chataway and Wield, above n 10, 580.

${ }^{663}$ See Zyduscadila for example aim to achieve US\$3 billion sales by 2015 and completely change its platform of services to research and development. See Zyduscadila www.zyduscadila.com (accessed 29 August 2009).

${ }^{664}$ See Eli Lilly www.lilly.com (accessed 31 January 2009).

${ }^{665}$ Linton, Corrado, above n 653, 11.

${ }^{666}$ See GlaxoSmithKlin www.gsk.com (accessed 31 January 2009).

${ }^{667}$ Chaturvedi, Chataway and Wield, above n 10, 582.

${ }^{668}$ Linton, Corrado, above n 653, 11.

${ }^{669}$ See GVK Biosciences Inc www.gvkbio.com (accessed 31 January 2009).
} 
the industry has the potential to enlarge Indian research and development innovative skills and capacity to be enforced in future independent researching. ${ }^{670}$ As Wyeth, the American pharmaceutical firm Bristol-Myers Squibb (BMS) ${ }^{671}$ has contracted with the Indian firm Biocon to establish new research facilities in India ${ }^{672}$ and also contributed to the future success of Indian innovative pharmaceutical industry and the future success of better health care in India.

Acquiring Western firms is another way to benefit from Western technologies and research and development skills as understood by the Indian pharmaceutical firms NPIL and Sun pharmaceutical industries Ltd. ${ }^{673}$ Licensing out Indian products to Western firms was another way. ${ }^{674}$ Although there is a documentation of the success Indian firms have achieved from licensing out their products to Western firms, they often suffered from a set back. ${ }^{675}$ Indian firms have come to the understanding that pharmaceutical multinationals do not wish to develop in-licensed products for commercialisation for these products competed with their own innovated product. ${ }^{676}$ This was one of the wakening calls of the Indian pharmaceutical industry to develop their own products as Torrent learned from the poor experience it had with the Swiss pharmaceutical firm Novartis. ${ }^{677}$

The aforementioned examples show the immense benefits promised to India's pharmaceutical industry from foreign direct investment. Whether it is manufacturing, production or research contracts the Indian pharmaceutical industry is due to learn directly and indirectly from Western pharmaceutical entities and walk toward a new independent innovative industry. ${ }^{678}$ With advanced scientific capabilities and a solid economic platform, local firms will be driven to improve their performances, ${ }^{679}$

\footnotetext{
${ }^{670}$ See Linton, Corrado, above n 653, 11.

${ }^{671}$ See Bristol-Myers Squibb www.bms.com/pages/default (accessed 31 January 2009).

${ }^{672}$ See generally Linton, Corrado, above n 653, 11.

${ }^{673}$ Ibid, 14-15.

${ }^{674}$ See generally See Chaturvedi, Chataway and Wield, above n 10, 557.

${ }^{675}$ See generally Chaudhuri, above n 176, 8.

676 Ibid.

677 Ibid.

${ }^{678}$ See UNCTAD-ICTSD "Encouraging International Technology Transfer" (May 2004) Issue Paper No 7 ii, 14.

${ }^{679}$ See Adamou, Sasidharan, above n 517, 7 .See also Aditi K R Bajaj, Swastik Nigam "Globalization in the Indian Pharmaceutical Industry - FDI Spillovers and Implications on Domestic Productivity: 1991-2007" (2008) 1, 10 www.insightory.com (accessed 20 January 2009).
} 
advance their technological products, ${ }^{680}$ skills ${ }^{681}$ and knowhow technologies ${ }^{682}$ and in time the Indian pharmaceutical industry will be able to offer better health care to the local and foreign poorer population of the world through patent enforcement.

Although India has to clarify the vagueness and multiplicity of its foreign direct investment methods concerning the approval stages, as well as the uncertainty in its regulation requirements, ${ }^{683}$ it is likely to attract foreign direct investment to the pharmaceutical industry. However, the right economic-industry features alone, will not promise enough technology transfer without the promise of patent protection enforcement. Without property protection enforcement it seems that the alteration of the regulation of foreign direct investment will not benefit India with high technological inflows. Without assuring Western pharmaceutical multinationals that their products will not be threatened by extensive generic activity while collaborating with the local industry, they will not see India as the right investee.

Reviewing the potential of the Indian pharmaceutical industry to attract foreign direct investment inflows, and the direct potential to establish large competitive industry, leads to a discussion of the prime role patent plays to fulfil this end. In other words, the following part of the chapter reviews patent as a leading motivator of foreign direct investment in the pharmaceutical technology sector.

\section{B. Patent as a Leading Motivator of Foreign Direct Investment}

Patent enforcement can fulfil the end to intensify technology transfer to developing countries. Although India offers various benefits for pharmaceutical multinationals, without the promise of patent to their costly innovation, the prospect of local-foreign collaboration would not take place to the extent needed to enlarge the local industry innovative activity. ${ }^{684}$ Past experience already showed the direct link between knowledge inflows to patent protection in the host country. ${ }^{685}$ Since signing the TRIPS Agreement, India has enjoyed from growing partnering with

\footnotetext{
${ }^{680}$ See Hindman, above n 325, 478.

681 Ibid.

${ }^{682}$ See Bajaj, Nigam, above n 679.

${ }^{683}$ See Changes to Foreign Investment (2009) 28(4) International Financial Law Review.

${ }^{684}$ See Omer, above n 116, 558.

685 Ibid.
} 
pharmaceutical multinationals entities, licensing and joint ventures. ${ }^{686}$ The proper conclusion need to be taken is therefore of the strong connection between a host country's treatment towards patent protection of pharmaceuticals and the technology inflows it will benefit from.

Designating the pharmaceutical industry in this regard from any other industry is crucial. Not all foreign direct investment is automatically related to strong enforcement of intellectual property right regimes. ${ }^{687}$ As shown, the immense reliance of the pharmaceutical industry on patent protection derives from the rather simple process of copying the invented products. Given India's boosting generic pharmaceuticals, copying drug is not much of a difficult task. Hence, it would be correct to conclude that without the alteration India has made to its Patent Act and the introduction of patent enforcement on pharmaceutical products, India would not have succeeded in enlarging its collaboration scope with pharmaceutical multinationals as it did. ${ }^{688}$

Statistics show that from the outset of India's adoption of the TRIPS Agreement, there was a growing increase of mergers and acquisitions between multinationals entities and Indian firms. ${ }^{689}$ Another supportive element to the direct relation between foreign direct investment and patent protection is the fact that there has been a significant increase of investment after 1999, when India first amended its 1970 Patent Act, towards a full compliancy with the TRIPS Agreement's provisions. ${ }^{690}$ When India was one year away from fully implementing the TRIPS Agreement's provision and introducing pharmaceutical product protection in 2004, it enjoyed an exceptionally high increase of foreign direct investment which shows the connection between patent and foreign direct investment specifically to the pharmaceutical industry. ${ }^{691}$

\footnotetext{
${ }^{686}$ See generally Hindman, above n 325, 477.

${ }^{687}$ See Maskus, above n 597, 465-466.

${ }^{688}$ Nevertheless as implied earlier, the exclusion of protection on pharmaceutical incremental innovation can risk further collaboration of Western pharmaceutical firms with the Indian industry.

${ }^{689}$ See generally Chadha, above n 264, 4 .

${ }^{690}$ Ibid.

${ }^{691}$ Ibid.
} 
Lippoldt and Park concluded decisively of the connection between foreign direct investment and intellectual property rights enforcement in the host country, as well as to the positive effect foreign direct investment has on the host country's growth. ${ }^{692}$ They especially stressed this outcome in regards to the pharmaceutical industry, ${ }^{693}$ which as explained, is highly exposed to copying and thus patent is as a compass to the multinationals entities investment direction. ${ }^{694}$ Merck for example, constantly justifies its decisions to collaborate with Indian firms, due to the new Indian patent regime. ${ }^{695}$ With intellectual property assets accounting for 40 per cent of the corporations in the United States and 33 per cent in Europe, there is no room for error. Intellectual property is one of a leading factor in multinationals entities' decisions where to invest, ${ }^{696}$ especially concerning the pharmaceutical industry.

Maskus, Saggi and Puttitanun determined similarly to Lippoldt that there is a strong patent - foreign direct investment link. ${ }^{697}$ They stressed that this truth is most relevant in the pharmaceutical industry. ${ }^{698}$ Smarzynska reached the same conclusion $^{699}$ as well as Lai. ${ }^{700}$ In two additional studies, one by Mensfield and one by Lee and Mensfield, ${ }^{701}$ the scholars found that intellectual property rights are most significant in attracting investment and in specific, in establishing more research and development facilities in the host country. ${ }^{702}$ Needless to say enlarging the research and development capacity in India would have a direct impact on the increased competition in the pharmaceutical industry, and thus on their prices and availability to the poorer population in the country. Hindman joins these findings with specific

\footnotetext{
${ }^{692}$ See Lippoldt, above n 517, 44, 50. See also OECD Trade Committee "The Impact of Trade Related Intellectual Property Rights on Trade and Foreign Direct Investment in Developing Countries" (28 May 2003) TD/TC/WP(2002)42/FINAL, 13-16.

${ }^{693}$ Ibid, 5, 15, 19.

${ }^{694}$ See Lippoldt, above n 517, 44, 53.

${ }^{695}$ See Linton, Corrado, above n 653, 12.

${ }^{696}$ See Hindman, above n 325, 478.

${ }^{697}$ See Maskus, Saggi and Puttitanun, above n 125, 272.

698 Ibid.

${ }^{699}$ See Beata K Smarzynska "Composition of Foreign Direct Investment and Protection of Intellectual Property Rights: Evidence from Transition Economies”(Yale University, 1999) 1,26.

${ }^{700}$ See Edwin Lai "International Intellectual Property Rights Protection and Rate of Propduct Innovation (1998) 55 (1) Journal of Development Economics 133,147-148.

${ }^{701}$ See World Bank Intellectual Property Protection, Foreign Direct Investment, and Technology Transfer: Discussion Paper (Washington DC, 1994). See also Lee Jeong-Yeon, Edwin Mansfield "Intellectual Property Protection and US Direct Investment" (1996) 78(2) Review of Economics and Statistics 181, 186.

${ }^{702}$ Ibid. See also Lippoldt, above n 517, 44, 53. See also Maskus, Saggi and Puttitanun, above n 125, 272.
} 
reference to India. ${ }^{703}$ In practice, in the post TRIPS Agreement settlement era, foreign pharmaceutical companies have returned to India, and until these days are forming research and developing facilities all across the country. ${ }^{704}$

Addressing the issue of the connection between the two factors of patent and foreign direct investment specifically in the Indian pharmaceutical industry, Kumar Rai detailed his supportive findings. Based on a survey answered by multinationals entities subsidiaries in the Indian pharmaceutical industry, large scale Indian firms, medium and small sized firms, Kumar Rai found a direct connection between the two factors. ${ }^{705}$ Although India does answer the OLI theory as Kumar Rai stated, ${ }^{706}$ he also stressed that without patent protection the Indian pharmaceutical industry would not have been succeeding in attracting foreign direct investment at all. ${ }^{707}$

Of course India's exceptionally large size places it on a more attractive platform of foreign direct investment; however without patent securing pharmaceutical multinationals highly costly innovation, firms would not wish to take India's offer of low cost quality services after all. ${ }^{708}$ The success of the Indian software industry due to enlarged foreign investment in reaction to a more solid intellectual property regime in India, also supports the promise patent can offer to the Indian pharmaceutical industry evolvement as Maskus suggested. ${ }^{709}$

The conclusion of patent as a strategy to develop the Indian innovative pharmaceutical industry through foreign direct investment is necessary. Thus the conclusion of patent enforcement as a constructive tool to enlarge the competition in

\footnotetext{
703 See Hindman, above n 325, 477.

${ }^{704}$ See generally Arvind Singhatiya "Impact of Product Patent on FDI in Indian Pharmaceutical Industry" http://ezinearticles.com (accessed 18 January 2009).

${ }^{705}$ See Rai, above n 391, 420.

${ }^{706}$ Ibid, 423.

${ }^{707}$ Ibid, 423- 425. See also Lippoldt, above n 106, 4,7-8. Lippoldt stressed that although intellectual property rights alone would not be enough to attract pharmaceutical foreign direct investment, they would be the "deal - breaker" if not enforced by the portentous recipients of foreign direct investment.

${ }^{708}$ See N N Mehrotra "Patents Act and Technological Self-Reliance: The Indian Pharmaceutical Industry" (1989) Economic and Political Weekly 1059.See also Maskus, Reichman, above n 120, 14 15, 35. But see Branstetter, above $\mathrm{n}$ 551, 316-319. Branstetter is not a big believer of strong intellectual property rights in developing countries as a mean to enhance local innovation. However he did acknowledged the fact that without a solid intellectual property rights regime there would not be any attraction of multinational entities to developing countries and they would not invest in their markets.

${ }^{709}$ See Maskus, Reichman, above n 120, 34.
} 
the marketplace is also necessary. In the short time of the Indian full patent regime enforcement (2005-2009), the local pharmaceutical industry benefited from knowledge inflows. The long term future promises even larger quantities of investment and higher prospects of evolvement. As long as the Indian pharmaceutical industry grow and develop, it would be able to practice more in innovation.

An extensive introduction of new Indian drugs to the marketplace, competing with foreign patented drugs, would eventually be able to bring to price reduction. Nevertheless, as mentioned by Omer, India also needs to put more resources on research and development and diversify its pharmaceutical innovation programs. ${ }^{710}$ India is now prepared more than ever to use patent as it should, ${ }^{711}$ not as a barrier to drugs but as a vehicle to drugs through local enlarged independent development. The Indian pharmaceutical industry is strong enough to rely on collaboration with multinational entities and to create an extensive local competition, one which would even penetrate to the international arena.

Heading for better opportunities for the pharmaceutical industry and in time for the local and foreign poorer population to access patented drugs, this is not the time to regress from enforcing patent protection for pharmaceutical products. As experience taught India as well as other developing countries, patent can accelerate knowledge inflows from the West and thus better the healthcare status in the country through advanced technologies. Thus it would be expected that the Indian Government would enforce a fuller protection of pharmaceutical innovation, one to include the core level of pharmaceutical innovation as well as the incremental.

The urgency in making the change is not to be dismissed, especially when other strong developing countries such as China, threaten the ability of India to attract high technology inflows to fulfil the notion of larger innovative Indian pharmaceutical industry. ${ }^{712}$ China's threat on the evolvement of the Indian pharmaceutical industry through foreign direct investment, threatens on India's ability to find a solution to the high priced patented drugs through patent. As the Indian pharmaceutical industry can

\footnotetext{
${ }^{710}$ See Omer, above n 116, 561.

${ }^{711}$ See Rao, above n 513,114.

712 See generally Lippoldt, above n 106, 4. Lippoldt emphasised China as a top destination of foreign direct invesmtnet in the recent years.
} 
benefit from foreign direct investment, to enlarge its pharmaceutical industry activity, so can other newly industrialised developing countries like China, Brazil and South Africa. ${ }^{713}$ India should not stay behind.

China for example, which has similar economic patterns and growth prospect to India's, ${ }^{714}$ if not larger, offers low cost services as well as more comprehensive patent protection over pharmaceuticals inclusive of the incremental innovation products. ${ }^{715}$ As can be expected, without protecting the leading level of innovation in the pharmaceutical technology field, the very core of a complex innovation, India will not be as successful in attracting foreign direct investment to the local pharmaceutical industry. India will not be able to form a low cost drugs' market alternative through patent. As patent enforcement is a key factor in attracting foreign direct investment in the pharmaceutical industry, denying protection from incremental modified drugs will not answer the needed technology inflows to enlarge the competition in the marketplace in India.

However, before finalising the importance of pharmaceutical incremental innovation or the importance of its patenting to encourage innovation, invite more investment and form an influential price reducing competition, the next section reviews the risks China imposes on India to accomplish this end. Unless India would realise the importance of patenting pharmaceutical incremental innovation, China may become a more lucrative investee than India and thus risk India's ability to establish the large pharmaceutical industry needed to form extensive competition in the local pharmaceutical marketplace.

\section{The Competition for Foreign Direct Investment: India and China rivalry}

Comparing China to India and examining the impact China has on India's ability to attract more foreign direct investment, is an essential comparison. Often these two countries are referred to as Asia's non-identical twins or "Chindia" to show the similar economic progression these two economic giants have achieved in the last two

\footnotetext{
${ }^{713}$ See generally Maskus, Reichman, above n 120, 34.

714 See Hindman, above n 325, 484. See also Todaro, Smith, above n 11, 193- 198.

${ }^{715}$ See Palit, Bhattacharya, above n 215, 85-86.
} 
decades. ${ }^{716}$ However, the two do differ in several aspects. India has not yet softened its taxation laws or its strict labour laws which impact on its ability to attract foreign direct investment as much as needed for its technological growth. ${ }^{717}$ Nevertheless, in comparison to China, India has a better financial banking system, openness to foreign banks, higher educated workforce in science and engineering ${ }^{718}$ with growing prospects. $^{719}$

Compared to China, India has some advantages in almost all sectors, political, social, property rights enforcement. ${ }^{720}$ India's legal system is much more advanced and more trustworthy. ${ }^{721}$ Additionally, the restrictions China forces on foreign recruitment, also emphasise the advantages India has over China. ${ }^{722}$ Nevertheless, China has succeeded in attracting more foreign direct investment which has risked the potential growth of the Indian market ${ }^{723}$ and in an analogy to the pharmaceutical industry, can risk the growth of this sector and the indirect result of lower cost patented drugs as suggested.

As Baker viewed, whether China's low cost power supply, higher rates of literacy or its manufacturing capacity, or even its third position as the largest market in the world, it attracts more foreign direct investment into its marketplace than India does. ${ }^{724}$ Maybe the willingness of the Chinese Government to offer better taxation conditions to foreign firms at the expense of the local firms put China in a better position to attract more foreign direct investment. ${ }^{725}$ In any case, the position China has been granted in the global market does affect India's market share in the United States and European markets generally, ${ }^{726}$ inclusive in respect to the pharmaceutical industry.

\footnotetext{
${ }^{716}$ Peter E Koveos, Linghui Tang "China and India: A Tale of Two Entrepreneurial Giants" (2007) 12(4) Journal of Development Entrepreneurship 377, 377.

${ }^{717}$ See generally Roberto Ippolito "Private Equity in China and India" (2007) 10(4) Journal of Private Equity 36, 37.

${ }^{718}$ Ibid.

${ }^{719}$ See Luna, above n 140, 39.

${ }^{720}$ See generally Ippolito, above n 717, 38 .

${ }^{721}$ Ibid, 40.

722 Ibid, 41.

${ }^{723}$ See generally Baker, above n 121, 420.

${ }^{724}$ Ibid.

725 Ibid.

${ }^{726}$ Ibid, 422.
} 
In the year 2004, pharmaceutical firms in China held 65 per cent of total sales in compared to 77 per cent in India. ${ }^{727}$ Although the two countries' pharmaceutical research and development capacity is weaker if compared to pharmaceutical multinationals, India still holds an advantage compared to China. ${ }^{728}$ Only a few firms in China are capable of research and development and as statistics show, Chinese pharmaceutical firms invest only 2 per cent in research and development in comparison to an average investment of 7.7 per cent by Indian firms. ${ }^{729}$ If Ranbaxy innovated and generic products are activated in the United States and European markets, Hisun, a Chinese pharmaceutical firm does not, in addition to the fact that it is not capable of innovative activity at all. ${ }^{730}$ Nevertheless, China does enjoy a comparative advantage to India in regard to biopharmaceutical which is based on biological substances instead of chemical, in addition to its market size, which may affect India's higher position. ${ }^{731}$

Moreover, as Palit concerned, India's poor protection of innovative pharmaceutical products can add further risks to its continuing partnering with pharmaceutical multinationals ${ }^{732}$ and respectively its growing capacity of research and development. ${ }^{733}$ Although China has altered its patent laws to answer its obligation to enforce the TRIPS Agreements provisions, its enforcement has been weak. ${ }^{734}$ However it still manages to attract more foreign direct investment than India, ${ }^{735}$ even in the pharmaceutical industry spectrum. ${ }^{736}$ One explanation can be China's growing improvement of its intellectual property rights enforcement ${ }^{737}$ and its 9 per cent annual economic growth. ${ }^{738}$

The weaker enforcement of intellectual property in China can be of an advantage to India to attract more foreign direct investment. India which is economically

\footnotetext{
${ }^{727}$ Rao, above n 513, 112.

728 Ibid.

729 Ibid.

${ }^{730}$ Ibid.

${ }^{731}$ Ibid.

${ }^{732}$ See Palit, Bhattacharya, above n 215, 84.

${ }^{733}$ Ibid.

734 Ibid, 85.

${ }^{735}$ See Hindman, above n 325, 488 .

${ }^{736}$ See Palit, Bhattacharya, above n 215, 85.

${ }^{737}$ See Hindman, above n 325, 489.

${ }^{738}$ See Todaro, Smith, above n 11, 193.
} 
compared to China as a rising economic force can use its relatively stronger intellectual property rights enforcement, ${ }^{739}$ its better spoken English, ${ }^{740}$ its better chemistry research skills ${ }^{741}$ to reduce the 9 per cent gap of foreign investment compared to China ${ }^{742}$ and in particular, in the pharmaceutical technology field. ${ }^{743}$ Once India will complete its patent protection transformation and enables patenting of pharmaceutical modified drugs, it will then be considered a much more attractive investee. $^{744}$

As a more attractive investee, the Indian pharmaceutical industry would grow, offer larger quantity of innovated based drugs and reduce the patented drug pricing. However, India's reluctance to make the needed changes and alteration to its Patent Act, as can be learned from the ruling in the Novartis $A G v$. Union of India, ${ }^{745}$ endangers its attractiveness for foreign direct investment by Western pharmaceutical multinationals. Hence, this reluctance may deny India to offer the suggested solution to high priced patented drugs, using different measures than generics.

The next chapter addresses the importance of India's alteration of its Patent Act to include incremental innovation in the scope of patent protection, as the final brick to its pharmaceutical powerhouse. In addition to the fact that offering protection of pharmaceutical incremental innovation will invite larger investment by pharmaceutical multinationals, the chapter reveals the prime role incremental drugs innovation has to enlarge the number of products in the marketplace and present the opportunity to offer high quantity Indian-innovative based drugs at a lower cost. The chapter also addresses the motivation patenting pharmaceutical incremental innovation of tropical diseases research as a complementary field to a comprehensive healthcare in India.

\footnotetext{
${ }^{739}$ See Hindman, above n 325, 490.

${ }^{740}$ See Palit, Bhattacharya, above n 215, 86.

${ }^{741}$ Ibid.

${ }^{742}$ See Ippolito, above n 717, 38 .

${ }^{743}$ See Palit, Bhattacharya, above n 215, 86.

${ }^{744}$ Ibid.

${ }^{745}$ See Novartis AG v Union of India and Others [2007] MDH W P No 24759/06 and W P No

24760/06 (HC Madras), R. Balasubramanian and Prabha Sridevan.
} 
VI PATENTING INCREMENTAL PHARMACEUTICAL INNOVATION AS THE FINAL STEP

While innovation of an entirely new chemical entity or new molecular entity drug is a rarity, ${ }^{746}$ incremental pharmaceutical innovation is the norm. ${ }^{747}$ It is actually the very core of pharmaceutical innovation. ${ }^{748}$ Following small and incremental innovative steps, the leap towards the next breakthrough drug, for cancer or HIV/AIDS for example, could be wide. ${ }^{749}$ Hence, the pharmaceutical industry finds great importance in protecting incremental innovation through patent as it does with concerns to new chemical entity drugs.

It cannot be said that this fact was not known to the Indian Parliament when it finalised the 2005 amendment to the Patent Act which hardens the terms of incremental innovation eligibility of patentability. On the contrary, the Indian Parliament was aware to the pharmaceutical industry reliance on incremental innovation. This can be learned from reviewing the Parliament discussions on the statutory resolution regarding passing of the Patents (Amendment) Bill $2005 .{ }^{750}$ The Parliament was aware that if incremental innovation substances would be eligible for patent protection, the local generic pharmaceuticals pool would be substantially narrowed as a result. The Indian Parliament tried to justify this enactment as a step needed to prevent the patenting of trivial modified drugs, which would have delayed the generic version introduction to the marketplace. This phenomenon is commonly known as 'evergreening' which is one of the pharmaceutical industry strategies to keep its superiority in local and foreign markets as long as possible. ${ }^{751}$

\footnotetext{
${ }^{746}$ See Wertheimer, Levy and O`Connor, above n 274, 110.

${ }^{747}$ Ibid.

748 Ibid.

${ }^{749}$ See Palit, Bhattacharya, above n 215, 83.

750 (24 March 2005) The Indian Parliament Lok Sabha XIV "Combined Discussion on the Statutory Resolution regarding disapproval of Patents (Amendment) Ordinace, 2004 (No7 of 2004) and passing of the Patents (Amendment) Bill, 2005 (Resolution negatived and Bill Passed)".

${ }^{751}$ See Shanti Kumar, Nitin Shukla and Tanushree Sangal "Evergreening of Patents and the Indian Patent Law" (2009) 1, 1 www.papers.ssrn.com (accessed 09 September 2009). See also Allesandra Arcuri, Rosa Castro "How Innovative Is Innovative Enough? Reflections on the Interpretation of Article 27 TRIPS from Novartis v Union of India" (2008 Inaugural Conference of the Society of International Economic Law, Geneva, 15-17 July 2008). See also Mark A Lemley, Kimberly A Moore "Ending Abuse of Patent Continuations" (2004) 84 BUL Rev 63, 81-83.
} 
The main concern of the Indian Government was to answer the local population growing need of better healthcare which can be answered through better drugs accessibility. No one can deny that generics enable better access to drugs through low cost. However, and as shown before, relying solely on generics will not bring the answer of better healthcare to India in the long term run or allow it to offer low cost patented drug market. Offering protection of pharmaceutical incremental innovation may be able to fulfil this end through the intensifying of Indian based product competition. Given that India, as Brazil and China, has reached to a point where it can enjoy the protection of patent and benefit from intellectual property rights, ${ }^{752}$ it needs to balance this interest with the interest of its growing population to access patented drugs. ${ }^{753}$ As Dreyfuss stressed, this balance can be reached by promoting the local pharmaceutical industry to engage with its feasible level of innovation. ${ }^{754}$ Incremental innovation as shown earlier in the frame of novel drug delivery system is of a feasible level of innovation by the local Indian pharmaceutical industry.

As a key form of pharmaceutical innovation, it can be concluded that patenting incremental innovation will also invite more foreign investment to the Indian pharmaceutical industry. Western pharmaceutical firms would be more drawn to invest in countries which offer patent enforcement on incremental modified drugs. It can be further suggested that given to the lower cost entailed in incremental innovation research and development, ${ }^{755}$ Indian firms which are able to engage in pharmaceutical incremental innovation would direct their research to answer local needs for drugs, not only foreign's. However, without the promise of patent, the industry is not likely to enlarge, innovative capable Indian firms would continue their research on "global diseases" and the prospect of offering low cost patented drug market and better healthcare prospect to the Indian population would not be formed as possible. Without local safe ground of patent, local firms would not be engaging with innovation to answer local needs.

\footnotetext{
${ }^{752}$ See Dreyfuss, above n 132, 11.

${ }^{753}$ Ibid.

754 Ibid.

${ }^{755}$ See John Z Lu, William S Comanor "Strategic Pricing of New Pharmaceuticals" (1998) 80 The Review of Economics and Statistics 108, 108.
} 
The support in a wider patent enforcement in India does not suggest that generics should be completely outlawed. Generics production at the end of the patent term protection is a major player in the competition arena which contributes to the reduction of drugs pricing. ${ }^{756}$ However, enlarging the generic production on the account of innovation, can risk the Indian population healthcare for the limitation it would place on its enlarged innovative capacity and as suggested earlier, prevent the utilisation of patent to offer drugs in low cost.

The first section of the chapter reviews the competitive edge pharmaceutical incremental innovation can introduce to the Indian marketplace, as well as the possibility to engage the local industry on research on tropical diseases. As shown earlier, pharmaceutical incremental innovation is a matter of modification of existing drugs. ${ }^{757}$ It can offer different therapeutic solutions to one health condition through different versions of safety, dosing, equivalency $y^{758}$ ones if patented, can enlarge the competition in the marketplace and potentially influence on patented drugs pricing. The more drugs available to treat one health condition, the lower the prices of the drugs would be. ${ }^{759}$ Nevertheless, the Indian Government does not seem to find any comfort in this prospect. It does not seem to be open to it.

The second section reviews both the legislator and the judicial inflexible perspective of patenting pharmaceuticals as a barrier of drugs accessibility, which can only be resolved through generics. This untrusting preposition of patenting pharmaceuticals not only implies of a non compatible scheme to the TRIPS Agreement, it also prevents the patentability of incremental innovation and with it the possibility to offer low cost patented drugs aside to low cost generics. Notwithstanding the potential contribution of patenting incremental pharmaceuticals to introduce a new era of low cost patented drugs, it will not be seen, not only in the long term. Thus, and in a case of an immediate need to access drugs, India is recommended to practice the different flexibilities exists in its Patent Act to enable legal generic production of patented drugs. One possibility is through the use of the

\footnotetext{
${ }^{756}$ See The Congress of the United States, above n 216.

${ }^{757}$ See Global Public Policy Issues, above n 278.

${ }^{758}$ Ibid.

${ }^{759}$ See Wertheimer, Levy and O'connor, above n 274, 108.
} 
Indian extensive mechanism of compulsory licensing as suggested in the third section of the chapter.

\section{A. Patenting Pharmaceutical Incremental Innovation - a Prospect of a Better}

\section{Healthcare}

\section{Price reducing competition}

As reviewed in details in the third chapter, incremental development can offer vary optional drugs to treat one health condition. It can offer better tolerability chances for patients and even a drug with fewer side effects compared to the original chemical form. ${ }^{760}$ Through multiple advanced ways to consume a drug, incremental drugs can be perceived as fitting to the different consumer individuals. Respectively with vary therapeutic options to treat one health condition, incremental innovation promises the establishment of larger and a competitive pharmaceutical marketplace, one if implemented in India would be able to offer low cost patented drugs. ${ }^{761}$ This truth lies on several levels.

As stated by Wertheimer, Levy and O'Connor "the availability of multiple medications within a class can be expected to increase competition on price among agents within the class. This is true for almost all goods and services, not just pharmaceuticals". ${ }^{762}$

India is no stranger to the process of incremental innovation. India's speciality in incremental innovation is given in the form of novel drug delivery system. ${ }^{763}$ This system offers new versions of original drugs with better administration, better chances of tolerability of the drug, with fewer side effects and respectively a wider range of therapeutic solution options. ${ }^{764}$ A study of the benefits of the novel drug delivery system showed that in addition to the economic benefits, the variety in therapeutic

\footnotetext{
${ }^{760}$ See Global Public Policy Issues, above n 278.

${ }^{761}$ See Wertheimer, Levy and O`Connor, above n 274, 77,108.

762 Ibid.

${ }^{763}$ See generally Chaudhuri, above n 176, 15. See also Dhar, Gopakumar above n 179, 43.

${ }^{764}$ See generally Global Public Policy Issues, above n 278.
} 
options to treat one health condition can reach to a large variety of patients and save the lives of tens of millions of people. ${ }^{765}$

The Indian pharmaceutical firm Ranbaxy showed substantial success in this level of innovation in the export market. ${ }^{766}$ Ranbaxy was able to improve the drug Ciprofloxacin, originally produced by the German pharmaceutical firm Bayer AG. ${ }^{767}$ Instead of three dosages per day formulation, Ranbaxy succeeded in formulating once a day option. Bayer AG which realised the importance of the change Ranbaxy made to the drug, entered into a licensing contract with Ranbaxy and in addition to a US\$10 million payment, Bayer AG paid US\$65 million to Ranbaxy Laboratories over a period of four years. ${ }^{768}$ Although the marketing rights were in the hands of Bayer AG, India did keep the marketing rights to distribute the drug locally and in countries of the former Soviet Union, where Ranbaxy Laboratories enjoyed from marketing rights. $^{769}$

The option to alter a drug's therapeutic profile in effectiveness, dosing schedules and delivery systems ${ }^{770}$ has also expanded the sub-sectors in the pharmaceutical technology field and expended it to biotechnology drugs and generics. ${ }^{771}$ With expanded therapeutic options to one disease, incremental innovation has the potential to offer an enlarged competitive edge in the practicing pharmaceutical industry which would be able to impact on drugs pricing. As Lu and Comanor found, greater volume of substitutive drugs of the originals, which can be the right phrase for incremental drug development, would stop manufacturers' tendency to increase the price of the original drugs and even lower them. ${ }^{772}$ In other words, if introduced in greater volume, modified patented drugs can impact through competition on the setting of drugs pricing. The larger competition there is in the market, the lower prices of the drugs would be to enable the innovator with market superiority.

\footnotetext{
${ }^{765}$ See generally Shamnad Basheer, T Prashant Reddy "The "Efficacy" of Indian Patent Law: Ironing Out the Creases in Section 3(d)" (2008) 5(2) Scripted 232, 261.

${ }^{766}$ See generally Dhar, Gopakumar, above n 179, 43.

${ }^{767}$ Ibid. See also Bayer www.bayer.com (accessed 11 October 2009).

${ }^{768}$ Dhar, Gopakumar above n 179, 43.

${ }^{769}$ Ibid.

${ }^{770}$ See generally Global Public Policy Issues, above n 278.

${ }^{771}$ See generally Dhar, Gopakumar, above n 179, 44.

772 See generally Lu, Comanor, above n 755, 108.
} 
Given the growing consumer market in India as noted in the second chapter, and the prospect of the growing volume of Indian pharmaceutical firms, the option for pharmaceutical firms to compete with each other in such an expended way has the potential to offer the local population a better prospect of drugs accessibility through patent. Needless to mention that the low production cost of the novel drug delivery system research and development process would initially offer the drug in low cost, even prior to the impact of the suggested extensive competition. ${ }^{773}$

However, the contemporary innovative activity in the Indian local industry, cannot yet promise this option. Although the Indian industry has developed during the years, it is still a relatively small innovative industry. The number of the Indian patented drugs in the United States market shows the small innovative activity, even in incremental innovation. In 2007 there were only 312 Indian pharmaceutical patents holdings in the patent office of the United States, ${ }^{774}$ which represented mostly by new development of generics, in compare to new chemical entity drugs or their incremental modification. ${ }^{775}$

This is to say that even the incremental innovation practice, which is the very basic core of innovation in the pharmaceutical technology field, is not much practiced by the Indian pharmaceutical industry. The fact that Ranbaxy, one of the top 10 pharmaceutical firms in India held the most of the aforementioned patents can imply of the little number of participants in the innovative activity within the Indian pharmaceutical industry. ${ }^{776}$ This is to show of the unprepared Indian pharmaceutical industry to offer low cost patented drugs through increased innovative activity, a status which can be remedy with growing foreign direct investment as suggested in the previous chapter. In this respect given the link between foreign direct investment and patent, especially in the pharmaceutical industry, it can be concluded therefore that without patenting pharmaceutical incremental innovation, such an investment would not be offered or such a solution of low cost patented drugs in India.

\footnotetext{
${ }^{773}$ See Chaturvedi, Chataway and Wield, above n 10, 582. See also Dhar, Gopakumar, above n 179, 43.

${ }^{774}$ Chaudhuri, above n 176, 16.

775 Ibid.

776 Ibid.
} 
In the absence of patent protection of pharmaceutical incremental innovation, it is unlikely that the Western industry would further invest and collaborate with Indian pharmaceutical firms and as a result, the prospect of evolvement and enlargement of the local industry to establish influential competition would diminish. Consequently, the prospect of offering low cost patented drugs as an additional option to low cost generic drugs would not be consolidated.

\section{Tropical diseases research}

A second avenue to the importance of patenting incremental innovation in India lies in its encouragement of the local industry engagement in research of local diseases. The lack of incremental innovation protection in India, not surprisingly pushes Indian pharmaceutical firms to find a safe harbour for their innovation in Western markets. In other words, under a larger risk of generics copying, Indian pharmaceutical firms which are equipped with innovative skills, tend to engage with innovative activity to find cures for "global diseases" and neglect the research on tropical diseases.

The Patent Act in the United States for example offers protection to whom that invents or discovers any new and useful process, machine, composition of matter, or any new and useful improvement substances. ${ }^{777}$ In Pfizer $v$ Apotex, the Court of Appeal held that the test of obviousness lies only on reasonable expectation of success in compare to guarantee ${ }^{778}$. Hence if incremental drug for example can suggest of an expected healing contribution, it can be patented in the United States market. ${ }^{779}$ Obviously under the flexible criteria of patentability in the United States, incremental drugs can be commonly patented. In another case, Aventis v Lupin, the Court of Appeal held that the patentability criteria of obviousness in a situation "where the prior art gives the reason or motivation to make the claimed compositions, creates a prima facie case of obviousness." ${ }^{, 780}$ The latter case also shows the inviting platform for the Indian pharmaceutical capable firms to conduct research and development in respect to "global diseases", for their incremental innovation would be

\footnotetext{
${ }^{777}$ See 35 USC s 101

${ }^{778}$ See Pfizer Inc v Apotex Inc (2007) 480 F 3d 1348, 1364 - 1365 (Fed Cir) en banc.

${ }^{779}$ Ibid. See also KSR International Co v Teleflex Inc et al (2007) 165 L Ed 705,721-723.

${ }^{780}$ See Aventis Pharma Deutschland Gmbh and King Pharmaceuticals v Lupin Ltd and Lupin Pharmaceuticals Inc (2007) 499 F 3d 1293, 1301 (Fed Cir).
} 
easily protected in the lucrative market of the United States. A necessary result would be the neglect of research on tropical diseases, a prime death cause in India.

The same methodology is being practiced in Europe as under the European patent regime, any development of a completely new medicine to modified drugs of known formulations can be patented. ${ }^{781}$ With such an inviting platform, it is not surprising why the Indian innovative products are channelled to answer Western health needs in comparison to local needs. Needless to say that if this course will not change, it is unlikely that the spectrum of tropical diseases characterised the developing world would be narrowed.

As stressed earlier, the neglected field of research tropical diseases by the Western pharmaceutical industry lives the responsibility to find cures to these diseases on developing countries. As long as the Indian Government would continue to exclude and harden the patentability criteria of pharmaceutical incremental innovation, it is unlikely that Western firms would see in the local industry as a potential investee. Accordingly, without the prospect of developing the research capacity, the Indian pharmaceutical industry would not have the needed tools to conduct an independent research and development of drugs to treat tropical diseases. The necessary conclusion is therefore that without enforcing wide patent protection on pharmaceutical innovation, the local healthcare prospectus would not improve.

Chaudhuri however does not see the economic benefits of patenting pharmaceutical products in India. He based his conclusion mainly on the economic aspect. Given that the Indian firms' prospect to return their investment in the process of research and development is higher in Western markets, ${ }^{782}$ Chaudhuri does not see what economic justifications there are to enforce patent protection on pharmaceutical products. ${ }^{783}$ In this respect, the promise of patent protection by the West will motivate local Indian firms to conduct research and development in both new chemical entity

\footnotetext{
${ }^{781}$ A report by the EU working Group on Pharmaceuticals and public health noted in its 28 March 2000 report to the High-level Committee on health for policies and Actions in the framework of the EU treaty of Amsterdam www.ec.europa.eu/health/ph_overview/Documents/ke02_en.pdf (30 October 2009)

${ }_{782}^{782}$ See generally Chaudhuri, above n 176, 5 .

${ }^{783}$ Ibid.
} 
drugs and incremental drugs. ${ }^{784}$ In other words, under this reality, the absence of local patent enforcement on product in India would not have made any difference. Regardless to the fact that Chaudhuri seems to neglect the spectrum of healthcare, his conclusion is not as accurate in the economic spectrum either.

India will not stay a developing country for all times. In practice India is a newly industrialised country nearing to a developed country. ${ }^{785}$ The Indian market is one of the most rapid growing markets in the world. ${ }^{786}$ Additionally as the dollar's value proved to be unstable, the future promised benefits may arrive from the local market more than the Westerns. ${ }^{787}$ India's growing economy and strong technological infrastructure promise the Indian marketplace to become a more lucrative market in the near future, ${ }^{788}$ which would be able to answer the need of the local industry to return its investment in the pharmaceutical research and development. ${ }^{789}$

Basheer and Reddy pointed at another explanation which can contradict the logic of Chaudhuri's view. According to the Indian Patent Act, incremental innovations have to answer additional factors so that pharmaceutical incremental innovation for example, can be eligible for patent protection. It can be said that the Act has enlarged the criteria of inventive step, much more than needed, or even allowed by the TRIPS Agreement. ${ }^{790}$ The main element in the Act in this respect is the enhanced efficacy modified incremental substances would have to show, as a prior examination of eligibility to patent. ${ }^{791}$ India is the only country to the World Trade Organisation which enforces such strict criteria of incremental innovation patentability. ${ }^{792}$

As the authors pointed out, without an international harmonised patent protection scope, there is a possibility that countries would take the same measures towards

\footnotetext{
${ }^{784}$ Ibid. See also Branstetter, above n 551, 312.

${ }^{785}$ See Part II D India as a Case Study.

${ }^{786}$ See Gautam Kumara, Plalash Mitra and Chandrika Pasricha " 2015: Unlocking the Potential of the Indian Pharmaceuticals Market" (2007) 9, 11 www.mckinsey.com (accessed 17 October 2009).

${ }^{787}$ See Basheer, Reddy, above n 765, 265.

${ }^{788}$ Ibid.

${ }^{789}$ See Part II D India as a Case Study.

${ }^{790}$ See Part VI B 3 Implications on the international spectrum: the compatibility with the TRIPS Agreement.

${ }^{791}$ See The Patents (Amendment) Act 2005 (India), s 3(d).

${ }^{792}$ See generally Rai, above n 458, 45.
} 
Indian pharmaceutical innovation and exclude them from patent protection. ${ }^{793}$ This scenario would diminish any chance for the Indian industry to recoup its investment in richer foreign markets. There is a chance that if India continues with this route, Western pharmaceutical firms would despair from its weaker pharmaceutical patenting regime and leave the local industry with its innovative paralysis, without collaborating with local pharmaceutical firms. Under this scenario, it is doubtful that the Indian pharmaceutical industry would advance enough to offer better prospect of drugs accessibility to the local and foreign population through patent enforcement.

Pharmaceutical incremental innovation is of great benefit for the local population and the foreign poorer population. It offers vast therapeutic options to treat one disease. It can offer different dosing, versions with better safety merits and versions of drugs with fewer side effects. Clearly it enlarges the possibilities in the market and has the potential to increase the competition immensely. It only needs to be encouraged in India. However, without offering patent enforcement of pharmaceutical incremental innovation, generics would be the only low cost drugs available in the market.

Without patenting pharmaceutical incremental innovation, Western pharmaceutical firms would not invest in the local market, the local industry would not progress, it would not enlarge and the concept of offering low cost patented drugs would stay only an unfounded notion, as well as an activated industry in research of tropical diseases.

While the benefits of patenting incremental innovation is clear, it is still of great importance to question the Indian Parliament rational in placing rigid criteria of patent eligibility on incremental innovation. In this respect the next part of the chapter examines the conflict between evergreening and incremental innovation, together with the Indian legislator and judicator poor attempts to balance between the two which results with the un-patentable incremental pharmaceutical innovation. Respectively the implications of the compliance of the Indian Patent Act to the TRIPS

\footnotetext{
${ }^{793}$ See Basheer, Reddy, above n 765, 265. See also B Pazderka, K Stegemann "Pharmaceutical Innovation as a Collective Action Problem: An Application of the Economic Theory of Alliances" (2005) 8(2) Journal of World Intellectual Property 157, 170.
} 
Agreement are another mandatory analysis the next part of the chapter reviews. Only after further observations of these matters, one can finalise the legitimacy and the necessity of the Indian patentability mechanism of incremental innovation and the impact it has on the emergence of low cost patented drug market in India.

\section{B. The Paralysed Indian Pharmaceutical Patent Mechanism}

\section{The paralysing fear of evergreening}

Although incremental innovation promises extensive therapeutic advances and can lead to the next breakthrough drug, it is its minor form India fears from. Seeking to extend market exclusivity under low investment, at the end of the patent term protection on a drug, the pharmaceutical industry tends to ask for second and third patent protection on trivial modification versions of the original drug. ${ }^{794}$ This phenomenon is what commonly known as "evergreening". ${ }^{795}$ Evergreening a drug can cover new uses of the original drug or new chemical forms derived from the original drug, manufacturing processes and even colour. ${ }^{796}$

Modifying or changing a drug's patterns minimally is a level of innovation India wishes to exclude from protection as many other countries do. India does not want to grant the original inventor an additional 20 years of market exclusivity on almost the same drug as the original and delay the entree of the generic version. In contrast to incremental innovation which has an important scientific and therapeutic contribution to the public health as detailed, the triviality of evergreening means that it does not. ${ }^{797}$ In respect to the importance of abolishing protection from this minor level of innovation, the Indian Government had enforced rigorous terms of incremental innovation patentability in Section 3(d) to the Patent Act. ${ }^{798}$

\footnotetext{
${ }^{794}$ See generally Lemley, Moore, above n 751, 63, 81-83. See also See Kumar, Shukla and Sangal, above $\mathrm{n} 751$.

${ }^{795}$ See generally Kumar, Shukla and Sangal, above n 751. See also Arcuri, Castro, above n 751, 21.

${ }^{796}$ See generally Kumar, Shukla and Sangal, above n 751.

797 See Shamand Basheer "Limiting the Scope of Pharmaceutical Patents and Micro-Organisms: A TRIPS compatibility Review" (Oxford Intellectual Property Research Centre (OIPRC) University of Oxford, 2005) 2, 40.

${ }^{798}$ See The Patents (Amendment) Act 2005 (India), s 3(d)

3. What are not inventions

"The following are not inventions within the meaning of this Act, a-c)...

d) the mere discovery of a new form of a known substance which does not result in the enhancement of the known efficacy of that substance or the mere discovery of any new property or new use for a
} 
According to the Act, if a new form of an existing known substance, which can be a derivative of an existing drug, cannot show enhanced efficacy, it will not be eligible for patent protection. Even new uses of a drug, according to the Act, cannot be patented if it cannot answer the aforementioned criterion. ${ }^{799}$ In respect to incremental innovation, often pharmaceutical incremental innovation cannot show an enhance efficacy as demanded by the Act, but still hold colossal therapeutic merits which need to be encourage through patent protection enforcement. However, under the Indian Act, the latter will not necessarily be eligible for protection and as a result, would not be introduced to the Indian marketplace.

One cannot avoid asking whether there is a real necessity in preventing evergreening. Although patenting evergreened drug can delay the introduction of its generic form, it does not prevent the generic production of the original drug, which is more important for use than the secondary trivially changed drug. ${ }^{800}$ It is worthwhile to stress that patenting a new form of a drug, the "second" drug, does not revive the patent protection of the "first" drug. ${ }^{801}$ Thus generic firms would be able to access the first drug, copy it and sell it in low cost. ${ }^{802}$ However, the fear from evergreening is not completely baseless. Evergreening can modify a drug and introduce new form which is needed in low cost. It can also encourage a behaviour of misuse or mischievous of the exclusivity right promised to the patentee and prevents the local industry control over its own marketplace and the enjoyment of productive products in the marketplace. Clearly the latter scenario transgresses the core purpose of patent enforcement to encourage useful technoliges introduction to the protecting marketplace.

\footnotetext{
known substance or of the mere use of a known process, machine or apparatus unless such known process results in a new product or employs at least one new reactant.

Explanation.-For the purposes of this clause, salts, esters, ethers, polymorphs, metabolites, pure form, particle size, isomers, mixtures of isomers, complexes, combinations and other derivatives of known substance shall be considered to be the same substance, unless they differ significantly in properties with regard to efficacy"

${ }^{799}$ This methodology is similar to the prior patent scheme in New Zealand which ordered that new uses of known pharmaceutical compounds were not eligible for patent protection. In respect to the prior practice see Wellcome Foundation Ltd v Commissioner of Patents [1983] NZLR 385, 391(CA). At present new therapeutic uses of known pharmaceutical compositions are eligible for patnet protection. A summary of the current practice can be found in Pharmaceutical Management Agency $v$

Commissioner of Patents [2000] 2 NZLR 529, para 52.

${ }^{800}$ See Dean, above n 82, 730 .

${ }^{801}$ Ibid.

${ }^{802}$ Ibid.
} 
The essence of patent protection as part of the large scope of intellectual property rights is to encourage beneficial innovations for society and in regards to pharmaceuticals, to encourage therapeutically productive drugs innovation for the public domain. ${ }^{803}$ Granting pharmaceutical firms with patent protection for minimal developed drugs does not answer patent's enforcement agenda. ${ }^{804}$ With low standard of patentability, pharmaceutical firms would not have to invest much in research and development in order to enjoy from a promised income. In this respect pharmaceutical firms will not be motivated to make much effort to invent therapeutically beneficial drugs. They will gain their market exclusivity regardless. ${ }^{805}$

However, although the prevention of evergreening is a common goal for all countries, only India uses extensive measures to prevent this phenomenon. Unless the secondary derivative drug would be significantly more efficient therapeutically, the drug would not be eligible for patent protection. However, in practice, pharmaceutical incremental innovation cannot answer the Indian Patents Act demand of therapeutic efficacy. ${ }^{806}$ Although under the mechanism introduced by Section 3(d) India succeeds in preventing the patenting of evergreened drugs, it also succeeds to prevent the patenting of therapeutically important incremental innovated drug which can deter the notion of low cost patented drugs as suggested.

It can be clearly seen from the extreme measure the Indian Parliament took that excluding evergreening was not of a first priority to India. Firstly, evergreened drugs would not have caused barriers to access drugs for the possibility to generically produce their original forms (although it would have reduced the motivation to innovate more complex drugs). Secondly, Section 3(d) amendment was not really a case of necessity given to the enhanced economic and technological criteria terms exists in the Indian Patents Act to strain the eligible pharmaceutical innovation for patent protection. According to the Act, unless an invention shows technical

\footnotetext{
${ }^{803}$ See generally Arcuri, Castro, above n 751, 20.

${ }^{804}$ Ibid.

${ }^{805}$ Ibid. Nevertheless, one can claim that regardless to the low standard of patentability, pharmaceutical firms would still be motivated to put more effort in research and development for they would aspire to invent a much more lucrative innovation which would allow them to ask higher prices for the patent licesne.

${ }^{806}$ See Part VI B 2 The un- patentable incremental pharmaceutical innovation.
} 
advancement and significant economic contribution to the market, it will not be considered as answering the criteria of inventive step. ${ }^{807}$

Hence, through the justification of evergreening, India's Government has narrowed the patentability of large share of pharmaceutical innovation to enable large share of generic production. India's Government made its choice. However, it can be said that it was not an optimal choice from all angles for it excluded pharmaceutical incremental innovation from patent protection, together with the promise of forming low cost patented drug marketplace in India.

Nevertheless, there is a need to differentiate between incremental developments which hold therapeutic promises to the sick, to an evergreened drug which does not. ${ }^{808}$ However a proper differentiation would not be one which excludes the protection of incremental innovation for it will hinder the prospect of Indian innovative pharmaceutical industry evolvement. The full reliance on generics as the ultimate route to access drugs, nonetheless, brought the Indian Parliament to adopt this exact measure and the Indian courts to rely on health care considerations as prime considerations to allow a rights' holder to enjoy from full exclusivity position in the marketplace. Needless to say that India's choice to narrow the scope of patentability, would not sketch it as the potential investee and further attract vast economical and political ramifications which may not contribute to the formation of low cost patented drug marketplace in India.

\section{The un- patentable incremental pharmaceutical innovation}

(a) The legislative framework

The TRIPS Agreement opens with member countries' legislative autonomy in implementing the various obligations under its frame, ${ }^{809}$ in accordance to their health and social needs. ${ }^{810}$

\footnotetext{
${ }^{807}$ See The Patents (Amendment) Act 2005 (India), s 2(f)(ja).

${ }^{808}$ See Robert A Bohrer "Reach-Through Claims for Drug Target Patents: Rx for Pharmaceutical Policy" (2008) 26(1) Nature Biotechnology 55, 55.

${ }^{809}$ See TRIPS Agreement, above n 1, art 1. Dreyfuss statted however that given to the rigid interpretation of the TRIPS Agreement provisions by the WTO panels, the freedom developing countries have to use their discresion, is of somewhat narrow. See Dreyfuss, above n 132, 1. ${ }^{810}$ See TRIPS Agreement, above n 1, art 7, 8.
} 
Article 7 states that the enforcement of the TRIPS Agreement provisions should be done "in a manner conducive to social and economic welfare..."

Article 8 states that "members may... adopt measures necessary to protect public health and nutrition and to promote the public interest in sectors of vital importance to their socio-economic and technological development..."

In respect to these measures, India used the freedom it had to define its own version of patentable subject matter as prescribed by Article 27(1) of the TRIPS Agreement: "...patents shall be available for any inventions, whether products or processes, in all fields of technology, provided that they are new, involve an inventive step and are capable of industrial application". ${ }^{811}$ Respectively, the relevant provisions in the Indian Patents Act are as follows:

\begin{tabular}{|l|l|}
\hline $\begin{array}{l}\text { "Pharmaceutical } \\
\text { substance" }\end{array}$ & "Any new entity involving one or more inventive steps"812 \\
\hline invention" & $\begin{array}{l}\text { "Any invention or technology which has not been anticipated by } \\
\text { publication in any document or used in the country or elsewhere } \\
\text { in the world before the date of filing of patent application with } \\
\text { complete specification"813 }\end{array}$ \\
\hline "Inventive step" & $\begin{array}{l}\text { "A feature of an invention that involves technical advance as } \\
\text { compared to the existing knowledge or having economic } \\
\text { significance or both and that makes the invention not obvious to } \\
\text { a person skilled in the art". }\end{array}$ \\
\hline
\end{tabular}

Given to the high standard of novelty, it is unlikely that an evergreened drug would be patentable. ${ }^{815}$ This truth is especially relevant given the lack of interpretation of "technical advance" and the "economic significance" criteria in the inventive step term. ${ }^{816}$ Once an incremental pharmaceutical substance is involved with technical advancement or economic significance, which is not obvious to a

\footnotetext{
${ }^{811}$ Ibid, art 27(1) emphasis added.

${ }^{812}$ See The Patents (Amendment) Act 2005 (India), s 2(ta).

${ }^{813} \mathrm{Ibid}, \mathrm{s} 2(\mathrm{~g})(1)$

${ }^{814}$ Ibid, s 2(f)(ja) emphasis added.

${ }^{815}$ See Rai, above n 458, 79.

${ }^{816}$ Ibid, 64. See also Dhar, Gopakumar, above n 179, 15.
} 
researcher in its field and was not used in India before the time of the patent application submission, it will be patentable. It seems that in accordance to the Indian criteria as given in the aforementioned provisions, an evergreened drug is not possible for patenting for it is not likely to answer either term from the aforementioned stated. $^{817}$

However, abolishing the phenomenon of evergreening was only the surface cover of the Indian Parliament. The prior consideration was to widen the generic production as much as possible by excluding the patenting of incremental pharmaceutical innovation. The Act achieved that exact purpose. It seems that the Indian Parliament did not want to leave loose ends and allow any modified drugs to enjoy exclusive standee in the marketplace, not for trivial modified drugs (evergreening) or for more sophisticated modified drug.

The true intent as can be concluded from reviewing the wording of Section 3(d) was to narrow reduce the patentable drugs pool in the marketplace and allow high production of generics. According to Section 3(d) the following inventions are not patentable:

\footnotetext{
The mere discovery of a new form of a known substance which does not result in the enhancement of the known efficacy of that substance or the mere discovery of any new property or new use for a known substance or of the mere use of a known process, machine or apparatus unless such known process results in a new product or employs at least one new reactant.

Explanation - For the purposes of this clause, salts, esters, ethers, polymorphs, metabolites, pure form, particle size, isomers, mixtures of isomers, complexes, combinations and other derivatives of known substance shall be considered to be the same substance, unless they differ significantly in properties with regard to efficacy.
}

In respect to pharmaceutical innovations, all new forms of a known substance, or a known chemical compound, which already enjoyed from patent protection, or new use or property of that substance will not be eligible for patent protection unless they show enhancement in their efficacy. The Section clearly intended to address mainly

\footnotetext{
${ }^{817}$ See Shamnad Basheer "India's Tryst with TRIPS: The Patents (Amendment) Act 2005" (2005) 1 The Indian Journal of Law and Technology 16, 22.
} 
pharmaceutical innovations for the specific use of chemical and bio-organisms substances as the basis form to examine incremental pharmaceutical innovation eligibility to patent protection. ${ }^{818}$ The use of these substances teaches of the discriminatory attitude the Indian Parliament took in respect to the pharmaceutical technology field which was even ratified by the Indian Court.

Another element which can prove of the Parliament discriminatory behaviour towards pharmaceutical innovations lies in the source the Indian Parliament used in the wording of Section 3(d). In the process of constructing Section 3(d), the Parliament used similar provisions to the European Directive dealing with a generic drug safety regulation, as in Article 10(2)(b): ${ }^{819}$

\begin{abstract}
A medicinal product which has the same qualitative and quantitative composition in active substances and the same pharmaceutical form as the reference medicinal product, and whose bioequivalence with the reference medicinal product has been demonstrated by appropriate bioavailability studies. The different salts, esters, ethers, isomers, mixtures of isomers, complexes or derivatives of an active substance shall be considered to be the same active substance, unless they differ significantly in properties with regard to safety and/or efficacy. In such cases, additional information providing proof of the safety and/or efficacy of the various salts, esters or derivatives of an authorised active substance must be supplied by the applicant.
\end{abstract}

This way, by using the generic regulatory test to externalise patent protection from incremental pharmaceutical innovation, the Indian Parliament has expended the potential of incremental modified drugs innovation for legal generic copying. This truth is mostly emphasised in the context of the Madras court in the case of Novartis $A G v$ Union of India ruling. ${ }^{820}$ In this case, the Madras court analysed whether Glivec, a drug for Leukaemia produced by the Swiss Pharmaceutical firm Novartis, answered the "efficacy" term worded in Section 3(d) of the Act. ${ }^{821}$

\footnotetext{
${ }^{818}$ See Rai, above n 458, 82.

${ }^{819}$ Directive 2004/27/EC of the European Parliament and of the Council of 31 March 2004 amending Directive 2001/83/EC on the Community Code Relating to Medicinal Products for Human Use [2004] OJ L 136/ 34, 10(2)(b) emphasis added.

${ }^{820}$ See Novartis AG v Union of India and Others, above n 746.

${ }^{821}$ Ibid, para 13.
} 
According to the Madras High Court, the term efficacy has to be interpreted as therapeutic efficacy. ${ }^{822}$ Hence, if a derivative of a patented substance would not show enhanced therapeutic efficacy compare to its original form, it will not be eligible for patent protection. ${ }^{823}$ Although a therapeutic analysis is due to drugs marketing regulatory test, as safety, the Madras court set it to be a direct part to the patentability criteria, sentencing many incremental chemical compounds and their derivatives to an automatic generic production and narrowing the scope of drugs eligibility for patent protection. ${ }^{824}$

Usually, in the pre-clinical trials stage, pharmaceutical firms do not have any statistics on the therapeutic efficacy of the chemical compound. At this stage a pharmaceutical firm only holds the chemical compound it assembled. ${ }^{825}$ The information on a chemical compound efficacy is usually revealed in Stage III of the clinical trials, while testing the drug on thousands of participants in the clinical trials. ${ }^{826}$ The fact that the invention is incremental, only adds to the uncertainty of its efficacy level in the point of applying for patent protection. ${ }^{827}$ Moreover incremental innovation does not always consist with significant therapeutic enhancement. It can offer better administrative routes, less side effects and even better bioavailability ${ }^{828}$ and answer the criteria of new and inventive step of the Indian definition. However, it may not answer to the extent proof of efficacy demanded by Section 3(d). ${ }^{829}$ Consequently, these criteria will automatically bring to the rejection of most incremental drugs' patent applications in India ${ }^{830}$ and as a result, enlarge the generic drugs pool and hinder patent enforcement.

Respectively following to this discussion, the necessary conclusion is that under Section 3(d) terms, the only patentable forms of innovation are new

\footnotetext{
822 Ibid.

${ }^{823}$ Ibid.

${ }^{824}$ See Basheer, above n 817, 25.

${ }^{825}$ See Part III A New Chemical Entities.

${ }^{826}$ See generally Basheer, Reddy, above n 765, 256.

${ }^{827}$ Ibid.

${ }^{828}$ See generally Wertheimer, Levy and O`Connor, above n 274, 80-81.

${ }^{829}$ See Basheer, above n 817, 25.

${ }^{830}$ See Basheer, Reddy, above n 765, 256.
} 
chemical/molecule entities. ${ }^{831}$ Only new chemical entities would be able to show such an efficacy in the time of applying for patent protection prior to the conduct of clinical trials. ${ }^{832}$ The strict criteria added to the Act, does not leave room for other interpretations: pharmaceutical incremental innovation would not be patented in India.

India is the only country to apply such strict criteria to examine an invention inventive step/non-obviousness to question the eligibility of incremental innovation as patentable. Under this reality, local Indian firms would not be motivated to innovate and introduce new therapeutic solutions to the population and most importantly, the Indian pharmaceutical industry would not invite foreign direct investment or trade, to establish larger innovative industry. ${ }^{833}$ Furthermore, Western firms would not wish to invest in the Indian pharmaceutical industry and consequently, the prospect of enlarging the Indian patented drugs market would only stay in theory as well as introducing low cost patented drugs to the poorer population.

Parenthetically, even the limitation the Section 3(d) has placed in the form of new uses is of some illogical rational to the Indian Parliament agenda to patent entirely new inventions as the new chemical entity drugs. As rightly stated by Basheer, if the Indian Parliament intention was to heighten the standard of obviousness, to weed out evergreened drugs, a new use for a new form is much more innovative than showing an increase efficacy of a known substance. ${ }^{834}$ Thus in order to ensure that only new drugs would be patentable as new chemical entity drugs, India had to exclude even pharmaceuticals with enhanced therapeutic efficacy. Only the latter option would have promised the largest group of generics production.

It is most important to take the needed measures to protect the local public health and promise better access to drugs. Health infrastructures are of a country's great foundation and it is one of the prime rights protected in the Indian Constitution. ${ }^{835}$

\footnotetext{
${ }^{831}$ See R A Mashelkar, Chairman, Director General Council of Scientific and Industrial Research Report of the Technical Expert Group on Patent Law Issues (Prepared for the Indian Government, 2009) [Mashelkar Report/Group]. For furrther review of the Mashelkar Report see part VI B 3 Implications on the international spectrum: the compatibility with the TRIPS Agreement.

${ }^{832}$ See Basheer, above n 817, 29. See also Basheer, Reddy, above n 765, 232.

${ }^{833}$ See Rai, above n 458, 81 .

${ }^{834}$ See Basheer, above n 817, 24-25.

${ }^{835}$ The Constitution of India, art 21.
} 
However, excluding new pharmaceutical innovation as incremental would not assist India to achieve this end in full. Yes generics can offer low cost drugs however, public health in the form of drugs accessibility, cannot be one of the patentability criterion as implemented indirectly by the Indian legislator and judicator. It would not allow the Indian Government to answer public need of better healthcare as patent enforcement can, through the encouragement of innovation.

As noted before, the judicial tribunal applies therapeutic meaning to the term "efficacy" in Section 3(d), ${ }^{836}$ which substantially hardens the possibility to patent pharmaceutical incremental innovation now that an incremental modified drug has to show significant healing chances. Moreover, the prioritisation of public interest to access drugs has also blurred the judicial tribunal from the significance of patenting pharmaceutical innovation. As shown next, whether an incremental drug answers the criteria of patent as detailed in the Indian Patents Act, the veto power to grant a right's holder the standee deserved in the market is to be resolved on the grounds of the public convenience to access drugs. Needless to say that in respect to the general low purchasing power in India thus interpretation would deny pharmaceutical firms from enjoying the rights of a patentee in India. Instead of using patent as a tool of ample commoditisation of incremental drugs as a way to reduce prices, the Indian Parliament chose the generic production alone.

The next section examines these measures as enforced by the Indian judicial tribunal in two leading cases, the Novartis $A G v$ Union of India ${ }^{837}$ and Roche v Cipla Ltd. ${ }^{838}$ The two cases exemplify the rigid potential result of Section's 3(d) rigid criteria to the fulfillment of a large Indian innovative pharmaceutical industry. In both of the cases, the courts denied the pharmaceutical firms Novartis and Roche to enjoy from a rightly deserved protection of patent and its enforcement due to strict interpretation of Section 3(d) and the obligation to supply low cost drugs to the public. Criticising this reality product, the next section shows the inability of pharmaceutical firms to enjoy from protection of their costly inventions in India and thus the potential inability of the Indian pharmaceutical industry to introduce Indian

\footnotetext{
${ }^{836}$ See Novartis AGv Union of India and Others, above $\mathrm{n} 746$.

837 Ibid.

${ }^{838}$ See Roche v Cipla Ltd (19 March 2008) ND HC I.A 642/2008 in CS (OS) 89/2008, Justice S Ravindra Bhat.
} 
low cost patented drugs, market under the remaining of Section 3 (d) in the India Patents Act.

(b) The judicial commentary

(i) Novartis AG v Union of India

In 1960 Nowel and Hungerford discovered a generic mutation of Chronic Myelogenaus Leukemia (CML) a form of cancer. ${ }^{839}$ A potential drug "Imatinib free base" ${ }^{840}$ was found in $1990 .{ }^{841}$ In 1993, Novartis a Swiss pharmaceutical firm ${ }^{842}$ filed a patent covering this discovery in various countries. ${ }^{843}$ After further research, Imatinib free base was converted to particular salt form "Imatinib mesylate". ${ }^{844}$ Eventually from the Imatinib mesylate" Novartis found a stable polymorphic (organism) form - "beta crystalline" which than became what is known as the Glivec/Gleevec drug. ${ }^{845}$ It can be understood that the Imatinib mesylate form was incrementally improved to "beta crystalline", a polymorphic form, which was the basis of the firms' patent application. Novartis claimed that the "beta crystalline" form of Imatinib mesylate is more effective than the Imatinib free base, for its better absorption in the blood (bioavailability). ${ }^{846}$

The drug's therapeutic contribution was immense and raised some praises on Glivec as the "wave of the future", ${ }^{847}$ or the "magic bullet" to fight CML. ${ }^{848}$ One patient even said: "one minute I was looking at death. The next I was looking at my whole life in front of me". ${ }^{849}$ No one could dispute over the therapeutic efficacy Glivec offered the world. To date, Novartis enjoys from protection of Glivec in

\footnotetext{
${ }^{839}$ See generally The Story of Gleevec www.innovation.org (accessed 08 November 2008).

${ }^{840}$ Free base is a common phrase in the chemical research spectrum and represent "[A] standalone basic form of an amine, usually an alkaloid natural product, as opposed to its water-soluble salt form". See Medical Dictionary Online www.thefreedictionary.com (accessed 13 October 2009).

${ }^{841}$ See generally The Story of Gleevec, above $\mathrm{n} 839$.

${ }^{842}$ See generally Novartis www.novartis.com (accessed 08 November 2008).

${ }^{843}$ See generally The Story of Gleevec, above $n 839$.

${ }^{844}$ Ibid.

${ }^{845}$ Ibid.

${ }^{846}$ Bioavailability is "[T] he proportion of a drug which reaches its site of pharmacological activity when introduced into the body; more loosely, that proportion of any substance so introduced which enters the circulation" See Oxford English Dictionary Online, http://dictionary.oed.com (accessed 2 February 2009).

${ }^{847}$ See generally The Story of Gleevec, above n 839.

${ }^{848}$ Ibid.

${ }^{849}$ Ibid.
} 
almost 40 countries. ${ }^{850}$ Given to the inability to apply for patent protection before 2005 in India, Novartis submitted its application on Glivec to the "mailbox" in India. ${ }^{851}$ Although the Indian Controller General granted Novartis with exclusive marketing rights over Glivec, generic firms counterfeited the drug. ${ }^{852}$ However, further tries by generic firms were stopped by the Madras court in the case of Novartis AGv Adarsh Pharma. ${ }^{853}$

Nevertheless, in another petition submitted by Novartis concerning Glivec, Novartis's exclusive marketing rights were taken away on the grounds that the drug was a life saving product and that given to its being an imported drug, and its high price, there was a risk that potential trade disruptions would minimise the distribution of the essential drug in India. ${ }^{854}$ In other words, the public interest and the public convenience to access the drug were of the concluding considerations of the Madras High Court to exclude the patentee's legal rights of market exclusivity. In another case, Intas Labs Pvt Ltd v Novartis AG, the Madras High Court set the importance of the public interest as one of the main consideration in the process of granting exclusive marketing rights to an innovator, especially when concerning the supply of a medicine such as CML. ${ }^{855}$

In respect to the patent application itself, in 2005, when the mailbox was opened, the Assistant Controller of Patents in India rejected Novartis's patent application. ${ }^{856}$ The main ground for the dismissal was based on the drug lacking novelty and significant enhanced efficacy as obliged in Section 3(d). ${ }^{857}$ The Assistant Controller

\footnotetext{
${ }^{850}$ See Glivec Patent Case in India: Fsct vs. Fiction www.novartis.com (accessed 8 November 2009).

${ }^{851}$ See generally Shamand Basheer, Prashant Reddy "Ducking" TRIPS in India: A Saga Involving Novartis and the Legality of Section 3(d)" (2008) 20 (2) National Law School of India Review, 132,133. Under the "mailbox" system, and until India had finalised its patent enforcement on pharmaceuticals in 2005, all patents application submitted to the "mailbox" which was opened in 2005. See Part IV B Generics Fall and Innovation Rise. See also TRIPS Agreement, above n 1, art 448.

${ }^{852}$ See generally Garde, above n 129, 17.

${ }^{853}$ See Novartis AG v Adarsh Pharma (28 April 2004) Mad HC O A NOs 13 to 17/ 2004 and A NOs 841 to 849, 1076 and 1218/2004 in C S NOs 5 to 9 of 2004, para 17 R Balasubramanian, J.

${ }^{854}$ Novartis AG v Mehar Pharma (23 December 2004) Bom HC Notice of Motion No 293 of 2004 in Suit No 261 of 2004, para 29 D K Deshmukh, J.

${ }^{855}$ See generally Garde, above n 129, 18.

${ }^{856}$ Patent Application 1602/MAS/98 Indian Controller General of Patents Designs and Trademarks (14 October 2005).

${ }^{857}$ Ibid.
} 
was not convinced that Glivec's 30 per cent improvement of bioavailability showed any significant efficacy as demanded by the Act. ${ }^{858}$

Novartis submitted its appeal on the Assistant Controller's decision to the Madras High Court. ${ }^{859}$ Novartis claimed that Section 3(d) was incompatible to the TRIPS Agreement and to Article 14 of the Indian Constitution which ordered of equality before the law. ${ }^{860}$ In respect to the compatibility of Section 3(d) to the TRIPS Agreement, the Madras High Court held that it had no jurisdiction to examine the Section compatibility to an international treaty. ${ }^{861}$ In regards to the constitutional aspect of Section 3(d), Novartis claimed that the Section violated the primary right of equality before the law of India as deterred in Article 14 of the Indian constitution. ${ }^{862}$ Novartis claimed that as Section 3(d) does not simplify what would be considered as "enhancement of known efficacy" or "differ significantly in properties with regard to efficacy", the Section is to be treated as unconstitutional as it is arbitrary. Further more, Novartis also based the latter claim on the grounds that Section 3(d) offers vast discretion to the patent office to decide what would be efficient or not. ${ }^{863}$

The Madras High Court denied Novartis's two claims in respect to Section's 3(d) compatibility to the Indian Constitution. The High Court held that the mere fact that a provision is arbitrary or vague cannot elevate it as unconstitutional. ${ }^{864}$ A statutory has to be examined in full on the basis of its background, and in respect to Section 3(d), the fact that it was worded to try to abolish the phenomenon of evergreening, cannot designate it as an arbitrary provision. ${ }^{865}$ Also by examining Section $3(\mathrm{~d})$ legislation background and the fact that its purpose was to abolish the phenomenon of evergreening, the High Court found that the Section cannot be considered as vague or arbitrary. ${ }^{866}$ As the High Court held, the prior order of Section 3(d) was to "provide easy access to the citizens of this country to life saving drugs and to discharge the

\footnotetext{
${ }^{858}$ Ibid.

${ }^{859}$ See Novartis AG v Union of India and Others, above n 745.

${ }^{860}$ Ibid, para 1-5.

${ }^{861}$ Ibid, para 8. Compare Basheer, Reddy, above n 766, 140.

${ }^{862}$ See The Constitution of India, art 14: "Equality before law - The State shall not deny to any person equality before the law or the equal protection of the laws within the territory of India."

${ }^{863}$ See Novartis AG v Union of India and Others, above n 745, para 10-11.

${ }^{864}$ Ibid, para 11,15 .

${ }^{865}$ Ibid, para 11-12.

${ }^{866}$ Ibid, para 13.
} 
constitutional obligation of providing good health care to its citizens". ${ }^{867}$ Clearly this sort of justifications of Section 3(d) cannot encourage innovation and introduce new technologies to the market. In other words, this sort of justifications would not allow an increased competition in the marketplace of patented incremental drugs.

In respect to the interpretation of the term "efficacy" in Section 3(d), the High Court applied a therapeutic meaning. Hence, a derivative form of a drug has to show significant healing prospectus of a disease and positive affect on the human body. ${ }^{868}$ The High Court did found that the Section interpretation referred to all fields of technology, however, it still based the right interpretation on a medical therapeutic contribution. ${ }^{869}$ The High Court did acknowledge that the purpose of the Section's wording lied in respect to pharmaceutical innovation. ${ }^{870}$ In other words, the High Court directly forced unsupportive interpretation to the patenting of pharmaceutical incremental innovation. Although incremental pharmaceutical innovation can offer vast therapeutic opportunities to the sick population, they do not always show significant efficacy as demanded by the Indian Act.

As shown before, in the stage of applying for patent, pharmaceutical firms do not hold vast information of the efficacy of a chemical compound. This information usually gathered at the post stage of clinical trials. Therefore, the demand from a pharmaceutical firm to show a chemical compound significant therapeutic efficacy as a preliminary term of patent eligibility cannot be answered. Consequently, lacking the possibility to enjoy from patent protection on their costly products, pharmaceutical multinationals would soon stop to perceive India as an uninviting investee of foreign direct investment, a reality which would directly impact on allocating a solution of low cost patented drug marketplace in India.

In light of the court decision, Novartis's claims were transferred to the Indian Intellectual Property Appellant Board. This organisation was set up to decide on

\footnotetext{
${ }^{867}$ Ibid, para 19.

${ }^{868}$ Ibid, para 13.

${ }^{869}$ See This interpretation was criticised by Basheer and Reddy, which raised the need to interpret the term "efficacy" based o a regular dictionary, in comparison to medical dictionary. See Basheer, Reddy, above n 765, 244.

${ }^{870}$ See Novartis AG v Union of India and Others, above n 745, para
} 
appeals submitted on intellectual property rights authorisation ruling across India. ${ }^{871}$ In a recent hearing in the case of Novartis $v$ The Union of India and others held by the Intellectual Property Appellant Board, the tribunal found that Novartis's appeal ought to be denied. ${ }^{872}$ Although the Appellant Board found that Glivec answered the terms of "new" "inventive step" and utilisation under the Indian Patents Act, ${ }^{873}$ it did not find that Glivec's increased blood absorption (bioavailability) of 30 per cent is as significant as demanded by Section 3(d) ${ }^{874}$ In accordance to the Intellectual Property Appellant Board, Novartis has brought its claims to the Supreme Court of India. ${ }^{875}$ At the time of submission of this thesis, there was not a decision made by the Indian Supreme Court.

Nevertheless, although a final decision was not yet given in respect to Novartis's application, the aforementioned tribunals' decisions, the Intellectual Property Appellant Board and the court show of the general approach India takes on the issue of patenting incremental innovated drugs. This approach does not imply of the future enlargement of the patented drug marketplace in India or the option to utilise patent enforcement as a tool to reduce drugs pricing.

Nevertheless, there is still room for a change. As India learned in the past it had to join the international community to enforce patent protection on pharmaceutical products, it may soon learn the importance of full compliancy enforcement, one which includes the patenting of pharmaceutical incremental innovation. India may waken to the possibilities patenting pharmaceutical incremental innovation as the drug Glivec, can offer to the public improved healthcare. India may waken to the importance of patenting the very core innovation in the pharmaceutical technology field as incremental to invite high inflows of foreign direct investment. India may waken to the possibility patenting incremental innovation can offer to the enlargement of the local competition to reduce drugs pricing. Only time will show if India will adopt the

\footnotetext{
${ }^{871}$ See Indian Intellectual Property Appellant Board www.ipab.it.nic.in (accessed 13 October 2009).

${ }^{872}$ See Novartis AG vUnion of India (26 June 2009) Intellectual Property Appellate Board M P Nos 1 to 5/2007 in TA/1 to 5/2007/PT/CH, M P No 33/2008 IN TA/1/2007/PT/CH, TA/1 TO 5/2007/ PT/CH, para 11.

${ }^{873}$ Ibid, para 10 (ii) - (iii).

${ }^{874}$ Ibid, para 10 (v).

${ }^{875}$ See Novaris Challenges Gleevec Patent Rejection in the Supreme Court www.lawyerscollective.org/node/1042 (14 October 2009). The aforementioned article offer attachement to the complete text of Novartis's Special Leave Petition.
} 
patent mechanism to offer better healthcare future for its population. Unfortunately India has not yet wakened to this possibility, as demonstrated in the recent case of Roche v Cipla. ${ }^{876}$

(ii) Roche v Cipla Ltd

F Hoffman - La Roche ${ }^{877}$, submitted a claim before the Delhi High Court against the Indian generic pharmaceutical firm Cipla for infringing Roche's patent on Erlotinib granted in $2007,{ }^{878}$ a drug for lung cancer called Tarceva by its marketing name. ${ }^{879}$ As Roche claimed Tarceva as a pioneer drug (in different from incremental), Cipla argued that Erlotinib was a derivative form of Quinazoline compound which was patented in three European countries back in 1993, which did not answer the provision under Section 3(d). ${ }^{880}$ Another form of arguments made by Cipla was related to the price of the drug. ${ }^{881}$ As Roche asked 4,800 Rs per tablet, ${ }^{882}$ which equal to US $\$ 103,{ }^{883}$ Cipla asked for 1,600 Rs for its generic version ${ }^{884}$ which is equal to US $\$ 34 .{ }^{885}$ Accepting Cipla's arguments, the interim injunction application submitted by Roche, was denied. ${ }^{886}$

Although the High Court found Tarceva to be innovative and non-obvious, ${ }^{887}$ The High Court accepted Cipla's argument and found that Roche was unsuccessful to show an enhanced efficacy of Tarceva (Erlotinib) in compare to the Quinazoline compound as demanded by Section 3(d). ${ }^{88}$ Although Dr Singhvi from Behalf Roche showed a substantial contribution and healing efficacy of Tarceva compared to the former substance its chemical compound relied on, ${ }^{889}$ and also showed an increase in

\footnotetext{
${ }^{876}$ See Roche v Cipla Ltd, above n 838.

${ }^{877}$ See Roche www.roche.com (accessed 14 October 2009).

${ }^{878}$ See Roche v Cipla Ltd, above n 838, para 1-3.

${ }^{879}$ Ibid, para 2.

${ }^{880}$ Ibid, para 7-13.

${ }^{881}$ Ibid, para 14.

${ }^{882}$ Ibid.

${ }^{883}$ See www.X-rates.com (accessed 16 October 2009).

${ }^{884}$ See Roche v Cipla Ltd, above n 838, para 14.

${ }^{885}$ See www.X-rates.com (accessed 16 October 2009).

${ }^{886}$ See Roche v Cipla Ltd, above n 838, para 87.

${ }^{887}$ Ibid, para 69.

${ }^{888}$ Ibid, para 36, 78.

${ }^{889}$ Ibid, para 27.
} 
life expectancy, ${ }^{890}$ the High Court found that Tarceva merits do not answer the criteria under Section 3(d). Respectively the High Court denied Roche's application. ${ }^{891}$

Although the High Court found that Tarceva did not answer the criteria of Section 3(d) as showed by Cipla, the High Court addressed another key aspect in the decision which as the High Court held, should lead the Indian judicator. This aspect included the public interest of low cost drugs and healthcare needs. As in the case of Novartis $v$ Union of India, the High Court in the given case of Roche $v$ Cipla, found that the aspect of patients' convenience to access a drug is of great importance, as other considerations as employment, public interest in the product and product quality. ${ }^{892}$ Price differential, especially in the case of a life saving drug, or even in a life improving drug, is a prime factor to guide the courts. In the discussed case, Roche did not have manufacturing facilities in India and Cipla was the only manufacturer of Tarceva in third of the cost as requested by Roche. ${ }^{893}$

The High Court did acknowledge India's obligation to the TRIPS Agreement. However, at the same time, it was stated that "the court cannot be unmindful of the right of the general public to access life saving drugs which are available and for which such access would be denied if the injunction was granted". ${ }^{894}$ The High Court held that promising drug accessibility is of a constitutional obligation which has to be assured. ${ }^{895}$ Article 21 of the Indian Constitution orders that "no person shall be deprived of his life or personal liberty to except according to procedure established by law". 896

The High Court held that "if the injunction in the case of life saving drugs were to be granted, the High Court would in effect be stifling Article 21 so far as those would have or could have access to Erloticip are concerned". ${ }^{897}$ Under these considerations, the New Delhi High Court found that the public interest of accessing drugs is of much

\footnotetext{
${ }^{890}$ Ibid, para 71.

${ }^{891}$ Ibid, para 87.

${ }^{892}$ Ibid, para 83.

${ }^{893}$ Ibid, para 84 .

${ }^{894}$ Ibid, para 85.

895 Ibid.

${ }^{896}$ See The Constitution of India.

${ }^{897}$ See Roche v Cipla Ltd, above n 838, para 85.
} 
more importance than the public interest of enforcing patent protection to encourage innovation and used this argument as an additional ground to dismiss Roche's petition for interim injunction against Cipla.

In respect to the aforementioned decision, Roche submitted an appeal to the Delhi High Court, which dismissed Roche's claims, and denied its appeal. ${ }^{898}$ As in the previous hearing, the New Delhi High Court in the appeal found that Roche had not shown Tarceva's enhanced efficacy as required by Section 3(d) and criticised the Controller of Patents by granting Roche's initial patent application. ${ }^{899}$ Furthermore, although the High Court acknowledged India's commitment to the TRIPS Agreement, it still found that the public interest of accessibility to drugs is a prime consideration in the case of interim relief. ${ }^{900}$

With respect to the High Courts' decisions, accessing drugs is of a priority importance at all times, however, if it will come at the expense of the innovator legal right, new needed drugs would not be introduced to the Indian marketplace. This given premise was proven times and times again. If continued to treat patent enforcement as a non-preferable case, it will not be long before the pharmaceutical industry in India would stop its trading relations with the West and the first to suffer from these ramifications would be the sick population. ${ }^{901}$

Finding a solution to the problem of high cost drugs through patent and encourage the innovative orientation of the Indian pharmaceutical industry cannot be achieved through intensified generic production. In other words, it cannot be achieved through the narrowing of the patent scope by excluding the very core innovative level in the pharmaceutical industry, the incremental innovation. Moreover, and as much as the importance of offering low cost drugs to the poor population is vital, this consideration cannot play a role in the matter of patents eligibility, as applied by the Indian courts in both the aforementioned cases. Not only did the courts dismiss some of great therapeutic importance of the two drugs, Glivec and Tarceva, it justified

\footnotetext{
${ }^{898}$ F Hoffmann-La Roche Ltd and ANR v Cipla Ltd (24 April 2009) FAO (OS) 188/2008, Justice S. Muralidhar.

${ }^{899}$ Ibid, para 68.

${ }^{900}$ Ibid, para $77-79$.

${ }^{901}$ See Rai, above n 458, 81.
} 
public convenience to access the drugs as key considerations in the decision of granting the interim relief. Clearly under this methodology, allocating vast Indian patented incremental drug competition would not realise.

Under the Indian Patent Act, once a pharmaceutical invention answers the criteria of new, inventive step and has industrialised application, it has to be protected through patent. However with the patent eligibility additional strainer in Section 3(d), a pharmaceutical incremental innovation cannot answer these terms. There were several aspects examined in respect to Section 3(d). It was proven that Section 3(d) is not necessary to prevent the phenomenon of evergreening. It was also shown that Section 3(d) rigid criteria can deny from the Indian pharmaceutical industry the progression it needs to establish low cost patented incremental drug marketplace through extensive competition. Nevertheless, an additional aspect to Section 3(d) is the matter of its compatibility to the TRIPS Agreement. The next part of the chapter asks of the legitimacy of Section 3(d) amendment to the TRIPS Agreement obligation not to discriminate against the patentability of any invention from any field of technology. ${ }^{902}$ Although the result has great importance to the aspect of Section 3 (d) legality and the Indian obligation fulfilment to the international community, the result does not change the fact that Section3 (d) is not compatible to the option of offering low cost drugs through patent enforcement.

3. Implications on the international spectrum: the compatibility with the TRIPS Agreement

The legislative framework of the TRIPS Agreement paints a very clear and explicit picture of the negotiators' intention. The aim was to eliminate any chance of "blanket exclusions" of certain technologies from patentability, especially within the pharmaceutical technology field, agrochemicals and food. ${ }^{903}$ In practice Article 27(1) introduced one main aspect that the Paris Convention dismissed: the definition of the eligibility of patent protection. ${ }^{904}$ Article $27(1)$ required that "patents shall be

\footnotetext{
${ }^{902}$ See TRIPS Agreement, above n 1, art 27(1).

${ }^{903}$ See Graeme B Dinwoodie, Rochelle Cooper Dreyfuss "WTO Disputes Resolution and the Preservation of the Public Domain of Science under International Law" in Keith E Maskus, Jerome H Reichman (eds) International Public Goods and Transfer of Technology Under Globalized Intellectual Property Regime (Cambridge University Press, New York, 2005), 866.

${ }^{904}$ See Rai, above n 458, 60.
} 
available and patent rights enjoyable without discrimination as to the place of invention, the field of technology and whether products are imported or locally produced". Clearly the terms of the Article are substantially broad and can imply of the initiators intention to include as many innovations in the patent scope, from any level and any field of technology, again if answered the given terms. ${ }^{905}$ Nevertheless, the TRIPS Agreement did enable countries to define the different terms in their legislation as they saw fit. ${ }^{906}$

Under this wide ranged definition, one can argue that the restrictions Section 3(d) has added to the "inventive step"/non-obviousness criteria, contradict Article 27 order of non-discriminatory. Given that under Section 3(d) only new chemical entity drugs are eligible for patent protection and the core pharmaceutical innovation is based on incremental, the necessary conclusion is of Section 3(d) discriminatory nature to the TRIPS Agreement. This can impact on the international community perspective towards India as a trustworthy partner and thus impact on India's capability to establish high patent-based drug competition in the marketplace.

The World Trade Organisation Dispute Settlement Body's Panel ruling in the case of the Canadian patent protection for pharmaceutical products, dealt with the question whether two exception to patent exclusivity rights in the Canadian Patent Act infringe Article 27(1) and 28(1) of the TRIPS Agreement. ${ }^{907}$ Under the Canadian Patent Act, Section 55.2(1) allowed to exclude the patentee's market exclusivity rights under the exception of research purposes. ${ }^{908}$ Section $55.2(2)$ allowed manufacture competitors to the patentee, to stockpile the patented products copies six months prior to the end of the patent term and sell it as soon as the patent term protection ends. ${ }^{909}$ Canada has relied on Article 30 of the TRIPS Agreement to justify these two measures, given that the Article allows countries to exclude the patentee's exclusive right in the

\footnotetext{
905 Ibid.

${ }^{906}$ See TRIPS Agreement, above n 1, 1.

${ }^{907}$ See Canada - Patent Protection for Pharmaceutical Products, Report of the Panel (17 March 2000) WT/DS114/R para 3.1(Panel, WTO). Articles 27 and 28 of the TRIPS Agreement define the terms of patent eligibility as well as the patenee's exclusive right in the market respectively. See TRIPS Agreement, above n 1, art 27, 28.

${ }_{908}$ Ibid, para 2.1. See also An Act respecting Patents of Invention RS C 1985 c P-4, s 55.2(1).

${ }^{909}$ See Canada - Patent Protection for Pharmaceutical Products, Report of the Panel, above n 907, para 2.1.
} 
marketplace as long as the exclusion does not conflict with the normal utilisation of the patent owner.

In practice, the panel did find that Article 55.2(2) contradicted the TRIPS Agreement. However, the main aspect in the Panel's decision which is of immense importance to the analysis of Section 3(d) compatibility to Article 27(1) of the TRIPS Agreement was the interpretation of the term 'discrimination'. The panel differentiated between two levels of discrimination: de jure and de facto. ${ }^{910}$ Given that Section 55.2(1) did not say that the exception is to be enforced in regards to pharmaceutical patenting in specific, it was not considered as de jure discriminating. The fact that the Article did not show any discriminative effect or purpose towards pharmaceutical patenting, brought the panel to conclude that it was not even de facto discriminatory to Article 27(1) of the TRIPS Agreement. ${ }^{911}$ In an analogy to Section 3(d) however, it can be concluded that Section 3(d) answers the two levels of discrimination, especially the de jure discrimination. The very use of chemical substances as well as micro-organisms as the basis substances to examine enhanced efficacy, teaches of a de jure discrimination of Section 3(d) to Article 27(1). ${ }^{912}$ The Parliament intention was to harden the patentability of pharmaceutical innovation and for that reason the aforementioned substances were specifically noted in the Explanation clause in Section 3(d). A different conclusion cannot be reached.

Another supportive fact of Section's 3(d) de jure discriminatory nature to Article $27(1)$ is that its wording is based on a generic drug safety regulatory. Another fact is the detailed Parliament discussions prior to the 2005 amendment which specifically raised concerns on the accessibility to drugs if other than new chemical entity drug would be patented. In other words concluding Section 3(d) as discriminatory to the TRIPS Agreement cannot be different as Dr R A Mashelkar found in the report on behalf of the Members of Technical Expert Group on Patent Law Issues submitted to the Indian Government. ${ }^{913}$

\footnotetext{
${ }^{910}$ Ibid, para 7.94, 7.98.

${ }^{911}$ Ibid, para 7.99-101.

912 See Rai, above n 458, 63. See also Basheer, above n 797, 37.

${ }^{913}$ See Mashelkar Report, above n 830. The initial report submitted in 2006, was later withdrew by the Mashelkar Group given to inaccuracy and plagiarism allegation. See Rai, above n 458, 44.
} 
Dr R A Mashelkar the chairman of the Members of Technical Expert Group on Patent Law Issues (Mashelkar Report/Group), appointed by Indian Government to answer the discriminative aspect of Section 3(d) to the TRIPS Agreement in 2005. ${ }^{914}$ The two aspects the group was appointed to research were as follow: the first matter involved with the question whether designating patent enforcement only to new chemical entity pharmaceuticals are TRIPS Agreement compliance; the second matter involved with the compatibility of the exclusion of micro-organisms from patent enforcement to the TRIPS Agreement. ${ }^{915}$ The following discussion is designated to the first issue as analysed in the revised report.

Follow a comprehensive analysis, the report directed on one result only: designating the eligibility of pharmaceuticals only to new chemical entity pharmaceuticals or new chemical entity pharmaceutical with one or more inventive step is contradictive to the TRIPS Agreement. ${ }^{916}$

As a part of its investigation, the group analysed whether the different flexibilities under the TRIPS Agreement can justify Section 3(d) different treatment towards pharmaceutical patenting. Arcuri and Castro defended Section 3(d) for its attempt to exclude patent protection from evergreened drugs, based on Articles 7, 8 and 27(2) to the TRIPS Agreement. ${ }^{917}$ Articles 7 and 8 promote member countries implementation of the different provisions in the TRIPS Agreement in consistency to their health and social-economic welfare characteristics and needs. Article 27(2) allows a member country to exclude patent protection to obtain public order and health. According to the authors, given that Section 3(d) offers large generic drug pool and thus promotes wider range of healthcare in India, Section 3(d) cannot be considered as discriminatory to the TRIPS Agreement. ${ }^{918}$

The Mashelkar Group examined Articles 7 and 8 reasoning in trying to justify Section 3(d) wording and result. In a reference to the South Centre Report which dealt

\footnotetext{
${ }^{914}$ See Government of India Press Information Bureau "Kamal Nath Constitutes Technical Expert Group on Patent Law Issues" (6 April 2005) Press Release.

${ }^{915}$ See Mashelkar Report, above n 831, para 2.0.

${ }^{916}$ Ibid, para 2.1.

${ }_{917}$ See TRIPS Agreement, above n 1, arts 7, 8, 27(2). See also Arcuri, Castro, above n 751, 6-16.

${ }^{918}$ Ibid.
} 
with the 'special overriding situations' in the TRIPS Agreement, ${ }^{919}$ arguments such as Arcuri'a and Castro's cannot support Section's 3(d) legitimacy in respect to Article 27(1) non-discriminatory obligation. According to the South Centre Report, Articles 7 and 8 answer situations of: ${ }^{920}$

\begin{abstract}
Necessity and of consistency with other obligations under the TRIPs Agreement. The "consistency" requirement may permit patentability exclusions in cases of distinct public health emergencies as defined by the national government, and as distinct from ordinary or everyday health and nutrition measures.
\end{abstract}

Hence from the given view presented in the South Centre Report, ordinary narrowed pharmaceutical patent scope enforcement, even in a try to answer the Indian ordinary public health through the enlargement of the generic pool of drugs, cannot be a proper justification of Section 3(d) enactment. It is unrealistic to believe that under the history of the TRIPS Agreement formation, its initiators meant to apply such a narrow patent scope as enforced by Section 3(d).

Moreover, as stated in the preface of the given South Centre Report, the reliance on Articles 7 and 8 has to be entwined with the obligation the TRIPS Agreement ordered. Patenting incremental pharmaceutical innovation ought to be considered as a part of this obligation for it represents the core of the pharmaceutical industry innovation. Article 8 explicitly noted that interpreting the interest of member countries in their domestic intellectual property laws has to be "consistent with the provisions of this Agreement." ${ }^{921}$ In other words, promising a better health care in India cannot be on the account of enforcing patent protection on the larger scale of pharmaceutical innovation as incremental innovation.

The Doha Declaration which allowed wider enforcement of compulsory licensing did oblige a full compliance with the TRIPS Agreement as stated in the Mashelkar Report. As stated in the Declaration, the TRIPS Agreement "does not and should not prevent members from taking measures to protect public health". ${ }^{922}$ Nevertheless and although health interests are of first priority, it has to be fulfilled while reiterating the

\footnotetext{
919 See South Centre www.southcentre.org (accessed 26 October 2009).

${ }^{920}$ See Mashelkar Report, above n 831, para 5.18-5.20 emphasis added.

${ }^{921}$ See TRIPS Agreement, above n 1, art 8. See also Rai, above n 458, 65.

${ }^{922}$ See Doha Declaration, above n 16, art 4.
} 
commitment under the TRIPS Agreement provisions and in this respect, to patent pharmaceutical incremental innovation.

Even in relation to Articles 27(2) which ordered of the exclusion of patent rights to protect public order, human, animal or plant life or health cannot be a proper justification. ${ }^{923}$ Although enabling better access to drugs is a prior form of protection on public's health, the exception depends on whether the patented invention causes commercial exploitation. India which seeks for cheaper drugs through generics cannot claim that incremental pharmaceutical equals to commercial exploitation in general, especially given to its own extensive innovative activity of incremental pharmaceutical innovation in the frame of novel drug delivery system. ${ }^{924}$

It is however important to stress that regardless to the result of Section 3(d) compatibility to the TRIPS Agreement, it still does not change the fact that it hinders the possibility to establish extensive patented drug market in India. Narrowing the protection only to the rare cases of new chemical entity drugs innovation, will diminish the prospectus of the Indian pharmaceutical innovative capacity growth as well as the option to offer a solution to drugs accessibility through wider patent enforcement. Several pharmaceutical firms and civil organisations expressed different views on Section 3(d) negative affect on the evolvement of the Indian pharmaceutical industry. ${ }^{925}$

Ranbaxy's view as presented in the Mashelkar Report was explicit to Section's 3(d) negative influence on its incentive to innovate. ${ }^{926}$ Until Ranbaxy expands its innovative capabilities to new drugs discovery routes and new chemical entity research, the firm relies substantially on new drug delivery system and dosages development products. ${ }^{927}$ Limiting patent enforcement on incremental pharmaceutical innovation would deter the firm to engage with research and development to answer India's specific public healthcare needs.

\footnotetext{
${ }^{923}$ See TRIPS Agreement, above n 1, art 27(2). See also Rai, above n 458, 65.

${ }^{924}$ See Rai, above n 458, 65-68.

${ }^{925}$ See Marakesh Report, above n 830, Annex III.

${ }^{926}$ Ibid.

${ }^{927}$ Ibid.
} 
The Organisation of Pharmaceutical Producers of India (OPPI) supported this view and claimed that the exclusion of non- new chemical entity pharmaceuticals from patent protection would risk the prospect of the Indian scientists to engage with productive drugs discovery processes as needed in India. ${ }^{928}$ As Ranbaxy and the OPPI, Krishna \& Saurastri, Trademarks \& Patent Attorneys in India see the importance of patenting incremental innovation. ${ }^{929}$ Although the pharmaceutical multinationals are capable of new chemical/molecule entity drugs research and development, the Indian pharmaceutical industry is not. Excluding patent protection from incremental innovation, would not allow Indian holdings on pharmaceutical patents in the market. In other words, excluding non - new chemical entity products from patent protection would strengthen the competitive superiority of pharmaceutical multinationals in the Indian market and prevent the local industry to equalise its innovative capabilities and achieve better pharmaceutical research and development tools. ${ }^{930}$ Needless to say, this reality will not contribute to the Indian innovative pharmaceutical industry evolvement.

Many opponents criticised the Indian Patent Act yet did not submit any complaint to the World Trade Organisations. ${ }^{931}$ Nevertheless, the concerns from not being able to apply for patent protection to altered drugs are considerable, as claimed by opponents to the Indian Patent Act in the United States. ${ }^{932}$ As Dean viewed, India has to find a balance between providing benefits to innovators through patent enforcement and to the national interests. ${ }^{933}$ Excluding incremental innovation from the patent scope does not seem to offer that balance.

No one can deny the importance of generics to public healthcare, for it does offer lower cost of drugs than the patented versions. Nevertheless, promoting the innovative pharmaceutical industry is not of less importance to the Indian health care, especially when it can also offer low-cost drugs market and expose the Indian industry to further sophisticated research skills and beneficial collaboration with pharmaceutical multinationals. In this respect it is also important to remind of India's

\footnotetext{
${ }^{928}$ Ibid.

${ }^{929}$ Ibid.

${ }^{930}$ Ibid.

${ }^{931}$ See Dean, above n 82, 735.

932 Ibid.

${ }^{933}$ Ibid, 736.
} 
evolving economy, exiting from poverty and the increase of the purchasing power inclusive in the sector of healthcare. ${ }^{934}$ Nevertheless, although India has made considerable steps to complete the transformation needed to its pharmaceutical industry, it is still far from achieving a wide spectrum of innovative orientation. Distancing investment and collaboration with advanced pharmaceutical firms, does not seem to answer the process.

If India would offer wide patent protection scope for pharmaceutical innovation, it would empower the innovative pharmaceutical industry and bring to a new era of healthcare through patent enforcement. When that day comes, India would not have to wait until others will invent the drugs it needs, and be able to discover new drugs on its own and focus on tropical diseases research as well. However, in order to fulfil this notion, India has to omit Section 3(d) from its Patent Act and widen the nonobviousness standard to include incremental pharmaceutical innovation. Through this suggested process and as suggested before, the Indian Government would attract more foreign direct investment to its pharmaceutical industry, more local incremental drugs would be produced and through larger competition, the industry would be able to offer drugs in lower cost, not much higher than generics cost.

As incremental innovation is based on drugs modification, altering new formulations and combinations of active substances and often approved compounds, there should not be any reason why incremental based drugs would not create the extensive competition needed to reduce drugs pricing. Under patent protection, foreign investment as suggested would increase, the industry would therefore grow and thus as generics created vast competition nation and international wide, so would incremental drugs achieve the same result. However, this time, through patent protection and not through the "notorious" generic mechanism.

Nevertheless, it should be emphasised that this avocation supports the long term run. This may encourage questioning India's readiness to answer an immediate accessibility to drugs. Compulsory licensing, in its expanded form under the Indian Patent Act would be able to answer that need and offer the balance between the two

${ }^{934}$ See part II D 1 The socio-economic outlook. 
public interests: encouraging pharmaceutical innovation and accessing to the innovated drugs. On the one hand this measure would allow the generic firm to copy drugs and market them locally. On the other hand, under the compulsory licensing mechanism, the patentee deserves some sort of remuneration. The full discretion given to the Indian Patent Controller to decide as "he deem fit" ${ }^{935}$ on the different applications for compulsory licensing and the vary considerations the Patent Controller can use to grant the application, can promise an immediate need to access drugs, without harming the patentee's interest for compensation. What is left however for the Indian Government to do is to put the compulsory licensing into use.

\section{Forming a Balance: Endorsing Wider Compulsory Licensing Utilisation in India}

Policies which exclude patenting of pharmaceutical incremental innovation can break the delicate balance between research and reimbursement for the core place incremental innovation takes in the pharmaceutical technology field. Accordingly, they can also hamper investment to a developing country as India, investment it desperately needs to advance its innovative characteristics and try to offer low cost drugs through patent enforcement in contrast from generics. In this regard and as a mean to attract as much investment and collaboration with foreign pharmaceutical multinationals as possible, some suggest omitting other restrictions Section 3 in the Indian Patents Act endorses on the eligibility of innovations, as Section 3(i). ${ }^{936}$ In this section for example any medical process, surgical, curative, prophylactic, therapeutic and diagnostic inventions or other treatment of human beings (in addition to treatments of animals and plants) are excluded from patent protection. The logic behind this suggestion is very clear. Any restrictions on patent enforcement would mean the restriction on the evolvement and growth of the local Indian pharmaceutical innovative industry and a delay of the advocated possibility to create low cost patented drug market in India.

\footnotetext{
935 The Patents Act grants the Patent Controller with wide discretion as further shown in this chapter.

${ }^{936}$ See The Patents (Amendment) Act 2002 (India), s 3(i). See Marakesh Report, above n 831, Annex III. In the report, the International Association for the Protection of Industrial Property [IAPIP] stressed the importance of the omission of at least the explanation clause in Section 3(d) further to other clauses in Section 3, as Section3(i). IAPIP added that the exclusion of non new chemical entity drug from the protection of patent as resulted from Section 3(d) should not be defined in the Act as part of the patentability criteria.
} 
Today, following the 2005 amendment to the Act which finalised the inclusion of pharmaceutical product to the patent scope and under the suggestion to omit the restrictions under Section 3(d), it is becoming more critical for India to use the flexibilities exists in the Patent Act to promise that the enforcement of patent would not deny the need to use the patented drugs. In other words, there is a need to promise that the two public interests patent tries to promote would coexist. ${ }^{937}$ It is without a doubt that seeking domestic innovation and foreign direct investment through stronger patent enforcement would affect the immediate accessibility to drugs and for that reason, compulsory licensing seems to answer the needed relief for drugs accessibility under a patent protected pharmaceutical industry. As recommended by Rai, the flexibilities under the TRIPS Agreement and the Doha Declaration have introduced the developing world with the opportunity to omit section 3(d) and still enjoy from drugs accessibility. ${ }^{938}$

Whereas the pharmaceutical industry in the developed world considerably opposes compulsory licensing, ${ }^{939}$ developing countries rely on this mechanism to develop generic equivalents to the patented drugs in time of need. ${ }^{940}$ For example, under the epidemic features of HIV/AIDS in India, when Pfizer's Fluconazole drug cost US\$17 per serving in India, its generic version cost is US\$2. ${ }^{941}$ Although the reduced price can bring to the reduction of the brand name drug price given to the generic competition, Harrelson points on the fact that under the compulsory licensing mechanism, the patentee is usually remunerated. ${ }^{942}$ The Commission on Intellectual Property Rights instituted in the United Kingdom, was considerably supportive of the compulsory licensing mechanism enforcement by developing countries and encouraged fully exploitation of the flexibilities given by the TRIPS Agreement to promise a commercial use, production and exportation of generic drugs. ${ }^{943}$

\footnotetext{
937 See Mueller, above n 311, 587.

${ }^{938}$ See Rai, above n 458, 84.

${ }^{939}$ See generally Mueller, above n 311, 583 .

${ }^{940}$ See generally Harrelson, above n $319,191$.

${ }^{941}$ Ibid.

942 Ibid, 192.

${ }^{943}$ See generally United Kingdom Commission on Intellectual Property Rights Integrating Intellectual Property Rights and Development Policy (London, 2002).
} 
One can raise concerns on the potential disputes between the pharmaceutical innovator and the generic firm on the grounds of compulsory licensing. However in practice these concerns seem to be without merit. Firstly, pharmaceutical multinationals have much to gain from the Indian pharmaceutical industry, mostly under the economic difficulties the industry experiences these days. Secondly, although generic firms will find it easier to apply and receive approved licenses from the Patent Controller, they would prefer to reach to common grounds with pharmaceutical multinationals. ${ }^{944}$ In this respect, if pharmaceutical multinationals will take their opposition beyond the Controller's tribunal to the Intellectual Property Appellant Board, it is most likely that generic firms would prefer to reach an arrangement with these firms and abandon long term disputes. ${ }^{945}$

Although under the TRIPS Agreement the use of the compulsory licensing was designated to certain urgency and emergencies times, ${ }^{946}$ the Indian formulation of compulsory licensing however crossed these boundaries. Under the Indian interpretation of Article 31 of the TRIPS Agreements the need to access drugs, under vary conditions, can be answered by the Patent Controller in vast situations inclusive times when the prices of drugs is offered in an unaffordable price. ${ }^{947}$

At the preface of the section in the Patent Act which regularise compulsory licensing, the leading considerations the Patent Controller has to take presented. These considerations widespread the patent mechanism rule enforcement in India. In this regard patent protection will be granted to encourage inventions to benefit the Indian commercial scale. ${ }^{948}$ Patent is not granted to benefit the monopoly interest of the patentee ${ }^{949}$ and in any case, it should not impede public health but promote it as well as other social and welfare needs. ${ }^{950}$ Furthermore, the Act specifically notes that the patented inventions and to this thesis concerns, drugs, have to be offered in a reasonably affordable price to the public. ${ }^{951}$ Patent has also to be enforced

\footnotetext{
${ }^{944}$ See Mueller, above n 311, 599.

945 Ibid.

${ }^{946}$ See TRIPS Agreement, above n 1, art 31.

${ }^{947}$ See The Patents Act (Amendment) Act 2002 (India), s 84(4).

${ }^{948}$ Ibid, s 83(a).

${ }^{949}$ Ibid, s 83(b), (f).

${ }^{950}$ Ibid, s 83(d), (e).

${ }^{951}$ Ibid, s 83(g).
} 
contributively to the promotion of technological innovation in India and the transfer of technology to answer local, social and economic needs. ${ }^{952}$

In addition to the automatic prioritisation given to generic firms which invested in the production and marketing of drugs covered by the "mailbox", ${ }^{953}$ compulsory licensing is given on two main levels, the private and the public. Although the Act offers the use of compulsory licensing in any field of technology, the following analysis would concentrate on its implementation on pharmaceuticals. On the private setting, following three years from the date of granting a patent, the Act allows any person or organisation, private or public, ${ }^{954}$ to apply to the Patent Controller and ask for a license to use a patented drug for example under closed list considerations. ${ }^{955}$ If the public reasonable requirements from the patented drug have not been met in respect to the patented invention, or if the drug is not available at affordable price or if it is not worked (sold) in the Indian marketplace, the Patent Controller, on the basis of these three main conditions can grant a compulsory licensing if satisfied with the facts submitted to support them. ${ }^{956}$

Nevertheless, the Act does specify what general considerations should lead the Patent Controller to the decision under the aforementioned terms. Such considerations include the nature of the invention as the field of its technology (pharmaceutical, auto), the tries of the patentee, or the licensee (if there is one) to make full use of the invention and the ability of the applicant to work the patented invention. ${ }^{957}$ These considerations join to another group of considerations as the extent of a commercial use of the patented invention, ${ }^{958}$ and that the interests of any person developing an invention in the territory of India would not be prejudiced after granting the compulsory licensing. ${ }^{959}$

\footnotetext{
952 Ibid, s 83(c).

${ }^{953}$ See The Patents (Amendment) Act 2005 (India), s 11A.

${ }^{954}$ See The Patents (Amendment) Act 2002 (India), s 84(1). See also The Patents (Amendment) Act 2005 (India), s 84.

${ }^{955}$ See The Patents (Amendment) Act 2002 (India), ss 84(1) (a)-(c), 84(2).

${ }^{956}$ Ibid, s 84(4).

${ }^{957}$ Ibid, s 84(6).

${ }^{958}$ Ibid, s 89(a).

${ }^{959}$ Ibid, s 89(b).
} 
Another consideration is the attempt of the applicant to reach an agreement with the patent holder before attaining the use of compulsory licensing. ${ }^{960}$ According to the Act, a reasonable term to try and achieve an agreement is six months. ${ }^{961}$ Despite the specification of the different considerations, the ambiguous nature of the different conditions laid before the Patent Controller and the large discretion to base the decision of granting a compulsory licensing, is clear. ${ }^{962}$ Another aspect is the eligibility for any person to apply for compulsory licensing without any restriction. ${ }^{963}$ This criterion opens the possibility for vast civil organisations to fight for an extensive generic production on every drug and protect the poor population through generic production until the strengthening of the local innovative industry.

Under the first condition in the private setting, which is based on the public unanswered reasonable requirements in respect to the invention, ${ }^{964}$ the Act does not define "reasonable" and thus enlarges the ground to permit compulsory licensing of a patented drug. ${ }^{965}$ The reasonable requirements can consist with unmet trading expectations, ${ }^{966}$ inadequate demand of the $\operatorname{drug}^{967}$ and prejudiced impact on the Indian market. ${ }^{968}$ Others exceed to general unmet export goals of the Indian market, ${ }^{969}$ difficulties the patentee has imposed on the generic firm license seeker ${ }^{970}$ and the affect on an Indian competition with the invention. ${ }^{971}$

According to the Indian Competition Act 2002, ${ }^{972}$ any enterprise prohibited from abusing its dominancy position in the Indian market through the demand of high prices. ${ }^{973}$ Hence, any commercial difficulties the patented drug for example can impose on the Indian pharmaceutical market competition would be an eligible factor

\footnotetext{
${ }^{960}$ Ibid, s 84(6).

${ }^{961}$ See The Patents (Amendment) Act 2005 (India), s 84.

${ }^{962}$ See Dhar, Gopakumar, above n 179, 21.

${ }^{963}$ See The Patents (Amendment) Act 2002 (India), s 84(1).

${ }^{964}$ See The Patents (Amendment) Act 2002 (India), s 84(1).

965 It can be said that given to the flexible criteria, the affect could be increased litigation.

${ }^{966}$ See The Patents (Amendment) Act 2002 (India), s 84(7)(a)(i).

${ }^{967}$ Ibid, s 84(7)(a)(ii).

${ }^{968}$ Ibid, s 84(7)(a)(iv).

${ }^{969}$ Ibid, s 84(7)(a)(iii).

${ }^{970}$ Ibid, s 84(7)(b).

${ }^{971}$ Ibid, s 84(7)(c).

${ }^{972}$ See The Indian Competition Act 2002.

${ }^{973}$ Ibid, s 3(4). See also generally Aparna Viswanathan "From Commanding Heights to Competition: A Comparative Analysis of India's Competition Act 2002 with UK/EC Law" (2003) 14(7) Int'l Company \& Com L Rev 229.
} 
to base an applicant for compulsory licensing. As the ground to apply for compulsory licensing is wide and flexible, the Indian poorer population should not fear from wider patent enforcement given that accessing drugs through the generic production is almost assured. The following considerations which widen the eligibility to apply for compulsory licensing clarify this aspect even more.

The second term which allows the grant of compulsory licensing under the Act, relates to a situation when the invention is not worked in the Indian marketplace. ${ }^{974} \mathrm{~A}$ non-working patent in the market can be for example, a situation when the patented drug is not sold ordinarily. One of the prior considerations regarding patent enforcement under the Indian Patent Act is the rule patent plays to benefit India's public needs of commercialisation in difference to the patentee's monopoly right. ${ }^{975}$ As the term "reasonable" was not defined in the previous term, the term "worked" is not interpreted as well. This provision is another supportive evidentiary of the ambiguous nature of the Indian compulsory licensing mechanism and the full discretion the Act intended to leave in the hands of the Patent Controller. In this respect, it is noteworthy that the Patent Controller can delay the hearing of the application of compulsory licensing to a year later of its submission, if it was found that the time the patentee had to work the patented drug was insufficient ${ }^{976}$ due to Governmental orders or different state regulations. ${ }^{977}$

An additional provision concerning the term of working the patented invention relates to any person inability to work its own invention, whether as patentee or a licensee, without the use of the secondary patented invention which is the subject of the compulsory licensing. In this respect and in an analogy to the pharmaceutical industry, if an Indian pharmaceutical firm/generic firm wishes to use a patented compound to develop another drug, it can apply for the Patent Controller with an application for compulsory licensing. ${ }^{978}$ After the Patent Controller is satisfied that the applicant is willing and able of cross-licensing the new invention to the patentee

\footnotetext{
${ }^{974}$ See The Patents (Amendment) Act 2002 (India), ss 84(1)(c), 84(7)(a),(d),(e), 85, 86.

${ }^{975}$ Ibid, s 83, 84(6).

976 Ibid, s 86.

977 Ibid, s 86.

978 Ibid, s 91(1).
} 
under reasonable terms ${ }^{979}$ and that the new invention has made substantial contribution on commercial or industrial levels in India, ${ }^{980}$ the Patent Controller, on an independent discretion can grant the compulsory licensing.

The third term to grant compulsory licensing to private applicant is in times when the price set on the patented invention and in respect to the thesis, the price set of the invented drug is beyond the reach of the local population. According to the Act, if a drug is offered in an unreasonably affordable cost to the market, an application for a license can be granted if proven to the satisfactory of the Patent Controller. ${ }^{981}$ An interesting aspect in this provision is that the definition of "reasonable" is not given and thus can allow the Patent Controller subjective grounds to decide what an unreasonable price is. ${ }^{982}$ In this respect, given that the larger average share of the Indian purchasing power is low, a reasonable price of a drug can be interpreted as low as well. Respectively, although incremental drugs would be patented, if they will be offered in a price which is not affordable in the Indian market, generic firms' application for compulsory licensing can be easily granted by the Patent Controller. ${ }^{983}$

Under the granting of compulsory licensing, the Act allows the patentee with reasonable remuneration. ${ }^{984}$ Again, one can ask what reasonable remuneration is if compared to the costly expenditures invested in pharmaceutical research and development. How much would a generic firm have to pay to the right's holder of a patented drug so it would not hinder the possibility to offer the generic version in low cost? If set high, the generic versions cost would be set high as well and the notion of low cost generic drugs would not be fulfilled. Dhar and Gopakumar presented a study which showed of an average 20 - 25 per cent proper remuneration and repeated the fact that higher royalties of the license would impact on the price of generics and harden the possibility of supplying the drug in affordable prices. ${ }^{985}$

\footnotetext{
${ }^{979}$ Ibid, s 91(2)(i).

${ }^{980}$ Ibid, s 91(2)(ii).

${ }^{981}$ Ibid, s 84(1)(b).

${ }^{982}$ See generally Mueller, above n 311, 593.

${ }^{983}$ See The Patents (Amendment) Act 2002 (India), s 90(1)(i). See also The Patents (Amendment) Act 2005 (India), s 90.

${ }_{984}$ See The Patents (Amendment) Act 2002 (India), s 90(1)(i).

${ }^{985}$ See Dhar, Gopakumar, above n 179, 22.
} 
At the same time, the Patent Controller has the responsibility to ensure that the licensee would work the patented invention to the fullest extent ${ }^{986}$ and in affordable price. ${ }^{987}$ To be noted that before the granting of compulsory licensing applications, the Act does acknowledge the right of the patentee or "any other person" to oppose to the application. ${ }^{988}$ Moreover, as the Patent Controller has the right to grant a license, the controller also has the authorisation to terminate the license when the circumstances which granted the license are expired. ${ }^{989}$

The next ground to allow compulsory licensing is based on the pubic level, in times of the public need to access a patented costly drug. National emergencies, extreme urgencies or in cases of public non-commercial use as set by the Central Government, regardless to the fact if three years has passed from the date of granting the patent, are additional grounds to grant compulsory licensing. ${ }^{990}$ Under these terms HIV/AIDS, tuberculosis, malaria or other epidemics are of a priority case in National emergencies, extreme urgencies or in cases of public non-commercial use. ${ }^{991}$ Under these terms and in difference from the previous circumstances, no preliminary negotiation with the patentee is necessary. ${ }^{992}$ Moreover, under the Patent Controller responsibilities, the manufactured drug by the licensee has to be offered in the lowest cost as possible and still enable the patentee to benefit from the rights over the invention in the market. ${ }^{993}$

As stressed earlier, India's generic industry plays a vast role in other developing countries accessibility to drugs. The compulsory licensing mechanism did not ignore that need. The Indian compulsory licensing mechanism answers the need for affordable drugs distribution in countries which do not have the manufacturing capacity to produce generics on their own. ${ }^{994}$ According to the Act, any drug, product or process of any pharmaceutical sector, inclusive ingredients and diagnostic kits will

\footnotetext{
${ }^{986}$ See The Patents (Amendment) Act 2002 (India), s 90(1)(ii).

${ }^{987}$ Ibid, s 90(1)(iii).

${ }^{988}$ Ibid, s 87(2).

${ }^{989}$ Ibid, s 94(1).

990 Ibid, s 92.

${ }^{991}$ Ibid, s 92(3).

992 Ibid, s 92(3).

${ }^{993}$ Ibid, s 81(1)(ii).

${ }^{994}$ See The Patents (Amendment) Act 2005 (India), s 92A(1).
} 
be open to compulsory licensing to answer third party needs. ${ }^{995}$ Under this provision, there is not a need to wait three years from the day of granting the patent to apply for a compulsory licensing and the Patent Controller does not have the prerogative to decline an application under this term. ${ }^{996}$ To be noted that although this term specifically concerns commercialisation of inventions to other countries, it is both scientifically and economically beneficial for Indian firms which can advance their skills through the research of the patented drug and export the generic equivalent to tens of other developing and least developed countries. ${ }^{997}$

With an extensive mechanism of compulsory licensing, such as the Indian mechanism, under the omission of Section 3(d), there should not be concerns in regards to the aspect of accessing patented drugs by the poorer population in India and in the world. The section of compulsory licensing as reviewed earlier, offers widespread options under the subjective satisfactory of the Patent Controller. This opportunity can enable the Indian pharmaceutical industry to offer lower cost drugs to the local population in addition to advance its own innovative capacity through the process of copying. Nevertheless, without a full operation of the compulsory licensing mechanism, the omission of Section 3(d) will delay accessibility to drugs by the poorer population.

Patenting incremental pharmaceutical innovation and the minimisation of the generic production rate respectively, may bring to a rise in drugs pricing before the Indian pharmaceutical industry would be able to evolve to a large an influential industry. Until that day comes, India is mostly equipped to deal with the predicament of drugs accessibility using its influential compulsory licensing mechanism. India just needs to use it.

Correa acknowledges the benefits compulsory licensing promise to foster efficient productive innovative activities by the recipient countries. ${ }^{998}$ However he does have some concerns. ${ }^{999}$ Some of these concerns rely on the fact that circumstances for

\footnotetext{
995 Ibid.

${ }^{996}$ Ibid.

${ }^{997}$ See generally Mueller, above n 311, 605.

${ }^{998}$ See Correa, above n 520, 250.

${ }^{999}$ Ibid.
} 
compulsory licensing may change. Prices of drugs can be normalised to fit the purchasing power of the Indian population and thus there would not be any justification to grant a compulsory license to the applicant. ${ }^{1000}$

Furthermore, patent holders can place economic and political pressure on applicants who would drive domestic firms to withdraw their application and choose a different option than litigation. ${ }^{1001}$ This aspect was also reviewed by Basheer, who stressed that "the mere existence of such legal flexibilities does not mean that they will necessarily be exploited". ${ }^{1002}$ In his study Basheer noted that among 103 Indian firms which were asked of the economic beneficial promised by the exporting of generics authorised by compulsory licensing, only 25 firms answered positively. ${ }^{1003}$ To the economic considerations join political considerations.

Basheer completed the aspect of the economic and political considerations which lie in the mechanism of compulsory licensing when he said that the decision is of two Governments, not one. ${ }^{1004}$ Correa however, which did see the same elements as Basheer, encouraged countries to resist the potential economic and political pressure and push the patentees to reduce the patented inventions pricing through compulsory licensing. ${ }^{1005}$ Accordingly Correa saw in compulsory licensing as an important bridge between a wide enforcement of innovation protection and other given flexibilities in the TRIPS Agreement ${ }^{1006}$ as the Bolar exception ${ }^{1007}$ and the parallel importation, ${ }^{1008}$ which also implemented in the Indian Patent Act and can bring to the reduction of drugs pricing.

It is clear that the Indian Patent Act offers various tools for the Indian Government to enable better accessibility to drugs, even under a larger enforcement of patent, inclusive incremental pharmaceutical innovation. Nevertheless, on the other hand,

\footnotetext{
${ }^{1000}$ Ibid, 248.

${ }^{1001}$ Ibid, 248, 489.

1002 See Shamnad Basheer "India's New Patent Regime: Aiding "Access" or Abetting "Genericide"?

(2007) 9(2) International Journal of Biotechnology 122, 131.

1003 Ibid.

${ }^{1004}$ Ibid, 133.

${ }^{1005}$ Ibid. See also Correa, above n 520, 248 - 249.

1006 Ibid, 255.

${ }^{1007}$ See The Patents Act (Amendment) Act 2002 (India), s 107A.(a)

1008 See The Patents Act (Amendment) Act 2002 (India), s 107A.(b).
} 
revoking Section 3(d) and operating the mechanism of compulsory licensing without inhibitions is not advised as well. The Indian Government is expected to manage compulsory license wisely to encourage cooperative atmosphere instead of combative. ${ }^{1009}$ It would be most unadvised for countries to use this flexible regularly and exhaust the patent mechanism they are obliged to implement on pharmaceuticals. Although compulsory licensing is advised under a wider enforcement of patent on pharmaceuticals, countries need to balance its use with the protection over incremental pharmaceutical innovation.

Time brings changes. Time has strengthened the Indian innovative pharmaceutical industry. India however should not fear from these changes and see that patent can offer low cost drugs in the marketplace as long as it is wider, especially in a growing, emerging country as India. However the option of patent's offering a solution for drugs pricing in developing countries will not form overnight and until it does, India has to allocate enough elements to promise affordable drugs for the local population. India would just have to be prepared to use them openly and wisely for they will bring the needed balance between patent innovation encouragement and accessibility to the inventions.

Nevertheless, as much as India can fulfil its part to build a low cost patented drug marketplace, through the enlargement of protection of pharmaceutical incremental innovation, it is not only up to India to complete the transformation. In this respect the next chapter tries to fit the pharmaceutical multinationals role in assisting India to evolve and establish a stronger innovative pharmaceutical industry, one which would answer the local need of lower cost drugs. In addition to a legal obligation, the economic prospectus form collaborating with the Indian pharmaceutical industry, pharmaceutical multinationals in developed countries carry the moral responsibility for philanthropy activity in developing countries. This point is the final avenue which ought to be closing the analysis of patent protection impact on developing countries accessibility to drugs and imply that the process is not one sided, but two.

${ }^{1009}$ See Ford, above n 465, 966. 
VII IT IS NOT ONLY LOCAL OBLIGATION: MAKING DRUGS ACCESSIBLE IN DEVELOPING COUNTRIES - A GLOBAL RESPONSIBILITY

Although the TRIPS Agreement sketches various flexibilities which can be enforced by developing countries to access patented drugs and oblige developed countries to assist developing countries with technical needs and the transfer of technology, ${ }^{1010}$ the Agreement does not oblige the developed world to assist the poorer population by offering low cost drugs. It is in this respect important to analyse whether this responsibility can be drawn from the moral avenue. One of the most significant influential forces on the developing world infrastructure reinforcement is the activity conducted in these countries by Non Governmental Organisations. These organisations assist the developing world in the different social and economic areas as child health, women's' rights, build roads, hospitals and schools. ${ }^{1011}$ Departed from any political constraints and the direct work with local organisations are two main advantages Non Governmental Organisations have which make them more approachable to ask for assistance from the different Governments in the developed world. ${ }^{1012}$ In practice these organisations have the power to affect the lives of 250 million people in the developing world. ${ }^{1013}$

However, as vast as the activity of Non Governmental Organisations activity is cardinal, working alone, without pharmaceutical multinationals assistance, the healthcare spectrum in developing countries would not change as quickly as it can. Nevertheless, much encouragement is still needed. As of today there is an insufficient assistant from the developed world. ${ }^{1014}$ In 2003, the United States Congress authorised to increase the funds designated to transfer HIV/AIDS treatment to developing countries. ${ }^{1015}$ Nevertheless according to Abbott, the budget is still low. ${ }^{1016}$ According to the External Medicine Policy which formulated by the United States Trade Representative to answer the United States interests in the pharmaceutical

\footnotetext{
${ }^{1010}$ See generally Dreyfuss, above n 132, 14.

1011 See generally Todaro, Smith, above n 11, 736-737.

1012 Ibid.

1013 Ibid.

${ }^{1014}$ See Dean, above n 82, 734.

${ }^{1015}$ Abbott, above n 257, 397.

${ }^{1016}$ Ibid.
} 
research field, very little consideration was left to drugs accessibility in developing countries. $^{1017}$

The 2001 report of the High Commissioner of the United Nations on the issue of the TRIPS Agreement and the impact it has on human rights, specifically ordered member states to assure that accessibility to health in developing countries would be wide - ranged and include the establishment of health facilities and goods (drugs for example) regardless to their public or private originality source. ${ }^{1018}$ Countries were called to assist on an international level and cooperate with each other in a way which would merge their innovative activity into their commitment to fulfil the predominant right of health in developing countries. ${ }^{1019}$

The United Nations sub-Commission on the Promotion of Human Rights affirmed that the TRIPS Agreement did not reach a proper balance between the right of property and the right for health. ${ }^{1020}$ Accordingly the Commission suggested that civil organisations should promote an economic policy mechanism to respect their existing human rights obligations. ${ }^{1021}$ The World Health Assembly Resolution on Public Health Innovation and Essential Health Research and Intellectual Property Rights, concerned the exact matter of the impact granting property rights would have on drugs accessibility in low-middle income countries with low purchasing power. ${ }^{1022}$ On the one hand the resolution did acknowledge the standee of intellectual property right as a human right. ${ }^{1023}$ On the other hand, the concerns regarding to drugs accessibility was also noted. ${ }^{1024}$

\footnotetext{
${ }^{1017}$ Ibid.

${ }^{1018}$ See UN Commission on Human Rights "Economic, Social and Cultural Rights: The Impact of the Agreement on Trade-Related Aspects of Intellectual Property Rights on Human Rights" (27 June 2001) E/CN.4/Sub.2/2001/13, 5.

${ }^{1019}$ See UN Economic and Social Committee General "The Right to the Highest Attainable Standard of Health (Article 12 of the International Covenant on Economic, Social and Cultural Rights)" (11 August 2000) E/C.12/2000/4, para 38.

${ }^{1020}$ Ibid, para 39.

${ }^{1021}$ See UN Sub - Commission on the Promotion and Proteciotn oF Human Rights "Intellectual Property Rights and Human Rights" (17 August 2000) E/CN.4/SUB.2/RES/2001/21, para 14.

${ }^{1022}$ See WHO World Health Assembly Public Health, Innovation, Essential Health Research and Intellectual Property Rights: Towards a Global Strategy and Plan of Action (WHA59.24, Geneva, 2006).

${ }^{1023}$ Ibid, 39 - 40.

${ }^{1024}$ Ibid.
} 
Respectively, at the $61^{\text {st }}$ World Assembly on 24 May 2008, countries were called to take pro-active measurements to fulfil their obligation to protect public's health in parallel to protecting the right of property for any of their scientific, literature or any artistic production. ${ }^{1025}$ In this respect, utilising patent enforcement to create low cost drugs market in a developing country such as India is a long term solution. Wide scope patent enforcement to include incremental pharmaceutical innovation would not answer the immediate need to access drugs and as Resnik said: "for better or worse, the people of developing nations need help from the pharmaceutical industry". ${ }^{1026}$

Although significant number of patented antiretroviral drugs are listed in the World Health Organisation essential drug list, which are sold in low cost, many people living in developing countries still cannot afford them without supplementary assistance from the international community. ${ }^{1027}$ HIV/AIDS is not the only disease characterised the developing world. Although AIDS is the number one killer in developing countries, developing countries are burdened with other diseases as cancer, ineffectual diseases, diabetes, heart diseases and other health conditions. The diseases spectrum thus shows that finding cures to all, independently, is beyond the developing world current financial reach and thus it is clear that an international cooperation and financial aid is essential for the survival of people living in developing countries. ${ }^{1028}$

Lacking adequate innovative skills to fight infectious diseases, developing countries, as India, need the West's assistance before becoming "therapeutic orphans". ${ }^{1029}$ This way, to the legal and political obligations the pharmaceutical industry has in respect to people living in developing countries, joins the moral and social obligation to assist developing countries to better their accessibility to medicine.

\footnotetext{
1025 See WHO World Health Assembly Global Stategy and Plan of Action on Public Health, Innovation and Intellectual Poprerty (WHA61.21, Geneva, 2008).

${ }^{1026}$ David B Resnik "Developing Drugs for the Developing World: An Economic, Legal, Moral, and Political Dilema" (2001) 1(1) Developing World Bioethics 12, 16.

${ }^{1027}$ See Abbott, above n 257, 394- 395.

${ }^{1028}$ Ibid, 396.

${ }^{1029}$ See Resnik, above n 1026, 16.
} 
Although there are economists who do not see any moral responsibility of corporations to the less fortunate, ${ }^{1030}$ there is who regard these responsibilities as prime considerations, ${ }^{1031}$ which partly derived from social obligations of these corporations to the consumers public. ${ }^{1032}$ In respect to the pharmaceutical industry, these responsibilities translated to offer drugs in low cost for people with low purchasing power. ${ }^{1033}$ Resnik sees the pharmaceutical industry obligation to offer low cost drugs as a way to compensate the developing countries for using their low cost services. $^{1034}$

Pharmaceutical firms which activate in the sacred work of drugs innovation, have responsibility to humankind and not only to the United States richer population. ${ }^{1035}$ Nevertheless, Resnik appreciated the need of the pharmaceutical industry to return its investment and aspire to balance this need with the need of the sick and poor to access drugs. ${ }^{1036}$ Thus as long as firms enjoy from increasing profits margin, they should use these profits to answer their social responsibilities and assist developing countries with discounts on drugs, research and development for tropical diseases and invest in other social health programs to enable better accessibility. ${ }^{1037}$

Many pharmaceutical firms do see their responsibilities towards a better world's health care prospect. A prime example is the philanthropy activity conducted by the pharmaceutical manufacturer GlaxoSmithKline PLC. ${ }^{1038}$ GlaxoSmithKline announced it is willing to offer much cheaper prices for its tropical diseases drugs (for example Hepatitis B and malaria) to the 50 poorest countries in the world. ${ }^{1039}$ Additionally, the firm announced that 20 per cent of its sales profits would be used to build health clinics in these countries ${ }^{1040}$ which needless to say support the prospect of innovative independent pharmaceutical industry in the developing world's region. Another

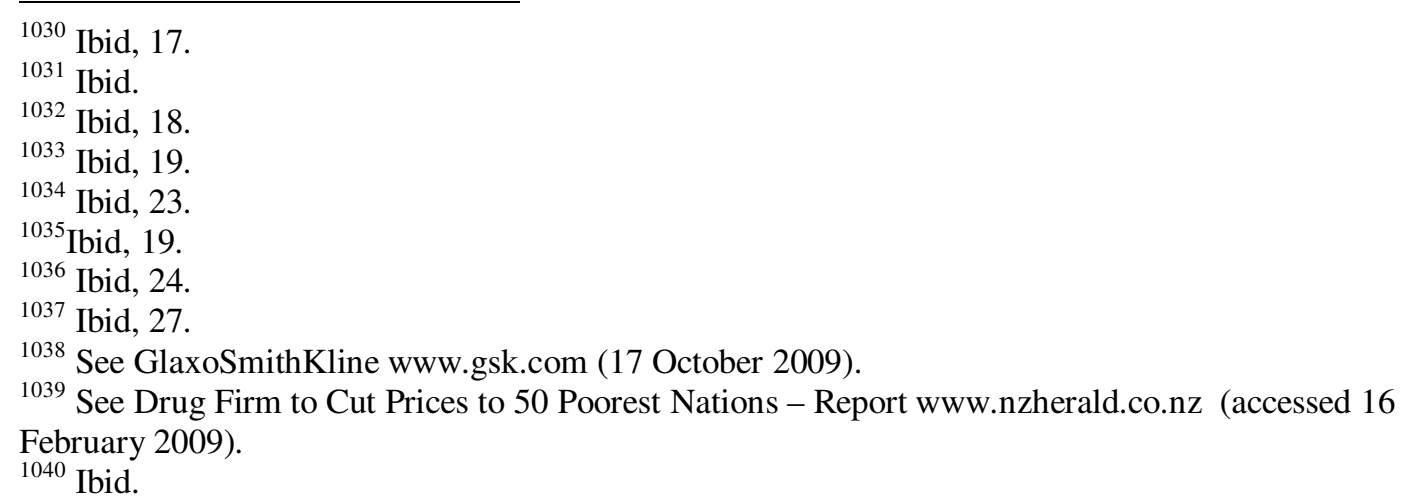


example is the establishment of the Drugs for Neglected Diseases initiative which started with US\$250 million by MSF and a group of developing countries to conduct research and development for tropical disease which their research was neglected by the Western pharmaceutical industry. ${ }^{1041}$

Another example is of Pfizer, a North-American pharmaceutical firm engagement in activity to better the developing world health care through different collaborations and partnerships with researchers in the developing world in special attention to tropical diseases. Pfizer put emphasise not only on philanthropy work but training and educating health care workers in developing countries, building health care facilities and sharing its practices. ${ }^{1042}$

The Novartis Foundation for Sustainable Development commemorated in 2009 a 20 years anniversary of fighting leprosy in India. ${ }^{1043}$ Since 1989 the nonprofit Novartis Comprehensive Leprosy Care Association has been providing services to thousands of leprosy patients across India. ${ }^{1044}$ If two decades ago leprosy afflicted the lives over 10 million people, as of today, the disease considered as eliminated. ${ }^{1045}$ However, due to India's large size, it suffers from high numbers of new cases of leprosy every year. ${ }^{1046}$ Since the year 2000, Novartis has donated drugs for leprosy worldwide through auspices of the World Health Organisation, a donation of US\$60 million which helped curing over 4.5 million patients. ${ }^{1047}$ In respect to Novartis, it is important to mention its initiated program in 2006 to allow a free from charge use of its drugs to 34 million disadvantaged patients across the developing world which was estimated in US\$755 million donation. ${ }^{1048}$

Although today's tough economic times to the pharmaceutical industry, Richard T. Clark, Chairman, President and CEO of Merck \& Co, Inc said that: "At Merck,

\footnotetext{
${ }^{1041}$ See generally Grace, above n 17, 41.

1042 See generally Pfizer Investment in Health www.pfizer.com (accessed 1 October 2009) see also Global Health Fellows www.pfizer.com (accessed 1 October 2009).

${ }^{1043}$ See Novartis Marks 20-Year Commitment in the Fight against Leprosy www.novartis.com (accessed 1 October 2009).

1044 Ibid.

1045 Ibid.

1046 Ibid.

1047 Ibid.

${ }^{1048}$ See Glivec Patent Case in India: Fact vs. Fiction, above n 850.
} 
however, we believe that good corporate citizenship and good governance have never been more important. Doing the right thing - even when times are tough - makes good business sense." ${ }^{1049}$ In its 2008 Global Corporate Responsibility Report, Merck's continued work with international groups to facilitate drugs accessibility to the world's poorest countries was widely covered. ${ }^{1050}$ In specific Concern to the HIV/AIDS epidemic, it was also reported that as of the end of 2008, 653,867 patients and 111,471 of whom are children were treated partly with one of Merck's antiretroviral drugs free of charge. ${ }^{1051}$

In different publication Merck's collaboration with Qiagen N V ${ }^{1052}$ a pharmaceutical firm from Netherlands (home -based) to fight cervical cancer in the developing world, was announced in September 23 of this year (2009). Merck announced that it would provide up to five million doses of the drug Gardasil and QIAGEN announced that it intends to donate US\$1 million worth test donation program to screen 500,000 women for the disease. ${ }^{1053}$ According to G McGlynn, president, Merck Vaccines and Infectious Diseases every passing minute another woman is being diagnose with cervical cancer, which their majority is sourced in developing countries. ${ }^{1054}$ Needless to say contributions as described above can minimise the hurt and suffering of millions of women in the developing world.

The Wellcome Trust and Merck \& Co, Inc announced in 17 September this year (2009) of the creation of the MSD Wellcome Trust Hilleman Laboratories, the first research and development joint venture with not-for-profit organisation to assist developing countries accessibility to needed medicine. ${ }^{1055}$ In addition to developing new vaccines, Hilleman Laboratories announced that it will focus on better accessibility to existing ones. According to the statement the venture will take place in

\footnotetext{
${ }^{1049}$ See Merck \& Co, Inc Publishes 2008 Global Corporate Responsibility Report, Merck Says Good Corporate Citizenshup and Governance Have Never Been More Important www.merck.com (accessed 1 October 2009).

${ }^{1050}$ Ibid.

1051 Ibid.

${ }^{1052}$ See Qiagen N V www.qiagen.com (acceded 17 October 2009).

${ }^{1053}$ See Merck and QIAGEN Collaborate to Accelerate Access to Cervical Cancer Vaccination and Screening in Developing Countries www.merck.com (accessed 1 October 2009).

1054 Ibid.

${ }^{1055}$ See Wellcome Trust and Merck Launch First of Its Kind Joint Venture to Develop Affordable Vaccines for Low-Income Countries www.merck.com (accessed 1 October 2009).
} 
India to broaden partnerships with vast experts in vaccine research and enlarge manufacturing and mature the firm's products pipeline. ${ }^{1056}$

Acknowledging the right of the pharmaceutical industry to prevent counterfeiting and return its investment in drugs research and development, Resnik conditioned the pharmaceutical industry social and moral responsibilities with patent enforcement. Resnik based his view on rather pragmatic ground. Once pharmaceutical firms would be exposed to generic counterfeiting, there would not be any profit to return back to society. There would not be any possibility for firms to assist with low cost drugs or health programs. ${ }^{1057}$ There has to be reciprocal arrangement between large pharmaceutical firms and developing countries Governments.

Implementing Resnik perspective, if India offers patent enforcement for incremental innovation and enlarges the prospect of revenues of pharmaceutical firms, and still these firms would not activate to answer India's need for assistance, India would have more legitimacy to enforce wider ranged of compulsory licensing. Given that the TRIPS Agreement does not consist with provisions to oblige developed countries to assist developing countries, assimilating this responsibility in a legislative frame is of great importance. On the other hand, if India will continue to deny protection from incremental innovation, than pharmaceutical multinationals should not be blamed for not answering to their moral obligations for they will not have enough capital to allocate to developing countries. It is in this respect noteworthy to stress that although the moral and social responsibilities of pharmaceutical multinationals is of great importance, there are complementary steps the developing world has to take to enable firms to answer these obligations.

Drexel in comparison to Resnik does not see any harm for the pharmaceutical industry in marketing free from cost drugs to the developing world's markets. Given to the marginal loss pharmaceutical firms can suffer from not selling drugs in developing countries' markets, Drexel supported that the pharmaceutical industry can fully donate free from charge drugs to the developing world. ${ }^{1058}$ However one aspect

\footnotetext{
1056 Ibid.

${ }^{1057}$ See Resnik, above n 1026, 27.

${ }^{1058}$ See Drexel, above n 77, 721, 725.
} 
that Drexel did not answer to is the growing markets in countries such as India, Brazil and China which given to their large markets and growing purchasing power, donating free of charge drugs can cause the industry of greater loss than marginal.

On a similar justification to Drexel's, different pricing of drugs based on a country's purchasing power, can be another way for the pharmaceutical industry to answer its moral obligation to the developing world's poor and sick population. ${ }^{1059}$ Presuming that pharmaceutical multinationals can retain the research and development investment from sails in the developed world's markets, ${ }^{1060}$ firms would be able to partly subsidise drugs in developing countries, ${ }^{1061}$ especially when selling bulk drugs. ${ }^{1062}$ In practice there is a variety of drugs pricing differentiation policies practiced by different countries, poorer and richer, based on different economic variables consideraitos as purchasing power. ${ }^{1063}$

Answering the moral obligation of the pharmaceutical industry towards developing countries need to access medicine is of a growing obligation as bounded by the United Nations. Although the TRIPS Agreement did not oblige developed countries to offer lower cost drugs to developing countries, the moral and social considerations do. The understanding of the importance of donating free of charge drugs and assisting the developing world in their tries to access affordable drugs has grown along the years, especially with wider expectations from these countries to enforce larger scope of patent protection on pharmaceutical innovation.

Protecting incremental innovation in this respect is of a colossal demand from the developing world for it has a direct impact on the minimisation of the generic drugs pool and thus on accessing needed drugs in low cost. Although in time, the same protection on pharmaceutical incremental innovation would elevate the Indian

\footnotetext{
${ }^{1059}$ See Abbott, above $\mathrm{n} 257,417$. See also WHO Commission on Macroeconomics and Health Differentiated Pricing of Patented Products (Working Paper No 63 Revised, New Delhi, 2001) 1,8. ${ }^{1060}$ See Abbott, above n 257, 417.

1061 Ibid.

${ }^{1062}$ Ibid, 418 - 419. Contrast to Jean Pierre Garnier, the CEO of Glaxosmithkline said that he is not a head of a chariteable institution and there should not be any similar excepctations to act as one. See Jean Pierre Garnier, Head of Glaxo, Special AIDS Report www.guardian.co.uk/aids. See also Yolanda Tayler (ed) "Battling HIV/AIDS: A Decision Maker's Guide to the Procurement of Medicines and Related Supplies" (The World Bank, Washington DC, 2004) 1, 135.

${ }^{1063}$ See generally Drexel, above n 77, 721, 725.
} 
innovative pharmaceutical industry to offer lower cost drug market through patent enforcement, until that day comes, the Western pharmaceutical industry has to justify its expectations from the developing world by promising, at least, its population healthcare. In other words, homogenous patent enforcement by the international community cannot stand alone without supporting the weaker party in the process of its emergence, especially when the right that is in stake is the most sacred rights of all, the right of health. 


\section{CONCLUSION}

Realising that patent does not only imbue the individual exclusivity rights in the marketplace but introduce new needed products to the public, highlights the importance of patent enforcement in developing countries. Patent protection can encourage more innovation, advanced technological products introduction to the marketplace and industrialise the developing world to become one with the economic developed region. This realisation is most relevant in a developing country such as India, with growing innovative skills, quality speaking English workforce and evolving economy which can be proven in the avenue of the pharmaceutical technology field.

The link between patent and growth not only implies of the prospect of the Indian pharmaceutical industry enjoyment from high extent of local innovation, it can imply of the possibility to establish an extended patent - based pharmaceutical marketplace, one which would be able to offer low cost patented drugs given to high competition levels. Given the prospectus rise from poverty, the growth of local purchasing power and thus the growth of the consumer marketplace, the opportunity of India to benefit from patent and utilise it to expand the competition in the pharmaceutical marketplace can be a reality. As long as the Indian industry would engage with innovation, grow and offer high quantity of new drugs, pioneer/incremental, the reality of reduced patented drug cost is near. In other words, the opportunity to change the common perspective on patent, as a dangerous mechanism to enforce on pharmaceutical innovations in developing countries is rising. It can therefore be said that patent's role as a barrier to drugs accessibility in developing countries is a breakable myth.

It should be noted however that the thesis does not suggest of the abolishment of the generic industry in India or in any other developing country. The generic industry has a colossal contribution to the health care promotion in these countries through low cost drugs production. If a generic version of an HIV/AIDS drug can be offered in US\$2 instead of US\$17 in countries such as India with epidemic rates of HIV/AIDS and high poverty, there should not be a doubt of the vitality of the generic production to the population health care. 
Nevertheless, and in respect to the generic production immense importance to drugs accessibility, it lacks to answer additional elements involves in the prospect of health care in the developing world. As a result of the generic industry's reliance on existing drugs, it can fail to offer drugs to the sick for it has to wait until the original drug is innovated. The generic industry does not advance the innovative skills of the pharmaceutical industry to enable it to conduct research on tropical diseases. Lastly, in a time ruled by intellectual property rights regime, the generic industry does not promise the economic benefits as Indian innovative based drugs can.

India however, has chosen to prioritise the generic production as the only source to access drugs and ruled out the opportunity to achieve the same result through patent enforcement on pharmaceutical innovations. After all, India is still a low-middle income developing country which suffers from high rates of poverty, sickness and poor education. However India is soon to be an industrialised developed country, with one of the largest consumer economies in the world. These parameters can indicate of the growing possibilities for the Indian population to afford patented drugs under their original cost, especially incremental modified innovative drugs.

Furthermore, the diversification the Indian pharmaceutical industry has accomplished by practicing in innovative research and development in parallel to generics can also indicate of the preparedness of the industry to engage with larger innovative activity. The revolutionised Indian economy and pharmaceutical industry can testify of the solid platform India has to offer low cost patented drug marketplace in the near future. However, without some alterations to the Indian Patent Act to encourage the local industry to introduce more innovative based drugs to the marketplace, ones which promote the patenting of pharmaceutical incremental innovation, establishing low cost patented drugs marketplace will stay an unfulfilled notion.

Although India signed the TRIPS Agreement and obliged to patent pharmaceutical innovation, process and products, India has narrowed the eligibility of pharmaceutical substances for protection. In this step not only India ignored from the obligation under the TRIPS Agreement to offer patent protection to all fields of technology, it also 
ignored from the generic incompetence and the alternative solution patent can offer to a better healthcare condition in the country.

The equation as analysed in the fifth and sixth chapters is very clear. As patent was proven to be a key factor to induce foreign direct investment as well as to its encouragement of pharmaceutical innovation, it can promote excessive innovative based drugs competition. Nevertheless, in order to offer the use of patent mechanism as an alternative route of low cost drugs market, the entire industry needs to join the practice of innovation. It would not be enough to allocate only large sized firms to the practice. Foreign direct investment can offer that needed expansion. As shown in the fifth chapter, since India has signed the TRIPS Agreement and joined the World Trade Organisation, the pharmaceutical industry has enjoyed from numerous partnerships and collaborations with Western pharmaceutical firms. These collaborations not only have endowered the Indian industry with more capital for research and development processes, it also allocated needed education, management skills, contacts, which showed of the potential such investment has in the creation of large scaled Indian pharmaceutical industry. Theory also suggests the importance of foreign direct investment to encourage the formation of new firms in the host country which is of vital importance to widen the competition in the marketplace.

As foreign direct investment, was proven to be strongly connected to patent enforcement in the host country, especially in the pharmaceutical industry, it can therefore be concluded of patent's contribution to establish access to drugs in the developing world and not otherwise. Pointing at the power patent has to induce investment to the Indian pharmaceutical industry and enlarge it, presents only one level of the advocated use of patent as an alternative vehicle to low cost drugs marketplace in India.

Encouraging more Indian pharmaceutical firms to engage in innovation is not much a reality once the only protected innovation is new chemical entity drug. The Indian innovative pharmaceutical industry is in the beginning stage of its formation and it is far from having enough capital to conduct research solely on new chemical entity drugs. Furthermore, being a case of rarity, new chemical entity drugs cannot offer the competitive edge as incremental based drugs can. Offering various 
equivalent drugs to answer one health condition can clearly increase the competition in the Indian pharmaceutical industry and create forceful competition to reduce drugs pricing. Not only it is within the frame of the Indian pharmaceutical industry capital capacity in small to large sized firms, it is also in the capacity of the industry scientific skills which can be fully completed by partnering with Western firms.

Thus, excluding protection from the norm innovative based drugs not only subtracts the motivation of innovation, it also subtracts investment by pharmaceutical multinationals and destructs the fulfilment of offering low cost patented drug market in India. Without patent enforcement of incremental innovation, less investment would be directed to the Indian pharmaceutical industry, fewer firms would be formed, fewer drugs would be introduce to the market, the large based firms would focus their research activity to answer the richer markets needs and generic production would remain the only route to access drugs.

It is however noteworthy to mention that realising a vast pharmaceutical competition in the Indian marketplace is of a long term creation. For this given reason, the thesis does not ignore the immediate need to access drugs and promotes the use of generics production in parallel to wider enforcement of patent. No one should be denied from needed essential drug use, regardless whether it is required by the richer population or the poorer. Health should not be a function of wealth and should never be interpreted as one. Thus, as long as the Indian Government would respect the Western pharmaceutical industry need, and to this matter, its own pharmaceutical industry need to enjoy from patent protection of pharmaceutical incremental innovation, the Government use of compulsory licensing should be more acceptable. Through the compulsory licensing mechanism, the patentee is being compensated and the poor and sick population is benefited from low cost generic versions of needed drugs.

Notwithstanding the use of compulsory licensing as offered by the TRIPS Agreement and the Doha Declaration, the thesis does not encourage an extensive use of this mechanism. A prevalent use of compulsory licensing can contradict in result the obligation India would have to enforce wide scope of patent protection on pharmaceutical innovations. In this regards and in a try to reach a balance between 
the need of the pharmaceutical industry to protect its costly innovations and the need of the Indian population to access drugs, the stronger party to this scale, the Western pharmaceutical industry, has to answer a moral-social obligation towards India's health needs. Although the legislative outline does not oblige the developed world to assist the poor economies in the world to access needed medicine, as the parable of the Good Samaritan suggests, the pharmaceutical industry in the developed world has to devote a relative share of its revenues to the ones which cannot enjoy from a minimal state of health and conduct quality lives.

Health is a core factor in the cycle of life. Health is the source of human capital, education, productivity and further economic and social benefits. Health is not a right given to the richer population of the world. Health is a right given to all human beings. However, health is a costly product. Innovating drugs is a process which entails hundreds of millions of dollars and for that indisputable fact, patenting the costly invention is of an immense importance for the pharmaceutical industry. This truth cannot be applied only in developed countries, but also in developing countries. The latter however cannot find any comfort in this truth. Enforcing patent protection on pharmaceutical innovation substances increases the cost of health to an unaffordable cost in the developing world. Relying on generics to access drugs for such a long time, blinded the developing world from an alternative way to enjoy low cost drugs through patent.

Narrowing the patent eligibility scope of pharmaceutical innovation can expend the generic drug pool. Generics production can offer low cost drugs and it can offer it today. However, generics do not answer the wide health spectrum in the developing world. Generics production cannot benefit the Indian pharmaceutical industry with innovative skills. Generics cannot invite collaboration with Western firms in the avenue of innovation, invite capital investment and thus it cannot answer the ultimate need in the developing world to find cures to tropical diseases. Not only wide patent enforcement scope can answer these needs, through their fulfilment, India would be able to offer better healthcare to its population in low cost. Through their fulfilment India would come to learn that patenting pharmaceutical innovation is not a threat to its population, but a promise of better health. It is time to acknowledge patent as an 
elevating force of health, not only in richer countries, but in developing countries as well. 


\section{BIBLIOGRAPHY}

\section{A. Primary Sources}

1. Legislation

(a) International legislation

- Canada:

An Act respecting Patents of Invention 1985.

- India:

The Indian Competition Act, 2002.

The Patents Act, 1970.

The Patents (Amendment) Act, 2002.

The Patents (Amendment) Act, 2005.

- United States:

Drug Price Competition and Patent Term Restoration Act of 1984.

Food and Drug Administration Amendments Act of 2007.

35 USC s 111.

35 USC s 101.

2. Constitutional, parliamentary and government sources

- India:

Mashelkar, R A, Chairman, Director General Council of Scientific and Industrial Research, Report of the Technical Expert Group on Patent Law Issues (Prepared for the Indian Government, 2009).

Reddy, Satwant and Gurdial Singh Sandhu Report on Steps to be taken by Government of India in the Context of Data Protection Provisions Of Article 39.3 of TRIPS Agreement (Prepared for the Government of India, 2007).

The Indian Constitution.

(24 March 2005) The Indian Parliament Lok Sabha XIV "Combined Discussion on the Statutory Resolution regarding disapproval of Patents (Amendment) Ordinace, 2004 (No7 of 2004) and passing of the Patents (Amendment) Bill, 2005 (Resolution negatived and Bill Passed)". 
- United Kingdom:

Grace, Cheri Leveraging the Private Sector for Public Health Objectives: A Briefing Paper for DFID on Technology Transfer in the Pharmaceuticals Sector (prepared for the British Government's Department for International Development, 2004).

Grace, Cheri The Effect of Changing Intellectual Property on Pharmaceutical Industry Prospects in India and China: Considerations for Access to Medicines (prepared for the British Government's Department for International Development, 2004).

United Kingdom Commission on Intellectual Property Rights Integrating Intellectual Property Rights and Development Policy (London, 2002).

- United States:

President's Commission on Industrial Competitiveness Global competition: The New Reality: Preserving America's Industrial Competiveness a Special Report on the Protection of Intellectual Property Rights (v II, President's Commission on Industrial Competitiveness, Washington DC, 1985).

The Congress of the United States How Increased Competition from Generic Drugs Has Affected Prices and Returns in the Pharmaceutical Industry (Washington DC, 1998).

The Congress of the United States, Research and Development in the Pharmaceutical Industry (Washington DC, 2006).

United States International Trade Commission Foreign Protection of Intellectual Property Rights and the Effects on the US Industry and Trade (USITC, Wahington DC, 1988).

\section{Press releases}

Government of India Press Information Bureau "Kamal Nath Constitutes Technical Expert Group on Patent Law Issues"(6 April 2005).

PhRMA "PhRMA Welcomes Passage of Patent Bill in India” (23 March 2005)

"Traditional Western Business Model" (20 June 2008).

\section{B. Secondary Sources}

1. Texts

Beier, Friedrich - Karl and Gerhard Schricker (eds) GATT or WIPO? New Ways in the International Protection of Intellectual Property (v 11, Vch Pub, Germany, 1989).

Bessen, James and Michael J Meurer Patent Failure: How Judges, Bureaucrats, and Lawyers Put Innovators at Risk (Princeton University Press, Princeton, 2008). 
Blomstrom, Magnus, Ari Kokko and Mario Zejan Foreign Direct Investment: Firm and Host Country Strategies (Palgrave, New York, 2000).

Correa, Carlos M Intellectual Property Rights, the WTO, and Developing Countries: the TRIPS Agreement and Policy Options (Zed Books, London, 2000).

Farquhar, Irina, Kent Summers and Alan Sorkin (eds) Research in Human Capital and Developmemt Investing in Health: The Social and Economic Benefits of Health Care Innovation (vol 14, Elsevier Science, Oxford, 2001).

Gadbaw, Michael R and Timothy J Richards (eds) Intellectual Property Rights: Global Concerns, Global Conflicts? (Westview Press, United States of America, 1988).

Gakhar, Kamlesh Foreign Direct Investment in India 1947 to 2007 Policies, Trends and Outlook (New Century Publications, New Delhi, 2006).

Hegel, G W F Outline of the Philosophy of Right (Oxford University Press, New York, 2008).

Locke, John Two Treaties of Government (vol V, London, 1823).

Maskus, Keith E and Jerome H Reichman (eds) International Public Goods and Transfer of Technology Under Globalized Intellectual Property Regime (Cambridge University Press, New York, 2005).

Matthews, Duncan Globalising Intellectual Property Rights The TRIPS Agreement (Rouledge , London, 2002).

Pugatch, Meir Perez (ed) The Intellectual Property Debate Perspectives from Law, Economics and Political Economy (Edward Elgar Publishing, Massachusetts, 2006).

Smith, Stephen C and Michael P Todaro Economic Development (10ed, Pearson Education Limited, London, 2009).

Spence, Michael Intellectual Property (Oxford University Press, New York, 2007) 52.

Tayler, Yolanda (ed) "Battling HIV/AIDS: A Decision Maker's Guide to the Procurement of Medicines and Related Supplies" (The World Bank, Washington DC, 2004).

Walsh, Gary Biopharmaceuticals Biochemistry and Biotechnology (2 ed, John Wiley \& Sons Ltd., Chichester, 2003).

World Bank Intellectual Property Protection, Foreign Direct Investment, and Technology Transfer: Discussion Paper (World Bank, Washington DC, 1994). 


\section{Journals}

Adams, Christopher P and Van V Brantner "Estimating the Cost of New Drug Development: Is it really \$802 Millions?” (2006) Health Affairs 25(2) 420.

Adelman, Martin J and Sonia Baldia "Prospects and Limits of the Patent Provision in the TRIPS Agreement: The Case of India” (1996) 29 Vand J Transnat'1 L 507.

Archana, Roy, Sajeev Chandran and Lokesh Jain "Implication of New Patent Regime on Indian Pharmaceutical Industry: Challenge and Oppertunities" (2005) 10 Journal of Intellectual Property Rights 269.

Baker, Mark B "Awakening the Sleeping Giant: India and Foreign Direct Investment in the $21^{\text {st }}$ Century" (2005) 15 Ind Int'l \& Comp L Rev 389.

Basheer, Shamnad "India's Tryst with TRIPS: The Patents (Amendment) Act 2005" (2005) 1 The Indian Journal of Law and Technology 16.

Basheer, Shamnad "India's New Patent Regime: Aiding "Access" or Abetting "Genericide"? (2007) 9(2) International Journal of Biotechnology 122.

Basheer, Shamand and Prashant Reddy "Ducking" TRIPS in India: A Saga Involving Novartis and the Legality of Section 3(d) (2008) 20 (2) National Law School of India Review, 132.

Bernard, Pe`coul "Access to Essential Drugs in Poor Countries: a Lost Battle? (1999) 281(4) Jama 361.

Bhatt, Tina S “Amending TRIPS: A New Hope for Increased Access to Essential Medicines” (2007-2008) 33 Brook J Int'l L 597.

Bhattacharya, Bhaskar and Parama S Palit, "Does Intellectual Property Laws in Indian and China Encourage Innovation?” (2008) 4(3)日本知財学会誌 [Journal of Intellectual Property Law of Japan] 82.

Bohrer, Robert A "Reach-Through Claims for Drug Target Patents: Rx for Pharmaceutical Policy" (2008) 26(1) Nature Biotechnology 55.

Bower, Jane D and Julian C Sulej "The Indian Challenge: The Evolution of a Succesful New Global Strategy in the Pharmaceuticlka Industry" (2007) 19(5) Technology Analysis \& Strategic Management 611.

Braga, Carlos Alberto Primo "The Economics of Intellectual Property Rights and the GATT: A View from the South" (1989) 22 Vand J Transnat'1 L 243.

Bruce, Lindsay (Guest Editorial) "Defending Value and Maximising Profitability of Innovative Pharmaceuticals Over Their Entire Life Cycles" (2003) 3(3) International Journal of Medical Marketing 195. 
Cambell, Randy L "Global Patent Law Harmonization: Benefits and Implementation" (2003) 13 Ind Int'1 \& Comp L Rev 605.

Carolanne, Dai and Tomas J Philipson "Between - vs Within -Patent Competition" (2003) Regulation 42.

Chadha, Alka "Destination India: The Right Choice for the Pharmaceutical Industry" (2006) 7(1) Delhi Business Review 1.

Chaisse, Julien L and Samira Guennif "Patent Political Economy - Indian Lessons on Pharmaceutical Patent” (2006) 1902 Bepress Legal Series 3.

Chataway, Joanna, Dinar Kale and David Wield (editorial) "The Indian Pharmaceutical Industry Before and After TRIPS" (2007)19(5) Technology Analysis \& Strategic Management 559.

Chataway, Joanna, Joyce Tait and David Wield "Frameworks for Pharmaceutical Innovation in Developing Countries - The Case of Indian Pharma" (2007) 19(5) Technology Analysis \& Strategic Management 697.

Chataway, Joanna, Kalpana Chaturvedi and David Wield "Policy, Markets and Knowledge: Strategic Synergies in Indian Pharmaceutical Firms"(2007) 19(5) Technology Analysis \& Strategic Management 565.

Collins-Chase, Charlest T "The Case Against TRIPS-Plus Protection in Developing Countries Facing AIDS Epidemics" (2007-2008) 29 U Pa J Int'l L 763.

Comanor, William S and John Z Lu "Strategic Pricing of New Pharmaceuticals" (1998) 80 The Review of Economics and Statistics 108.

Cordray, Monique L “GATT V. WIPO“(1994) 76 Journal of Patent and Trademark Office Society 121.

Correa, Carlos M “Trends in Technology Transfer - Implications for Developing Countries (1994) 21 Science and Public Policy 369.

Cuenot, Kevin "Perilous Potholes in the Path toward Patent Law Harmonization" (1997) 11 JL \& Pub Pol'y 101.

Dean, Sierra "India's Controversial New Patent Regime: The End of Affordable Generics?” (2006) 40 Int'l Law 725.

Dettmann, Jean M "GATT: An Opportunity for an Intellectual Property Rights Solution" (1991) 4 The Transnat'l Law 347.

Dickson, Michael and Jean Paul Gagnon "The Cost of New Drug Discovery and Development" (2004) 4(22) Discovery Medicine 172.

DiMasi, Joseph A and Henry G Grabowsky "The Cost of Biopharmaceutical R\&D: Is Biotech Different?" (2007) 28 (4-5) Managerial and Decision Economics 469. 
DiMasi, Joseph A and Kenneth I Kaitin "Measuring the Pace of New Drug Development in the User Fee Era" (2000) 34 Drug Information Journal 673.

DiMasi, Joseph A, Ronald W Hansen and Henry G Grabowski "The Price of Innovation: New Estimates of Drug Development Costs" (2003) 22 Journal of Health Economics 151.

Dominguez, Beatriz, Juan-Jose Ganuza and Gerard Llobet "R\&D in the Pharmaceutical Industry: a World of Small Innovations" (2009) 55(4) Management Science 539.

Duffy, John F “Harmony and Diversity in Global Patent Law” (2002) 17 BTLJ 685.

Eisenberg, Rebecca S “The Problem of New Uses” (2005) 2 Yale J Health Pol'y L \& Ethics 717.

Eisenberg, Rebecca S and Michael M Heller "Can Patents Deter Innovation? The Anticommons in Biomedical Research" (1998) 280 Science 698.

Emmert, Frank "Intellectual Property in the Uruguay Round - Negotiating Strategies of the Western Industrialised Countries” (1989-1990) 11 Mich J Int'l L 1317.

Ford, Sara M "Compulsory Licensing Provisions under the TRIPS Agreement: Balancing Pills and Patents (2000) 15 Am U Int'l L Rev 941.

Garrett, Hardin "The Tragedy of the Commons" (1968) Science 162 (3859)1243.

Grabowski, Henrey G and John Vernon "The Distribution of Sales Revenues from Pharmaceuticals Innovation" (2000) 18(1) Pharmacoeconomics 21.

Grabowski, Henry G and Margaret Kyle "Generic Competition and Market Exclusivity Periods in Pharmaceuticals" (2007) 28 Managerial and Decision Economics 491.

Harrelson, John A “TRIPS, Pharmaceutical Patents, and the HIV/AIDS Crisis: Finding the Proper Balance between Intellectual Property Rights and Compassion (2001) 7 Widener L Symp J 175.

Heller, Michael "The Tragedy of the Anticommons: Property in the Transition from Marx to Markets" (1998) 111(3) Harv L Rev 621.

Henry, David and Joel Lexchin "The Pharmaceutical Industry as a Medicine Provider" (2002) 360 The Lancet 1590.

Heywood, Mark and Bebe Loff, "Patents on Drugs: Manufacturing Scarcity of Advancing Health?" (2002) 30 Journal of Law, Medicine \& Ethics 621.

Hindman, David "The Effect of Intellectual Property Regimes on Foreign Investment in Developing Countries" (2006) 23 Ariz J Int'l \& Comp L 467.

Hughes, Justin "The Philosophy of Intellectual Property" (1988) 77 Geo LR 287. 
Hutt, Peter Barton "The Importance of Patent Term Restoration to Pharmaceutical Innovation“(1982)1(2) Health Affair 6.

Ippolito, Roberto "Private Equity in China and India" (2007) 10(4) Journal of Private Equity 36.

Jeong-Yeon, Lee and Edwin Mansfield "Intellectual Property Protection and US Direct Investment” (1996) 78(2) Review of Economics and Statistics 181.

Kale, Dinar and Steve Little "From Imitation to Innovation: The Evolution of R\&D Capabilities and Learning Processes in the Indian Pharmaceutical Industry (2007) 19(5) Technology Analysis \& Strategic Management 589.

Koveos, Peter E amd Linghui Tang "China and India: A Tale of Two Entrepreneurial Giants" (2007) 12(4) Journal of Development Entrepreneurship 377.

Kunz-Hallstein, Hans Peter "The United States Proposal for a GATT Agreement on Intellectual Property and the Paris Convention for the Protection of Industrial Property (1989) 22 Vand J Transnat'l L 265.

Lai, Edwin "International Intellectual Property Rights Protection and Rate of Propduct Innovation (1998) 55 (1) Journal of Development Economics 133.

Lemley, Mark A and Kimberly A Moore "Ending Abuse of Patent Continuations" (2004) 84 BUL Rev 63.

Luna, Joseph “A matter of Time: India's Emerging Economic Prowess" (2006) 27 (4) Harv Int'1 Rev 36.

Mansfield, Edwin "Patents and Innovation: An Empirical Study" (1986) 32(2) Management Science 173.

Maskus, Keith E "Intellectual Property Challenges for Developing Countries: An Economic Perspective (2001) U Ill L Rev 457.

Mossinghoff, Gerald J "Research-Based Pharmaceutical Companies: the Need for Improved Patent Protection Worldwide “(1987) 2 JL \& Tech 307.

Mueller, Janice M "The Tiger Awakens: The Tumultuous Transformation of India's Patent System and the Rise of India Pharmaceutical Innovation" (2007) 68 U Pitt L Rev 491.

Omer, Assad "Access to Medicines: Transfer of Technology and Capacity Building (2001-2002) 20 Wis Int'l LJ 551.

Pazderka, B and K Stegemann "Pharmaceutical Innovation as a Collective Action Problem: An Application of the Economic Theory of Alliances" (2005) 8(2) Journal of World Intellectual Property 157. 
Ragavan, Srividhya "Of the Inequals of the Uruguay Round" (2006) 10 Marquette Intell Prop L Rev 273, 301.

Rai, Rajnish Kumar "Effect of the TRIPS-Mandated Intellectual Property Rights on Foreign Direct Investment in Developing Countries: A Case Study of the Indian Pharmaceutical Industry" (2009) 11(5) Journal of World Intellectual Property 404.

Rai, Rajnish Kumar "Patentable Subject Matter Requirements: An Evaluation of Proposed Exclusions to India's Patent Law in Light of India's Obligation under the TRIPS Agreement and Options for India" (2008) 8 Chi-Kent J Intell Prop 41.

Rao, P M "The Emergence of the Pharmaceutical Industry in the Developing World and its Implications for Multinational Enterpeise Strategies" (2008) 2 (2) International Journal of Pharmaceutical and Healthcare Marketing 103.

Resnik, David B "Developing Drugs for the Developing World: An Economic, Legal, Moral, and Political Dilema" (2001) 1(1) Developing World Bioethics 12.

Scherer, Frederic M "The Pharmaceutical Industry - Prices and Progress" (2004) 351(9) The New England Journal of Medicine 927.

Sell, Susan K "Intellectual Property as a Trade Issue: From the Paris Convention to GATT” (1989) 13 Legal Stud F 407.

Shamnad, Basheer T and Prashant Reddy "The "Efficacy" of Indian Patent Law: Ironing Out the Creases in Section 3(d)" (2008) 5(2) Scripted 232.

Sherwood, Robert M "The TRIPS Agreement: Implications for Developing Countries" (1996-1997) 37 Idea 491.

Singham, Shanker A "Competition Policy and the Stimulation of Innovation: TRIPS and the Interface between Competition and Patent Protection in the Pharmaceutical Industry" (2000) 26 Brook J Int'l L 363.

Tomar, David K "A Look into the WTO Pharmaceutical Patent Dispute between the United States and India” (1999) 17 Wis Int'1 LJ 579,592.

Trouiller, Patrice and others "Drug Development for Neglected Diseases: A Deficient Market and a Public-Health Policy Failure" (2002) 359 (9324) The Lancet 2188.

Tully, Danielle L "Prospects for Progress: The TRIPS Agreement and Developing Countries after the Doha Declaration" (2003) 26(1) BC Int'l \& Comp L Rev 129.

Viswanathan, Aparna "From Commanding Heights to Competition: A Comparative Analysis of India's Competition Act 2002 with UK/EC Law" (2003) 14(7) Int'1 Company \& Com L Rev 229.

Weissman, Robert "A Long Strange TRIPS: The Pharmaceutical Industry Drive to Harmonize Global Intellectual Property Rules, and the Remaining WTO Legal Alternatives Available to Third World Countries" (1996) 17 U Pa J Int'l Econ L 1069. 
Whobrey, Brittany "International Patent Law and Public Health: Analyzing TRIPS' Effect on Access to Pharmaceuticals in Developing Countries" (2006-2007) 45 Brandeis LJ 623.

Wilson, Clark A D "The TRIPS Agreement: Is It Beneficial to the Developing World, or Simply a Tool Used to Protect Pharmaceutical Profits for Developed World Manufactures" (2005) 10 J Tech L \& Pol'y 243.

\section{Unpublished seminars and papers presented at conferences}

Arcuri, Allesandra and Rosa Castro "How Innovative Is Innovative Enough?

Reflections on the Interpretation of Article 27 TRIPS from Novartis v Union of India" (2008 Inaugural Conference of the Society of International Economic Law, Geneva, 15-17 July 2008).

DiMasi, Joseph A "A Price Trends for Prescription Pharmaceuticals: 1995-1999" (A Background Report Prepared for the Department of Health and Human Services Conference on Pharmaceutical Pricing Practices, Utilization and Costs, Washington DC, 8-9 August 2000).

Kyle, Margaret K and Anita M McGahan "Investments in Pharmaceuticals Before and After TRIPS" (Entrepreneurship and Innovation - Organizations, Institutions and Regions, Copenhagen, 2008).

\section{Thesis}

AlAzzawi, Shireen "Foreign Direct Investment and Knowledge Inflows: Evidence from Patent Citations" (Research paper, University of California, Davis, 2004).

Chaudhuri, Supid "Is Product Patent Protection Necessary in Developing Countries for Innovation? R\&D by Indian Pharmaceutical Companies after TRIPS" (Working paper, Indian Institute of Management Calcutta, 2007).

Dreyfuss, Rochelle C "Patents and Human Rights: Where is the Paradox?" (Law and Economics Research Paper, New York University School of Law, 2007).

Dreyfuss, Rochelle C "The Role of India, China, Brazil and Other Emerging Economies in Establishing Access Norms for Intellectual Property and Intellectual Property lawmaking" (Institute for International Law and Justice, Working Papers, New York University School of Law, 2009).

Garai, Prantik "Patent Amendment Act 2005: Its Effect on Indian Pharmaceutical Company" (Working paper, West Bengal National University of Juridical Sciences, 2009).

Garde, Tanuja V “India's Intellectual Property Regime: A Counterbalance to Market Liberalization?" (Working paper, Stanford University, 2009). 
Lanjouw, Jean O "The Introduction of Pharmaceutical Product Patents in India: Heartless Exploition of the Poor and Suffering?" (Center Discussion Paper, Yale University Connecticut, August 1997) 1.

Matthews, Duncan "Intellectual Property Rights, Human Rights and the Right to Health"(Legal Studies Research Paper No 24/2009, Queen Mary University of London, 2009).

Sampath, Padmashree Gehl "India's Pharmaceutical Sector in 2008, Emerging Strategies and Global and Local Implications for Access to Medicine" www.dfid.gov.uk (accessed 20 September 2009).

Shamand, Basheer "Limiting the Scope of Pharmaceutical Patents and MicroOrganisms: A TRIPS compatibility Review" (Research Paper, University of Oxford, 2005).

Smarzynska, Beata K "Composition of Foreign Direct Investment and Protection of Intellectual Property Rights: Evidence from Transition Economies”(Working Paper, Yale University, 1999) 1.

\section{Conferences}

The Israel Life Science Industry - Biological and Medical Conference and Exhibition 2009 [ILSI-BIOMED].

\section{Non-academic journals and periodicals}

Beinhocker, Eric D and Adil S Zainulbhai "Tracking the Growth of India's Middle Class" (August 2007) The Mckinsey Quarterly 51.

Bernstein, William J "Fast Economies, Elusive Returns” (August 2009) Money 58.

Changes to Foreign Investment (April 2009) International Financial Law Review.

Mehrotra, N. N "Patents Act and Technological Self-Reliance: The Indian Pharmaceutical Industry" (1989) Economic and Political Weekly 1059.

\section{International Material}

\section{Declarations, agreements and treaties}

Declaration on the TRIPS Agreement and Public Health (14 November 2001).

Paris Convention for the Protection of Industrial Property revised at Stockholm, July 14, 1967.

Patent Cooperation Treaty 1970.

Patent Law Treaty 2000. 
The Universal Declaration of Human Rights 1948.

Trade-Related Intellectual Property Rights Agreement (15 April 1994).

2. Organisations amd jurisdictions

(a) Resolutions and legislations

- European Union:

Council Commission 2007/C Charter of Fundamental Rights of the European Union [2007]

Directive 2004/27/EC of the European Parliament and of the Council of 31 March 2004 amending Directive 2001/83/EC on the Community Code Relating to Medicinal Products for Human Use [2004] OJ L 136/ 34.

- United Nations:

UNHCHR International Covenant on Civil and Political Rights Adopted and opened for signature, ratification and accession by General Assembly Resolution 2200A (XXI) (16 December 1966).

(b) Cases

- World Trade Organization:

Canada - Patent Protection for Pharmaceutical Products, Report of the Panel (17 March 2000).

(c) Documents

- Organisation for Economic Co-operation and Development (OECD)

OECD Trade Committee The Impact of Trade Related Intellectual Property Rights on Trade and Foreign Direct Investment in Developing Countries (28 May 2003).

- United Nations:

UNAIDS/WHO 2008 Report On The Global AIDS Epidemic (WHO, Geneva, 2008).

UNCTAD-ICTSD "Encouraging International Technology Transfer" (May 2004) Issue Paper No. 7.

UN Commission on Human Rights "Economic, Social and Cultural Rights: The Impact of the Agreement on Trade-Related Aspects of Intellectual Property Rights on Human Rights" (27 June 2001).

UN Department of Economics and Social Affairs The Role of the Patent System in the Transfer of Technology to Developing Countries (United Nations, New York, 1974). 
UN Economic and Social Committee General "The Right to the Highest Attainable Standard of Health (Article 12 of the International Covenant on Economic, Social and Cultural Rights) (11 August 2000).

UN Sub - Commission on the Promotion and Proteciotn of Human Rights "Intellectual Property Rights and Human Rights" (17 August 2000).

- World Health Organization

WHO Commission on Macroeconomics and Health Differentiated Pricing of Patented Products (Working Paper No 63 Revised, New Delhi, 2001).

WHO World Health Assembly Global Strategy and Plan of Action on Public Health, Innovation and Intellectual Property (WHA61.21, Geneva, 2008).

WHO World Health Assembly Public Health, Innovation, Essential Health Research and Intellectual Property Rights: Towards a Global Strategy and Plan of Action (WHA59.24, Geneva, 2006).

WHO World Malaria Report 2008 (WHO, Geneva, 2008).

WHO Report 2007 Global Tuberculosis Control: Surveillance, Planning, Financing (WHO, Geneva, 2008).

- World Trade Organization:

WTO General Council Implementation of Paragraph 6 of the Doha Declaration on the TRIPS Agreement and Public Health (WT/L/540 and Corr 1, Geneva, 2003).

\section{Electronic sources}

Adamos, Adamou and Subash Sasidharan "The Impact of R\&D and FDI on Firm Growth in Emerging - Developing Countries: Evidence from Indian Manufacturing Industries" (2007) www.papers.ssrn.com (accessed 8 January 2009).

Aditi, Bajaj K R, and Swastik Nigam "Globalization in the Indian Pharmaceutical Industry - FDI Spillovers and Implications on Domestic Productivity: 1991-2007” (2008) www.insightory.com (accessed 20 January 2009).

Arvind, Singhatiya, "Impact of Product Patent on FDI in Indian Pharmaceutical Industry" http://ezinearticles.com (accessed 18 January 2009).

Asia Pacific to Replace United States and Europe as Pharmaceutical Industry Powerhouse www.primenewswire/newsroom/news (accessed 3 September 2009).

Avalere Health LLC www.avalerehealth.net (23 October 2009).

Bayer www.bayer.com (accessed 11 October 2009). 
Biswajit, Dhar and K M Gopakumar "Post-2005 TRIPS Scenario in Patent Protection in the Pharmaceutical Sector: The Case of the Generic Pharmaceutical Industry in India" (2006) www.measwatch.org (13 September, 2009).

Bristol-Myers Squibb www.bms.com/pages/default.(accessed 31 January 2009).

Burrell, Sarah E and Gary C Messplay "Implications of FDAAA 2007 Changes are A foot Following the FDA's Reauthorization" www.fda.gov (accessed 20 September, 2009).

Capgemini "Report Finds the Growth of New Multinationals from Emerging Markets Challenges Drug Prices and Affordability www.ideas.repec.org (accessed 1 August 2009).

Carsten, Fink "How Strong Patnet Protection in India Might Affect the Behaviour of Transnational Pharmaceutical Industries" (2000) www.papers.ssrn.com (accessed 18 November 2008).

Chatterjee, Sourav and others "Intellectual Property Rights in Developing Nations" www.iipi.org (accessed 31 January 2009).

Chaudhuri, Shubham, Pinelopi Goldberg and Panle Jia "Estimating the Effects of Global Patent Protection in Pharmaceuticals: A Case Study of Quinolones in India" (2004) www.nber.org (accessed 24 September 2009).

Cipla www.cipla.com/home (accessed 16 August 2009).

Clinical Cancer Advances 2008: Major Research Advances in Cancer Treatment, Prevention and Screening (2008) www.cancer.net (accessed 17 March 2009).

Competition in the Pharmaceutical Marketplace (2002) www.ftc.gov (accessed 11 November 2008).

Conducting a Clinical Safety Review of a New Drug Product Application and Preparing a Report on the Review www.fda.gov (accessed 4 September, 2009)

Corrado, Nicholas and Katherine C Linton "A "Calibrated Approach": Pharmaceutical FDI and Evolution of the Patent Law in India” (2007) www.papers.ssrn.com (accessed 31 January 2009).

Country Classification http://go.worldbank.org/K2CKM78CC0 (accessed 1 September 2009).

Dr Reddy's www.drreddys.com/aboutus/aboutus (accessed 29 August 2009).

Drug Firm to Cut Prices to 50 Poorest Nations - Report www.nzherald.co.nz (accessed 16 February 2009).

Eli Lilly www.lilly.com (accessed 31 January 2009). 
A report by the EU working Group on Pharmaceuticals and public health noted in its 28 March 2000 report to the High-level Committee on health for policies and Actions in the framework of the EU treaty of Amsterdam www.ec.europa.eu/health/ph_ overview/ Documents/ke02_en (30 October 2009).

Facts and Myths about Generic Drugs www.fda.gov (accessed 8 October 2008).

Garnier, Jean Pierre, Head of Glaxo, Special AIDS Report www.guardian.co.uk/aids.

Gautam, Kumara, Plalash Mitra and Chandrika Pasricha " 2015: Unlocking the Potential of the Indian Pharmaceuticals Market" (2007) www.mckinsey.com (accessed 17 October 2009).

GlaxoSmithKlin www.gsk.com (accessed 31 January 2009).

Glenmark Pharmaceuticals Ltd www.glenmarkpharma.com/about/index (accessed 29 August 2009).

Glivec Patent Case in India: Fact vs. Fiction www.novartis.com (accessed 8 November 2009).

Global Health Fellows www.pfizer.com (accessed 01 October 2009).

Global Public Policy Issues, GlaxoSmithKline's Position "Incremental Innovation" www.gsk.com (accessed 2 February 2009).

GVK Biosciences Inc. www.gvkbio.com (accessed 31 January 2009).

Hetero Drugs Ltd www.heterodrugs.com (accessed 16 August 2009).

HIV/AIDS - 20 Years of Progress www.innovation.org (accessed 18 November 2008).

Indian Intellectual Property Appellant Board www.ipab.it.nic.in (accessed 13 October 2009).

Lichtenberg, Frank R "The Expanding Pharmaceutical Arsenal in the War on Cancer" (2004) www.nber.org (accessed 18 November 2008).

Lippoldt, Douglas "Intellectual Property Rights, Pharmaceuticals and Foreign Direct Investment" (2006) www.gem.sciences (accessed 11 November 2008).

Lupin www.lupinworld.com (accessed 31 January, 2009).

Mathiyazhagan, Maathai K and Dukhabandhu Sahoo "Do Foreign Direct Investment Inflows Benefit the Major Sectors in India?" (2008) 38 Institute of South Asian Studies www.isas.nus.edu.sg (accessed 13 April 2009).

Medical Dictionary Online www.thefreedictionary.com (accessed 13 October 2009). 
Mendonca, Cardoso de, Mario Jorge and Marcelo Jose Braga Nonnenberg "The Determinants of Direct Foreign Investment in Developing Countries" (2004) www.anpec.org.br/encontro2004/artigos/A04A061 (accessed 30 August 2009).

Merck www.merck.com (accessed 31 January, 2009).

Merck \& Co, Inc Publishes 2008 Global Corporate Responsibility Report, Merck Says Good Corporate Citizenship and Governance Have Never Been More Important www.merck.com (accessed 1 October 2009).

Merck and QIAGEN Collaborate to Accelerate Access to Cervical Cancer Vaccination and Screening in Developing Countries www.merck.com (accessed 1 October 2009).

Nicholas Piramal India Limited www.nicholaspiramal.com (accessed 29 August 2009).

Novartis www.novartis.com (accessed 08 November 2008).

Novaris Challenges Gleevec Patent Rejection in the Supreme Court www.lawyerscollective.org/node/1042 (14 October 2009).

Novartis Marks 20-Year Commitment in the Fight against Leprosy www.novartis.com (accessed 01/10/09).

Oxford English Dictionary Online, http://dictionary.oed.com (accessed 02 February, 2009).

Paris Convention Contracting Parties www.wipo.int/treaties/en/ip/paris/ (accessed 10 December, 2008).

Paris Notification No188 Paris Convention for the Protection of Industrial Property Accession by the Republic of India www.wipo.int/edocs/notdocs/paris/treaty_paris_188 (accessed 4 April 2009).

Patent Cooperation Treaty Notification No. 129 Accession by the Republic of India www.wipo.int/treaties (accessed 4 April 2009).

Pfizer Investment in Health www.pfizer.com (accessed 01 October 2009)

Pharma Revenue Struggles as Patents Expire www.businessday.co.nz (accessed 18 November 2008).

Pharmacoevolution: The Advantages of Incremental Innovation www.who.int/intellectualproperty/submissions (accessed 2 February 2009).

Profile 2008 Pharmaceutical Industry (2008) IV, 4 www.amsa.org/business/2008Profile_(accessed 11 November 2008).

Protection and Enforcement www.wto.org (accessed 29 March 2009). 
Qiagen N V www.qiagen.com (acceded 17 October 2009).

R\&D Spreads Out www.fdimagazine.com (accessed 23 January 2009).

Ranbaxy www.ranbaxy.com (accessed 31 January 2009).

Roche www.roche.com (accessed 14 October 2009).

Shanti, Kumar, Nitin Shukla and Tanushree Sangal "Evergreening of Patents and the Indian Patent Law" (2009) www.papers.ssrn.com (accessed 09 September 2009).

South Centre www.southcentre.org (accessed 26 October 2009).

Sun pharmaceutical Industries Ltd. www.sunpharma.com (accessed 31 January, 2009).

The Food and Drug Administration [FDA] www.fda.gov/cder/dsn/factsheet (accessed 8 October 2008).

The Impact of India's Amended Patents Act to Access to Affordable HIV Treatment www.healthgap.org (accessed 1 October 2009).

The Importance of Incremental Innovation for Development (2005) www.iccwbo.org (accessed 2 February 2009).

The Story of Glivec www.innovaiton.org (accessed 08 November 2008).

The World Bank www.worldbank.org (accessed 1 September 2009).

The World Trade Organisation www.wto.org (accessed 20 November 2008).

The WTO General Council www.wto.org (accessed 18 November 2009).

Trade and Foreign Direct Investment www.wto.org (accessed 8 January, 2009).

Wellcome Trust and Merck Launch First of Its Kind Joint Venture to Develop Affordable Vaccines for Low-Income Countries www.merck.com (accessed 01/10/09).

What is the WTO? www.wto.org (accessed 17 October 2009).

Wyeth www.wyeth.com (accessed 2 February 2009).

X-rates.com www.x-rates.com (accessed 18 October 2009).

Zyduscadila www.zyduscadila.com (accessed 31 January, 2009). 


\section{E. Table of cases and decisions of statutory tribunals}

- India

Novartis AG v Adarsh Pharma (28 April 2004) Mad HC O.A NOs. 13 to 17/ 2004 and A. NOs. 841 to 849, 1076 and 1218/2004 in C S NOs 5 to 9 of 2004.

Novartis AG v Mehar Pharma (23 December 2004) Bom HC Notice of Motion No. 293 of 2004 in Suit No 261 of 2004.

Novartis AG v Union of India and Others [2007] MDH W P No 24759/06 and W P No 24760/06 (HC Madras).

Novartis AG v Union of India (26 June 2009) Intellectual Property Appellate Board M P Nos 1 to 5/2007 in TA/1 to 5/2007/PT/CH, M P No 33/2008 IN TA/1/2007/PT/CH, TA/1 TO 5/2007/ PT/CH.

Patent Application 1602/MAS/98 Indian Controller General of Patents Designs and Trademarks (14 October 2005).

Roche v Cipla Ltd (19 March 2008) ND HC I A 642/2008 in CS (OS) 89/2008.

Roche v Cipla Ltd (24 April 2009) FAO (OS) 188/2008 .

- New Zealand

Pharmaceutical Management Agency v Commissioner of Patents [2000] 2 NZLR 529.

Wellcome Foundation Ltd v Commissioner of Patents [1983] NZLR 385 (CA).

- United States

Aventis Pharma Deutschland Gmbh and King Pharmaceuticals v Lupin Ltd and Lupin Pharmaceuticals Inc (2007) 499 F 3d 1293 (Fed Cir).

eBay, Inc v MercExchange (2006) 126 S Ct 1837.

F Hoffmann-La Roche Ltd and ANR v Cipla Ltd (24 April 2009) FAO (OS) 188/2008.

KSR International Co v Teleflex Inc et al (2007) 165 L Ed 705.

Pfizer Inc v Apotex Inc (2007) 480 F 3d 1348 (Fed Cir) en banc.

Roche Products, Inc v Bolar Pharmaceutical Co (1984) 733 F 2d 858 (Fed Cir). 